\title{
At The Interface
}

cutting- $\epsilon$ dge Research

\section{Villains}

Global Perspectives on Villains and Villainy Today

Edited by

Burcu Genc \& Corinna Lenhardt

$$
\begin{gathered}
\text { Inter-Disciplinary Press } \\
\text { Publishing Creative Research }
\end{gathered}
$$


Villains 


\title{
A t the I nterface
}

\author{
Series Editors \\ Dr Robert Fisher \\ Dr Daniel Riha
}

\section{Advisory Board}

Dr Alejandro Cervantes-Carson

Professor Margaret Chatterjee

Dr Wayne Cristaudo

Mira Crouch

Dr Phil Fitzsimmons

Professor Asa Kasher

Owen Kelly
Dr Peter Mario Kreuter Martin McGoldrick Revd Stephen Morris Professor John Parry Paul Reynolds

Professor Peter Twohig Professor S Ram Vemuri

Revd Dr Kenneth Wilson, O.B.E

An At the Interface research and publications project. http://www.inter-disciplinary.net/at-the-interface/

The Evil Hub

'Villains and Villainy'

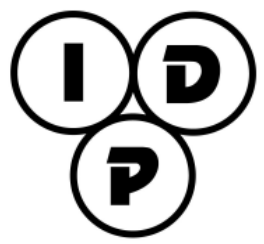

2011 


\title{
Villains: \\ Global Perspectives on Villains and Villainy Today
}

\author{
Edited by
}

Burcu Genc \& Corinna Lenhardt

Inter-Disciplinary Press

Oxford, United Kingdom 


\section{(C) Inter-Disciplinary Press 2011 http://www.inter-disciplinary.net/publishing/id-press/}

The Inter-Disciplinary Press is part of Inter-Disciplinary.Net - a global network for research and publishing. The Inter-Disciplinary Press aims to promote and encourage the kind of work which is collaborative, innovative, imaginative, and which provides an exemplar for inter-disciplinary and multi-disciplinary publishing.

All rights reserved. No part of this publication may be reproduced, stored in a retrieval system, or transmitted in any form or by any means without the prior permission of Inter-Disciplinary Press.

Inter-Disciplinary Press, Priory House, 149B Wroslyn Road, Freeland, Oxfordshire. OX29 8HR, United Kingdom.

+44 (0)1993882087

ISBN: 978-1-84888-0052-8

First published in the United Kingdom in eBook format in 2011. First Edition. 


\section{Table of Contents}

Introduction

ix

Burcu Genc \& Corinna Lenhardt

\section{Part I: $\quad$ Renaissance Villainy}

An Archetypal Figure of the 'Villainous Jew' in

English Renaissance Literature

Ivona Misterova

The Strategies of Narrative Representation of Villains

in English Renaissance Rogue Literature

Kateryna Vasylyna

Damnation of a Hero or Villain: Christopher Marlowe's 21

The Tragical History of the Life and Death of

Doctor Faustus

Seyda Inceoglu

\section{Part II: Doubles, Criminals and Nicholas Dyer}

A Complicated Matter of Villainy: Mr Hyde in R. L.

Stevenson's 'The Strange Case of Dr Jekyll and Mr Hyde' Ömer $\ddot{O} \breve{G} \ddot{U} N C ̧$

What is a Villain? Thackeray's Play with the Reader's

Perception in Catherine and Barry Lyndon

Ellen Redling

The Double in Poe and Dostoevsky: The Descent

into the Subconscious

Ekaterina Yasko

Steerpike and Evasive Villainy in Mervyn Peake's

Gormenghast Novels

Arrate Hidalgo Sánchez

Enter Peter Ackroyd's Nicholas Dyer: Architect,

Devil Worshipper and Murderer

Roxanne Barbara Doerr 
Washington's Troops Skinned Dead Indians from the

Waist Down and Made Leggings from the Skins:

Reiterating Villainy in Native American

Gothic Fiction

Corinna Lenhardt

Representations of Villainy in Yemeni Fiction

Fawaz Jazim

A Spanish Incarnation of Cain: Miguel de Unamuno's

Abel Sánchez

Santiago Pérez Isasi

\section{Part IV: $\quad$ Gendered Villainy}

The Changing Face of the Femme Fatale: Is She

Really Villainous?

Burcu Genc

The Portrayal of the Male Villain in the Broadcast

Televisual Text Hollyoaks

Selina E. M. Doran

Monstrous Action-Men and Jealous Princesses:

Defining the Villain in Gendered Narratives

Dikmen Yakall-Çamoğlu

Part V: $\quad$ Villains of Our Youth

The Triumvirate of Evil: Major Villains of Don Rosa's

Donald Duck Comics

Katja Kontturi

I Want More! Insatiable Villains in Children's

Literature and Young Adults' Fiction

Karin Kokorski

Part VI: $\quad$ Villainy On Stage and On-Screen

'Gainst Nature Still: Reading Macbeth's

Murder of Duncan

Timo Uotinen 
Precious Villain ... Honourable Murderer:

The Betrayer as Scapegoat in Shakespeare

Shala Alert

The Sow that Repeatedly Devours Her Piglets:

The Villain on the Nigerian Stage

Tiziana Morosetti

You don't Make Up for Your Sins in Church:

Dilemmas of Moral Development in Scorsese's

Mean Streets

David Sousa

\section{Part VII: $\quad$ Futuristic Villains and Cosmic Killers}

The Mad Scientist as a Villain: H. G. Wells'

The Island of Dr. Moreau

Oya Bayıltmış

I Am the Man in the Dark Room: The Puppetmaster from Cosmic Adversary to Cosmic Villain

Luke Seaber

The Evolutionary Villain: Alfred Bester as an

Oppressed Victim and a Righteous Villain

Mikko Poutanen

The Cyborg Villain: Mechanical Hybridity and

Existential Fear

Jori De Coster

Part VIII: Villainous States

Sexual Villainy in the Holocaust

Beverley Chalmers

The State Villainy in Orwell's 1984 



\section{Introduction}

\section{Burcu Genc \& Corinna Lenhardt}

In the real world there are no villains. No one actually sets out to do evil. Yes, there are madmen and murderers and rapists and crooked politicians and greedy land developers and all sorts of villainous behaviors. But each of those people believes that he is doing what is necessary, and maybe even good. Every tyrant in history was convinced that he had to do the things he did for his own good and for the good of the people around him.

Fiction mirrors life. Or, more accurately, fiction serves as a lens to focus what we know of life and bring its realities into sharper, clearer understanding for us. There are no villains cackling and rubbing their hands in glee as they contemplate their evil deeds. There are only people with problems, struggling to solve them.

(Ben Bova, Tips for Writers)

Ben Bova, a contemporary American writer of fiction and non-fiction alike, certainly offers a clear-cut style sheet to pass on to the next generation of authors. Villains, Bova is convinced, belong solely to the realm of fiction - bad fiction that is. Real-life villains, in turn, do not exist and should not be made up artificially. True, one is inclined to answer, since the sinisterly cackling, leering, moustachetwirling and hand-rubbing black hat and his many villainous deeds have apparently not featured in the news lately. And true, too, if there was a novel featuring a badly composed bad guy like the one Bova has in mind, we would probably not be inclined to read and discuss it. Fortunately, hardly any author has ever not followed Bova's dictum.

There are villains in fiction and they are versatile and plain, cunning and clumsy, beautiful and ugly, black and white and green and red, and they have the potential to be the personification of pure evil; in other words, they show totally human characteristics. Villains blend in naturally with the environments from which they stem, while at the same time they stand out as the socially harmful 'Other', which needs to be contained and overcome for the sake of normality and life. Villainy, it seems, is a matter of perspective, a matter of 'us' versus 'them', 'normal' versus 'other', and 'life' versus 'death', but it is certainly not a matter of bad style.

The vital importance of the concept and the motif of 'villain' and 'villainy' for contemporary and past cultures around the world was explored and discussed in depth at the second global, interdisciplinary conference on 'Villains and Villainy' which was held at Oriel College, Oxford, in September 2010 as part of the research 
network Inter-Disciplinary.Net. Extraordinary scholars from around the world took the opportunity to share and discuss their insights into the subject from diverse backgrounds in numerous academic disciplines and research interests.

In order to provide a first-hand account of the conference proceedings, the presenters have submitted their original presentation scripts for this publication. For the same reason, editorial regulations and corrections within individual chapters have been kept to a minimum. We believe that providing an open forum for international scholars is of utmost importance for the advancement of theoretical approaches to villainy, even if this might entail inaccuracies of language. However, to facilitate a clearly structured presentation of the breadth and density of the scholarly projects and discussions in this volume, we have modified and broken down the original conference schedule into eight parts:

$\begin{array}{ll}\text { Part I } & \text { Renaissance Villainy } \\ \text { Part II } & \text { Doubles, Criminals and Nicholas Dyer } \\ \text { Part III } & \text { Literary Villainy with an Ethnic Twist } \\ \text { Part IV } & \text { Gendered Villainy } \\ \text { Part V } & \text { Villains of Our Youth } \\ \text { Part VI } & \text { Villainy Onstage and On-Screen } \\ \text { Part VII } & \text { Futuristic Villains and Cosmic Killers } \\ \text { Part VIII } & \text { Villainous States }\end{array}$

Parts I to $\mathrm{V}$ focus mainly on the manifold literary representations of villains and villainy, a tendency that can also be found in some of the other sections. However, the individual chapters all address very different approaches to the motifs, each perceiving the highly complex phenomenon through the unique lenses of various academic fields and philosophical backgrounds. Although the discussion of literature has been a central focus of the 2010 conference participants, the manifold findings concerning the motif strongly suggest the cultural relevancy of villains and villainy to all fields of cultural production and to human life in general.

In Part I we set out to envision villainy as an ever-changing yet surprisingly persistent literary motif through the ages and across cultures. Ivona Miseterova and Seyda Inceoglu pick up famous characters from the Renaissance period, while Kateryna Vasylyna aims at singling out the social and cultural phenomena that influenced the peculiar perception of crime and criminals in the English Renaissance. Vasylyna argues that a moral bias in attitude towards villainy was stipulated by the Renaissance outlook, as well as manneristic tendencies, and she places further emphasis on the evolution of the aesthetic of representation of villains and their activity. Misterova focuses on the male Jew as a villainous figure and discusses how Shakespeare creates a universal Jew-villain character with Shylock. Unlike her sources, Misterova argues that Shakespeare's Shylock cannot be dismissed as a one-dimensional evil character. Inceoglu points out the vague 
line between heroism and villainy. Her analysis of the motives of Dr Faustus emphasises the fact that his position is too ambiguous to define him clearly as a hero or a villain.

Part II deepens our understanding of literary villains and villainy by breaking down the intrinsically ambiguous notions further and further. With the Double as a cross-cultural, philosophical concept, Ekaterina Yasko introduces a motif that renders the traditional villain into a dramatically close and all too familiar enemy. In the wake of deconstructed normality in Poe and Dostoevsky, Yasko claims, we can witness the destruction of the very notion of the individual self. By drawing our attention to Robert Louis Stevenson's 'The Strange Case of Dr Jekyll and Mr Hyde' ÖMER ÖĞUUNÇ tests once again our ability to distinguish reliably between literary heroes and villains. As an appropriate representation of the late-Victorian struggle between rigid social norms and the expectations of conformity, the novella centres upon Mr Hyde who has been metaphorically instantiated as a villain by the same society that he now confronts violently. Just as Yasko and Inceoglu have shown before, any clear-cut definition of villainy crumbles quickly in the wake of social and cultural change. Ellen Redling aims at defining the villain in a realistic sense as opposed to sensational and morally acceptable terms. To do so, she analyses Thackeray's Catherine and Barry Lyndon by placing the competition of crime centre stage in order to eliminate the barrier of moral discussion. Arrate Hidalgo Sánchez explores the character Steerpike and his relation to villainy in the Gormenghast novels of Mervyn Peake. She argues that Peake's approach to Steerpike renders any modern definition of villainy applicable to him invalid.

Roxanne Barbara Doerr traces the steps of villainy in Peter Ackroyd's novel Hawksmoor. The novel's villain, Nicolas Dyer, who lives in the seventeenth century, DOERR argues, also has the qualities of villains living in preceding and following centuries. More fascinatingly, she can show that Dyer is such an outstanding villain that Hawksmoor, a detective in the 1980s, is subjected to his powers in the face of reoccurring homicides.

Part III continues the discussion of villainy in literature with a shift of perspective towards ethnic writing strategies. Corinna Lenhardt, Fawaz Jazim and Santiago Pérez Isasi focus on very different minorities and cultures, however, the powerful statement ethnic writers make by twisting dominant literary conventions appears to be a truly global phenomenon. Lenhardt introduces the racialised motif of the 'Savage Villain' in Native American Gothic fiction. No longer utilised by mainstream America only, Gothic villainy becomes the epitome of Native America's struggle for literary renegotiation and cultural recognition. Jazim examines the nature of villainy in Yemeni fiction by analysing The Hostage, a novel by Zayd mutee' Dammaj, and selected short stories by Mohammad Muthana. Arguing that Yemeni literature depicts the country's political regimes in terms of villainy, Jazim concludes that as villains regimes are oppressive and above all 'with respect to others and the rest of the world - they simply do not care'. The last 
chapter in this section explores the rewritten and renegotiated myth of Cain in Miguel de Unamuno's Abel Sánchez. Taking into account both the Biblical myth and Byron's adaptation, Pérez Isasi interprets Unamuno's dark novel as a subversive exploration on the topic of envy and on Spain's 'national sin'.

Part IV focuses on villains and villainy under the concept of gender. Burcu Genc aims to explore the most famous villainess, the femme fatale, and attains a definition of the femme fatale by comparing religious cult figures and their reflections in literature. Genc concentrates on how the femme fatale struggles to break her chains and fails to do so by confining herself to the social norms built on religion and late nineteenth-century scientific gender theories. Selina E. M. Doran is interested in the British soap opera Hollyoaks and draws attention to the young female audience and their reaction to male characters who commit rape. Doran's research shows that this certain group of young females believes that eventually evil deeds will be avenged and the wrongdoers punished and that evil can only be defeated by good. Dikmen Yakall-Çamoğlu explores how three- and four-year-old Turkish children perceive villainy in relation to their own narrative identities. $\mathrm{He}$ shows how popular culture represents men and women differently, and argues further that the differentiation causes distinct types of villains to be defined by men and women, which ultimately serves the patriarchy.

In Part V Katja Kontturi and Karin Kokorski remind us of the villains that have haunted us ever since our childhoods. Kontturi starts us off by tracing villainy in the sugar-coated Disney universe. She analyses the top three villains in Don Rosa's Donald Duck comics; the Beagle Boys, Magica DeSpell and Flintheart Glomgold - an insatiable 'Triumvirate of Evil' in the midst of childhood imagination. In the second chapter of this section, Kokorski picks up the motif of the insatiable villain in children's and young adult fiction. Though of an overall shadowlike and two-dimensional existence, the villain's insatiable thirst for power enables both the protagonist's evolution into a hero and the young reader's joy of hating the diehard evil.

Part VI extends the quest of villainy to the stage and screen. The first two articles of this part return to the English Renaissance and deal with Shakespeare's villainous characters. Timo Uotinen discusses the unnatural murder of Scottish King Duncan to reach the fact that Macbeth is a self-destructive villain. Uotinen argues that separation between nature and culture creates hostility toward life in which Macbeth's self-destructive nature lies. Shala Alert approaches Shakespearean villains with the notion of the scapegoat. Alert examines the scapegoat with biblical figures like Judas and Satan and concludes that human failings and flaws create the villain in Shakespeare's use of the redemptive narrative. Tiziana Morosetti takes up the same notion of the scapegoat and elaborates on the Nigerian drama. However, Morosetti emphasises how Nigerian playwrights, especially Femi Osofisan and Wole Soyinka, sympathise with the villainous characters they create; the real villain, we find out, is the villainous 
politics of the state. David Sousa brings a different approach to the notion of villainy by concentrating on apathetic characters in Mean Streets. Sousa's characters are quite indifferent to the values that are being imposed on them. Neither the rules of the mafia nor the social values blended with Catholicism appear to be of any importance. Sousa emphasises ethical theories as a means to explore how the alienation and the many walls, which the characters have built around themselves, make them appear villainous.

In Part VII Oya Bayltmış, Luke Seaber, Mikko Poutanen, and Jori De Coster explore futuristic worlds and cosmic villains, which, however, are not quite as distant from our lives today as we might want to believe. Bayltmiş analyses the motif of the mad scientist in H.G. Wells' dystopia The Island of Dr Moreau in terms of villainy. In an age of scientific revolutions and cultural change, a science unguarded by ethical considerations and empathy will not contribute to human development, but end up in sheer acts of atrocious villainy and madness. Seaber's chapter focuses on the 'puppetmaster' villain, i.e., a villain, who is in fact organising both sides of a struggle for his own ends. Taking the character of Sunday in Chesterton's The Man Who Was Thursday as a starting point, Seaber analyses the (mis)adaptation of the archetypal cosmic manipulator in later twentieth- and early twenty-first-century fiction and concludes: The worst thing about a cosmic antagonist is quite simply that he is cosmic and therefore removed from humanity; this in turn makes him more villainous than any human villain could possibly achieve. In stark contrast to the 'puppetmaster' villain, Poutanen centres his chapter on a character who seeks to resolve the total stalemate in which he finds himself trapped by any means necessary. Seeking to investigate intertwined victimhood and villainy through the employment of telepathy as a literary device in science fiction, Poutanen focuses on the sci-fi universe originally created by J. M. Straczynski. We learn that science fiction and its telepaths are not about the uncanny as such, but about the very human concept of 'other', and its very real linkages to the concept of evil. The borderline between 'us' and 'them', 'human' and 'other' is also of utmost importance in De Coster's chapter. She states that cyborg villains (such as Darth Vader or the Borg), just like any other form of human hybridity, embody anxiety, and are pure existential fear about the loss of humanity given shape. Cyborgs teach us a crucial lesson about what it means to be human in a western (post)modern society.

In Part VIII Beverley Chalmers and Cumhur Yllmaz Madran elaborate on the notion of villainy with regard to politics in historical and literary contexts. Chalmers asks critically who the real villain is and explores sexual villainy during the time of German National Socialism. To do so, she also draws our attention to the Nazi ideology which assumed the Jews to be sexually polluted and villainous. Madran elucidates the villainous state on a literary level with George Orwell's 1984 and elaborates on the positive and negative uses of dichotomic structures concerning instrumental rationality in terms of social progress. In his research, 
Madran reminds us of the importance of Hannah Arendt's The Origins of Totalitarianism for our understanding of villains and villainy. 



\section{PART I}

\section{Renaissance Villainy}





\title{
An Archetypal Figure of the 'Villainous Jew' in English Renaissance Literature
}

\author{
Ivona Misterova
}

\begin{abstract}
This chapter attempts to analyse specific aspects of the archetypal figure of the villainous Jew in English Renaissance literature. During the Tudor period, portrayals of Jewish protagonists usually mirrored stereotypical anti-Jewish discourse and anti-Semitic attitudes. Thus, with emphasis on Shakespeare's The Merchant of Venice, an archetype of the villainous Jew will be discussed in the context of relevant historical events and facts, e.g. Roderigo Lopez's case and the Jewish minority's status in England and Venice. Furthermore, parallels between Shylock and other Jewish characters, i.e. Gernutus, the Mestri Jew, and Barabas, will be drawn. Through a close analysis of Shakespeare's play, Shylock appears to function as an unscrupulous and bloodthirsty usurer attempting to take a Christian's life that is finally taught a lesson and granted Christian salvation. Though driven by his thirst for revenge, Shylock is not depicted merely as a negative stereotypical Jew. During his financial negotiations, Shylock presents himself as an eloquent speaker whose well-aimed and 'carefully-weighed words never miss their target. Moreover, Shylock is pragmatic and argues accordingly. Shylock's eventual transmogrification from an inhuman and obstinate avenger to a suffering human being takes place during the trial scene, leaving the Jew desolate, desperate, and humiliated. Shylock thus embodies 'a dual image of the Jew'. The chapter hence concludes that Shakespeare's Shylock cannot be perceived as a onedimensional villain and usurer; Shylock is a timeless figure allowing for a wide variety of directorial attitudes and interpretations as seen for instance in Václav Lohniský's production of The Merchant of Venice staged in Pilsen in 1954, at the time of the trial with Rudolf Slánský and his supporters.
\end{abstract}

Key Words: The villainous Jew, Gernutus, Christopher Marlowe, Barabas, William Shakespeare, The Merchant of Venice, Shylock, the J.K. Tyl Theatre, anti-Jewish sentiment, verbal usury.

\section{$* * * * *$}

\section{The Figure of the Jew in Literature}

The figure of the Jew is reflected in a stereotypical and negative form already in Medieval English literature. According to a prevalent simplified algorithm, Jews usually represent usurers, villains, evildoers, and even murderers. The aim of this chapter is thus to analyse aspects of the figure of the villainous Jew in English Renaissance literature with focus on Shakespeare's Shylock in the framework of historical and social events, e.g. Roderigo Lopez's case and the economic and 
social situation of the Jewish communities in Tudor London and Renaissance Venice. ${ }^{1}$ Furthermore, similarities and differences between the two Jewish characters, Barabas and Shylock, are pointed out and the sources for The Merchant of Venice are discussed.

\section{Shylockian Analogies and Parallels}

Although the Lopez case may seem marginal from today's point of view, it echoed considerably in Tudor drama (see below). Roderigo Lopez was a Portuguese Marrano (a naturalised Jew of Portuguese origin) residing in London and Queen Elizabeth's personal physician, thus holding a prominent position at Court. In 1594, Lopez was accused of treason and conspiracy to poison the Queen and sentenced to death. ${ }^{2}$ Queen Elizabeth as well as her Chief Advisor William Cecil, Lord Burghley, very likely succumbed to the tense anti-Judaic, or de facto anti-Spanish, atmosphere, considerably incited by Lord Essex who presided over the trial. After the well-publicized court trial, Lopez was eventually hanged, drawn, and quartered at Tyburn on 7 June 1594 as a traitor to the Queen. Lopez's crime was reported shortly afterwards by Francis Bacon in A True Report on the Detestable Treason, Intended by Dr. Roderigo Lopez (1594). The intense antiJudaic atmosphere materialized also on stage, when Marlowe's tragedy The Rich Jew of Malta was flexibly included in the repertoire list and produced. In light of these facts, it can be assumed that Shakespeare might have been familiar with the most notorious Jewish case of the time (and even with Lopez himself), and might have used Lopez as a prototype for his Shylock, yet there is no direct evidence of this. ${ }^{3}$

Though the Lopez affair undoubtedly raised interest in the Jewish issue and might have affected Shakespeare's dramatic invention, it cannot be regarded as a direct parallel to The Merchant of Venice. Themes, motifs, and symbols occurring in the play are primarily associated with the following literary sources: the lost play The Jew, The Ballad of Gernutus, and the first tale of the fourth day from Giovanni Fiorentino's collection Il Pecorone (first printed in Milan in 1558). ${ }^{4}$

The Ballad of Gernutus depicts a dramatic story of the cruel Jewish usurer Gernutus who lends a hundred crowns for twelve months to a Christian merchant, requiring only a pound of the merchant's flesh in return unless the money is paid at the time due. ${ }^{5}$ Both the loan request and the events that followed obviously evoke the themes and motifs of The Merchant of Venice.

The ballad finishes unanimously in the benefit of the merchant, emphasizing his innocence contrary to the cruel and devilish character of the Jew. The ballad and the play show an apparent analogy in the plot construction and at the level of theme and motive. Though the concordance rate between the ballad and the play is easily identifiable, the direction of their mutual influence transfer is only hypothetical due to the fact that the ballad's original date is unknown. 
The Merchant of Venice shares a very close plot line with the first tale of the fourth day from Giovanni Fiorentino's collection Il Pecorone. Central characters, shared by both works, are the story's villain, the Jew, the young man, wooing a beautiful lady (Bassanio/Giannetto), his benefactor, a Christian merchant (friend/godfather), and a beautiful woman (virgin/widow). Even the setting is the same: Venice and Belmont. In Il Pecorone, however, the story revolves primarily around the courtship of the young man Giannetto, in extenso funded by his godfather Ansaldo, the richest among the Christian merchants. The Jewish moneylender, who remains to a certain extent anonymous (being simply referred to as a Jew at Mestri), emerges in the latter part of the tale when Ansaldo begins to furnish Giannetto's third ship for his third voyage and asks the Jew for ten thousand ducats. The Jew's character and his status quo are described through his revengeful discourse condensed into his desire to put to death the greatest of Christian merchants, which clearly reflects all his mercilessness, heartlessness, and bloodthirstiness, considerably emphasized against the background of Ansaldo's immense purity. Regardless of his adamancy, the Jew is finally disposed of both his bond as well as his money.

Despite prevailing parallels between Shakespeare and Fiorentino, it is evident that Shakespeare did not accept the Italian tale passively, but on the contrary, elaborated, modified, and even softened it in many regards. ${ }^{6}$ Fiorentino's Jew thus represents a rather simplified villain and a one-dimensionally flat character whose primary (and in fact only) objective seems to be Ansaldo's death. Unlike Shylock, the Jew's line of thought and family background remain hidden, which may explain a certain flatness and one-sidedness of his interaction with Ansaldo and other persons concerned. The Mestri Jew hence represents the embodiment of wickedness contrary to the Christian merchant, portrayed as an unambiguously positive hero, lacking completely of any bad qualities. In contrast to the Mestri Jew, Shylock appears to be a more plausible protagonist who cannot be unanimously condemned and categorized as a mere evildoer.

Shakespeare was also probably acquainted with Christopher Marlowe's play The Famous Tragedy of the Rich Jew of Malta (written circa before 1591, published in 1633), in which Marlowe portrayed an impressive and bloodthirsty protagonist, Barabas, as a vengeful Jew and villainous usurer.

In Act II, scene iii, Barabas's exhortation to his Turkish slave Ithamore to 'void compassion, love, vain hope, and heartless fear' (II. iii. 171) augments his subsequent self-identification delivered in a Machiavellian discourse, fully uncovering his amoral character. ${ }^{8}$ In his concise self-depiction (II. iii. 175-202), Barabas overtly portrays himself as a thorough malefactor: an engineer during the war between France and Germany, a usurer, a broker, a deceiver, and first and foremost, a killer. ${ }^{9}$ Barabas' image as a well-poisoner evokes an ancient libel about Jews and one of anti-Judaic legends associated with plague outbreaks that hit Western Europe in the years $1348-1350 .{ }^{10}$ Barabas' overall self-portraiture, 
stemming considerably from traditional Jewish and rather anti-Jewish discourse, resembles a macabre mosaic whose appalling tesserae create a picture of the entire villain. Barabas thus represents a quintessence of evil and, as Stephen J. Lynch observes, the worst suspicions about Jews that had evolved over sixteen centuries. ${ }^{11}$

Notwithstanding certain differences, Barabas and Shylock embody many parallel features: they are story-tale villains occupying themselves with usury, they both hate Christians and both have beautiful yet rebellious daughters (Abigail/Jessica). Even the figure of the servant becomes, in a sense, an attribute of both Jewish moneylenders. Barabas' Turkish slave Ithamore and Shylock's virtually improbable (and de facto impossible) Christian servant Launcelot Gobbo represent comic counterparts of their Jewish masters and draw a parallel with Vice, accompanying the Devil in medieval English morality plays.

\section{Jewishness as the Distinctive Trait of the Jewish Villain}

Jewishness was generally associated with usury and hence a simplified parallel between a Jew and a usurer was more than frequently drawn. Usury had also been the official reason for expelling Jews from England towards the end of the thirteenth century. ${ }^{12}$ In the sixteenth century, usury was considered to be illegal until the statutes of 1571 allowed individuals to obtain 10 percent interest on loans. Usury was thus a relatively common commercial activity in Elizabethan England, practised by wealthy merchants and financiers, Protestants and Catholics, yet not Jews. ${ }^{13}$ Regardless of the real situation, the Tudor public opinion adhered to the image of bloodthirsty Jewish usurers, substantially incited and nourished by literary works. Yet, in the Italian city of Venice, where Shakespeare's play takes place, the Jewish ethnic minority dwelled under entirely different conditions than in the English city. Besides, Venetian Jews enjoyed the exclusive status of moneylenders. ${ }^{14}$

Drawing on historical facts, there emerge certain historical inaccuracies in The Merchant of Venice, which might have purposely served Shakespeare as licentia poetica. In light of particular privileges attributed to Venetian Jews, Shylock's position as a rich usurer appears quite realistic. He might have also possibly acquired property, gold, and jewels through usury as Jessica remarks in her utterances. It is nevertheless improbable that a Christian would invite a Jew to his dwelling-place to validate a contract and it is even unthinkable that the Jew would accept it as it happens in Act II, scene v, when Shylock announces the invitation to Jessica. ${ }^{15}$ Needless to say, the invitation of Shylock to dine with Bassanio and Antonio is not motivated by Christian love: Bassanio simply wants to confirm the loan. As viewed through the prism of money lending, Shylock's reaction to Bassanio's request for the loan (I. iii. 1-10) epitomizes a specific phenomenon of the play - verbal usury. ${ }^{16}$ 
Shylock's subsequent utterance (I. iii. 103-125), which represents the first climax of Shylock's discourse, resonates with his inner feelings that anticipate a forthcoming conflict. ${ }^{17}$ The Shylock/Antonio interrelationship is marked by prevailing and basically understandable animosity. Shylock hates the merchant for his Christianity and his unselfish business activities, and Antonio, in return, calls the Jew an infidel, cutthroat and dog. Therefore, unlike his entirely malicious fellow-tribesmen, Gernutus, the Mestri Jew, and Barabas, Shylock has a concrete reason for his hatred, ignited by his antagonist's verbal and physical attacks at Rialto. Antonio's invectives, non-typically re-uttered by Shylock himself, demonstrate an overt anti-Jewish sentiment. Despite their mutual animosity, Shylock, driven by his desire for revenge, consents to lend the acquired sum of money, demanding in jest 'an equal pound of Antonio's fair flesh' if the money is not paid due (I. iii. 145-146). ${ }^{18}$ A pound of flesh from a Christian's body evidently symbolises a variety of ritual murder, representing one of the popular blood libels against Jews. Though the bond is taken, just like in the case of Gernutus and the Mestri Jew, in jest, it clearly anticipates an implicit threat to Antonio, materialized in the course of events.

Although Shylock first and foremost epitomizes a stereotypical, unscrupulous and bloodthirsty villain attempting to take a Christian's life, he cannot be perceived and judged ex parte only in the context of his devilish villainy. Despite being stripped of his humanity for the most of the play, Shylock is a human being, albeit his humanity comes concurrently with his humiliation and undoing. The trial scene leaves Shylock defeated, lonely, and humiliated.

\section{Shylock in the Czech Republic}

Shakespeare's Shylock cannot be understood merely as a schematic villain and moneylender; Shylock is a timeless figure allowing for a wide variety of directorial attitudes and interpretations as seen for instance in Václav Lohniský's production of the play staged in Pilsen in 1954, two years after the trials against Rudolf Slánský and his supporters, when the Jewish issue was still particularly topical. ${ }^{19}$ In this respect, there appears to be a certain parallel between the assumed Jewish conspiracy within the Communist Party and Shylock, who was hence portrayed as a negative figure, representing betrayal and deserving a severe punishment. Conversely, considering the choice of Saudek's translation, it is not out of question that some sympathy with and feelings for Shylock might have been indicated during the performance. ${ }^{20}$ It is supposable that the performance thus served not only to entertain and educate audiences, but also to voice objections to the authoritarian regime. Due to the timeless character and conception of the play, Shakespeare's Venice served not only to portray Elizabethan London, but also the socio-political climate in 1950s Czechoslovakia. 


\section{Notes}

1 This study was supported by The Czech Science Foundation project GAČR 405/09/P035.

2 D.S. Katz, The Jews in the History of England, 1485-1850, Oxford University Press, Oxford, 2002, pp. 49-96.

${ }^{3}$ Being a member of the College of Physicians, Roderigo Lopez was the medical attendant of many notables of the time, including the Earl of Leicester, Shakespeare's early patron. J. Palmer, Comic Characters of Shakespeare, Spencer Press, 2008, p. 53.

4 As the text of the play The Jew has not been preserved, any assumptions concerning correlations with and differences from Shakespeare's play remain merely hypothetical.

5 F.J. Child (ed), English and Scottish Ballads, Vol. VIII, Little, Brown and Company, Boston, 1860, pp. 45-57.

${ }^{6}$ V.K. Janick, The Merchant of Venice: A Guide to the Play, Greenwood Press, Westport, Conn., 2003, pp. 37-46.

7 Serving as a typical example of Machiavellian policy and amoral reasoning, Barabas stops at nothing to carry out his vendetta on both the Christians and the Turks.

${ }^{8}$ C. Marlowe, D. Bevington \& E. Rasmussen (eds), Doctor Faustus and Other Plays, Oxford University Press, Oxford, 2008, p. 278.

${ }^{9}$ Ibid., pp. 278-279.

${ }^{10}$ The time of hopelessness and despair created a more recent version of an immemorial myth, according to which Jews poisoned wells and brooks in order to exterminate Christians.

${ }^{11}$ C. Marlowe \& S.J. Lynch (eds), The Jew of Malta: With Related Texts, Hackett Pub. Co., Indianapolis, 2009, p. xvi.

12 Jews were officially expelled from England by Edward I in 1290 and were not allowed to come back until Oliver Cromwell's decision in 1655.

${ }^{13}$ V.K. Janick, The Merchant of Venice: A Guide to the Play, Greenwood Press, Westport, CT, 2003, pp. 30-33.

${ }^{14}$ P. Johnson, Dějiny židovského národa [A History of the Jews], Rozmluvy, Praha, 1995, pp. 232-233.

${ }^{15}$ It is nevertheless important to mention that Shylock declines the first invitation.

${ }^{16}$ W. Shakespeare, The Merchant of Venice, trans. M. Hilský, Atlantis, Brno, 1998, pp. 47-51 \& pp. 134-137.

${ }^{17}$ Ibid., pp. 142-145.

${ }^{18}$ Ibid., pp. 142-147.

${ }^{19}$ Rudolf Slánský (1901-1952) was a leader of the Jewish faction within the Czech Communist Party. He was arrested in 1951, accused of Titoism, Trotskyism, 
Zionism, and collaboration with the West. In November 1952 Slánský was found guilty and sentenced to death.

20 Erik Adolf Saudek (1904-1963), the outstanding Czech Shakespearean translator, was a Jew.

\section{Bibliography}

Cohen, D., 'Critical Approaches'. The Merchant of Venice: A Guide to the Play. Janick, V.K. (ed), Greenwood Press, Westport, CT, 2003.

Cheyette, B., Constructions of 'the Jew' in English Literature and Society: Racial Representations, 1875-1945. Cambridge University Press, Cambridge, 1996.

Child, J. (ed), English and Scottish Ballads. Vol. VIII. Little, Brown and Company, Boston, 1860.

Hilský, M., 'Libra masa' [A Pound of Flesh]. Kupec benátský [The Merchant of Venice]. trans. Hilský, M., Atlantis, Brno, 1998, p. 33.

James, B. \& Rubinstein, W., The Truth Will Out: Unmasking the Real Shakespeare. Harper Perennial, New York, 2006.

Janick, V.K., The Merchant of Venice: A Guide to the Play. Greenwood Press, Westport, CT, 2003.

Johnson, P., Dějiny židovského národa [A History of the Jews]. Rozmluvy, Praha, 1995.

Katz, D.S., The Jews in the History of England, 1485-1850. Oxford University Press, Oxford, 2002.

Marcus, J.R. \& Saperstein, M., The Jew in the Medieval World: A Source Book, 315-1791. Hebrew Union College Press, Cincinnati, 1999.

Marlowe, C, Bevington, D. \& Rasmussen, E. (eds), Doctor Faustus and Other Plays. Oxford University Press, Oxford, 2008.

Marlowe, C. \& Lynch, S.J. (eds), The Jew of Malta: With Related Texts. Hackett Pub. Co., Indianapolis, 2009. 
Muir, K., The Sources of Shakespeare's Plays. Routledge, London, New York, 2005.

Palmer, J., Comic Characters of Shakespeare. Spencer Books, 2008.

Pavlát, L., Židé - dějiny a kultura [Jews - History and Culture]. Židovské muzeum v Praze, Praha, 2005.

Potok, C., Putování. Dějiny Židi̊ [Wanderings - A History of the Jews]. trans. Adamová, E., Geissler, E. \& Kováŕík, Š., Argo, Praha, 2002.

Shakespeare, W., Kupec benátský [The Merchant of Venice]. trans. Hilský, M., Atlantis, Brno, 1998.

-, The Complete Works. Wells, S. (ed), $2^{\text {nd }}$ ed., Oxford University Press, Oxford, 2005.

Stříbrný, Z., Shakespeare and Eastern Europe. Oxford University Press, Oxford, 2003.

Škanderová, I., Vrcholná období recepce her Williama Shakespeara na plzeňských scénách [Greatest Periods of Reception of Shakespeare Productions on Pilsen Stages]. Aleš Čeněk, Plzeň, 2005.

Ivona Misterova is a lecturer at the Department of English Language and Literature at the University of West Bohemia in Pilsen. She received her Ph.D. in English and American Literature from Charles University in Prague. She conducts research in the area of theatrical interpretations of English and American plays performed on Pilsen theatre stages in the context of $20^{\text {th }}$-century events. She is the author of the book entitled Greatest Periods of Reception of Shakespeare Productions on Pilsen Stages (2005). 


\title{
The Strategies of Narrative Representation of Villains in English Renaissance Rogue Literature
}

\author{
Kateryna Vasylyna
}

\begin{abstract}
Literature about villains and different kinds of villainy evolved and quickly won its popularity among the readership of the Renaissance England. Paying attention to different kinds of underworld activities, Tudor writers singled out the outlaws engaged in property crimes as these were considered to be the most dangerous ones in the epoch of primary accumulation. The authors of the early books of vagabonds and sturdy beggars aimed at warning common people against this social evil. The functional scope of rogue literature was enlarged due to Robert Greene who created conny-catching pamphlet as a peculiar literary genre. Having University education and the established reputation of 'Homer of women' in the realm of romance he applied his artistic skills to picturing villains. The main bulk of information was taken from the books by his forerunners (R. Copland, G. Walker, T. Harman) and from his personal life experience. Using different narrative strategies to make the criminal world look more picturesque and vibrant the writer altered his manner of presentation from business-like and dry type to a refined literary one. Greene widened the scope of literary tools by blending techniques typical of treatise and romance so the readers could not only follow the thirdperson narration with moralistic bias but also enjoy bright dialogues between criminals, some monologues of villains, their boastful autobiographical stories and a lot of amusing inserted texts. Manner of presentation was also varied from a scholarly to a highly metaphoric kind, which made the pamphlets appealing to different recipients. Gradually Greene made his image of villains more and more attractive, which can be explained by the apology of creativeness that was a key element of the Renaissance paradigm of values. Greene's aesthetic experiment proved to be highly productive and popular among the following generations of fiction-writers (from T. Nashe and R. Head to J. Bunyan and D. Defoe).
\end{abstract}

Key Words: Renaissance, creativeness, property crime, rogue literature, books of vagabonds, conny-catching, pamphlet, genre, cony.

$* * * * *$

English rogue literature evolved in the early years of the $16^{\text {th }} \mathrm{C}$. as a cultural reaction to the new tendencies in economic and social life. English society of the period faced wide spread of a new class of mobile, rootless, poor and masterless people who constituted real danger to it. ${ }^{1}$ Assertion that, "there is no country in the world where there are so many thieves and robbers as in England; insomuch that few venture to go alone in the country, excepting in the middle of the day, and 
fewer still in the towns at night, and least of all in London' ${ }^{2}$ had become commonplace.

The government tried to control the outsiders by registering them, giving licenses for begging, putting into prison or sending to the gallows. Though there appeared numerous parliamentary acts aimed at improvement of the situation, there were a lot of tricks to avoid punishment (by the right of clergy, by bringing fake witnesses etc.) and up to $80 \%$ of criminals evaded trial. ${ }^{3}$

The English were under constant danger of coming into contact with the villains and so they had to be on the alert. New phenomenon though dangerous was at the same time attractive for common people thirsty for scandalous and sensational reading. Evolution of rogue literature was as rapid as the spread of villainous stratum of society. Within a century books of vagabonds and sturdy beggars developed from dry, business-like, precise reports and protocols of rogues' types to the refined stories of roguery.

Wide spread of such literature was predetermined by the Renaissance outlook which considered every side of life worthy of depiction. Renaissance people were trying to subvert all the taboos to create a new kind of morale and thus all kinds of unworthy deeds were treated as natural manifestations of independence and activity of a personality. ${ }^{4}$ A prominent Russian philosopher A. Losev stresses that these manifestations marked the development of 'spontaneous individualism of the epoch'. ${ }^{5}$ Attention to the shadow sides of existence proved that the Renaissance personality strived to study all aspects of life to define their functions in the Universe.

As there were no established modes of depicting criminal world the authors of rogue literature tended to use different 'ready-made' elements of non-fiction to serve their purpose. Hence the scope of genre types and narrative techniques of the writings was wide and differed in accordance with dominant intention, aesthetic preferences and artistic experience of the author.

R. Copland in his poem 'The Highway to the Spital-House' (1535-36) presents moralistic description of Elizabethan underworld. In prologue he ponders over the moral aspects of poverty and stresses that it is not a $\sin ^{6}$

In dramatic dialogue Copland focuses on the idle poor. It is dialogue only in form as there are no contradictory points of view but two voices in tune each of them having a peculiar function and the similar aim. Here the images of the narrator and of the beggars' world are split. The speaker (Copland) shows a great interest in the subject and seeks for support of his point of view from the interlocutor by putting reasonable questions, giving examples from life.

The porter as a connoisseur of the under classed answers the questions, classifies different types of people turning to the spital-house and gives laconic characteristics to them. Making the porter the main expert in underworld the author keeps distance from the information and avoids being associated with the representatives of shadow side of urban life. Moreover the poet doesn't make his 
characters round as like in moralistic play here they are only mouthpieces for the writer's clearly identified ideas.

To make his narration plausible the author uses description of a certain chronotope. The main means of depicting spital-house dwellers is their direct characteristics given by the porter. Copland uses the techniques typical of treatise based on precision of descriptions as well as on pretensions for objectivity. Due to the vast scope of the presented types of villains this book seems to comply with the tradition of satirical writings ${ }^{7}$ and the so-called 'mirrors' as well as the 'anatomies', which showed different vices of society in detail and appealed for their amendment.

The main vices of spital-house visitors are their coveting and idleness that are sure to bring them to misery. Copland includes elements of homily into his book to emphasize the moral side of poverty. He doesn't severely denounce the beggars but acts as a preacher turning to some Biblical concepts and ecstatic appeals to God to correct the evildoers. ${ }^{8}$

According to Copland the chief characteristics of the beggars are their multiplicity and unity, ${ }^{9}$ mobility ${ }^{10}$ and unscrupulousness. ${ }^{11}$ Still he lays stress not on the losses, which the villains cause, to other people but on the damages they bring to themselves. Differentiating between invalid beggars and mighty ones, giving few direct accusations to the latter, the author lays basis for ambivalent perception of the concept of villainy. His tolerant attitude to all the poor as well as lack of contempt to them is shown in the last words of the poem as he illustrates instability of societal statuses. ${ }^{12}$ Copland's book is a kind of link between earlier satirical approaches to depicting social vices to more objective perception of the phenomenon.

Later tradition showed peculiar interest to the separate class of the outlaws, which were active in their desire to get profit by depriving common people of their property. This can be easily understood in the context of Renaissance apology of activity and creativeness as well as against the background of social and economic mobility of the time. It is stated that 'images of the early modern rogue created a cultural trope for mobility, change, and social adaptation. ${ }^{13}$

'A Manifest Detection of the most Vile and Detestable use of Dice-Play' (1552) ascribed to Gilbert Walker is centered on a peculiar class of villains. The author makes use of 'mirror' genre rather popular in the Renaissance to reveal the vice minutely. Following in the footsteps of his predecessor Walker gives excuses for writing about such 'naughty practices' in the foreword and clarifies that he disapproves only of the dishonest dice-players.

The names of dice are given as a separate textual fragment and it is the first time that the list of peculiar words of the underworld cant has been included into the text. This tradition of introducing jargon into fiction in forms of tables, lists, lexicons etc. will be very popular in the works to follow. 
Walker's piece is written in a form of a dialogue between a novice and an expert. The author alienates himself from the presented material by introducing the two characters. Giving interlocutors no names but identifying them as R. and M. he creates the atmosphere of secretiveness and plausibility of the presented material. One can feel the influence of morality plays where characters were just emblematic figures and stood for certain concepts (R. - inexperience and vulnerability, M. experience and awareness).

The text includes descriptions of the cheaters and their practices and exemplary stories to illustrate the given information. Walker nourishes his book with techniques typical of literary fiction mingling treatise-like descriptive passages with more lively and catching stories full of dialogues and actions.

$R$. tells a vivid tale and represents villainy as seen by an inexperienced victim. In this text one can see the outside appearance of the villainy: how rogues come in contact with the victims, involve them into play and get money out of the losers. In this part the author gives no direct characteristics to the villains but presents them through behaviour (which seems rather decent) and their speech (exquisite, flattering and devoid of any obscure words).

Seeing the other side of the phenomenon M. starts revealing his vision of the situation by giving direct description of the crew. This interlocutor's speech is formatted as a treatise-like narration accompanied with vivid examples. Walker pays attention to good organization of the villains as he uses the word 'law' to nominate their practices. ${ }^{14} \mathrm{He}$ asserts that there is a certain language of villains and subtle methods to cheat people. Walker draws parallel between the activity of the dicers and the work of the craftsmen arguing that as carpenters have their terms so do the villains, ${ }^{15}$ and that cheaters' dexterity is achieved through practice. ${ }^{16}$ These marked similarities along with few accusations against villains add to creating positive image of well-organized, skilled and successive rogues.

Books by J. Awdeley, 'The Fraternitye of Vagabondes' and T. Harman, 'A Caveat or Warning for Common Cursitors', are the catalogues of different types of rogues which constituted the bulk of information extensively borrowed by the followers. Awdeley compiles a manual for those who want to know the deceitful practices. At the same time he hints at truthfulness of the presented material stating in the introductory part that all the testimony was received from a vagabond at trial. The main mode of presenting villainy in the text is scholarly and dry. Even when the author develops on some practices he still uses generalized descriptions. To make the account more vivid and feasible Awdeley includes many special words of rogue vocabulary. The community of villains here is also viewed as united and multiple, ${ }^{17}$ well-organized and strictly observing the hierarchy, ${ }^{18}$ varied in types ${ }^{19}$ and successful. ${ }^{20}$ The author doesn't use evaluative epithets to castigate the villains.

Using the structure suggested by Awdeley, T. Harman nourishes it with interesting and bright inset stories. It is the plot part within the framework of 
plotless narration that made the piece more attractive to the readers. The text presents a mixture of prose and poetry, including a list of names of known villains, a lexicon of cant and an original dialogue between rogues both in cant and in translation into normal language. In Harman's book the image of rogue community is becoming more familiar and less frightening.

At the end of the $16^{\text {th }} \mathrm{C}$. due to creative activity of a notorious writer of the Renaissance Robert Greene rogue literature was enriched by such new literary production as the conny-catching pamphlet.

This sub-genre of Elizabethan pamphletistics presents an original vision of criminal community, reflects the shift in the reception of the image of villain and to some extent stipulated that shift.

It is believed that Robert Greene coined the term 'conny-catching' to name a special type of knavish tricks and pictured conny-catchers as inventive people who are very fast at finding the victim and stripping this lusty and jealous person of his possessions. The pamphlets were of a controversial character as they not only created a romantic and rather positive aura around different kinds of cheaters but also produced a rather skeptical attitude to the victims of the villains, which were called 'connies'. Let's remind that a cony (rabit) 'signified 'willing prey' or 'naive quarry'. ${ }^{21}$

In his first conny-catching pamphlet ${ }^{22}$ Greene describes tricks used by London rogues in a form of a treatise. The introductory part in which Greene justifies the idea of presenting the material to the readership in order to warn the people and to call for amendment is ornamented in euphuistic manner - long sentences are full of comparisons, apostrophes, allusions to the antiquity and so on. The overall image of villains explicitly created by the author is negative as they are directly nominated as 'hazardous', 'dangerous', 'cooseners', 'vipers', 'worms' and 'caterpillars' etc.

In the second part of the pamphlet Greene gives detailed and precise description of the 'art of conny-catching' and the 'art of cross-biting'. Though the writer goes on giving explicit negative characteristics to the villains still the fact that he calls their tricks 'art' hints at the admiration of subtlety and skillfulness of their deeds.

The pamphlet represents a table of words used by the villains and 'A pleasant discovery of the coosenage of colliars' where Greene appeals not only to moralistic meditations but to the jest-book technique to amuse the readers.

In the second pamphlet ${ }^{23}$ treatise-like precise description of certain types of criminal arts is accompanied by exemplary tales. The tales are called 'merry' and they are arranged as jest-book stories that fulfill the function of entertaining the readers. Though in some of the jests the villains are punished by common people, still positive perception of the image of villainy is dominant.

In the third pamphlet ${ }^{24}$ Greene devotes the major part of textual space to different tales about villains and their adventures. The writer goes on nominating 
the cheaters as 'sturdy', 'loose', 'lewd', 'cunning', 'counterfeit', 'base-natured' and even 'hellish crew'. But by giving indirect characteristics through deeds he creates an impression that villains are worthy of praise and admiration as they achieve their aim.

At the same time it becomes clearer that the common gentlemen (victims) are not very clever and noble. Though the author calls conies 'honest citizens' still he hints that conny-catchers prey on lustful, greedy and foolish individuals who readily come into contact with them. Due to the skilful use of narrative techniques the victim turns out to be the object of criticism. Thus one can witness inversion of readers' perception of the general paradigm of vices and dignities: through their stupidity and naivety conies seem to be a rather repulsive image for the Renaissance people.

In the last two pamphlets Greene shows shift towards the techniques of romance which being blended with jest tradition give birth to a romance of roguery. In 'Disputation between a Hee-conny-catcher and a Shee-conny-catcher' Greene characterises villains through their speech as well as through their deeds and thus the presence of the image of the writer is reduced to the foreword and end-word space only. It is natural that as the speakers are criminals they cannot blame themselves or their accomplices and thus boastful tone of their remarks as well as successful character of their efforts add positive connotation to the image of villains. The main question disputed in the dialogue is "whether a theefe or a Whoore, is most hurtful in Cousonage, to the Common-wealth ${ }^{25}$ so Greene who had already won the reputation of the 'Homer of women' ${ }^{26}$ introduces gender differentiation into rogue fiction. ${ }^{27}$

The pamphlet contains the confession of a courtesan who turned into a respectable woman. Here the author uses not only elements of romance, jest-books but also autobiographical, confessional writings and repentance pieces in the style of prodigal son parables. The writer tries to discover social and personal causes for people leading precarious life and meanwhile indirectly creates attractive image of idle existence.

Having had success with his aesthetic experiments Greene goes on with that and in 'The Blacke Bookes Messenger' he reproduces the life of a notorious villain Ned Browne through 'I-narration'. Here one can observe tendency towards individualization of the image of villain. Greene is no longer interested in depicting non-individualized mob of cheaters and focuses on an individual fate of a criminal protagonist.

In this pamphlet Greene uses a required preamble to announce his intentions, a traditional table of slang words, and leaves the majority of narrative space to Ned Brown's monologue. Applying previously tested narrative techniques the author adds some elements of autobiography the popularity of which was stipulated by Renaissance apology of individualism. ${ }^{28}$ Greene lets Ned characterize himself through speech and evaluate his colleagues and victims. Boastful mode of Ned's 
narration shows his character in full and affirms his satisfaction with the way he lived. Ned Brown challenges the society, ${ }^{29}$ treats his life as an amusing one and calls on the readers to enjoy his story.

Thus being sensitive to the demands of the reading public defined by the Renaissance apology of creativeness Greene made his image of villains more attractive. His aesthetic experiment proved to be popular among the following generations of fiction-writers.

\section{Notes}

${ }^{1}$ Arthur F. Kinney points out that the phenomenon was typical of Tudor reality and to support his idea he gives interesting evidences of the contemporaries. More detailed information is contained in Rogues, Vagabonds and Sturdy Beggars: A New Gallery of Tudor and Early Stuart Rogue Literature, A.F. Kinney (ed), University of Massachusetts Press, 1990, p. 16.

2 A. Judges, 'Introduction', The Elizabethan Underworld, A. Judges (ed), George Routledge \& Sons Ltd., London, 1930, p. 15.

${ }^{3}$ J.S. Cockburn, 'The Nature and Incidence of Crime in England 1559 - 1625: A Preliminary Survey', Crime in England: 1550-1800, J.S. Cockburn (ed), Princeton Univ. Press, Princeton, New Jersey, 1977, p. 50.

${ }^{4}$ More detailed information about different sides of Renaissance personality is given in the article by Ukrainian expert in the Renaissance prof. Nataliya Torkut (Н.M. Торкут, 'Провідні ідейно-смислові концепти італійського гуманізму (спроба культурологічної реконструкції), у Біблія $i$ культура: Зб.наук.статей, Вип.7, 2005, сс. 284-296).

${ }^{5}$ А. Ф Лосев, Эстетика Возрождения, Мысль, Москва, 1978. с. 120.

${ }^{6}$ Copland uses apostrophe to make his idea explicit: 'I pray all you, which have enough with grace,/ For the love of God to do your charity,/ And from the poor never turn your face,/ For Christ saith, Whatever that he be/ That to the least of Mine doth in the name of Me,/ Unto Myself I do accept the deed, And for reward my realm they shall possede'. R. Copland, 'The Highway to the Spital-House', The Elizabethan Underworld, A. Judges (ed), George Routledge \& Sons Ltd., London, 1930, p. 3.

${ }^{7}$ Here the influence of the satirical tradition as presented by G. Chaucer's in his works is rather obvious. Still this question deserves to be the theme of a separate research.

${ }^{8}$ For example: 'be satisfied with what you possess, if you misuse what God has sent you, you will be brought to hell together with Dives and certainly 'more easily a great camel/ May pass and go through a needle's eye/ Than a rich man in Heaven for to be' or 'I pray God them amend,/ Or as they be to bring them to an end'. Copland, op. cit., pp. $2 \& 12$.

${ }^{9}$ He calls their groups 'sects', gives some examples of their special language. 
${ }^{10}$ This idea is repeatedly underlined through the usage of the word 'loitering'.

${ }^{11}$ Copland describes 'some counterfeit lepry, and other some / Put soap in their mouth to make it scum,/ And fall down as Saint Cornelys' evil'. Copland, op. cit., p. 7.

12 'To eschew vice I thee undertook,/ Disdaining no matter of creature. I were to blame if I them forsook; none of this world of wealth can be sure'. Ibid., p. 25.

${ }^{13}$ C. Dione \& S. Menz, 'Introduction: Rogue and Early Modern English Culture', Rogues and Early Modern English Culture, C. Dione \& S. Menz (eds), The University of Michigan Press, 2004, p. 1.

14 The author gives explanations to the names of the laws: sacking law whoredom, high law - robbery, figging law - pick purse craft. G. Walker, 'A Manifest Detection of the Most Vile and Detestable use of Dice-Play and Other Practices Like the Same', The Elizabethan Underworld, A. Judges (ed), George Routledge \& Sons Ltd., London, 1930, pp. 35-36.

15 'But always ye must consider that a carpenter hath many terms, familiar enough to his 'prentices, that other folk understand not at all; and so have the cheaters, not without great need, for a falsehood, once detected, can never compass the desired effect'. Ibid., p. 36.

${ }^{16} \mathrm{M}$ pathetically puts a rhetorical question 'But what is that labour overcometh not?', Ibid., p. 39.

17 The author uses words like 'fraternity' and 'brotherhood' to characterise the villains.

${ }^{18}$ To illustrate this it is necessary to pay attention to one of the definitions: 'An Uprightman...is of so much authority, that meeting with any of his profession, he may cal them to accompt, \& command a share or snap unto himselfe... And if he doo them wrong, they haue no remedy agaynst hym...'. J. Awdeley, 'The Fraternitye of Vagabondes', Awdeley's Fraternitye of Vagabondes, Harman's Caueat, Haben's Sermon, etc, № 9, Early English Text Society, Berlin - New York - Philadelphia, 1889, p. 4.

19 The writer mentions different types of villains: ruffling and beggarly, men and women, boys and girls etc.

${ }^{20}$ Even the fact that a vagabond is giving testimony to the jury doesn't necessarily presuppose the idea of punishment.

${ }^{21}$ Dione \& Menz, 'Introduction:', op. cit., p. 6.

${ }^{22}$ The title of the first conny-cayching pamphlet is 'A Notable Discovery of Coosnage, Now daily practiced by sundry lewd persons called Connie-catchers, and Crosse-biters' (1591).

${ }^{23}$ This pamphlet is entitled 'The Second and Last Part of Conny-catching with New Additions containing many merry tales of all lawes worth the reading, because they are worthy to be remembered'. 
${ }^{24}$ The full title of this piece is 'The Third and Last Part of Conny-Catching with the New-Devised Knavish Art of Fool-Taking, the like cozenages and villainies never before discovered'.

${ }^{25}$ R. Greene, 'A Disputation Between a He-Conny-Catcher And A She-ConnyCatcher', The Elizabethan Underworld, A. Judges (ed), George Routledge \& Sons Ltd., London, 1930, p. 206.

${ }^{26}$ P. Salzman, English Prose Fiction, 1558-1700: A Critical History, Clarendon Press, Oxford, 1985, p. 6.

${ }^{27}$ Earlier, the focus of such writings was men and harlots were only their assistants. From now-on she-criminals became rather popular in English literature and there developed a female branch of literature of roguery.

${ }^{28}$ It is necessary to stress that due to the Renaissance apology of individualism autobiography which presented a self-centered experience of a free individual became widely popular among the readership. Following the pattern of ancient biographies English writers created a literary variant of the type. More detailed information about English Renaissance memoirs writing can be found in the book by prof. Nataliya Torkut (H.M. Торкут, Проблеми генези $і$ структурування жанрової системи англійської прози пізнього Ренесансу (малі епічні форми ma 'література факту'), Запоріжжя, 2000, с. 341-367).

${ }^{29}$ Ned says: 'If you thinke (gentlemen) to heare a repentant man speake, or to tel a large of his penitent sorrowes, ye are deceiued; for as I haue euer liued lewdly, so I meane to end my life as resolutely, and not by a cowardly confession to attempt the hope of pardon'. R. Greene, 'The Blacke Bookes Messenger', The Bodley Head Quartos, G.B. Harrison (ed), John Lane The Bodley Head Ltd., Vigo Street, London, 1924, p. 5.

\section{Bibliography}

Awdeley, J., 'The Fraternitye of Vagabondes'. Awdeley's Fraternitye of Vagabondes, Harman's Caueat, Haben’s Sermon, Etc.. № 9, Early English Text Society, Berlin - New York - Philadelphia, 1889.

Cockburn, J.S., 'The Nature and Incidence of Crime in England, 1559-1625: A Preliminary Survey'. Crime in England: 1550-1800. Cockburn, J.S. (ed), Princeton Univ. Press, Princeton, New Jersey, 1977.

Copland, R., 'The Highway to the Spital-House'. The Elizabethan Underworld. Judges, A. (ed), George Routledge \& Sons Ltd., London, 1930. 
Dione, C. \& Menz, S., 'Introduction: Rogue and Early Modern English Culture'. Rogues and Early Modern English Culture. Dione, C. \& Menz, S. (eds), The University of Michigan Press, 2004.

Greene, R., 'A Disputation between a He-Cony-Catcher and a She-Cony-Catcher'. The Elizabethan Underworld. Judges, A. (ed), George Routledge \& Sons Ltd., London, 1930.

—, 'The Blacke Bookes Messenger'. The Bodley Head Quartos. Harrison, G.B. (ed), John Lane The Bodley Head Ltd., Vigo Street, London, 1924.

Judges, A., 'Introduction'. The Elizabethan Underworld. Judges, A. (ed), George Routledge \& Sons Ltd., London, 1930.

Salzman, P., English Prose Fiction, 1558-1700: A Critical History. Clarendon Press, Oxford, 1985.

Walker, G., 'A Manifest Detection of the Most Vile and Detestable use of DicePlay, and Other Practices Like the Same'. The Elizabethan Underworld. Judges, A. (ed), George Routledge \& Sons Ltd., London, 1930.

Лосев, А.Ф., Эстетика Возрождения. Мысль, Москва, 1978.

Торкут, Н.М., 'Провідні ідейно-смислові концепти італійського гуманізму (спроба культурологічної реконструкції)'. Біблія $і$ культура: Зб.наук.статей, Вип.7, 2005, сс.284-296.

Торкут, Н.М., Проблеми генези і структурування жанрової системи англійської прози пізнього Ренесансу (малі епічні форми та 'література факту'). Запоріжжя, 2000.

Kateryna Vasylyna, is an associate professor at Zaporizhzhia National University (Ukraine) and teaches English and West-European literature to the students of Foreign Philology Department. Her current research is focused on genre and style peculiarities of English rogue literature of XVI-XVIII C. 


\title{
Damnation of a Hero or Villain: Christopher Marlowe's The Tragical History of the Life and Death of Doctor Faustus
}

\author{
Seyda Inceoglu
}

\begin{abstract}
In this chapter, the focus will be on the Faustus myth in which Faustus is an overreacher, in pursuit of self knowledge, which he will achieve by going beyond the boundaries of traditional knowledge as propagated by the Orthodox institutions in the given culture. ${ }^{1}$ The Faustus myth, before being identified as a myth, was the folktale of a man named Faustus who lived in Germany. After his story became popular, he reappeared, even in contemporary culture, in different art forms such as literature both highbrow and popular, including comics, the ballet and the opera. The real historical Faustus came onto the scene as a scholar and persistently reappeared in literature assuming different identities, which however, shared basically the same qualities. In this study, the text of Christopher Marlowe's The Tragicall Hiftory of the Life and Death of Doctor Favstvs which followed the original story of P.F. Gent's translation of The Damnable Life and Deserved Death of Dr. Faustus from Johann Spies' publication of the German Faustus Book is going to be analysed and interpreted. In spite of the different ages, cultures, histories, philosophies, what is common in all is that Faustian man and the basis of the Faustus myth has never changed and the underlying qualities remain the same throughout history. The Faustus myth starting with a historical person mirrors the Renaissance ambition of transcending the restrictions and limits drawn by God, and then it progresses towards the Enlightenment Period in which magic is overshadowed by money and materialism. Then gradual change gives birth to ambiguous, blurred, confusing values in the twentieth century. How each era, particularly the Renaissance Age, creates its own Faustus whether as a hero or a villain in a context of societal, political and historical in spite of the fact that the main concerns almost remain same is going to be scrutinized in this chapter.
\end{abstract}

Key Words: The Faustus Myth, the Renaissance Age, the Renaissance ambition, The Tragical History of the Life and Death of Doctor Faustus.

$* * * * *$

The myth of the individualistic, proud overreacher Faustus has been modified and retold throughout centuries. Faustus, in search of the discovery of the true self, his true power, transcending the physical self and material world, building a bridge between this world and the other world, craving the sublime power of God, has been one of the mythical figures associated with complex human problems. On the one hand, Faustus, being a scholar, and on the other hand being a magician with forbidden powers, appeals to human beings since most individuals suffer from 
intellectual contradictions resembling those undergone by Faustus. This contradiction brings the controversial idea whether Faustus is going to be considered as a hero or a villain. Faustus is neither a sacred character nor god or demi-god; he experiences the kind of disturbance, ambition, chaos that almost all human beings experience. This chaotic situation originates from his desire to assume power beyond that given by God, in other words to reach the secrets of this and the other world.

Christopher Marlowe, who made the story of Faustus widely known, followed the original story of P.F. Gent's translation of The Damnable Life and Deserved Death of Dr. Faustus from Johann Spies' publication of the German Faustus Book. Due to the upheavals in the years that were written, The Faustus Book is considered as a moral lesson and a warning to the Christian readers to avoid the devil and trespassing the boundaries set by God. Moreover, Christopher Marlowe followed the same moral as Johann Spies' The German Faustus Book. Without a doubt, Marlowe wrote the play in a time of economic, political uncertainties and depression in both England and in Europe. On the other hand, both the Renaissance and also the Reformation brought new spirit to both cultural and religious issues. $(\mathrm{Re})$ Defining the role and the meaning of the individual in the universe improved the views on the potentials of human beings. Awakening potentials in the individuals, the enlargement of the intellectual mind and cultural territories also resulted in the colonial expansion with the enlargement of geographical territories. Also, there were rising Puritans, which do not accept any mediators between God and human beings, their existence alongside with the political vagueness, and intellectual concern of the anxious scholars create Faustus.

Chaotic England with economic and political uncertainty, the existence of Puritan society which believes that the English Reformation was not successful enough in reforming the doctrines and structure of the church and intellectual's anxiety upon the future of England created Faustus who declared himself as a second god. Man was himself a second god (as Faustus' being second magus who acts as an overreacher), a divine being representative of God in this world, ruler of the earth and king of all God's creations. Renaissance man lived in a world, which had been specially built for him and over which he was lord and master. Fields and mountains, animals and plants, even metals and stones were put on solely for his convenience and use. ${ }^{2}$ Thus, a male's myth centred upon his sovereignty over the universe was inevitable. However, for Faustus, mere possession of the earth was not enough, he also had to learn the secrecies of the other world thus, abandoning legitimate studies, he turns to spiritual forces through magic that he thinks that it will lead him to self-knowledge, secrets of universe and power. In the introductory speech of the chorus, Faustus is identified with Icarus: 
So much he profits in divinity,

That shortly he was graced with doctor's name,

Excelling all, and sweetly can dispute

In th' heavenly matters of theology;

Till swoll'n with cunning of a self-conceit,

His waxen wings did mount above his reach,

And, melting, heavens conspired his overthrow.

For, falling to a devilish exercise,

And glutted now with learning's golden gifts,

He surfeits upon cursed Necromancy;

Nothing so sweet as magic is to him,

Which he prefers before his chiefest bliss.

And this the man that in his study sits. ${ }^{3}$

The Icarus image symbolizes the sin against the rule and commands of divine wisdom and alludes to an already fallen and damned mythical 'hero', Dr. Faustus in the beginning of the play. In Greek mythology, Icarus, neglecting the instructions of his father, Daedalus, flied too close to sun just for the sake of flying high. Consequently, the waxwings melted and Icarus fell into the sea and drowned. The artist, Daedalus, being aware of his potentialities and limits, is saved since he knows his boundaries and acts accordingly. However, his son ignores the limits and flies high above his reach and as a result of this act he is punished according to the myth. The father's neglect and failure to watch out for his son are significant in signalling to God's eye on his own creatures in a world where the earth is no longer central in the universe. The Icarus image signifies the immature artist and also the overreacher. Moreover, the use of Icarus image in the play is also a foreshadowing to the end of the play since the image is closely linked with the downfall. Thus, we could say that the play begins and ends with the same downfall imagery. The play starts with the words of Chorus, which represents a societal narrative evaluating and commenting on the position of Dr. Faustus within society. Chorus, which is a voice that is existent in Greek Tragedy, forms a frame narrative in Dr. Faustus.

The chorus, which determines the boundaries of the text in Dr. Faustus, controls and frames the narrative. The choice of Marlowe's using the chorus in the play is a distortion of Greek Tragedy since he only uses it in the beginning, in the middle and in the end to create a societal resolution, which frames the narrative determining the limits of the text. It creates order within chaos. The chorus in Marlowe's text represents an intellectual group of people that share the same anxiety for the chaotic situation of England. This chaotic condition is uttered by the chorus framing the chaotic and evil text of Dr. Faustus and it determines the limits of the content. It is significant that a chorus should choose Icarus, the disobedient son to admonish the tragic hero of the play. Faustus, representing the tragic hero in 
the play, is closely linked with Icarus' being disobedient son to his father Daedalus. Thus, Faustus could also be seen as a curious rebellious son to God. Besides Icarus' being a representative of a fallen character, he can also be seen as a positive, romantic figure that is ready to risk failure and death just for the sake curiosity to satisfy his adventurous self. Faustus is ready to risk his scholarly life to 'the devilish exercise'. Due to his curiosity, his hunger for reaching beyond the limits set by God, he is attracted to the devilish exercise: necromancy, which can be linked with one of the curiosities that the church banned.

The first act starts with a soliloquy of Faustus:

Faustus in his study

FAUSTUS Settle thy studies, Faustus, and begin

To sound the depth of that thou wilt profess.

Having commenced, be a divine in show,

Yet level at the end of every art,

And live and die in Aristotle's works.

Sweet Analytics, 'tis thou hast ravished me!

[He reads] 'Bene disserere est finis logices. ${ }^{4}$

In his soliloquy he addresses himself as 'thou', uses the words 'thy studies' which indicate his split self, his alienation from the self, the inner chaos he is in, his problem in recognizing his self. Faustus' inner turmoil is emphasised through addressing himself in the second person. Like the chorus' framing the narrative and establishing order in disorder, the second person voice controls Faustus' split self by alienating himself from his rebellious side, and distancing himself. Marlowe emphasizes this split self throughout the play: 'Now, Faustus, must thou needs be damned?/Canst thou not be saved?/.../'Abjure this magic, turn to God again!,"5 While the first person rejects God's authority, the second voice warns him to turn to God. However since Faustus is already 'swoll'n with cunning of a self-conceit' as Prologue informs us, it is impossible for him to turn to God.

In his soliloquy, there are also references to male authority, canon which is a compilation of all mediating texts that prevent him from reaching the sources from first hand. Faustus continually cites this male canon, Latin texts and uses quotations from the texts in their original languages. English is not adequate enough to express the ideas of these books, thus, we see the other languages' sovereignty over English. These languages' sovereignty over English cannot dominate Faustus because they are all the words of the mediators and they include ambiguities that confuse Faustus. For example, according to Dr. Faustus, there is ambiguity in Jerome's Bible: 
Jerome's Bible views it well:

(He reads) 'Stipendium peccati mors est.'Ha!

'Stipendium', etc.

The reward of the sin is death? That is hard.

(He reads) 'Si peccasse negamus, fallimur

Eet nulla est in nobis veritas.'

If we say that we have no sin,

We deceive ourselves, and there is no truth in us.

Why then belike we must sin,

And so consequently die.

Ay, we must die an everlasting death.

What doctrine call you this? Che sera, sera:

What will be, shall be; Divinity, adieu!

(He picks up a book of magic)

These metaphysics of magicians,

And Necromantic books are heavenly. ${ }^{6}$

Faustus does not say that it is God's Bible, instead he says Jerome's Bible. According to the Puritan view, the Bible reflects the words of God. However, since he says 'Jerome's Bible', he feels no direct relation with God. He reads the Bible from Jerome's interpretation of the Bible. The same is valid for Justinian. If Justinian has written the Christian Law, where is God's law? These men stand between man and God and they must not interfere between man and God according to the view of Puritans. These mediators overwhelmed the words of God. Thus, they are not reliable texts since mediators interpret them. However, the ambiguity Jerome's Bible creates in the mind of Faustus does not stimulate him to rewrite or reinterpret the Bible with his own words due to fear. Instead he leaves the Bible to Jerome saying 'What will be, shall be', being not concerned any more with the ambiguity of both this life and also the other life. Thus, we are then again faced with textual control. Neglecting the idea of Heaven and Hell, in spite of the fact that he desires to learn the secrecies of both, he only emphasizes the ambiguity of the phrase: 'The reward of the sin is death?' Faustus stands for the individual will and takes responsibility for his sins by challenging and leaving the Holy Book to Jerome and taking necromantic books his hands. Mediators' using different languages necessitate the translation of these texts; one cannot reach them from the original. God seems to be absent and always represented. If Faustus could reach God, his place would be determined in God's world; however, he can only approach God through mediators, as in the case of Jerome's Bible. It is stressed that Faustus knows Italian, Latin and Greek; he not only studied law, medicine, theology but also logic. Education, which awakened his scholarly consciousness in a wider sense of learning and intellectual life, putting the emphasis upon the 
individual mind, arouses dissatisfaction with what is learnt through scholarly books in Faustus. While he is emphasizing his dissatisfaction, and he is mocking the scholarly books, we sense the fear that he feels in his inner turmoil.

Before the appearance of the scholars who are the embodiment the kind of approach to scholarly knowledge that was very respectable in the Renaissance, his friends Valdes and Cornelius appear. Faustus is aware of the fact that as a scholar, he is only a man who cannot make men to live eternally or raise the dead to life again, so he provides reasons for his applying magic, justifying the reasons to his dearest friends Valdes and Cornelius. Valdes is reminiscent of Juan de Valdés who was a Spanish religious writer of the sixteenth century. Since Spain was a Catholic country, Marlowe stresses that this Valdes is German Valdes to emphasize this Valdes is protestant. Marlowe's transforming a Spanish religious writer to a Teutonic Protestant designates to the reader the interchangeability of political and religious dogmas and the chaos that lurks as a consistent possibility. On the other hand, Cornelius Agrippa was a magician and Cabbalist and lived between the years of 1486 and 1535 and his defence of witches during his lifetime posits him on the side of chaos and against conventional authorities.

Valdes, sweet Valdes, and Cornelius,

Know that your words have won me at the last

To practice magic and concealed arts.

Philosophy is odious and obscure;

Both law and physic are for petty wits;

'Tis Magic, Magic hath ravished me.

Then, gentle friends, aid me in this attempt. ${ }^{7}$

Although Marlowe's Dr. Faustus is presented as a scholar who has intellectual curiosity, he goes beyond intellectual curiosity to avoid the boundaries of the exterior world. However, it is controversial whether he really goes beyond the boundaries or not, the situation is ambiguous. This ambiguity, the struggle between opposing forces occurs throughout the play. He does not really reach power since he only orders Mephistopheles to actualise his desires though his requirements are not fully fulfilled.

Faustus rebels with immature arrogance against traditional knowledge, its borders determined by Orthodox Christian beliefs. Dissatisfied with traditional learning, Faustus offers his soul to Mephistopheles despite the warnings of [the] Good Angel: 'O Faustus, lay that damned book aside/And gaze not on it, lest it tempt thy soul/And heap God's heavy wrath upon thy head!/Read, read the Scriptures. That is blasphemy. ${ }^{8}$ These words make Faustus passive whereas, Mephistopheles' words are tempting, leading him towards action, which will help him to prove his existence. [The] Good Angel only leads Faustus to read what is already written thus, the rebellion becomes more attractive for him. While [the] 
Good Angel refers to God, [the] Bad Angel uses the word 'Jove', ${ }^{9}$ introducing the Pagan element and denying the supremacy of the Christian deity. [The] Good and [the] bad angels in the play represent his split self, and the binary oppositions that the individual is imprisoned in the society in which Faustus lives. The more universal conflict between God and Satan is mirrored in the duality of voices that Faustus hears from the angels attached to him. Marlowe's text, perhaps unwittingly reveals to us the impossibility of 'good' existing in a world where 'evil' is absent.

In conclusion, as the text analysis of Dr. Faustus offers, Faustus' split self, his alienation from the self, and the inner chaos he is in, his problem in recognizing his self results in the difficulty of classifying him either as a hero or a villain. While the Renaissance age allowing going further, on the other hand punishment is unavoidable due to trespassing the boundaries. Thus, reconciliation cannot be achieved in Faustus' deeds. However, two centuries later, ambitious strife for power to emulate God is tolerable and is, in a way, rewarded since knowledge serving the deeds and intellectual self-seeking and progressive intellectual mind that are all characterized by reason are the central ideas of Goethe's age.

\section{Notes}

${ }^{1}$ This chapter is part of my unpublished phD thesis entitled 'The Faustus Myth in the English Novel'.

${ }^{2}$ E. Kessler, et al., The Cambridge History of Renaissance Philosophy, Cambridge University Press, 1988, p. 310.

${ }^{3}$ C. Marlowe, Doctor Faustus and Other Plays, D. Bevington \& E. Rasmussen (eds), Oxford University Press, Oxford, 1995, Prologue, lines 15-27.

${ }^{4}$ Ibid., 1.1, lines 1-6.

${ }^{5}$ Ibid., 2.1, lines 1-8.

${ }^{6}$ Ibid., 1.1 , lines $36-50$.

${ }^{7}$ Ibid., 1.1, lines 99-105.

${ }^{8}$ Ibid., 1.1, lines 69-72.

${ }^{9}$ Ibid., 1.1, line 76.

\section{Bibliography}

Graves, R., The Greek Myths. Moyer Bell Ltd., 1955.

Kessler, E., et al., The Cambridge History of Renaissance Philosophy. Cambridge University Press, 1988.

Marlowe, C., Doctor Faustus and Other Plays. Bevington, D. \& Rasmussen, E. (eds), Oxford, Oxford University Press, 1995. 
Seyda Inceoglu received her BA degree in English Language and Literature from Ege University and her MA degree from Pamukkale University, Turkey. In July 2008, she completed her PhD in the same field at İstanbul University, with her dissertation entitled The Faustus Myth in the English Novel. Her publications include articles on the Victorian and Postmodern English Novel, English Drama, the Faustus Myth and its representations in the English Novel. Seyda Inceoglu is currently working as an Assistant Professor of English Language and Literature at Pamukkale University. 


\section{PART II}

Doubles, Criminals and Nicholas Dyer 



\title{
A Complicated Matter of Villainy: Mr. Hyde in R. L. Stevenson's 'The Strange Case of Dr. Jekyll and Mr. Hyde'
}

Ömer $\ddot{O} \breve{G} \ddot{U} N C ̧$

\begin{abstract}
Literary history has always witnessed the struggle between the hero and the villain. Although the villain creates uneasiness with his attitude against the good people, this figure is used by writers to emphasize the significance of contradictory concepts. As opposed to the novels emphasizing realism, Robert Louis Stevenson writes 'The Strange Case of Dr. Jekyll and Mr. Hyde' to appear with a new approach in literature based on science fiction. Mr. Hyde, the product of experiments conducted by the mad scientist Dr. Jekyll, thus comes to the fore as a villain and stands for Jekyll's subconscious. Victorian society is well known for its strict moral codes suppressing the individual. Suffocating under this social pressure, Dr. Jekyll looks for a solution that would enable him to feel independence without the restraints of his conscience. Therefore it may be stated that no matter how Mr. Hyde acts in opposition to the Victorian norms and social expectations of conformity, the villain is metaphorically created by that society. This situation complicates the definition of villain as to his nature: is he a good or a bad character? The protagonist enjoying his freedom at the beginning cannot cope with his evil twin at the end; so that, Dr. Jekyll's twin turns into a tragic villain leading to the death of his creator. Stevenson at the same time comes up with a serious discussion of the Victorian society against the individual. So, this paper aims at a critical reading of the novel in line with the villain figure focusing on his social and literary status as well as the changing definitions of villainy.
\end{abstract}

Key Words: Villain, evil twin, mad scientist, Victorian hypocrisy, subconscious.

$* * * * *$

A general outlook into the $19^{\text {th }}$ century shows that the era is characterized by a continuous process of change in economic, political, scientific and social aspects throughout the early and mid-Victorian periods. Although the Victorians on the whole tried to create a stable social structure enabling control on the individuals, due to these fundamental changes, it gradually turned out to be more and more difficult to restrict people in a stabilized social code; thus individuality and desire for freedom came to the fore with a questioning attitude in the following decades. However under the strict social and moral codes, it was not so easy for the individual to challenge the whole established order explicitly on his own. So a drastic crash between the society and the individual was unavoidable.

When Stevenson wrote his novella 'The Strange Case of Dr. Jekyll and Mr. Hyde' in 1886, he reflected the social and literary circumstances in an implicit and 
suggestive manner making it possible to approach this work from two main perspectives. On the literal level, the shocking result of Dr. Jekyll's experiment creates a villain portrayed as a threat to the whole society. Mr. Hyde is a monster living independent of all the norms that regulate everyday life for a proper Victorian man. In other words, he is the wicked hero of that gothic setting. Apart from this literal aspect, on a metaphorical level, the novella may at the same time be interpreted as the story of an individual oppressed by the society and who has to find a way out for the fulfillment of personal desires. Thus it may be regarded as the story of the mad scientist who discovers his evil twin that has already been living in his subconscious as a part of his identity, yet would not be allowed to come to the surface. This paper therefore aims at studying the novella as a metaphor that stands for the struggle between the individual and the society, looking into the split identity of Victorian man in different aspects.

Irving Saposnik states that

Victorian man was haunted constantly by an inescapable sense of division. As rational and sensual being, as public and private man, as civilized and bestial creature, he found himself necessarily an actor, playing only that part of himself suitable to the occasion. ${ }^{1}$

This attitude of leaving the real self aside and assuming a socially acceptable standpoint paved the way for Victorian hypocrisy that came to characterize the society in general. The people could no longer hold their genuine identity on the foreground as long as it contradicted the norms. On this point, in relation to the novella it may be further argued that this division in Victorian era had turned out to be a way of life. In this respect, if Hyde is to be considered as a being hidden in Jekyll's subconscious, he may be called 'the shadow self of a half man'. ${ }^{2}$ Therefore it may be asserted that what produces Mr. Hyde is Victorian hypocrisy itself. The social structure is based on the individual's lack of freedom for the sake of following morality firmly. That is why Dr. Jekyll who leads a respectable lifestyle in the community nourishes in his subconscious a character like Mr. Hyde who is the personification of all evils.

The idea of respectability is important in understanding the process that created Mr. Hyde. Stevenson uses other characters to emphasize and explain this notion in a typical Victorian environment with suitable personal features. In this respect, both Utterson and Dr. Lanyon in the novella are typical Victorian men whose function is to show the difference between the proper and the improper in terms of manners. As opposed to these symbols of respectability for Victorians, Jekyll is living out of conventions and following his own ways. In his own words, 
the worst of my faults was a certain impatient gaiety of disposition, such as has made the happiness of many, but such as I found it hard to reconcile with my imperious desire to carry my head high, and wear a more than commonly grave countenance before the public. ${ }^{3}$

In line with this foreshadowing, particularly Jekyll's interest in extreme scientific experiments and his challenging attitude towards the rules of his profession turn him into an outcast who goes beyond Victorian limits contrary to Lanyon who is the man of practical concerns and Utterson who adheres to his profession.

The main problem about Jekyll is the other self that grows in his mind as an alternative to the respectable character approved by the community. Hyde, who might be taken as his evil twin, is initially a means of freedom for the oppressed protagonist. Jekyll describes his lifestyle before Hyde as that

it came about that I concealed my pleasures; and that when I reached years of reflection, and began to look round me, and take stock of my progress and position in the world, I stood already committed to a profound duplicity of life. ${ }^{4}$

This duplicity of life mentioned by Jekyll refers to hypocrisy observed in Victorian society. The only way of becoming the real person he wants to be lies in a secret path since he at the same time does not want to be left alone by the community. On the matter of duality, Irving Massey believes that

a common version of the 'double' story presents a character who harbours an alien evil self, or who turns uncontrollably from good to bad. [...] The problems in these situations arise from the unity rather than the duality of character. ${ }^{5}$

Despite the physical duality in appearance, the formation in Jekyll's mind has become a part of his life, which means that insincere Victorian way of life is inherent in his identity. For him, Hyde is not somebody else, but exactly Jekyll's other way of expressing himself in an independent manner. Jekyll continues his confession saying that

though so profound a double-dealer, I was in no sense a hypocrite; both sides of me were in dead earnest; I was no more myself when I laid aside restraint and plunged in shame, than when I laboured, in the eye of day, at the furtherance of knowledge or the relief of sorrow and suffering. ${ }^{6}$ 
In other words, Jekyll clearly embraces his unusual concerns and protects Hyde bringing him forth as a part of his individuality that makes him unique among others. Jekyll's growing awareness about Hyde may be considered as a form of self-discovery.

It was on the moral side, and in my own person, that I learned to recognize the thorough and primitive duality of man; I saw that, of the two natures that contended in the field of my consciousness, even if I could rightly be said to be either, it was only because I was radically both. ${ }^{7}$

It is in fact exactly at this point that science comes to help the scientist in his challenge to the society by becoming two men at the same, though he has to keep the evil side in secret to sustain his respectable status. Although Jekyll is a challenging character, he is not courageous enough to turn his back on the society yet. As all unbearable feelings gradually disappear, we observe freedom in Jekyll's behaviour and conscience, so that he begins to enjoy independence from all restrictive Victorian norms. As regards this shift between the two characters, it may be stated that the good and the evil parts in Jekyll's identity are the same. The challenging man, namely Jekyll, has adopted this duality, considered to be a general criticism on the Victorian lifestyle. For him, this is a natural process, because he has finally found the real self hidden in his subconscious.

For the decade in which the novella was written, it may be argued that social norms had already begun to lose their rigidity at the time because of the social structure that introduced new forms of life together with new social classes and expectations. The long lasting Victorian ideals were on the point of change. In other words, the change in Jekyll towards a more incongruous person reflects these decades to a certain extent. His thoughts following the transformation into Hyde show this condition:

I felt younger, lighter, happier in body; within I was conscious of a heady recklessness, a current of disordered sensual images running like a mill race in my fancy, a solution to the bonds of obligation, an unknown but not an innocent freedom of the soul. [...] The evil side of my nature, to which I had now transferred the stamping efficacy, was less robust and less developed than the good, which I had just deposed. ${ }^{8}$

This happy man who began to experience freedom at an old age shows the reader how urgent and invaluable it is to save himself from social burdens. No matter what the consequences of an experiment are, he ventures this unknown experience to give life to his inner self. Hence it may be argued that since the 
individual had no private space under social oppression in the $19^{\text {th }}$ century, any possible alternative for freedom turns into something worth trying. So 'though pleasure had been suppressed for a long time by the dreary decency that was his life, Dr. Jekyll will enjoy it, after all, in the person of a totally new identity, Edward Hyde'.

In addition to this desire for freedom, another reason that leads to a split identity in Jekyll is the changing definition of gender roles, particularly that of masculinity. In order to understand this shift in the social connotations of the gender notion, the opposing elements against the traditional definitions of masculinity should be taken into consideration. These opposing configurations are on the one hand a political and economic being and on the other hand a biological being. Having a male body is sufficient to be called a man on the biological level; however social expectations that depend on conforming to the norms of strict Victorian society create other requirement to view a male as a real man on the social level. All these economic and social developments, which are also closely associated with the consequences of Industrial Revolution and urban life it created, caused some sort of weakening in the traditional understanding of masculinity together with a stronger understanding of femininity as women began to appear more demanding and conscious in the social scale.

In the context of this gender discussion, it is possible to interpret the relationship between Jekyll and Hyde in a different perspective. At the time, Stevenson himself has also just married, so that the male struggle in the society to protect dominant position with new modes of self-representation in split identities may be linked to the relationship between Stevenson and his wife. In fact, Janice Doane associates Hyde's appearance with the male anxiety that results from a weakening patriarchal order in the late-Victorian period and claims that
if Victorian womanhood is indeed connected with transformation itself, then sexuality and identity are unlikely to remain the fixed categories. [...] 'Jekyll and Hyde' is about a collaboration between the masculine and the feminine that subverts the identity of each. ${ }^{10}$

Therefore, because of the subversion of gender identities, the novella may be regarded as an expression of the identity cohesion that takes place between the newly married couple. A much more feminine male character like Hyde, which might be observed particularly in the depictions of his physical appearance such as his delicate body and small hands that are traditionally female characteristics, embodies both brutal and feminine qualities. Under these new conditions, 'men are said to have feminine perceptions; women are masculine and direct. Men are violent - but women are too'. ${ }^{11}$ Besides, the violence observed in three main incidents that Hyde experiences on the streets may be explained though not be 
justified with his individuality. Violence does not come forward as it appears, but it is implicitly connected to the theme of individuality. Despite this gender interpretation of the relationship between Jekyll and Hyde, it is clear that the desire for individuality and personal freedom remains unchanged. Hyde clearly becomes the symbol of individuality for Jekyll. Therefore this metamorphosis observed in Jekyll is also a reference to the newly defined male roles that are shaped in accordance with the social conditions of that period. Stevenson's biographical elements in his marriage and the influence of his much older wife beside the social criticism of the era are put together in a creative way.

With regard to the theme of villainy in 'Jekyll and Hyde', one last theme to be touched upon is that of mad scientist. Milton Millhauser claims that

scientists were a rather unfamiliar race of beings. There were not many of them; the significance of their work, except when they stirred up an occasional theological storm, seemed remote; certainly they did not touch men's lives intimately and powerfully as lawyers and politicians, the military and the clergy did or might. ${ }^{12}$

That is why in the novella we have Dr. Jekyll as the mad scientist unlike for instance Utterson or his kinsman Enfield. In fact, the only person that could endure Jekyll's transformation albeit questionably is another colleague, namely Dr. Lanyon.

This repeated reference to doctors is also connected to another social reality, which arouses fear in the public. Contrary to the contemporary methods, medical practices in the past may have deserved this infamy. The fact that doctors have always been associated with terrible pain, unknown substances and forbidden actions for the sake of medical research contributes to this reaction among common people. On the same matter, Christopher Toumey draws attention to the hazardous effects of this tendency in literature and argues that 'they convey the argument that rationalist secular science is dangerous and their principal device for doing so is to invest the evil of science in the personality of the scientist' (411). ${ }^{13}$ Clearly these gothic and anti-rationalist elements in literature constitute a reaction to the realist tradition in literature. Nonetheless the evil side in science is continuously emphasized. Therefore it is necessary to make a clear distinction between science fiction and mad scientist stories. On the one hand, science fiction supports science and technology presenting them as a means of increasing living standards. On the other hand, mad scientist stories dispraise science and show it as a threat to social welfare. In this respect, 'Jekyll and Hyde' is the story of a mad scientist rather than an example of science fiction. At the end, it brings an individual to the point of self-destruction and threatens other people all this while. Dr. Henry Jekyll, despite his scientific methodology, is depicted as an opponent to rational science with 
ambiguous, mysterious and illogical experiments, which means that Victorian rationality is still highly influential on a narrative that sets off with the claim of challenging it.

In conclusion, it may be argued that 'Jekyll and Hyde' as a late $19^{\text {th }}$ century novella explores social, scientific, literary, economic and gender problems appertaining to that period in a definitely suggestive manner. Stevenson seems to have achieved his purpose of bringing different matters of his age to discussion without taking sides with any of his characters. Beside the life-like representation of individuality, the society is reflected to the full extent with types that may stand for any Victorian man and that are separated with their particular qualities. Therefore the novella may be regarded as an eligible representation of the lateVictorian era.

\section{Notes}

${ }^{1}$ I.S. Saposnik, 'The Anatomy of Dr. Jekyll and Mr. Hyde', Studies in English Literature, 1500-1900, Vol. 11, August 1971, p. 716.

${ }^{2}$ Ibid., p. 717.

${ }^{3}$ R.L. Stevenson, 'The Strange Case of Dr. Jekyll and Mr. Hyde', 'The Merry Men' and Other Tales and Fables, Wordsworth Classics, London, 1999, p. 41.

${ }^{4}$ Ibid., p. 42.

${ }^{5}$ I. Massey, 'The Third Self: Dracula, 'Strange Case of Dr. Jekyll and Mr. Hyde' and Méerimée's Lokis', The Bulletin of the Midwest Modern Language Association, Vol. 6, Autumn 1973, p. 57.

${ }^{6}$ Stevenson, op. cit., p. 42.

${ }^{7}$ Ibid., p. 42.

${ }^{8}$ Ibid., p. 44.

${ }^{9}$ M. Miyoshi, 'Dr. Jekyll and the Emergence of Mr. Hyde', College English, Vol. 27, March 1966, p. 473.

10 J. Doane, 'Demonic Disturbances of Sexual Identity: "The Strange Case of Dr. Jekyll and Mr/s Hyde", NOVEL: A Forum on Fiction, Vol. 23, Autumn 1989, p. 63.

${ }^{11}$ Ibid., p. 65.

${ }^{12}$ M. Millhauser, 'Dr. Newton and Mr. Hyde: Scientists in Fiction from Swift to Stevenson', Nineteenth-Century Fiction, Vol. 28, December 1973, p. 300.

${ }^{13}$ Ibid., Nineteenth-Century Fiction, Vol. 28, December 1973, p. 411.

\section{Bibliography}

Doane, J., 'Demonic Disturbances of Sexual Identity: "The Strange Case of Dr. Jekyll and Mr/s Hyde"'. NOVEL: A Forum on Fiction. Vol. 23, Autumn 1989, pp. 63-74. 
Massey, I., 'The Third Self: Dracula, 'Strange Case of Dr. Jekyll and Mr. Hyde' and Méerimée's Lokis'. The Bulletin of the Midwest Modern Language Association. Vol. 6, Autumn 1973, pp. 57-67.

Millhauser, M., 'Dr. Newton and Mr. Hyde: Scientists in Fiction from Swift to Stevenson'. Nineteenth-Century Fiction. Vol. 28, December 1973, pp. 287-304.

Miyoshi, M., 'Dr. Jekyll and the Emergence of Mr. Hyde'. College English. Vol. 27, March 1966, pp. 470-480.

Stevenson, R.L., 'The Strange Case of Dr. Jekyll and Mr. Hyde', 'The Merry Men' and Other Tales and Fables. Wordsworth Classics, London, 1999.

Ömer ÖĞÜNÇ is a research assistant in Hacettepe University, Department of English Language and Literature. He is interested in English novel and translation studies. Currently, he continues his $\mathrm{PhD}$ researches on $19^{\text {th }}$ century English novel. 


\title{
What is a Villain? Thackeray's Play with the Reader's Perception in Catherine and Barry Lyndon
}

\author{
Ellen Redling
}

\begin{abstract}
Critics usually focus on melodramatic villains in Victorian fiction, especially in Newgate Novels such as Dickens' Oliver Twist or Bulwer-Lytton's Ernest Maltravers, but I intend to shift the focus to the ways truly villainous, unromantic characters are created. Authors like Thackeray experimented with the technique of guiding the readers' sympathies, knowing that readers usually either like the morally acceptable villain or the sensational one. But why not establish a countermodel and find out what a villain realistically is? I argue that Thackeray in Catherine and Barry Lyndon through the use of irony avoids sensationalism and plays with the reader's perception in a way that renders the villains most interesting when they are most morally unsympathetic, most insane, and whenever they surpass initially more competent villains. In Catherine, Thackeray sets up a rivalry between a biased, misogynistic narrator-persona and the protagonist, with the former constantly trying to understate and undermine the latter's strength. Only when Catherine slips through the narrator's tight grasp towards the middle and end of the novel can her villainous power become visible. In Barry Lyndon, the protagonist also appears weak at the beginning and stronger at the end, when he is no longer influenced by mentor figures. He himself is the main narrator, and the increasing use of both hyperbole and understatement - which also indicates his growing madness - serves on the one hand to make him more fascinating, but on the other hand prevents sensationalism. By focusing on the idea of competition in crime we can also reject the moralising discussion that still governs the analysis of these two works.
\end{abstract}

Key Words: Thackeray, $19^{\text {th }}$ century, Victorian, satire, irony, villain, villainess, gender, anti-romance, anti-Newgate.

$* * * * *$

In this chapter I would like to discuss two early works by the Victorian writer William Makepeace Thackeray and their very particular villains. The novels Catherine and Barry Lyndon have in fact much in common. Both are satires and both are set in the $18^{\text {th }}$ century, a time that the author very much liked precisely because of its penchant for this special mode. However, the butts of Thackeray's early satires are to be found in the first half of the $19^{\text {th }}$ century. He criticises readers and writers of genres, which are in vogue at the time, mainly of the Newgate Novels. This type of fiction was exceedingly popular in the first half of the $19^{\text {th }}$ century and was based, to a great or lesser extent, on real stories of criminals who 
were sent to Newgate prison. The stories were taken from the so-called Newgate Calendar. Thackeray found that in these novels crimes were glorified and that either villains turned out to be good - such as Nancy in Dickens's Oliver Twist - or that, vice versa, good characters showed themselves to be villainous, as in BulwerLytton's Ernest Maltravers. In Catherine and Barry Lyndon, Thackeray's goal is therefore an attack on romance and its hero-worship and melodramatic structures. True, he at this point has yet to write his great 'Novel Without a Hero' - Vanity Fair. However, it is really here, in his early works, that he most radically promotes the concepts of anti-romance and anti-heroism. He achieves this, as I would like to show, not only through a direct display of the weaknesses of the works of other writers, but also by creating something new: a novel type of villain that is as antiromantic as s/he can get: Catherine is a low, vain barmaid, Barry a self-deluded Irish rogue. The narrator-persona which Thackeray uses in Catherine is a disrespected Jew by the name of Solomons, himself an underdog in the business of crime. In Barry Lyndon, Barry himself is the main narrator, whose aim is to aggrandise his criminal achievements. I have selected excerpts from these novels in which either the theme of envy between villains regarding who is 'the baddest man in town' or that of proving oneself as a master criminal against one's former mentor is used to turn Catherine and Barry from initial weaklings into true but nonsensational villains who outdo the merely melodramatic villains of the contemporary Newgate Novels. In each case, I argue, Thackeray uses ironic rhetorical techniques that work against the narrator's intent and self-centredness, avoid sensationalism in the Newgate style and at the same time create an appreciation of the new-found strength of the villain. By focusing on the idea of competition in crime we can also reject the moralising discussion that still governs the analysis of these two works.

In Catherine Thackeray follows the Newgate Novels' method of treating all the crimes that the Newgate Calendar lists for a specific criminal, but unlike these novels he opts for irony instead of 'true romance' and allows himself the freedom to rearrange and re-evaluate the crimes. In the novel, Cat, together with Doctor Wood - alias Brock - and her son, who both live with her, kills her husband Hayes in order to be free for a newly-returned count. The body is dismembered and thrown into the Thames. However, the murder is discovered, since Hayes's head, which was stuck on a pole, is recognised, and Catherine is burned at the stake. Wood and Tom are hanged.

In order to uncover Thackeray's ironic rhetorical technique, the reader needs to realise that, first of all, the narrator-persona Solomons is greatly responsible for some of the changes made to the original account, and that, more importantly, his presentation of Catherine's crimes is biased by his own inferiority complex and his envy. The text reveals several signals of his attempt to denigrate Catherine by belittling her strength as a woman and villainess and by invalidating her uniqueness. 
For example, after setting the orphaned protagonist up as a Becky Sharp-like little temptress, who has 'half-a-dozen lovers in the village'1 and attracts many customers, Solomons immediately deflates her: 'O woman, lovely woman! What strong resolves canst thou twist round thy little finger!'2 Solomons looks down upon the woman Catherine who believes she can equal truly criminal men. He continues in this vein when he reports about the stupidity of this woman to fall in love with Count Galgenstein, who mistreats her: 'The woman loved him, that was the fact; $[\ldots]$ and $[\ldots]$ only liked him the better for the brutality which she received at his hands'. ${ }^{3}$ Significantly, Galgenstein and Cat's love for him lack any basis in the original account and thus - rather than representing a real motive for the later killing of her husband, as Sheldon F. Goldfarb sees it ${ }^{4}$ - seem to be specifically invented by Solomons to put Catherine down. In addition to implying the inferiority of women in general through his own narratorial comment, Solomons repeatedly compares her competitive inferiority to that of more shining male criminals, such as Galgenstein and Brock. The achievements of these two 'heroes' are mentioned at the beginning of the novel and thus set an example with which Catherine has to compete. Also, when she is confronted with the cruel Galgenstein, Catherine is presented as being at the latter's mercy. She is not capable of killing him, but simply turns 'pale', 'whimper[s]' and 'crie[s]': 'O count, forgive me, forgive me!" This whimpering clearly has a negative connotation. Taken as a series, the above-mentioned references do not point into the direction of a less guilty and therefore 'charming ${ }^{6}$ protagonist. Rather, they indicate that Thackeray deliberately chose a woman who is first presented as inferior to men but then outdoes them in terms of criminal potential, in order to ridicule the whole Newgate genre. The following excerpts fit into this competitive context.

The first of these is the scene in which Catherine mistreats her husband Hayes, whom she married after Galgenstein left her. The narrator denounces her: she "had obtained a complete mastery over her lord and master ${ }^{7}$ and she demands her child back and urges her husband to comply. Solomons uses the situation to insert his misogynistic evaluation: '[...] the reader, high or low, knows that when Mrs. Reader desires a thing, have it she will'. ${ }^{8}$ He slyly alludes to a typical husband's control over the possessions in the house. No male reader would permit his 'Mrs. Reader' to demand a thing and be able to get it if the husband disagrees. Solomons reveals his male envy over the wife's control of things. In Chapter 8, Solomons continues in this line: Hayes 'trembled before Mrs. Hayes [...] The woman heartily scorned, and spit upon her husband, who fawned upon her like a spaniel'. ${ }^{9}$ By adding these insults, Solomons tries to increase the reader's dismay at and horror of this woman. In fact, however, he discloses her strength. While she was the weak one in her relationship with Galgenstein, she is now the powerful one in her marriage with Hayes. Recognising her growing independence, Solomons then allows Brock to step in as a 'hoary old tempter'. ${ }^{10}$ However, the narrator is not as clear about Cat's subsequent lack of power as it might seem. He gets entangled in 
contradictions. For instance, while he states that Brock encourages Hayes's fear of his wife, he admits: '[...] in truth, that unfortunate creature [Mr. Hayes] had no occasion for incitements from without, to keep up the dreadful state of terror and depression into which he had fallen'. ${ }^{11}$ He thus reveals that Brock is in fact not needed and Cat is enough to make Hayes afraid. Furthermore, Solomons even inadvertently increases Cat's 'standing' as a brute, by turning the real John Hayes into the fictional figure of a usurer and weakling. Both Goldfarb and Frederick C. Cabot claim that by blackening the victim, Catherine appears less guilty and therefore more morally acceptable. ${ }^{12}$ The decrease in culpability is precisely what Solomons intended, not, however, for moral reasons but because of the competition between Cat and himself. However, he is outwitted by his own strategy and the damage is done. Catherine the underdog has overpowered her male competitors, gained back what belonged to her, especially her child, and later is a party in the killing of her husband. Criminal success dismantles Solomons's incriminations of Catherine's social cruelty, i.e. her disrespect for her husband's rights. The rhetorical technique that Thackeray uses is to have Solomons enviously understate Catherine's criminal skill, but through forcing him to report her success according to the Newgate Calendar, he ironically raises Catherine's reputation with the reader.

The protagonist as he appears in the first part of Barry Lyndon has been similarly misrepresented by critics as an 'almost sympathetic young scapegrace', who then changes into a 'dyed-in-the-wool villain'. ${ }^{13}$ But if we submit that Barry, the narrator, aims to aggrandise his own achievements in his autobiography and sets up a situation in which Barry, the protagonist, is first shown as an inexperienced apprentice of various villains and then as an accomplished criminal, we must again question these critics who turn to moral categories. For, like Cat he appears weak at the beginning, and stronger at the end. Furthermore, Thackeray allows him to either falsely augment his criminal achievements or affect a noncriminal intent, but both the implied hyperbole as well as the understatement again prevent sensationalism and 'dyed-in-the-wool' villainy. The ironic techniques undercut the typical means and effects of the Newgate Novel and yet allow Barry to enjoy a certain feeling of success after his failures in life. The avoidance of sensationalism was carried over to all of Thackeray's later works.

Barry Lyndon has three mentors in his criminal career, first his mother, who teaches him to take on roles, aspire to wealth and fight duels for his honour, then Fagan, a soldier, who nourishes Barry's unfounded feelings of military greatness, but who soon dies in battle. His final mentor is his uncle, who rescues him from the soldier's career and instead instructs him on how to make money by gambling and by marrying a wealthy woman. Barry is a good apprentice and obeys his uncle, in fact succeeds in marrying Lady Lyndon, from whom he takes his name, but afterwards acts more independently. It is from this point onwards that his cruelty and madness become apparent. Given the means and the power, he turns from a 
weakling, who frequently cries and thinks about suicide, ${ }^{14}$ into a tyrant in his own home. He cheats on his wife, severely mistreats both her and her son Bullingdon and squanders all their money. On the one hand, his success turns him into a greater braggart and on the other his understatements reveal certain wariness. Both rhetorical techniques are used to undercut the horror and potential sensationalism of his acts. Thus, in Chapter 1 of Part 2 he inadvertently reveals these weaknesses. He dreams of becoming a viscount and spends an enormous amount of money on transforming his 'Norman castle' into a 'Greek temple', to which he adds 'genteel French style' gardens. ${ }^{15}$ These statements suggest both an aggrandising dream and a deliberate attempt to make his actions appear as cultural embellishments. Likewise his defensiveness is revealed when he madly claims that his violence towards his wife is meant to do good: 'Lady Lyndon was a haughty woman, and I hate pride, and I promise you that [...] I overcame this vice in her'. ${ }^{16}$ Barry affects to be 'only a severe and careful guardian over a silly, bad-tempered and weakminded lady'. ${ }^{17}$ He blames alcohol for his wrong-doings: 'For three years I never struck my wife but when I was in liquor. When I flung the carving-knife at Bullingdon I was drunk [...]'. ${ }^{18}$ Later, he hits Bullingdon with a horsewhip and drives his wife into madness. His insanity is also revealed when he lets the reader believe he is a good father to his own child, Bryan, who, however, upon his death mentions that Bullingdon treated him better than he did. ${ }^{19}$ Barry blames all his failures in life on either fate - e.g. when his son $\operatorname{dies}^{20}$ - or women (woman is generally 'at the bottom of [mischief]'), ${ }^{21}$ or on others. A double irony is used when one of his understatements turns out to be the truth: Just like he says, he is indeed not the great villain 'Bluebeard' that other characters and, we can add, the critics take him to be. ${ }^{22}$ Instead, as the reader knows, he is a common rogue who maltreats his family. However, in view of defeat he is happy to compare himself to Julius Caesar, ${ }^{23}$ and the hyperbole again becomes clear. As a victim, he thinks he is grand, which provokes amusement and fascination; but as a perpetrator he dislikes sensationalism - just like the recipient is supposed to do. The reader is unsure whether to trust him when he says that Lady Lyndon still loves him, although she fled from him, and takes his side against her own son. Like Catherine, Barry has to suffer for his crimes. He is imprisoned and dies a pauper. What strikes the reader is the author's creation of a dazzling criminal figure proud of himself and yet wary, a self-made man anticipating his later self-made woman, Becky Sharp. But this achievement is due to the contrasts created by the ironic rhetorical techniques, of hyperbole and litotes. The rhetorical play avoids sensational horror and gives some credit to this criminal climber. Overall, the contrasting of the female heroine with renowned but less efficient male criminals in Catherine and the setting off of a finally independent criminal from his tutors permit Thackeray to avoid moral discussions and rather lead a literary battle against unrealistic and illusionary presentations of criminals in the Newgate style. 


\section{Notes}

${ }^{1}$ W. Thackeray, Catherine: A Story by Ikey Solomons, Esq. Junior, W. Thackeray \& S. Goldfarb (eds), University of Michigan Press, Ann Arbor, 1999, p. 6.

${ }^{2}$ Ibid.

${ }^{3}$ Ibid., p. 22.

${ }^{4}$ S. Goldfarb, 'Historical Commentary', Catherine: A Story by Ikey Solomons, Esq. Junior, W. Thackeray \& S. Goldfarb (eds), University of Michigan Press, Ann Arbor, 1999, p. 141.

5 Ibid., pp. 31-32.

${ }^{6}$ Goldfarb, p. 140

${ }^{7}$ Ibid., p. 69.

${ }^{8}$ Ibid.

${ }^{9}$ Ibid., pp. 79-80.

${ }^{10}$ Ibid., p. 102.

${ }^{11}$ Ibid., p. 107.

${ }^{12}$ F. Cabot, 'The Two Voices in Thackeray's Catherine', Nineteenth-Century Fiction, Vol. 28, No. 4, 1974, p. 414. See also Goldfarb, p. 140.

13 J. McMaster, Thackeray: The Major Novels, Manchester University Press, Manchester, 1971, p. 188.

${ }^{14}$ W. Thackeray, Luck of Barry Lyndon: A Romance of the Last Century: By FitzBoodle, E. Harden (ed), University of Michigan Press, Ann Arbor, 1999, pp. 26 \& 50 .

${ }^{15}$ Ibid., p. 182.

${ }^{16}$ Ibid., p. 173.

${ }^{17}$ Ibid., p. 179.

${ }^{18}$ Ibid., p. 184.

${ }^{19}$ Ibid., p. 208.

${ }^{20}$ Ibid., p. 205.

${ }^{21}$ Ibid., p. 1.

22 Ibid., p. 202.

${ }^{23}$ Ibid., p. 209.

\section{Bibliography}

Cabot, F., 'The Two Voices in Thackeray's Catherine'. Nineteenth-Century Fiction. Vol. 28, No. 4, 1974, pp. 404-416.

Goldfarb, S., 'Historical Commentary'. Catherine: A Story by Ikey Solomons, Esq. Junior. Thackeray, W. \& Goldfarb, S. (eds), University of Michigan Press, Ann Arbor, 1999. 
McMaster, J., Thackeray: The Major Novels. Manchester University Press, Manchester, 1971.

Thackeray, W., Catherine: A Story by Ikey Solomons, Esq. Junior. Thackeray, W. \& Goldfarb, S. (eds), University of Michigan Press, Ann Arbor, 1999.

- The Luck of Barry Lyndon: A Romance of the Last Century: By Fitz-Boodle. Harden, E. (ed), University of Michigan Press, Ann Arbor, 1999.

Ellen Redling is a lecturer in English literature at the University of Heidelberg. In 2008 she co-edited Non-Standard Forms of Contemporary Drama and Theatre (Trier: WVT). Her fields of research include Victorian literature, Gothic literature, as well as medieval and contemporary drama. She is currently writing her dissertation on Thackeray. 



\title{
The Double in Poe and Dostoevsky: The Descent into the Subconscious
}

\author{
Ekaterina Yasko
}

\begin{abstract}
The idea of the Double is undoubtedly a cross-cultural concept; moreover, it is a philosophical phenomenon for it interweaves with duality as one of the basic features of existence itself. Although the notion of the Double dates back to ancient mythology, it is still the $19^{\text {th }}$ century when it received the most vivid artistic embodiment. One cannot but admit a close affinity between Edgar Poe and Fyodor Dostoevsky in their frequent use of the Double image to render visible the idea of a split, a mental discord in the hero's mind and the fineness of the line that distinguishes sanity from insanity. This chapter is aimed at tracing the two great masters' points of intersection in the portrayal of the human mind as one, capable of the engendering of the Double. Poe and Dostoevsky appear close as their penetrative analysis of the depths of the human mind is very much the same. In this respect their works proved to be innovative for their epoch. They anticipated such ideas as contradiction and transgression that became the dominant principles of human behaviour proclaimed in the postmodern tradition, with its revelation of concealed subtexts and contradictions. By portraying the Double, Poe and Dostoevsky undermined the very notion of the individual self, of an ontologically complete self, questioning the boundaries of the norm in its conventional understanding. Therefore it would be of interest not only to trace the origins and the meaning of the image of the Double in Dostoevsky's novel of the same name and in Edgar Poe's 'William Wilson', but also to reveal the features of their outlook that turned out to make a profound impact on the subsequent literary and philosophical tradition.
\end{abstract}

Key Words: The double, duality, Poe, Dostoevsky.

$$
* * * * *
$$

The phenomenon of the Double origins from the appearance and the development of the idea of 'the other world', the archaic division of the world in human consciousness into the space of life and that of death, and in the myths of the human soul as a double of a person. Paul Carus states in 'The History of the Devil' notices:

This world of ours is a world of opposites. There is light and shade, there is heat and cold, there is good and evil, there is God and Devil. The dualistic conception of nature has been a necessary phase in the evolution of human thought. ${ }^{1}$ 
Such inherent duality is a deeply philosophical problem since the 'binary system' is one of the basic characteristics of the human existence in general. One can even say that a person is a fatally dual creature, fatally contradictory.

The phenomenon of the Double in fiction implies not only a significant symbolic meaning or rather meanings, but, as Lawrence Porter notices in 'The Devil as Double in the Nineteenth-Century Literature', doubling is 'the generative principle of narrative'. ${ }^{2}$ The protagonist believes that his 'quest for reunion' with his double can bring him wholeness, which leads however to a further division in the hero's mentality and is reflected on the level of the narration.

In fiction the idea of the double was developed in the Romantic context, which was conditional upon the changes of the epoch: there was a need for the replacement of the moral paradigm, the new ideals emerged, causing a need for guiding lines concerning the new structure of the moral consciousness. The original duality acquires in Romantics' understanding a new, symbolic character. The doubling becomes essential not only for the plot but also as a method of structuralizing of the narration. It is realised in the way of solving the conflict, in the style of the narration, in the symbolic paradigm.

The Romantics showed that wearing a mask goes against with the real 'self' and leads to the most tragic consequences. Thus the hero of Dostoevsky's 'The Double', being a 'little man', a man 'of the underground', realises the hypocrisy and pretence of the world one has to survive in and his own absolute helplessness in it:

I am simply enunciating a theory, that is, I am advancing the idea, Anton Antonovitch, that persons who wear a mask have become far from uncommon and that nowadays it is hard to recognize the man beneath the mask... ${ }^{3}$

Yet we see that the hero himself is undoubtedly a pretender, considering the first chapters of the novel, where Golyadkin aims at a better social position and is eager to create a better image of his personality. With the appearance of his double, Golyadkin exposes obedience and subordination, projecting all the immoral intentions on Golyadkin the Junior - his double.

Most of the research on the problem of the double in fiction tends to disclose the psychological links in the narrative, which is by all means justified but not complete without tracing the philosophical aspect of analysis and the investigation of the role of the double in structuring the narrative. Indeed, Dostoevsky, like Edgar Poe, penetrates deeply into the mind of the hero, as if showing the life 'from within'. What is undeniably relevant in terms of the psychological interpretation is the idea of the suppression of the subconscious by the conscious and the representation of one's other possible 'forms', 'selves' in the Double, when it 
appears that only through the 'other' the hero can fully understand his own personality.

However, such a conception of a split personality does not fully satisfy all the critics. For instance, Malcolm V. Jones argues that 'the 'selves' of the hero are well aware of each other's existence'. ${ }^{4}$ Jones stands for Lawrence Kohlberg's idea of the 'autoscopic syndrome' (a projection of the body image into space), pointing out that such authors as Hoffmann and Edgar Poe are thought to have experienced the syndrome, while Dostoevsky is known to have suffered from epilepsy.

The majority of Dostoevsky's biographers state that 'The Double' was Dostoevsky's favourite type of character, the problem that he was permanently developing. In one of his letters Dostoevsky even notices that 'The Double' was an important attempt to develop and express the most significant idea he had ever been interested in. It is necessary to notice that the novel 'The Double' was criticised for being 'too unreal' and some critics even claimed that the proper place for such fantastic things was the asylum for the mentally disabled. To a great extent such response was due to the novelty of the context in which the writer presents the figure of the Evil Twin: till the Romantic epoch the double motif in fiction used to be represented almost always in a comical way and it was in Romanticism when the idea of the double acquired already dramatic traits. Thus Dostoevsky's Petersburg Poem fell out of the literary canon of the time.

Golyadkin the Junior, the evil twin of the hero, a titular councillor Golyadkin, overpowers his 'original' in all circumstances, making the genuine Golyadkin's life intolerable. Because of his evil twin, Golyadkin loses the possibility of realizing his own value, his 'self', and witnesses the rapid ruin of his life. The city's suffocating atmosphere seems to drive the main character mad - we remember that the novel is called 'The Petersburg Poem' and the gloomy visions of the city obviously contribute a lot to Golyadkin's mental state.

The conventional views on the nature of the split in Golyadkin's mind either emphasize the hostility of the society (and the world in general) towards the hero (A. Latynina), or highlight the pressure of the Idea, which takes possession of him (A. Zlochevskaya). Thus the hero either feels the estrangement of the human existence, or is possessed by his own Idea of himself (or a Human in general), which does not coincide with his true image, leading to the dramatic dissonance. Depicting Dostoevsky's state during the arrest, the famous Russian existential philosopher Lev Shestov notices that the writer 'saw all of a sudden, that the penal walls, ideals and fetters were not in the least the opposite as he used to think, as he had considered as any ordinary man. Not the opposite, but the identical. There is no sky, but only a low, pressing horizon, there are no ideals - there are only the chains, invisible, but tying up more firmly than any prison fetters'.5 We see here, that the writer himself experienced the intolerable pressure of the world and the feeling estrangement and helplessness. 
The appearance of the double can be ascribed to the ontological human doubt of the loss of identity - this fear results in the real character of the double presented in the fiction and, finally, the pathological state of the characters' mentality is quite obvious to the reader. Irrespective of the views on the nature of the hero's discord, the idea of Golyadkin's 'quest for unity' remains unquestionable. Yet Golyadkin's tragedy is not merely a drama of the person with a mental split. In the tenth chapter Dostoevsky describes Golyadkin's nightmares, in one of which the hero runs out into the street to flee from shame and terror, but he fails, as there are copies, doubles around him, a horrible abyss of simulacra - thus we can say that the writer brings the problem of the double from the individual level onto the universal one.

An amazing fact is that doubling itself is so ambiguous in character, in its function in the narrative, since it reflects the character's submission to the destiny or higher powers, but, at the same time, though contradictory it may seem, it plays a crucial role of differentiation. Thus Doubling is characterised by both loss of identity and the attempts to regain it.

The famous Russian writer Merezhkovsky in his work 'Tolstoy and Dostoevsky' noticed that with time and the work of the critical mind the world changes - but the world is not becoming simple and all-evident. On the contrary, it has become much more frightening and mysterious. And Dostoevsky, as well as Edgar Poe, felt it acutely.

It is worth mentioning that Dostoevsky in his preface to the Russian edition of Poe's stories calls him 'an enormously talented writer', saying that Poe's works are marked by an incredible power of imagination that makes him so unique among other authors of his time. Dostoevsky notices that Poe invents the most extraordinary and even impossible situations, but due to the detailed way these incredible ideas are presented, the reader does not doubt their being veritable. Apart from this Dostoevsky admired Poe for his psychological insight and realistic grasp. We should say that these traits are characteristic of both of the authors.

Looking directly at the plot lines of Poe's 'William Wilson' and Dostoevsky's 'The Double', we can single out a certain 'reversed' similarity. Both of the main characters encounter their doubles and both of them are eager to get rid of the evil twins. Still while in Dostoevsky's novel Golyadkin is tortured by Golyadkin the Junior, the double in Poe's story, vice versa, manifests all the positive traits of the hero's personality. The narrator in 'William Wilson' admits the ultimate virtue of his double... his moral sense, at least, if not his general talents and worldly wisdom, was far keener than my own. ${ }^{6}$

And it is gradually becoming evident, that the hero is fighting with his own soul, still realizing that the double is originally close to him, ...it may seem strange that in spite of the continual anxiety occasioned me by the rivalry of Wilson, and his intolerable spirit of contradiction, I could not bring myself to hate him altogether... 
Likewise, Golyadkin, in Dostoevsky's novel, 'cherished no sort of hatred' towards his enemy. While William Wilson aspires to get rid of his 'evil' twin, Golyadkin makes every effort to get on good terms with Golyadkin the Junior, even realizing the uselessness of it - and this is what makes the characters different. Yet both of them realize vaguely that the doubles are not completely strange to them:

It was about the same period, if I remember aright, that, in an altercation of violence with him, in which he was more than usually thrown off his guard, and spoke and acted with an openness of demeanour rather foreign to his nature, I discovered, or fancied I discovered, in his accent, his air, and general appearance, a something which first startled, and then deeply interested me, by bringing to mind dim visions of my earliest infancy - wild, confused and thronging memories of a time when memory herself was yet unborn. ${ }^{8}$

We see that here, like in 'The Double', the hero can't help feeling the fine but inalienable connexion with his twin.

Another notable point of intersection in the stories is the character of the double's voice. In 'William Wilson' it is reduced to a mere whisper:

I could find, indeed, but one vulnerable point, and that, lying in a personal peculiarity, arising, perhaps, from constitutional disease, would have been spared by any antagonist less at his wit's end than myself - my rival had a weakness in the faucial or guttural organs, which precluded him from raising his voice at any time above a very low whisper. Of this defect I did not fail to take what poor advantage lay in my power. ${ }^{9}$

The same way, Golyadkin's double is mostly whispering 'in a hurried undertone', as if exposing his deceptive inferiority.

In both stories the narration reflects the internal speech of the heroes, and this speech is inevitably 'split' and illogical. As Mikhail Bakhtin notices in his 'Problems of Dostoevsky's Poetics', the hero 'cannot merge completely with himself in a unified monologic voice, his voice must also perform the function of surrogate for the other person. ${ }^{10}$ The 'organically incomplete' speech' serves here as a representation of the Other, and this strange speech tortures Golyadkin the Senior. Finally, both heroes are close in their striving effort to unmask their rivals: Golyadkin - in his feeble attempts to reveal his enemy's villainous essence, while William Wilson encounters his double before the tragic 'duel', hidden beneath a black mask. 
For Edgar Poe the doubling in general is linked to the phenomenon of Contradiction. Contradiction in the author's understanding is more than a mere painful trait of human mind, an obstacle for the normal way of living - it is a powerful device of conceptualisation of reality. It is a primeval impulse, elementary, archetypal, an innate principle of human behaviour. It is this ontological characteristic that Poe sets against the work of Reason - and this opposition grounds a split in the characters' minds. It is at the very essence of his characters' existence who balances on the edge of two worlds, two dimensions the real one and the unreal one (or the other world), the sphere of the influence of contradiction and imagination, and that of Reason. This contraposition shapes the narrative in 'Thou Art the Man', where the hero simply can not stick to common sense, 'The Oval Portrait' (where, by the way, we see the portrait as another representation of the double, alongside with the mirror and the shadow), in 'Morella' - it is the transition from one world to the other, in 'Eleonora' - the shift of one person into the other, a kind of transformation, in 'Berenice' - the counteraction between The Reason and an ill mind, monomania. These permanent oppositions are crucial for the understanding of the origin of the figure of the Double: they reveal the duality of the human existence in general, the constant transition from one world into the other, from one state into the other. It appears that Poe's characters simply cannot remain in some certain state or world - they would definitely overcome a certain limit, barrier, not infrequently death, and 'transcend' into another dimension.

Both 'The Double' and 'William Wilson' are not exclusively about the split of the characters' minds, though they end in the collapse of their mental state. Of great relevance here is also the disintegration of the hero's identity in the reality, which for him is inevitably 'slipping away', and the ruin of identity threats with the depreciation of everything around in general.

What is crucial about Poe and Dostoevsky's creation of the Double is that in this case there is no 'outward enemy' threatening the existence of the hero. No villain is really there to destroy the characters' life, but the enemy is too close, inalienable and therefore such case appears much more dramatic. The overcoming of the perception of the other as necessarily evil, the desire to separate oneself from the evil in one's soul, the unwillingness of admitting oneself capable of evil - these ideas stirred the great authors' imagination and make them so relevant nowadays. The certain 'nervousness', the extreme (not merely fantastic, but also spiritually extreme) situations the both writers place their heroes in, alongside with a most acute imagination combined with a keen sense of a detail - these aspects of Edgar Poe's and Dostoevsky's writing will always draw undiverted attention.

I would like to finish the chapter with the words of the famous Russian writer I. Annensky, who was wondering about Dostoevsky's 'The Double' - 'What is that? a nightmare? a phantasmagorical tale? No, it is something like the life, a true life! ${ }^{11}$ 


\section{Notes}

${ }^{1}$ P. Carus, The History of the Devil and The Idea of Evil from The Earliest Times to The Present Day, NuVision Publications, LLC, 2008, p. 7.

${ }^{2}$ L. Porter, The Devil as Double in the Nineteenth-Century Literature: Goethe, Dostoevsky and Flaubert, Comparative Literature Studies, Penn State University Press, 1978, p. 316.

${ }^{3}$ F. Dostoevsky, The Double: A Petersburg Poem, Courier Dover Publications, 1997, p. 61.

${ }^{4}$ M. Jones, Dostoevsky after Bakhtin: Reading in Dostoevsky's Fantastic Realism, Cambridge University Press, 2005, p. 40.

${ }^{5}$ L. Shestov, Collected Works, Vol. 2, Nauka, Moscow, 1993, p. 33.

${ }^{6}$ E. Poe, Collected Tales and Poems, Wordsworth Editions, 2004, p. 156.

${ }^{7}$ Ibid., p. 155 .

${ }^{8}$ Ibid., p. 155.

${ }^{9}$ Ibid., p. 154 .

${ }^{10}$ M. Bakhtin, Problems of Dostoevsky's Poetics, University of Minnesota Press, 1984, p. 235.

${ }^{11}$ I. Annensky, The Book of Reflections, Nauka, Moscow, 1979, p. 42.

\section{Bibliography}

Annensky, I., The Book of Reflections. Nauka, Moscow, 1979.

Carus, P., The History of the Devil and the Idea of Evil from the Earliest Times to the Present Day. NuVision Publications, LLC, 2008.

Dostoevsky, F., 'The Double': A Petersburg Poem. Courier Dover Publications, 1997.

Jones, M., Dostoevsky after Bakhtin: Reading in Dostoevsky's Fantastic Realism. Cambridge University Press, 2005.

Bakhtin, M., Problems of Dostoevsky's Poetics. University of Minnesota Press, 1984.

Poe, E. A., Collected Tales and Poems. Wordsworth Editions, 2004.

Porter, L. The Devil as Double in the Nineteenth-Century Literature: Goethe, Dostoevsky and Flaubert. Comparative Literature Studies, Penn State University Press, 1978. 
Ekaterina Yasko is a postgraduate student at Moscow City Pedagogical University (MCPU), Russia, currently studying the problem of evil in nineteenthcentury American literature. 


\title{
Steerpike and Evasive Villainy in Mervyn Peake's Gormenghast Novels
}

\author{
Arrate Hidalgo Sánchez
}

\begin{abstract}
Mervyn Peake's world of Gormenghast suffers from the misdeeds of a most enigmatic and attractive protagonist: Steerpike, the kitchen boy whose ambition raises him from the underground steams to the high roofs of manipulation and contagious madness. This chapter will explore Steerpike's relation to villainy as represented in Gormenghast's fictional framework. His function fluctuates between anti-heroism and villainy, as complicated by Titus Groan's own questionable position in the plot. The first novel, although named after Titus, clearly belongs to Steerpike, who appears at the moment of the eponymous 'hero's' birth. In a novel where the hero is an infant, Steerpike stands as the evil protagonist and Peake's real instrument of change. While an agent of change can be a villain, the question is in what manner Steerpike fulfils the novel's need for a hero until Titus is old enough for the role. Certainly, Titus's increasingly active performance in the second novel triggers Steerpike's gradual transformation into an identifiable villain. Steerpike's villainous trajectory is affected by fluctuations of power between the castle and Steerpike himself: his introduction as a young Machiavellian mind defines the castle in terms of decadence and powerlessness, a setting that will eventually reverse. Gormenghast not only gives the second novel its title, but also switches sides by depicting Steerpike as a menace in a seemingly eternal and unquestionable structure. Peake's ambiguous representation of the evil figure is in accordance with the overtly evasive nature of his fictional world. From the position of a fantasy character, Steerpike challenges classifications and escapes satisfactory definitions of the modern villain.
\end{abstract}

Key Words: Steerpike, fantasy, villainy, rebellion.

$* * * * *$

\section{Introduction}

Mervyn Peake's imagined castle of Gormenghast; unlimited, always growing, and always self-contained, fits within the frame of fantasy literature as what Colin Manlove would call an 'impossible world'.' Its impossibility, far from being defined by common criteria of magic or the supernatural, is rooted in its isolation from our reality. Gormenghast is, in both space and time, unattainable, restricted to its own thick walls and to the mountains surrounding them, and aware of no other land beyond its own. Yet, in addition to their spatio-temporal impossibility, that which definitively makes Peake's books qualify as fantasy is the deliberate strangeness of their characters. Psychologically unbelievable and socially 
awkward, the dwellers of the castle, including the servants and the ruling House of the Groans, are responsible for the colourful absurdity that is vital to the existence of the castle. Conversations never seem to lead anywhere, social relationships are dislocated, and love flourishes but very rarely.

While seemingly chaotic, his absurdity does not plunge Gormenghast into anarchy. The life of the castle is ruled by the Ritual, an overwhelming number of events and traditions (whose origin is already forgotten) which, in their daily performance and careful preservation, maintain the order of the castle and provide all its inhabitants with a meaning to their lives. In Edmund Little's words, 'Gormenghast is an end, a religion in itself', and not only the law, but also more abstract notions such as the distinction between good and evil are intrinsic to matters of loyalty to the Stones. ${ }^{2}$ It is as a rebel to the castle's status quo that we first learn about the ambitious Steerpike. He surfaces from the kitchens with an unknown past, an unnaturally sharp mind and, above all, a thirst for power that automatically turns him into practically the most (if not the only) dynamic character of the books. Lacking the most basic aspects of human goodness, yet young and resourceful, Steerpike defies categorisations in his fluctuations between the figures of antihero and villain. His evolution from complex protagonist in Titus Groan (1946) into a flat evil creature in Gormenghast (1950) suggests interesting interpretations of Mervyn Peake's views on villainy, fantasy, and his own work. ${ }^{3}$

\section{Steerpike as Antihero}

Steerpike's appearance in Gormenghast parallels the other vital change in the apparently static continuum of the castle: the new heir is born. Titus Groan, who inspires the title for the first novel and who turns one year old by its end, is but a passive agent of change and rather secondary character in the first book. With the prospect of Titus as hero still laying dormant, our attention is drawn to Steerpike, whose mobility, even if driven by an inhumanly evil mind, is the basis of the plot and triggers the narrative action. As Tzvetan Todorov pointed out in his classic study of fantasy, '[a] fixed law, an established rule [...] is what immobilizes narrative'. ${ }^{4}$ Steerpike, an uncanny specimen in a world where rebellion has never taken place, allows the novel to exist through an unheard-of objective: the gradual achievement of absolute power. The novel's detailed account of Steerpike's dealing with difficulties, especially physical ones (such as his almost impossible escape around the castle roofs), represents clearly the heroic function of overcoming obstacles as defined by in Vladimir Propp's in his analysis of the folktale. ${ }^{5}$ Even Peake, As G. Peter Winnington acknowledges, has seemed to feel a closer link to Steerpike than to Titus, as suggested by his use of the young man's name as a pseudonym in a letter, while no record is kept for Titus. ${ }^{6}$ The little heir's rather symbolic presence in Titus Groan would thus transfer his heroic features to the more eligible, if evil, young man. Steerpike, however, subverts those features 
and avoids falling too comfortably into an identifiable heroic pattern by, for instance, inspiring a marked repulsiveness.

After all, the reader is not driven to like him in any way, neither spiritual nor physical. His cold logic is unnatural, the product of a mind that is externalised in his 'malformed' appearance, a sum of limbs that individually look normal but together form an 'unexpectedly twisted total' ( $T G 127)$. Usually defined in terms of the abnormal or the inhuman, he has the barren quality of a mirror that can reproduce but not create. Unable to smile but only by devising 'a clever imitation' of one (TG 176), Steerpike absorbs and copies emotions, spontaneity, and art to the point of perfection, but all the while despising the imagination that fuels them. Surrounded as he is by the colourful and harmless madness of the castle, Steerpike's 'cold, calculating self, with his ordered mind like a bureau with tabulated shelves and pigeon-holes of reference' ( $T G$ 177) acquire very negative connotations. In many aspects, his behaviour fits almost perfectly with Zygmunt Bauman's definition of the duties of a bureaucrat:

What they must not do is allow themselves to be diverted from the straight path of sober, and uncompromisingly task-focused, rationality; not by compassion, pity, shame, conscience, sympathy or antipathy to the 'objects', nor by loyalties or commitments other than commitment to the task and loyalty to all the fellow bureaucrats committed as they are to its performance and to subordinates hoping to be sheltered from their responsibility for the consequences of their own committed labour. $^{7}$

Steerpike, 'nothing if not systematic' (TG 263), seems to be a condensed and distilled version of Bauman's bureaucrats, the only difference between them being that Steerpike has no companions - nor does he want them. He does have subordinates, though: Lady Cora and Lady Clarice, the Earl's sisters, brainless and semi-paralysed twins whose inert thirst for power makes them helplessly dependent on Steerpike. It is to them that Steerpike gives an illuminating short speech not exempt of cynicism: 'sometimes one has to do things, which are unpalatable. When great issues are involved one can't toy with the situation in silk gloves. No. We are making history and we must be stalwart'. (TG 258) The similarities between this speech and the rhetoric that Peake himself would expectably have heard during his years serving in the Second World War are too tempting to be ignored.

His is the kind of efficiency that post-war world would see in its crudest, cruellest form in the Nazi concentration camps. It would not be until after the first draft of Titus Groan was complete that Peake visited, as an official war artist, the concentration camp of Bergen-Belsen in 1945. The experience had, in 
Winnington's words, a 'devastating emotional impact' not only on him, but also on his family. Hannah Arendt's 1962 analysis of Adolf Eichmann, responsible for the administration of the death camps during the war, presents a portrait of the Nazi official to which Steerpike adapts with uncanny ease: 'nothing would have been farther from his mind than to determine with Richard III 'to prove a villain'. Except for an extraordinary diligence in looking out for his personal advancement, he had no motives at all'. ${ }^{8}$ With roughly two decades separating them, Peake's and Arendt's texts produce parallel agents of evil: namely, the force that originates from the combination of ambition and dehumanised (or dehumanising) bureaucracy. Yet Steerpike, committed to a task whose rationality does not need to be questioned, diverges in the second book from Arendt's Eichmann in a vital aspect. Arendt pointed out that Eichmann's 'diligence in itself was in no way criminal; he certainly would never have murdered his superior in order to inherit his post'. ${ }^{9}$ As we learn in Gormenghast, this is precisely what Steerpike will do. This event, as we will see below, marks the beginning of Steerpike's transformation and decline.

Through manipulation, hard work and murder, Steerpike, 'the soul of bland discretion' ( $G 341)$, is unstoppable for years in a castle where everyone is too busy being a caricature of themselves. The castle of Gormenghast, which has frequently been considered as a character of its own right (and even the most important, in Manlove's view), passively receives the blows of the only individual who does not adhere to the community that the Ritual maintains as united as powerless. ${ }^{10}$ And for all this grotesque stillness that is Gormeghast's very core, its inhabitants' ability to feel love for even the most unexpected things is, for us, more recognisable than Steerpike's cold blood. The increasingly complex motivations that Peake attributes to Steerpike in his personal war against authority do not make his mind more comprehensible. On the contrary, Manlove argues that Peake's insistence on attributing him certain combining characteristics, such as the youth's endless patience while being able to make quick decisions, are not reflected in the narration, causing that 'the reader loses touch with Steerpike and what drives him'. ${ }^{11}$ Instead, our eyes are turned to the, though awkward, more emotionally approachable characters that Steerpike is playing with.

\section{Steerpike as Villain}

Steerpike undergoes a critical transformation in Gormenghast. Eventually, he achieves a respectable and influential position as an apprentice to Barquentine, Master of Ritual. The metaphorical pigeonholes of his own brain materialise as he joins the performance of Gormenghast's tradition. In the BBC adaptation of the Gormenghast novels, the Ritual is kept and imparted from a grey and cold modernlooking office that, inserted in the Gothic surroundings of the castle, underlines a heartlessness that perhaps can only be found in our contemporary world. ${ }^{12}$ Along with Steerpike's achievement of a bureaucrat's position comes his new tendency to 
commit mistakes. These do not only lead to his death by the end of the book, but they also show his gradual mental disintegration. Steerpike's plan to kill Barquentine to gain the title for himself - something that, as I mentioned above, Hannah Arendt would have considered villainous - seems also fuelled by the youth's aesthetic concerns $\left(\begin{array}{ll}G & 158-9\end{array}\right)$. Even though Steerpike shows an appreciation for the quality of well-made objects, such a banal excuse for murder as Barquentine's ugliness only confirms that Steerpike's rational behaviour is not flawless. Steerpike kills his Master, but at a high price: Barquentine's love for Gormenghast gives him enough strength, once set on fire by Steerpike, to leap toward his murderer in a last attempt of 'righteous' revenge. Steerpike's fight to free himself from the old man's strong grip leaves him on the verge of death. Consequently, he acquires a fear of fire that will trigger numerous episodes of mental imbalance. Furthermore, the flames afford him the definitive sign of evil: his face will become disfigured, a mass of white and red clay, consumed by the fire. He becomes, in all aspects, a monster. This episode marks the beginning of the villainous Steerpike, 'meaner, more irritable, more impatient for the ultimate power which could only be his through the elimination of all rivals' ( $G 377$ ), and thus, more exposed to failure, which is another of the classic requirements for a villain. $^{13}$

Representing the durable quality of the castle, Gormenghast's most capable and balanced minds finally detect the root of evil that the whole castle had been suspecting lay underneath their years of disorder and mystery. Lady Groan and Doctor Prunesquallor gain power as Steerpike becomes a slippery public enemy who has lost all his charisma, and whose attacks are not any more a product of his initiative, but triggered by self-defence. The castle is elevated again to the category of character, as if it was 'recovering from an illness, or was about to have one' ( $G$ 333). The floods that turn the castle into an island force all the inhabitants to move higher up, a convenient situation in the search for Steerpike, whose human features become fainter the more cornered he feels. Interestingly, Peake's use of animals as metaphors for Steerpike - obviating his name, which is already quite descriptiveis enlightening, especially in this last section. He was already known as to have eyes that gave him a macaw look, and to be quick as a ferret, but in addition to this, his episodes of madness are centred in his crying like a cock $(G 374,492)$. Renamed as 'the Beast', Steerpike not only becomes animalised, but also is increasingly depicted in until then absent terms of Christian evil. 'Alone, loveless, vital, diabolic' ( $G$ 379), hidden under the 'pulpits' of the castle, he has 'slid into the skin of a solitary Satan' ( $G$ 437), eager to wear the crown, if not as ruler of Gormenghast, as its evil vanquisher.

Titus, already seventeen, and Earl by the time of Steerpike's chase, will perform (without realising it) the duties of a hero in response to the requirements of his castle and of the fictional frame itself: in a moment that has nothing of a battle climax, Titus will stab the heart of a Steerpike whose final cry of madness has 
prevented him from fighting back. The dichotomy that was impossible in Titus Groan takes a shape in Gormenghast that none of the characters seem able to confront. Titus has been constantly represented as a 'good rebel', a young man whose lack of interest in Gormenghast and in his duties as its lord would have implied an indifference towards Steerpike's deeds. Nonetheless, as Manlove argues, this is not the case. He points out that Peake has extreme difficulties in both finding a plausible reason for both Titus' rebel attitude and his murderous hate towards Steerpike, resorting to tedious explanations that more often than not are full of contradictions and imposed psychological drives. Similarly, while there is no apparent cause for Steerpike's hate for the castle, this unexplained core of hatred is more satisfactory than the specific reasons he artificially provides for murdering, seducing, and even wasting time in his attacks.

\section{Conclusion}

By transforming Steerpike into a mad villain overcome by Gormenghast's almost organic traditions, and by imbuing Titus with dubious yet effective heroic qualities, Peake approaches his second book with a structure that resembles a traditional fairy tale more than the incredibly rich fantasy world he depicted in Titus Groan. Hence, the second novel loses its most vital quality, that of being inexplicable, by being too insistently systematised. Steerpike, as a main character in the two novels, represents a whole fantasy universe that by accommodating to the exigencies of the genre, seems to lose interest and beauty. Manlove has gone as far as to suggest that the very existence of the second novel is already an effect of the author's adherence to one of the faults in common fantasy writing: 'he wanted, like many other writers of fantasy, to put overt 'sense' into his story, and to link it, didactically and otherwise, to the 'real' world without letting it speak for itself'. ${ }^{14}$ Ironically (and regrettably) enough, the unlimited, colourful and grotesque Gormenghast of Titus Groan seems closer to our reality. In Little's words, Gormenghast 'is nowhere and everywhere. It never existed but always has existed and is present now. Its essential features can be reproduced in any human institution: house, hospital, factory and university and church'. ${ }^{15}$ In it, the Steerpike that is still free of the bonds of traditional fantasy shines as a brand new kind of villain, whose evil roots lie hidden within the very foundations of our modern and rational society.

\section{Notes}

${ }^{1}$ C.N. Manlove, Modern Fantasy: Five Studies, Cambridge University Press, Cambridge, 1975, p. 3.

${ }^{2}$ E. Little, The Fantasts: Studies in J.R.R. Tolkien, Lewis Carroll, Mervyn Peake, Nikolay Gogol and Kenneth Grahame, Avebury, Amersham, 1984, p. 71. 
${ }^{3}$ References to the novels in the text will come between brackets, by page-number, in the body of the text: Titus Groan will be abbreviated as $T G$ and Gormenghast as G.

${ }^{4}$ T. Todorov, The Fantastic: A Structural Approach to a Literary Genre, Cornell University Press, Ithaca, 1975, p. 165.

${ }^{5}$ See V. Propp, Morphology of the Folktale, University of Texas Press, Austin and London, 1968, pp. 25-65.

${ }^{6}$ G.P. Winnington, Vast Alchemies: The Life and Work of Mervyn Peake, Peter Owen, 2000, p. 135.

${ }^{7}$ Z. Bauman, Liquid Fear, Polity, Cambridge, 2006, p. 62.

${ }^{8}$ H. Arendt, Eichmann and the Holocaust, Penguin, London, 2005, p. 114.

${ }^{9}$ Ibid., p. 114.

${ }^{10}$ C.N. Manlove, Modern Fantasy: Five Studies, Cambridge University Press, Cambridge, 1975, p. 217.

${ }^{11}$ C.N. Manlove, The Impulse of Fantasy Literature, Macmillan, London, 1983, p. 120.

${ }^{12}$ Gormenghast, dir. by A. Wilson, 4 episodes, BBC, 2000 [on DVD].

${ }^{13}$ See function XVIII in V. Propp, op. cit., p. 53.

${ }^{14}$ C.N. Manlove, The Impulse of Fantasy Literature, Macmillan, London, 1983, p. 126.

${ }^{15}$ E. Little, The Fantasts: Studies in J.R.R. Tolkien, Lewis Carroll, Mervyn Peake, Nikolay Gogol and Kenneth Grahame, Avebury, Amersham, 1984, p. 72.

\section{Bibliography}

Arendt, H., Eichmann and the Holocaust. Penguin, London, 2005.

Bauman, Z., Liquid Fear. Polity, Cambridge, 2006.

Gormenghast. dir. by Wilson, A., 4 episodes, BBC, 2000 [on DVD].

Little, E., The Fantasts: Studies in J.R.R. Tolkien, Lewis Carroll, Mervyn Peake, Nikolay Gogol and Kenneth Grahame. Avebury, Amersham, 1984.

Manlove, C.N., Modern Fantasy: Five Studies. Cambridge University Press, Cambridge, 1975.

—

Peake, M., Gormenghast. Vintage, London, 1998. 
—

Propp, V., Morphology of the Folktale. University of Texas Press, Austin and London, 1968.

Todorov, T., The Fantastic: A Structural Approach to a Literary Genre. Cornell University Press, Ithaca, 1975.

Winnington, G.P., Vast Alchemies: The Life and Work of Mervyn Peake. Peter Owen, 2000.

Arrate Hidalgo Sánchez is a postgraduate student of English Literature at the University of Leeds. Interested in the dynamics of evil and the supernatural in literature and popular culture, she is currently writing her dissertation on everyday life evil and its depictions in modern fantasy. 


\title{
Enter Peter Ackroyd's Nicholas Dyer: Architect, Devil Worshipper and Murderer
}

\author{
Roxanne Barbara Doerr
}

\begin{abstract}
Peter Ackroyd's anti-detective novel Hawksmoor gives life to an innovative and disquieting villain capable of stirring up sentiments of both profound disgust and undeniable fascination. Although Nicolas Dyer lived in the $17^{\text {th }}$ century he possesses characteristics pertaining to villains that are typical of preceding and following centuries. He therefore can be considered a 'pastiche' villain in that he combines worshipping of primeval and medieval demoniac practices, a typically Renaissance Machiavellian use of architectural and intellectual skills for his dark purposes and the criminal's apparent normality and elusiveness from the law that contemporary readers suspect and fear. His tragic past, fragile sanity and passionate devotion towards his mission, along with his cynical but clear-cut opinions on his time and its protagonists, often make him a sympathetic villain although he is admittedly guilty of many gruesome murders. Such insight into his life leads us to believe that there is a little villainy in each of us, making its presence a threat that is as invisible and everlasting as the hidden demoniac symbols located in the churches he charted. Dyer represents the darkness that perpetually lurks in the shadows of knowledge and enlightenment, and his mystic influence is such that centuries later his solitary but honest doppelgänger detective Hawksmoor is deeply bound to him through the reoccurring homicides that take place in the 1980s and perfectly mirror Dyer's. Moreover, as is often the case with postmodern detective novels, Dyer is never officially discovered or brought to justice, so anything even remotely resembling a realisation can only occur through an irrational solution, such as the epiphany that Hawksmoor experiences at the novel's closure.
\end{abstract}

Key Words: Peter Ackroyd, Hawksmoor, Nicholas Dyer, Pastiche villain, Postmodernism, Anti-detective fiction, Villainy and felony.

$* * * * *$

Peter Ackroyd's anti-detective novel Hawksmoor (1985), winner of the Whitbread Novel Award and the Guardian fiction prize, was partially inspired by Ian Sinclair's poem 'Lud Heat'. Here Sinclair suggests that the six churches charted and positioned by the architect Nicholas Hawksmoor in eighteenth-century London emanate a mysterious force through their structures. The historical Nicholas Hawksmoor is divided into two separate but gradually merging personalities in Ackroyd's novel: Nicholas Dyer, an extremely intelligent but cruel and cynical Satanist architect, and Nicholas Hawksmoor, a solitary detective who 
searches for a serial killer operating in the 1980s with the same modus operandi and victims that Dyer used.

This analysis will focus on Nicholas Dyer, an innovative and disquieting villain capable of stirring up sentiments of both profound disgust and undeniable fascination. His all too telling surname, as well as the time in which he lives, is significant as far as a discussion on the nature of evil and villainy is concerned. The $17^{\text {th }}$ and $18^{\text {th }}$ centuries were characterised by a widespread fascination in the sublime; this was reflected, among other instances, in critics' and readers' fascination with the 'heroic villain', ' whose wrongdoing was only comparable to his or her strength of mind and character. Dyer's childhood hero is Faustus (who sides with evil, in contrast to Sholom Kahn's idea of the supernatural and ancient concept of hero $)^{2}$ and his early memories are full of superstitions and gloomy nursery rhymes. He leaves his trace in official history as an eccentric architect whose work stands out for its 'ambivalent, exhilarating, and uncanny dimension. ${ }^{3}$ Those who have access to his thoughts and secrets however - his $20^{\text {th }}$ century alterego Hawksmoor and the reader - know that Dyer embedded his churches with satanic symbolism and the bodies of boys and vagrants in its foundations.

Nicholas Dyer lived in the $18^{\text {th }}$ century but possesses characteristics pertaining to archetypal villains of other centuries making him a postmodern 'pastiche' villain and an embodiment of the history of villainy. True to the stratified and monumental nature of Peter Ackroyd's plagiaristic creations, Nicholas Dyer is defined 'a little patchwork figure' by Ackroyd himself. His voice makes him 'constructed as much from Dr. Johnson's Dictionary in particular and numerous obscure eighteenth-century treatises on such subjects as gout and necromancy as he is from Ackroyd's inventiveness'. ${ }^{4}$ Such unification of different and diverging voices and personalities into one person results in a blurring and questioning of boundaries between what is evil and what is not that. This in turn confounds the debate on what makes a villain and how villainous a person can or must be.

This is most evident in the powerful and mutually influential identification between the two protagonists that leads us to trust or mistrust and therefore judge or condone them both. Brian Finney takes this consideration a step further and draws another comparison between the two Nicholases: 'At the level of ideas, Dyer and Hawksmoor begin as opposed to each other's belief in Satanism and rationality respectively and are drawn together by the end of the book'. Dyer however combines knowledge and mysticism and is learned both in the technicalities of his profession and in the history and manifestations of the dark arts he affiliates with.

Reaching far back into pre-Christian worshipping and medieval demoniac practices, Dyer not only rejects but perverts Christianity's fundamental doctrines in favour of an occult faith. The Satanist in fact, in Kahn's words '[appeals] to the spirited element, expressing a form of conscience, but conscience gone awry'. ${ }^{6}$ This is especially important because at the time spiritual valor was considered more important than physical strength. Dyer therefore understands the Church's 
teachings and has a working conscience, but has simply decided to devote himself to the Devil's cause because God's workings have never given him reason to believe or want to believe.

Such reverence for evil is coupled with a typically Machiavellian use of extensive architectural studies and intellectual skills to accomplish his dark purposes. Since the advent of the Renaissance and Humanism in fact the battle between good and evil is no longer clear-cut and its more allegorical representations are confined to folklore and imagination. The emphasis is now on the individual's talents and his or her interior struggle between virtue and vice. ${ }^{7}$ Due to his cleverness and dutiful work Dyer deservedly occupies his prestigious position as assistant surveyor of the post Great Fire churches and supervises over their construction. He defiles the belief voiced by Saint Thomas that 'the evil that a wise artist introduces into his work in order to avoid another evil is a lesser evil than the one he is trying to avoid ${ }^{8}$ because he purposely introduces evil into his work in order to perpetrate even more evil. His plan seeks to deviate humanity by targeting children or child-like adults whose bodies are incorporated into the very foundations (and roots) of churches, which also contain icons or images that recall satanic symbolism. This way Dyer hopes to contaminate important Christian locations spread out throughout London. He is therefore also a villain in that he seeks to promote 'the greatest balance of evil over good for the greatest amount of people'. ${ }^{9}$ By being a cunning and 'trustworthy' agent of darkness Dyer proves therefore to be more dangerous than any completely devoted but imprudent fanatic.

Despite this, the reader is never hostile towards Nicholas Dyer. For one thing, he is always candid about his devious nature and the despicable plans on which he focuses his undivided attention. He is also open about his tragic past, which saw him overcome numerous hardships such as the Plague, the Great Fire of London, and subsequent life on the streets. Dyer however never uses these misfortunes as an excuse, nor does he seek the reader's pity. His discovery by the mystic Mirabilis as a 'Chosen One' with 'the Hand' upon him, and his initiation into the miracle man's circle after being isolated in a dark sacred chamber follow the traditional rituals of many occult societies. ${ }^{10}$ The Black Step Lane community gives Dyer the purpose of life that he was lacking and the opportunity to hone his potential. During their last brief encounter Mirabilis gives Dyer his last orders: 'You will build [...] and turn this Paper-work house (by which he meant the Meeting-place) into a Monument: let Stone be your God and you will find God in the Stone'. (p. 51). ${ }^{11}$

After having been a scapegoat Dyer is now in a position of power and uses it to turn his victims into scapegoats, although without granting them the chance to prove themselves worthy of living that he was granted. He is not however totally unfeeling towards his victims, for he identifies with them. He often considers himself a child or a vagrant despite his worldly accomplishments and gives the lowly great importance that society denies them. ${ }^{12}$ In seeing a group of vagabonds for instance he calls them 'a Society in Miniature' and claims them for himself. ${ }^{13}$ 
Such attribution of importance to social categories that are generally considered marginal is an attitude that well suits both postmodern thought and Dyer's persistent resistance to the mainstream Enlightenment society and highbrow intellectualism. Instead he favours the 'others' who, like Dyer, 'fulfill a critical social function in defining conventional morality and behavior by providing a $n e$ plus ultra, against which normal society readily finds common ground' (original italics). ${ }^{14}$ Nicholas Dyer also has a peculiar relationship with the insane and is himself prone to bouts of insanity, which become more frequent and intense as he proceeds with his task. ${ }^{15}$ The belief that the insane have a sort of unexplainable insight is also relevant here. The first character in the novel to reveal Dyer's doings and detective Hawksmoor's future involvement is a madman in Bedlam not coincidentally known as the 'Demoniack'. At one point he directly addresses Dyer: 'What more Death still Nick, Nick, Nick you are my own! [...] Hark ye, you boy! I'll tell you somewhat, one Hawksmoor will this day terribly shake you!' (p. 100) Considering that 'Old Nick' is also another name for the Devil, it seems as if the dark forces Dyer had been employing were coming back to haunt him though similarly irrational means.

Dyer does not feel at ease with his time; on the contrary he is totally at odds with the 'enlightened' society of London. He reacts to this oppression through what Alex Link calls an 'opposition to monumentalization' ${ }^{16}$ and the revendication of 'local knowledge and local resistances'. ${ }^{17}$ This sentiment fuels his search to comprehend mysteries that go far beyond the scientific laboratory and his desire for the past and the 'outside' to remerge. ${ }^{18}$ His is a subtle sort of subversion through cynical but clear-cut and witty opinions on the time and its protagonists, including his prestigious employer Sir Christopher Wren. Accordingly, his contaminated churches become subtle 'instruments of systematic disorder'. ${ }^{19}$ Because of this anachronistic and anticipatory ability to question and criticise the 'obvious', Dyer stands out although his theories are often disregarded because they are based on 'unreliable sources', as David Richter has also observed. ${ }^{20}$

Nevertheless, although at one point suspicion for the killings is cast upon him, his satanic affiliations are never openly discovered nor revealed. Dyer's presence is ever the more imposing because of Hawksmoor's late appearance in the novel and his apparent incapability to follow 'the Architect's' pace (which is that with which the reader proceeds through Dyer's personal narration). Interestingly, Philip Jenkins observes that in the 1980s (the decade in which Hawksmoor was written and the murders of detective Hawksmoor's story took place) there was a noticeable rise in the amount of mass and serial murders taking place and consequently of their coverage by the media. ${ }^{21}$ These crimes were considered acts of the utmost villainy, especially when children were involved. Dyer's return therefore almost seems to have surpassed the boundaries of fiction and found its renewal in the real world. 
Nicholas Dyer never repents, nor does he seek redemption. On the contrary, he is proud of his mission and desires only to be able to finish it before 'his time' is up. It is this capability of his to always 'get away with it' that makes Dyer most terrifying as a villain. Not only does Dyer escape justice during his lifetime but he haunts his $20^{\text {th }}$ century counterpart with a series of killings is just as cruel and elusive. The only instance in which he fears (human, not divine) punishment is when he is being blackmailed by someone who knows of his doings. Even then though, he only limits himself to softly saying 'Oh no, my Sentence is just' (p. 103) before reassuring himself that: 'I know my own Strength [...] for it has been tried and, if I foresee Storms, it is fit that I should prevent them' (p. 104). Upon finally completing his work he mockingly claims: 'I have built an everlasting Order, which I may run through laughing: no one can catch me now' (p. 186). In the end, as opposed to what we are accustomed to, the villain has won the race against time and society.

One reason why Dyer remains unpunished could be teased out by Leo Katz's helpful distinction between villainy and felony. Katz points out that many deplorable actions accomplished by both fictional and real people may be perceived as villainous and morally condemnable, but it does not necessarily follow that they are criminal felons (and therefore punishable by law) ${ }^{22}$ In this case we could add perpetration of evil and enablement of murder and violent death. In fact, although Dyer is obsessed by his mission and finding new sacrifices he, as Alex Link acutely points out, never kills any children or vagrants himself. ${ }^{23} \mathrm{He}$ urges the first victim to continue climbing insecure scaffolding, encourages the second victim to commit suicide, and has a fellow Satanist kill the third. It is only towards the end of the novel that he personally kills his rival Hayes, whom he ironically always refers to as 'the villain'. This marks the beginning of Dyer's downfall as if it were the retribution he had long deserved but could only receive after committing a real 'felony'. Nevertheless, Dyer still manages to escape conviction by driving his blackmailer to suicide and reaching his last (and nonexistent) church. $^{24}$

At this point, Dyer experiences an epiphany that is once again the reversal of its traditional religious notion. Instead of an exhortation to convert to goodness or a realisation of the error of his ways as would be supposed, his kneeling in front of the light shows his final triumph as the villain and dark architect who casts a menacing shadow over unknowing humanity. Our insight into Dyer's thoughts and our admiration, if not sympathy, for his plight and endeavour gives us the feeling that there is a bit of Dyer in each of us. This sensation further enhances his 'presence' and the threat of subversion that undercover villains like Dyer represent.

In conclusion, just as postmodernity questions fundamental concepts such as truth, history, identity and certainty, the fate of a villain such as Nicholas Dyer questions the feasibility of justice for, as Costas Douzinas sustains, "postmodernity has undermined our belief in the universality of law or in the ability of an ideal 
equity to ground its operations. ${ }^{25}$ This in turn makes us doubt the hitherto consolidated obviousness of the ideal outcome of the struggle between good and evil, making this 'patchwork-pastiche villain' all the more powerful and threatening but at the same time captivating and memorable.

\section{Notes}

${ }^{1}$ S. Kahn, 'The Problem of Evil in Literature', The Journal of Aesthetics and Art Criticism, Vol. 12, No. 1, Special Issue on Symbolism and Creative Imagination, September 1953, pp. $37 \&$ 98-110.

${ }^{2}$ Ibid., p. 107.

${ }^{3}$ E.J. Ahearn, 'The Modern English Visionary: Peter Ackroyd's Hawksmoor and Angela Carter's The Passion of New Eve', Twentieth Century Literature, Vol. 46, No. 4, Literature and Apocalypse, Winter 2000, pp. 453-469.

4 B. Finney, 'Peter Ackroyd, Postmodernist Play and Chatterton', Twentieth Century Literature, Vol. 38, No. 2, Summer 1992, pp. 240-261.

${ }^{5}$ Ibid., p. 247.

${ }^{6}$ S. Kahn, op. cit., p. 105 (footnote).

${ }^{7}$ Ibid., p. 108: '[...] since the Renaissance, the bounds of good and evil have been much less clearly marked, chiefly because we moderns have lost the strong rock of a supernatural sanction and the clear guide of a revealed Scripture'.

${ }_{9}^{8}$ C Connellan, op. cit., p. 79.

9 J.M. Trau, The Co-Existence of God and Evil, Peter Lang, New York, San Francisco, 1991, p. 69.

${ }^{10}$ R. Stivers, Evil in Modern Myth and Ritual, The University of Georgia Press, Athens, Georgia, 1982, p. 119: 'In many societies mass transgression of sacred taboos are preceded or followed by ritualistic scapegoating, which involves the transfer of evil onto some other thing, animal, or person, who bears the collective evil of the community. [...] Originally the victim was regarded as divine, which would explain his power to expiate sins. [...] today the victim often becomes the precise opposite of divine.'

${ }^{11}$ All quotations and references to the text will be taken from the following edition: P. Ackroyd, Hawksmoor, Penguin Books, London, 1993 and page numbers will be indicated parenthetically. All italics and orthographical peculiarities are from the original text.

12 S. Fiorato, Il Gioco con l'Ombra, Edizioni Fiorini, Verona, 2003, p. 78: 'In Ackroyd's narrative attention towards madmen or vagabonds is recurrent, for they are symbolized as the closest to the truth because of their social isolation, which also coincides with cultural isolation, for they don't share reality's interpretative schemes' (my translation); 'Nella narrativa ackroydiana, ricorrente è l'attenzione per i pazzi o vagabondi che si configurano come i più vicini alla verità, proprio in virtù della loro emarginazione sociale, la quale coincide anche con una 
emarginazione culturale, poiché essi non condividono gli schemi interpretativi della realtà.'

13 ' $[. .$.$] their place is by my Church: they are the Pattern of Humane life, for others$ are but one Step away from their Condition, and they acknowledge that the beginning and end of all Flesh is but Torment and Shaddowe. They are in the Pitte also, where they see the true Face of God which is like unto their own', p. 63.

${ }^{14}$ P. Jenkins, Using Murder: The Social Construction of Serial Homicide, Aldine de Gruyter, New York, 1994, p. 112.

${ }^{15}$ D. Carpi, In Limine: Cultura ed Enigma, Alinea Editrice, Florence, 1997, p. 96: 'the events' progression marks the character's regression towards an illogical, pathological state, i.e. folly' (my translation); 'Il progredire degli eventi segna il regredire del personaggio verso uno stato a-logico, patologico, cioè verso la follia.'

${ }^{16}$ A. Link, op. cit., p. 519.

${ }^{17}$ Ibid., p. 520.

18 'This mundis tenebrosus, this shaddowy world of Mankind, is sunk into Night; there is not a Field without its Spirits, nor a City without its Daemons, and the Lunaticks speak Prophesies while the Wise men fall into the Pitte. We are all in the Dark, one with another. And, as the Inke stains the Paper on which it is spilt and slowly spreads to Blot out the Characters, so the Contagion of darkness and malefaction grows apace until all becomes unrecognizable', p. 101.

${ }^{19}$ Ibid., p. 520.

${ }^{20}$ D. Richter, 'Murder in Jest: Serial Killing in the Post-Modern Detective Story', Journal of Narrative Technique, Vol. 19, No. 1, 1989, pp. 106-115: '[...] when Dyer is not murdering innocents to lay their corpses in the foundations of his Satanic churches, he is engaging in a running debate, a querelle des anciens et des modernes - against a series of rationalistic opponents, who include fictional characters along with real ones like John Vanbrugh and Christopher Wren.'

${ }^{21}$ P. Jenkins, op. cit., p. 81: '[...] steady shift away from the portrayal of multiple killers as creatures of individual psychopathology ('psychos'), and toward more moralistic and even supernatural interpretations of ever more terrifying and dehumanized monsters. This transition occurred in both cinema and the novel, and it profoundly influenced media coverage of the topic.'

${ }^{22}$ L. Katz, 'Villainy and Felony: A Problem Concerning Criminalisation', Buffalo Law Review, Vol. 6, No. 451, 2002, pp. 451-482: '[...] most of the things we get outraged by in our daily lives have to do with non-felonious villainy. [...] Interestingly, often these stories of non-felonious villainy derive their fascination from our instinctive befuddlement that such villainy should remain beyond the reach of the law.'

${ }^{23}$ A. Link, op. cit., p. 530.

24 '[Then] I opened the Door and crossed the Threshold. I walked forward saying, From my first Years Thy Horrours have I endured with a troubled Mind, and I 
stood in the Aisle looking upwards till I could look no more: I had run to the end of my Time and I was at Peace. I knelt down in front of the Light, and my Shaddowe stretched over the World', p. 209.

${ }^{25}$ C. Douzinas, 'Law and Justice in Postmodernity', The Cambridge Companion to Postmodernism, S. Connor (ed), Cambridge University Press, Cambridge, 2004, p. 197.

\section{Bibliography}

Ackroyd, P., Hawksmoor. Penguin Books, London, 1993.

Ahearn, E. J., 'The Modern English Visionary: Peter Ackroyd's Hawksmoor and Angela Carter's The Passion of New Eve'. Twentieth Century Literature. Vol. 46, No. 4, Literature and Apocalypse, Winter 2000, pp. 453-469.

Carpi, D., In Limine: Cultura ed Enigma. Alinea Editrice, Florence, 1997.

Connellan, C., Why Does Evil Exist? A Philosophical Study of the Contemporary Presentation of the Question. Exposition Press, Hicksville, New York, 1974.

Connor, S., The Cambridge Companion to Postmodernism. Cambridge University Press, Cambridge, 2004.

Fiorato, S., Il Gioco con l'Ombra: Ambiguità e Metanarrazioni nella Scrittura di Peter Ackroyd. Edizioni Fiorini, Verona, 2003.

Danzinger, M.K. 'Heroic Villains in Eighteenth-Century Criticism'. Comparative Literature. Vol. 11, No. 1, Winter 1959, pp. 35-46.

Finney, B., 'Peter Ackroyd, Postmodernist Play and Chatterton'. Twentieth Century Literature. Vol. 38, No. 2, Summer 1992, pp. 240-261.

Haybron, D., 'Evil Characters'. American Philosophical Quarterly. Vol. 36, No. 2, April 1999, pp. 131-148.

Jenkins, P., Using Murder: The Social Construction of Serial Homicide. Aldine de Gruyter, New York, 1994.

Kahn, S., 'The Problem of Evil in Literature'. The Journal of Aesthetics and Art Criticism. Vol. 12, No. 1, Special Issue on Symbolism and Creative Imagination. September 1953, pp. 98-110. 
Katz, L., 'Villainy and Felony: A Problem Concerning Criminalisation'. Buffalo Law Review. Vol. 6, No. 451, 2002, pp. 451- 482.

Kent, B., 'Evil in Later Medieval Philosophy'. Journal of the History of Philosophy. Vol. XLV, No. 2, April 2007, pp. 177-205.

Link, A., 'The Capitol of Darknesse': Gothic Spatialities in the London of Peter Ackroyd's Hawksmoor'. Contemporary Literature. Vol. 45, No. 3, Autumn 2004, pp. 516-537.

Needleman, B. \& Weiner, N.L., 'Heroes and Villains in Art'. Society. Vol. 4, No. 1, pp. 35-39.

Ohlsson, R., The Moral Import of Evil: On Counterbalancing Death, Suffering, and Degradation. Filosofiska instituitionen, Stockholm, 1979.

Onega, S. \& Ackroyd, P., 'Interview with Peter Ackroyd'. Twentieth Century Literature. Vol. 42, No. 2, Summer 1996, pp. 208-220.

Peterson, M.L., 'Recent Work on the Problem of Evil'. American Philosophical Quarterly. Vol. 20, No. 4, October 1983, pp. 321-339.

Richter, D., 'Murder in Jest: Serial Killing in the Post-Modern Detective Story'. Journal of Narrative Technique. Vol. 19, No. 1, 1989, pp. 106-115.

Stivers, R., Evil in Modern Myth and Ritual. The University of Georgia Press, Athens, Georgia, 1982.

Trau, J.M., The Co-Existence of God and Evil. Peter Lang, New York, San Francisco, 1991.

Roxanne Barbara Doerr is a doctorate $(\mathrm{PhD})$ student of English studies at the department of English Studies at the University of Verona and winner of an international scholarship for a partnership doctoral project with the University of Cologne. Her research areas are: law and literature, law and equity, law and culture, postmodern literature, literature and visual arts. 



\section{PART III}

Literary Villainy with an Ethnic Twist 



\title{
Washington's Troops Skinned Dead Indians from the Waist Down and Made Leggings from the Skins: Reiterating Villainy in Native American Gothic Fiction
}

\author{
Corinna Lenhardt
}

\begin{abstract}
Gothic fiction lives and breathes villainy. Without its murderous villains, there would be no Gothic fiction. And from the start, this villainy has been depicted in terms of monstrous savagery. In 1764, Horace Walpole, the presumed founding father of the Gothic literary genre, introduced the soon to be prototypic 'savage, inhuman monster' in England and triggered an onslaught of savage villainy throughout Europe. Riding the high tide of literary fashion, the Gothic Savage Villain even travelled across the ocean and to the shores of the New World, where the maze of natural wilderness and human struggle soon proved to be his perfect environment. In early American Gothic fiction, the prototypic Savage Villain became blended with the terrors of the all-enclosing wilderness, and with the contemporaneous personification of horrific wildness: the Native American savage. Gothic villains were no longer characterized by behaving savagely, but were morphed into full-fledged, snarling and roaring savages. However, the Gothic villain cannot be dismissed as being one instance of a racially overdrawn 'othering' of presumed dangerously deviant minorities. Indeed, while the savage villain set out to captivate mainstream American literature, those minorities depicted as savages set out themselves to renegotiate and rewrite the racialised villain by employing Gothic writing strategies. Today, savagery remains the key characteristic of the (American) Gothic villain. The chapter pinpoints different strategies of renegotiation employed to rewrite villainy in contemporary Native American Gothic fiction. As cases in point, Michael Baggett's Soapstone and Aaron A. Carr's Eye Killers will be analysed in depth. Drawing on historical sources and on the most recent developments, the underlying, discourse-altering effects of this truly revolutionary literary form are analysed and contextualised from a postcolonial perspective. However, the chapter refrains from classifying Native American Gothic fiction as postcolonial literature. The one thing the presence of all American Gothic villains makes hauntingly clear is that colonialism still exists in the Americas today.
\end{abstract}

Key Words: Villainy, Gothic literature, savagery, Native American fiction, post/colonialism. 


\section{Gothic Fiction and Its Villains}

Gothic fiction lives and breathes villainy. Haunted castles, stifling labyrinths, alleys and cellars, trap doors and hidden passages, darkness that is only seldom and sparsely illuminated by dim moonlight, the disfigured but humble servant, the pursued fair maiden and her languid but just as fair saviour in the hour of need these are all conventional and therefore very familiar settings, props, and characters of the Gothic; however, as soon as Prince Manfred of Otranto, Padre Ambrosio, Dr. Frankenstein or Count Dracula himself enter the stage, everything and everyone else back off and melt into the backdrop against which the enigmatic and charismatic villain can act out his evil and lascivious nature to the fullest. It is the villain who is the centre of all narrative attention, plot and character development; it is the lurking villain of whom we cannot rid ourselves long after we have finished reading the book or watching the movie; and, last but not least, it is the villain who has turned the Gothic into an unparalleled and ongoing bestselling success.

Over the centuries, invaded genres, ${ }^{1}$ cultures, and countries, the Gothic villain has undergone profound changes. No longer the monstrous epitome of the evils of aristocracy, Catholicism, permissiveness, and industrialization, contemporary Gothic villains like Stephen King's Cujo, Thomas Harris' Hannibal Lecter or Stephenie Meyer's Edward Cullen/Jacob Black arguably have undergone a 'journey [...] from monster to yuppie'. ${ }^{2}$ Whether yuppie or monster, the one core quality all villains share is their functioning as a negative foil for the construction of our humanity, for the guidelines against which we define normality and healthiness.

The occupation with what is villainously 'other', suppressed and unvoiced in a particular culture has granted the Gothic the status of being a radically subversive 'literature of revolution', as Edmundson claims. ${ }^{3}$ To create the Gothicised 'other', representing a culture's discursively repressed, dark underside, authors from eighteenth-century England onward have relied on the stereotypical otherness they encountered in daily life: the dark-skinned, black-haired Mediterranean, who would eventually be morphed into the all-black savage creature of the colonies.

His Nose was aquiline, his eyes large black and sparkling, and his dark brows almost joined together. His complexion was of a deep but clear Brown; Study and watching had entirely deprived his cheek of colour. ${ }^{4}$

Even a vampire's dead-pale complexion can be morphed into being 'dark [with] great dark, piercing eyes, that seemed to be almost red [...] ${ }^{5}$ or can at least be counterbalanced by his being 'clad in black from head to foot'.

From the depiction of villainously darkened brows, reddened skin, and piercing black eyes it is only a small step to the full-blown roaring and snarling Savage 
Villain. Ironically, by voicing the unvoiced through the distorted lens of the Gothic villain, the Gothic itself has created a racially distorted and silencing master discourse.

\section{Savage Villains and Villainous Savages}

The traditional English Gothic villain is depicted in colonialist imagery with very visual racist underpinnings. ${ }^{7}$ When finally reaching the peak of violence and confusion, the moment the villain loses his morality and fear of God, there is a slight but significant change of vocabulary used to portray him. As the outraged, loathsome man betrays his humanness his features become increasingly racialised, darker, until he resembles a 'savage, inhumane monster'.

Early American writers (most famously Charles Brockden Brown in the first full-fledged American Gothic novel of 1799, Edgar Huntley; or Memoirs of a Sleep-Walker) imported the best-selling Gothic from England and they took up the motif of savagery to depict the loss of civilized and pious human qualities within the Gothic villain. What they added is the real savage. Instead of acting and looking like a savage in his immorality and blasphemy, the villain is blended with the personification of all immorality and blasphemy: the Evil Native American Savage.

The motif of the Evil Savage, of course, is no invention of the English and/or American literary tradition, let alone of Gothic fiction. However, for the American Gothic the Evil Savage motif offers the perfect outlines for a villain: Wild and vicious, predatory, and cowardly lurking among bushes, he needs to be overcome for the sake of God's divine plan and for one's own survival. And if a 'not-quitehuman' creature of darkness is established as the adversary, the hero's quest will not be plagued and slowed down by ethical questions and restrains. ${ }^{9}$

\section{Reiterating Gothic Villainy, or When the Villain Grabs a Pen...}

Colonial Gothic texts, as I have argued above, depict 'the colonized subject as the terrible and fearsome 'other' who symbolizes the literally dark self of the colonizer and assures him of his own moral integrity and identity. ${ }^{10}$ While the racialised villainous savage still haunts the Gothic today, it is essentially a radically open and adaptable writing strategy. The Gothic employs a fixed canon of conventional dichotomies (e.g. villain-hero/heroine) in order to reiterate a dominant discourse of otherness from the perspective of those who are denigrated as being other. The Gothic, therefore, can produce highly politically charged, even revolutionary texts, which not only envision a counter-narrative to the dominant racialised discourse but aim at changing this discourse all together. The Gothic trades and quotes stereotypes but it has the potential to quote with a twist. This twist can either describe the new context/genre etc. in which the conventions are employed or it can describe the discourse-altering reiteration the author undertakes. In other words, while some Gothic texts repeat old racialised stereotypes in new 
contexts and therefore strengthen the underlying discriminating discourse, other Gothic texts write back critically in order to make visible and change the hateful discourse.

While this writing strategy becomes visible only from today's perspective of postcolonial studies, it is not limited to postcolonial times or places. From the earliest days of American literary production onward, both literate Native Americans like Samson Occom and William Apess and former African and African-American slaves like Frederick Douglass and Hannah Crafts have not only claimed and rewritten WASP literary genres; they have also used Gothic conventions as key strategies to critically and actively engage in the reiteration of the violent master discourse of oppression and slavery. ${ }^{11}$ Today, some would argue that in a time of ongoing colonialism in the Americas, a diverse, often culturally relative, and highly hybrid American Gothic has emerged from the continuous quotation and reiteration of conventional Gothic features. Conscious of the limits of this chapter, I can only hint at the vast diversity and complexity of the Gothic villain in contemporary American fiction by pinpointing two opposing reiteration strategies in recent Native American fiction.

In his openly politically incorrect novel, Soapstone (2004), ${ }^{12}$ Southern Cherokee Nation citizen Michael Baggett starts off with a truly Gothic climax: the villain has been overcome and is now expelled from the scenery. The brutal oppressor of the past, who 'has caused nothing but chaos, pain, and ruin' offers '[a]s consolation for [his] many sins, and as an admission of [his] guilt' his demise $(S$ 7). Immediately the harmony-seeking ending of the traditional Gothic novel comes to mind, in which the hero has not only won his battle but the defeated villain repents his sins. Baggett uses a significant twist, however. The evil aggressor, the 'Great Satan' $(S 2)$ of the novel is no other than the United States of America, represented by the 'former world leader' himself, the US president $(S 8)$. In the wake of $9 / 11$ and an escalated US War on Terror, the world's nations have allied with the terrorists to form the 'Nations Against American Aggression' $(S 5)$. The NAAA's resolution is fantastically simple:

America must be erased. The clock would effectively be turned back to 1492 and all descendants of immigrants must return to their homelands. (S 7)

And so it happens. The US as the epitome of civilization and colonization is first transformed into an omnipresent ghost town $(S 94)$, and, in a second step, to a pre-contact state of wilderness. Baggett's reiteration strategy essentially turns the Gothic upside down. The presumed civil and rational white colonizer is depicted as the father of a violent and racist discourse and eventually Gothicised and othered himself until he is the one morphed into the full-fledged predatory and cannibalistic savage: 
George Washington's troops skinned dead Indians from the waist down and made leggings from the skins. Washington hated Indians, said we were nothing more than beasts of prey, like wolves. And he was the father of the country. (S 101)

Counterbalancing the white Savage Villain, the Native American protagonist assumes the role of the questing hero. The alienated Cherokee Ryan Becker has to overcome the 'barbaric' colonial reality by transgressing both the gruesome past, when soldiers killed defenceless elders and children ('They killed her sister, cut her heart out, and threw it into a bush. This little child hid under the bush until the soldiers left, holding her sister's heart in her hands.' $S$ 102), and the present day's after-effects of violence, oppression, and centuries of internalising the racist master discourse (as embodied by the group of scalping, robbing, and raping 'REDMAN' [sic] who aptly lurk among the ruins of white civilization). In Baggett's radical inversion of Gothic imagery, the formerly haunted American Gothic wilderness becomes the safe haven of 'the old, healthful ways' $(S 78)$, an idealistically overdrawn one-with-nature Indian identity to remember and to embrace freely and nakedly (cf. $S$ 119). Baggett at the same time quotes and twists the Gothic's melodramatic separation of characters into heroes and villains - the racial discourse underlying all acts of othering, however, remains untouched at best and strengthened at worst.

The need to remember and voice the Indian way is also at the core of Aaron Albert Carr's vampire novel, Eye Killers (1995). ${ }^{13}$ The Navajo and Laguna Pueblo author and filmmaker created a story that carefully blends the Gothic vampire plot with Navajo/Laguna myth. On one level, Carr constructs a patchwork family of vampires as a 'combination of European aristocracy and nineteenth-century American settlers, pushing destructively west'. ${ }^{14}$ Falke, Carr's chief 'Eye Killer', is a former Austrian monarch, more than nine centuries old, a shape-shifting and mind-controlling vampire with a German name, snow-white skin, blond hair, and ocean-blue eyes with dilating black pupils. His two mistresses, Hannah and the still half-human Elizabeth, are both American settlers, daughters of 'stolid frontier wom[e]n' ( $E K$ 39). Judging from Carr's blending of the blood-sucking European vampire villain with the destructive forces of colonization, it is fair to assume a Baggett-style repetition of the colonizers' discursive violence by inversely reinscribing villainy and otherness. However, there is a deeper level to Carr's reiteration of Gothic villainy.

Carr's vampires are not just vampires; they shimmer between the European vampire with colonial American underpinnings and the mythological Eye Killers which are part of the Navajo creation story. Eye Killers, Carr points out, are almost 'holy beings', they reign 'above us, so they are both good and evil' while still showing 'totally human' characteristics. ${ }^{15}$ Falke, in other words, becomes the Gothic epitome of cultural hybridity. As a matter of fact, the classic vampire hunter 
will not do when Falke chooses to lure his new bride, the troubled Albuquerque teenager Melissa Roanhorse. To regain Melissa from the claws and fangs of Falke, her Irish-American English teacher Diana ${ }^{16}$ and Melissa's Navajo grandfather Michael must unite, share and connect the culturally relative bits and pieces that together form the hybrid villain, and jointly battle Falke. Diana, in full war paint and armed with the 'savage's magic' (EK 317f.), with Navajo rituals and artefacts, combines her own Western cultural knowledge of vampire tales with Native American myth and drives a wooden prayer stick like a stake through Falke's heart; Melissa, in fear for her grandfather, drives a second prayer stick into Falke's heart and defencelessly Falke is burnt to ashes by the rising sun; finally, Michael scatters Falke's ashes in the currents of a sacred Navajo river - and only then is the villain killed for good.

Carr, in sharp contrast to Baggett, reiterates the Gothic to a point where all types of racialised separations between good and evil, fair and dark, civil and savage dissolve within a new, mutually shared, hybrid Gothic myth. The new American Gothic villain has many savage faces, innumerous nationalities, and lifetimes. Just like the cultural trauma of the ongoing state of colonization of the Americas, the villain cannot be overcome by a single individual or an isolated community. But when the Savage Villain, the embodiment of the racial master discourse of othering and denigration, of anxiety and trauma, is attacked jointly, healing can take place. Just as Carr's novel stresses the power of cross-cultural storytelling and myth sharing, Carr's strategy of reiteration creates a truly hybrid and discourse-altering new Gothic story.

\section{Concluding Remarks}

The Gothic is essentially opportunistic. As the writing strategy has the power either to quote and strengthen or to reiterate and erode racialised discourses of otherness and savagery it proves to be ideologically ultra-adaptable. We still encounter embodiments of the villainous savage today:

even if the Civil Rights Movement has caused the demise of simplistic horse operas with the Indians cast as villains, and alleviated much prejudice that Indians and other minority writers face, bigotry is far from dead. ${ }^{17}$

Today we can still encounter Gothic villains composed by those minorities that were denigrated and silenced by the dominant discourse of savage otherness before. Reiteration, the twisted quotation of stereotypical discursive elements by inversion and hybridisation, has created an American Gothic with a powerful postcolonial message in colonial times. 
Asked about his adaptation of the traditional vampire tale, Aaron A. Carr compellingly summarizes the shift of control and power, and also the fun essentially involved in the reiteration process:

[...] I am now on the other side, I was the one with control. I think that is something that Indian people appreciate, when we do take control of our own imagery. And so, in a sense, I took that tradition - the vampire tradition-from where I was, and made it mine. I stretched it and made it work for my own purpose. And that was fun. Murnau's [Nosferatu] imagery was mine too. I could use it. In the same sense Curtis is saying these people are mine and I can manipulate them and I can make them be what I want them to be... And that is what I did with the vampires, with the European images. One of the comments I get from Indian people is 'I didn't know we could do that kind of thing', 'I didn't know we could write about that kind of stuff'. And I think it is because we need to get to the point when we can say: 'this is mine too', 'this film we see, I can take this and mess around with it too. ${ }^{, 18}$

\section{Notes}

${ }^{1}$ The Gothic is far from being limited to prose fiction. Instead, scholars pinpoint Gothic drama and poetry, Gothic art, film, even Internet, and the Gothic's uncanny power to invade all cultural forms thinkable and to produce 'generic hybrids'. Cf. M. Gamer, Romanticism and the Gothic: Genre, Reception, and Canon Formation, Cambridge University Press, Cambridge, 2000, pp. 12 \& 23.

2 S. Tomc, 'Dieting and Damnation: Anne Rice's Interview with the Vampire', Blood Read: The Vampire as Metaphor in Contemporary Culture, J. Gordon \& V. Hollinger (eds), University of Pennsylvania Press, Philadelphia, 1997, p. 96.

${ }^{3}$ M. Edmundson, Nightmare on Main Street: Angles, Sadomasochism and the Culture of Gothic, Harvard University Press, Cambridge, $2^{\text {nd }}$ ed., 1999, p. 17.

${ }^{4}$ M. Lewis, The Monk, Oxford University Press, Oxford, 1998, p. 18.

${ }^{5}$ B. Stoker (illustrated by J. Lee), The Illustrated Dracula, Viking Studio, New York, 2006, p. 37f., chapter 3.

${ }^{6}$ Ibid. p. 16 , chapter 2.

${ }^{7}$ This writing strategy has been discussed under the notion of 'Imperial Gothic'. Brantlinger suggests confining the Imperial Gothic to the period between 1880 and 1914, which roughly represents the heyday of the British Empire; cf. P. Brantlinger, Rule of Darkness: British Literature and Imperialism, 1830-1914, Cornell University Press, Ithaca, 1988. 
${ }^{8}$ H. Walpole, The Castle of Otranto: A Gothic Story, Oxford University Press, Oxford, 1998, p. 108. Cf. also pp. $22 \& 94$.

${ }^{9}$ For a condensed historical overview of the Evil Savage motif (as well as of its counterpart, the Noble Savage motif) c.f. J. Canup, Out of the Wilderness: The Emergence of an American Identity in Colonial New England, Wesleyan University Press, Middletown, 1990.

${ }^{10}$ K. Althans, Darkness Subverted: Aboriginal Gothic in Black Australian Literature and Film, Bonn University Press, Bonn, 2010, p. 69.

${ }^{11}$ For the early Native American context cf. e.g. W. Apess, 'A Son of the Forest: The Experience of William Apess, a Native of the Forest, Written by Himself (1831)'. See also Apess radical text 'An Indian's Looking-Glass for the White Man' which is part of his 'The Experiences of Five Christian Indians of the Pequo'd Tribe (1833)'. All texts are reprinted in On Our Own Ground: The Complete Writings of William Apess, a Pequot, B. O'Connell (ed), Massachusetts University Press, Massachusetts, 1992. For the African-American context, the Gothic underpinnings of F. Douglass, Narrative of the Life of Frederick Douglass, an American Slave, Written by Himself, Norton, New York and London, 1996, are well researched; especially striking is the Gothic depiction of Douglass' childhood initiation through 'the blood-stained gate $[\ldots]$ to the hell of slavery' in chapter 1.

12 All quotations and comments on Soapstone refer to M. Baggett, Soapstone, http://www.booklocker.com, 2004; this edition is referred to in the text as $(S \mathrm{p})$.

${ }_{13}$ All quotations and comments on Eye Killers refer to A.A. Carr, Eye Killers, University of Oklahoma Press, Norman, 1995; this edition is referred to in the text as $(E K \mathrm{p})$.

${ }^{14}$ R. Tillet, 'Your Story Reminds Me of Something: Spectacle and Speculation in Aaron Carr's Eye Killers', ARIEL, Vol. 33.1, 2002, p. 17.

15 M. Arrivé, 'Interview with Navajo-Laguna Novelist and Filmmaker Aaron Albert Carr', Revue de recherché en civilization américaine, Vol. 2, 2010, p. 13.

${ }^{16}$ Carr establishes a direct comparison between the colonial racist denigration of Native Americans and the Irish as savage races. For an in depth analysis of the Savage Irish stereotype in both Europe and the United States see J. Canup, Out of the Wilderness: The Emergence of an American Identity in Colonial New England, Wesleyan University Press, Middletown, 1990. Cf. also N. Ignatiev, How the Irish Became White, Routledge, New York, 1995.

${ }^{17}$ A.R. Velie, 'Gerald Vizenor's Indian Gothic', MELUS, Vol. 17.1, 1991-1992, p. 76.

${ }^{18}$ M. Arrivé, 'Interview with Navajo-Laguna Novelist and Filmmaker Aaron Albert Carr', Revue de recherché en civilisation américaine, Vol. 2, 2010, p. 11. 


\section{Bibliography}

Althans, K., Darkness Subverted: Aboriginal Gothic in Black Australian Literature and Film. Bonn University Press, Bonn, 2010.

Arrivé, M., 'Interview with Navajo-Laguna Novelist and Filmmaker Aaron Albert Carr'. Revue de recherché en civilisation américaine. Vol. 2, 2010, pp. 1-18.

Baggett, M., Soapstone. http://www.booklocker.com. 2004.

Brantlinger, P., Rule of Darkness: British Literature and Imperialism, 1830-1914. Cornell University Press, Ithaca, 1988.

Canup, J., Out of the Wilderness: The Emergence of an American Identity in Colonial New England. Wesleyan University Press, Middletown, 1990.

Carr, A.A., Eye Killers. University of Oklahoma Press, Norman, 1995.

Edmundson, M., Nightmare on Main Street: Angles, Sadomasochism, and the Culture of Gothic. Harvard University Press, Cambridge, $2^{\text {nd }}$ ed., 1999.

Gamer, M., Romanticism and the Gothic: Genre, Reception, and Canon Formation. Cambridge University Press, Cambridge, 2000.

Ignatiev, N., How the Irish Became White. Routledge, New York, 1995.

Lewis, M., The Monk. Oxford University Press, Oxford, 1998.

Stoker, B., The illustrated Dracula. illus. Lee, J., Viking Studio, New York, 2006.

Tillet, R., 'Your Story Reminds Me of Something: Spectacle and Speculation in Aaron Carr's Eye Killers'. ARIEL. Vol. 33.1, 2002, pp. 149-173.

Tomc, S., 'Dieting and Damnation: Anne Rice's Interview with the Vampire'. Blood Read: The Vampire as Metaphor in Contemporary Culture. Gordon J. \& Hollinger, V. (eds), University of Pennsylvania Press, Philadelphia, 1997.

Velie, A.R., 'Gerald Vizenor's Indian Gothic'. MELUS. Vol. 17.1, 1991-1992, p. 75-85. 
Walpole, H., The Castle of Otranto: A Gothic Story. Oxford University Press, Oxford, 1998.

Corinna Lenhardt is a Ph.D. candidate at the American Studies Department of the Westphalian Wilhems-University, Muenster, Germany. In her current project, titled Wild Horror: Reiterating the American Gothic for the Twenty-first Century, she focuses on defining and employing a postcolonial, neo-modern notion of the Gothic in the context of contemporary Native American and African-American literature. 


\title{
Representations of Villainy in Yemeni Fiction
}

\author{
Fawaz Jazim
}

\begin{abstract}
This chapter attempts to examine the nature of villainy in Yemeni fiction by analysing some fictional works by two major Yemeni writers: The Hostage, a novel by Zayd mutee' Dammaj and some selected short stories from At Night a short story collection by Mohammad Muthana. It presents the political regimes in Yemen as possible representations of villainy. These works are selected on the basis that they represent two different political regimes (the imamate and republican) and this is to examine whether the political regime types change the nature of villainy or not. Dammaj's The Hostage is set in the late 1940s when Yemen was still under the atrocity of the autocracy of the Imams. The chapter shows how villainy in this novel is presented through the tragic account of the hostage system as one the imamate instrument of governance. Villainy is described through the tragic experience of the protagonist, a young boy, who is taken hostage by the ruling Imam's soldiers to secure the obedience of his father and his tribe. Muthana's short stories present the republican political regime as an expression of villainy. The absence of law, empowerment of tribal sheikhs in exchange of their allegiance to the republican regime, imprisoning and oppressing political dissent, and the ruler's extravagant lifestyle and indifference to his national issues are all themes that are employed in this chapter as expressions of villainy. As villains do not work alone, the chapter also examines the nature of servant-villains. The conclusion argues that villainy remains of the same nature whatever the type of the political regime may be.
\end{abstract}

Key Words: Villainy, political regimes, hostage system, sheikhs, Imamate.

$* * * * *$

Attempting to explore the nature of villainy in Yemeni fiction, the one fact upon which my thesis rests can be stated simply enough: political regimes in Yemen can be presented as possible representations of villainy. The works of fiction analysed in this chapter, Zaid Mutee Dammaj's novel, The Hostage and Muhammad Muthana's three short stories are set in two different historical and political periods (Yemen before and after the 1962 revolution), and thus represent two different political regimes (the Imamate and the republican regimes).

To begin with Dammaj's The Hostage, this novel mainly exposes the hostage system that existed during the reign of the Imamate (1904-1962) and according to which the Imam had got the right to take the young boys from powerful tribes to secure the obedience of their fathers. ${ }^{1}$ The novel is a tragic account of a boy from the countryside taken hostage by the ruling Imam's soldiers and imprisoned 'in the 
fortress of al-Qahira, ${ }^{2}$ where he and the other hostages are taught by the faqih ${ }^{3}$ the Holy Quran and how to be obedient prisoners. Then the boy is sent forcefully to serve at the Imam's Governor's palace. There he comes to experience a hostile atmosphere of decadence, injustice and humiliation created and controlled by the palace women, its soldiers and the Imam's Governor. The last open-ended scene of the novel depicts the hostage boy running away from that deadly and oppressive atmosphere. This hostage system represents the clear manifestation of the villainy of the Imamate regime in the novel.

The villainy of the Imamate regime is seen from the perspective of the protagonist, the hostage boy, who in his narration of his personal suffering and agonies as hostage uncovers the horrific realities of the ruling family in different spaces and milieus, the prison and the governor's palace. These horrific realities begin right in the first few lines of the novel: 'his [Imam's] soldiers had come ... and torn me from my mother's lap and the arms of the rest of my family'. ${ }^{4}$ The Imamate regime's indifference to the close emotional relationship that develops between the parents, particularly the mother, and children and which preserves its moving appeal not only in the Yemeni culture but in most cultures is no less than an act of villainy. Dammaj even shows how the memory of the great but vain efforts of the hostage's mother to save him from being kidnapped is still clear in his mind: 'I remembered my mother who'd fled with me from the guards of the Crown Prince ... For all her efforts, I'd been torn from her arms with a cruelty she hadn't known before'.

Perhaps the most villainous act of the imamate regime is the imposition of a new identity on the kidnapped boy. This imposed identity has connotations of enslavement, humiliation and contempt. This is how the hostage boy describes it:

They have oppressed me and attacked my family seizing everything [my freedom and my name] and transforming me into a hostage, then a duwaydar ${ }^{6}$ in her [Governor's sister] and the servant of her brother, the Governor.

Nowhere in the novel is the hostage boy called by his name, in fact the name is not mentioned at all. Throughout the novel he is known as the hostage and the duwaydar, names that continuously indicate his inferior status in the prison and the palace.

There is no doubt that this new identity entails the stripping of one's freedom. This is what the hostage boy bitterly states: 'I've never been free since I was taken to the hostage fortress, and then brought to the palace of our Lord and Master the Governor, and [his sister's] Sharifa Hafsa's house! ${ }^{8}$

It also means being subjected to humiliation and contempt. The life of the hostage boy in the palace represents a series of verbal as well as physical acts of humiliation not only by his masters but also by those people serving in the palace 
who are no less humiliated than him. He, for example, is treated by the driver's of the Imam's car with 'a look of vicious hostility and contempt'. ' On the part of his masters humiliation and contempt are mixed with a sense of domination and superiority. He is always viewed as an object of possession. Sharifa Hafsa addresses him as 'my handsome hostage', ${ }^{10}$ a status that was sometimes confirmed by inflicting punishment on him. There are many instances in the novel in which the soldiers in the palace, ordered by Sharifa Hafsa, put shackles on his legs. ${ }^{11}$ The Governor tells him once in a threatening and humiliating tone: 'don't think ... you can do as you like. You're here as a hostage and a duwaydar'.

The motive behind imposing this identity of the hostage and duwaydar is clear. It is to separate the kidnapped boy from his past, the past of a revolutionary family of courageous people who have rebelled against the Imam. It is to create an individual who is as obedient and brainwashed as those people of the Governor who gather at the gates of his palace to honour or support him at time of crisis. ${ }^{13}$ The effect of this kind of identity is reflected in the hostage boy's realization that he becomes unable to 'sing one of the folk songs from my village'. He cannot 'whistle the tune either'. ${ }^{14}$ He even realizes towards the end of the novel that he becomes unaware of his family's revolutionary struggle. ${ }^{15}$

The villainy of the evil Imamate is also demonstrated in its tragic toll on the innocence and vulnerability of the hostages. The hostage boys who are kept in the fortress are sent to the palace to serve as duwaydara, because they are theoretically 'safe' around the women since they are pre-pubescent. In practice, however, these hostages become 'a focus for sexual exploitation on the part of the older palace women'. ${ }^{16}$ They are sought out by the older women of the palace for unspecified pleasures in the dark. The hostage boy and his friend, the Duwaydar, the novel shows, become victims to "sexualisation' ${ }^{17}$ in which they are sexually objectifiedthat is made into a thing for others' sexual use. Thus there are stories in the novel of these women coming to their room late in the evening kissing them and squeezing further pleasures out of them. ${ }^{18}$ There is also a fierce competition between Sharifa Hafsa and the other women over the hostage boy: 'you're simply jealous of me because he's sitting next to me. Am I jealous of you because he's in your beds every night? ${ }^{19}$ Moreover sexual exploitation is expressed indirectly in Sharifa Hafsa's words to the hostage boy: 'I want to see you become a man ... you haven't proved that yet ${ }^{20}$ and in addressing him as 'an important hostage' and as her 'personal duwaydar'. ${ }^{21}$

It must be noted that 'evil is second-handed'. ${ }^{22}$ The Imamate regime would not survive, acquire and exercise power over the deprived people in the palace and outside it without the help and support of the regime mouthpieces or servantvillains. These are the

negative characters: the climbers, spongers, opportunists, spies, and fake propagandists who contrive a fat living for themselves 
by accommodating the needs of state or of powerful individuals. $^{23}$

A good example of these is the court poet whose job is to recite 'resounding eulogies ... extolling the Imam and the Crown Prince and the Governor too'. ${ }^{24}$ Another example is the soldiers in the palace who represent a constant source of emotional disturbance to the hostage boy and his friend, the Duwaydar, with their (soldiers') 'repeated' and 'mocking' little song: 'your mother, oh duwaydar, is distracted by her loss; her tears fall like rain'. ${ }^{25}$ These soldiers would also work to the satisfaction of the Governor:

in the expectation that the Governor would reward them...by giving them authority over the subjects who were late paying their alms tax and other dues, which would mean profit for them. ${ }^{26}$

In the short stories of Muhammad Muthana the agency of villainy operates within a new and different political regime - the republican regime that came to rule after the 1962 revolution against the Imamate. These stories uncover the grim realities of the corrupt government of the newly formed country.

The story entitled 'Stars did not Drive Away our Melancholy' exposes the villainy of the institution of prison through highlighting the miserable conditions of six political prisoners. ${ }^{27}$ Generally, the villainy of this institution is clearly reflected by the aggressive atmosphere of the prison, particularly the walls of the cell that are described as 'terrible nightmares standing over our heads' and as 'malignant mouths, mouths of death.' The deadly and hard-to-bear footsteps of the rough shoes of the guard in the yard', 'the outside darkness baring its black claws' and 'the awful smell of the damp blankets ${ }^{28}$ are all images that contribute to the creation of a horrible atmosphere.

In this evil atmosphere the prisoners are presented as running a life in death. The story opens with Ali Qaid, a prisoner, being at the death's door. He is not provided with any medical treatment, not 'even an aspirin to relieve his pain': 'Sergeant, Ali Qaid is dying. / [ironically] May Allah be merciful upon him'. ${ }^{29}$ The death of Ali Qaid causes horror to prevail in the cell: 'horror is clearly expressed in our eyes'. It is also articulated in Al-wisabi's words describing 'politics' as being 'mostly funerals' and 'the art of lionesses and the morality of wolves'. And this is why he concludes: 'we are certainly dead here'. ${ }^{30}$

The duty of the prison guards, servant-villains, is not only to treat the prisoners with indifference. It is also to subject them to humiliation:

- Sergeant, somebody has passed away

- What is the name of that who has gone to hell ... 
- Ali Qaid

- The guard picked up cigarette paper foil on the ground and wrote the name of the deceased

- Switch off the lights and sleep otherwise you know what. ${ }^{31}$

The only thing that the prisoners can do to escape their reality, 'darkness and ghosts' is to 'try to forget' and to indulge in dreams. ${ }^{32}$ But in that night this becomes impossible. They are haunted by images of the face of their deceased friend and by fear of death: 'we noticed that it was a dark and dreadful night. The starlight was trying to penetrate ... but our souls did not respond to it that night' ${ }^{33}$

The story 'When Things Mingle' is another example that shows the chaos and corruption in the political regime. It reveals the Sheikhs' domination over and oppression of the poor people in the Yemeni society particularly in the rural areas while the government is turning a blind eye. ${ }^{34}$ Omar is a poor farmer in the village, whose land, his only source of living, has been usurped by Sheikh Bakhit using the government authority and power. Omar is surrounded by soldiers who rub the rifle butts on his back:

- You have no business with Sheikh Bakhit's land.

- This is my land, my footprints are clear there, my sweat and my father's

- Leave it or we'll take you.

- Where will you take me to?

- To prison...to a pit to bury you in... ${ }^{35}$

The loss of his land evokes a hostile and frightening atmosphere expressed by a series of daunting images of hunger: 'starving birds hovering over a donkey skeleton', 'the empty baskets of grains and corn in the village souk', etc. Omar comes to realize that 'this must be the famine time'. ${ }^{36}$ These images of hunger reflect not only the people's hunger for victuals. They also emblematise their hunger for a just political regime, for equality and care and for law and justice.

However the irresponsible government is busy celebrating the Tree Day, planting trees 'in the wide streets that are crowded with cars and foreign tourists'. 37 The author's mention of 'foreign tourists' is very suggestive. It indicates that the regime is only concerned with projecting itself at the international level as a 'competent' regime in a 'prosperous country' rather than eliminating the suffering that Sheikhs inflect on the poor citizens.

Muthana's last story is 'The Memories of Prince S'. It uncovers the villainy of the head of the political regime (president). The story recounts his pleasant memories of his official visit to the USA. These memories do not reflect his concern to promote and support the national interests of his country. They basically show how his visit is a good chance to satisfy his overwhelming desires. He has 
good memories for the face of '(Jacqueline), the most famous American model' and the New Yorkers' fatty food. ${ }^{38}$

Although the outcomes of his official visit are politically 'disappointing' as he admits, ${ }^{39}$ he does not feel conscience-stricken. Instead he suffered intestinal pricking as a result of the New Yorkers' fatty food. ${ }^{40} \mathrm{He}$ even gave a lavish party when he came back in which he, his 'entourage' and 'guests' drink 'in honour of safe return, talks, White House ....' ${ }^{41}$

For president ' $\mathrm{S}$ ', speaking about political issues creates 'a state of tension and disgust' and that is why he curses his minister of endowments when he speaks about politics. $^{42}$ As a result of lack of intimacy between him and politics, his speech at the lavish dinner banquet is apolitical:

He expressed...the great affection his wife has for the host president's wife...He wishes more development and progress for the two countries and looks forward to more personal meetings... ${ }^{43}$

His Excellency then says nothing. In pure egotism he simply eats, drinks, defecates and sleeps.

In conclusion, it might be noted that though two different political regimes with different styles of operation are examined above, the villainies of these political regimes are of the same nature. As villains these political regimes are oppressive and above all 'with respect to others and the rest of the world- they simply do not care'. ${ }^{44}$ They 'lack empathy, the ability to feel for others, to see themselves as part of a larger whole'. ${ }^{45}$

\section{Notes}

1 This hostage system is borrowed by the Imamate regime from the Ottoman Turkish occupiers of Yemen to strengthen the imamate state. See R. Burrowes, 'Prelude to Unification: The Yemen Arab Republic, 1962-1990', International Journal of Middle East Studies, Vol. 23, 1991, p. 485.

${ }^{2}$ Z. Dammaj, The Hostage, trans. M. Jayyusi \& C. Tingley, Interlink Books, New York, 1994, p. 23.

${ }^{3}$ A religious teacher.

${ }^{4}$ Dammaj, op. cit., p. 23.

${ }^{5}$ Ibid., pp. 124-125.

${ }^{6}$ A boy hostage who is sent to one of the palaces of the Imam or those of his princes and governors. This boy hostage should not have reached the age of puberty so that they do not indulge in shameful acts of the sexual sort with the women of the palace. The plural is duwadera. These duwadera 'do the work done 
by the tawashiyeh, or eunuchs...that these were castrated slaves.' See Ibid., pp. 2425.

${ }^{7}$ Ibid., p. 140.

${ }^{8}$ Ibid., p. 119.

${ }^{9}$ Ibid., p. 92.

${ }^{10}$ Ibid., p. 106.

${ }^{11}$ Ibid,. pp. $60,65 \& 108$.

${ }^{12}$ Ibid., p. 115.

${ }^{13}$ Ibid., p. 138.

${ }^{14}$ Ibid., p. 135.

${ }^{15}$ Ibid., p. 136.

${ }^{16}$ S. Jayyusi, 'Preface', The Hostage, trans. Z. Dammaj, M. Jayyusi \& C. Tingley, Interlink Books, New York, 1994, p. x.

17 A. Alzirai, 'The Sociological and Romantic Dimensions in The Hostage: Narration as Vision for place and Society', Zaid Mutee Dammaj: Critical Studies and Readings, Yemeni Writers Union, Sana'a, 2009, p. 241.

${ }^{18}$ See Z. Dammaj, The Hostage, op. cit., pp. 34, 49 and 87.

${ }^{19}$ Ibid., p. 104.

${ }^{20}$ Ibid., pp. 96-97.

${ }^{21}$ Ibid., p. 125.

22 A. Bernstein, 'Villainy: An Analysis of the Nature of Evil' Andrew Bernstein.net, 2009, 30 Apr. 2010, http://www.andrewbernstein.net/articles/34 villainy.htm.

${ }^{23}$ S. Jayyusi, 'Preface', op. cit., p. xii.

${ }^{24}$ Z. Dammaj, op. cit., p. 78.

${ }^{25}$ Ibid., pp. 36, 38,49 \& 110.

${ }^{26}$ Ibid., p. 65.

27 This short story is greatly informed by the author's own experience. Being a political dissenter, the author himself was imprisoned by the regime several times in the 1970s.

${ }^{28}$ M. Muthana, 'Stars did not Drive away our Melancholy', At Night, Ubadi Centre for Studies and Publication, Sana'a, 2003, pp. 100-101.

${ }^{29}$ Ibid., p. 96.

${ }^{30}$ Ibid., p. 98.

${ }^{31}$ Ibid., p. 99.

${ }^{32}$ Ibid., pp. 100-101.

${ }^{33}$ Ibid., pp. 101-102.

${ }^{34}$ According to Burrowes, 'the balance of power between the tribal periphery and the state at the centre tipped back toward the tribes over the course of the civil war' that broke out after the revolution of 26 September 1962. 'The territory that imamate Yemen had embraced was quickly divided de facto among the 
Republicans, the Royalists, and the tribal sheikhs, the last coming to see autonomy and subsidies as the fruits of playing the two competitors for the state off against each other.' The reconciliation that finally marked the end of the civil war in 1970 'involved for the first time the granting of high state office to leading tribal figures in exchange for their allegiance to the republic. Although this incorporation of the tribalists nominally extended the domain of the state, the power of the regime ... was in fact more apparent than real in the tribal heartland to the north and east of San'a'.' See R. Burrowes, 'Prelude to Unification: The Yemen Arab Republic, 1962-1990', International Journal of Middle East Studies, Vol. 23, 1991, p. 486.

${ }^{35}$ M. Muthana, 'When Things Mingle', At Night, Ubadi Centre for Studies and Publication, Sana'a, 2003, p. 108.

${ }^{36}$ Ibid., p. 106.

${ }^{37}$ Ibid., p. 105.

${ }^{38}$ M. Muthana, 'The Memories of Prince S', At Night, Ubadi Centre for Studies and Publication, Sana'a, 2003, pp. 126 and 129.

${ }^{39}$ Ibid., p. 127.

${ }^{40}$ Ibid., pp. $126 \& 128$.

${ }^{41}$ Ibid., p. 127.

${ }^{42}$ Ibid., pp. 127-128.

${ }^{43}$ Ibid., p. 129.

${ }^{44}$ M. Alsford, Heroes and Villains, Baylor University Press, Texas, 2006, p. 121.

${ }^{45}$ Ibid., p. 120.

\section{Bibliography}

Alsford, M., Heroes and Villains. Baylor University Press, Texas, 2006.

Al-ziriai, A., 'The Sociological and Romantic Dimensions in The Hostage: Narration as Vision for place and Society'. Zaid Mutee Dammaj: Critical Studies and Readings. Yemeni Writers Union, Sana'a, 2009.

Bernstein, A., 'Villainy: An Analysis of the Nature of Evil'. Andrew Bernstein.net, 2009, Viewed on 30 April 2010, http://www.andrewbernstein.net/articles/34 villainy.htm.

Burrowes, R., 'Prelude to Unification: The Yemen Arab Republic, 1962-1990'. International Journal of Middle East Studies. Vol. 23, 1991, pp. 483-506.

Dammaj, Z., The Hostage. Trans. Jayyusi, M. \& Tingley, C., Interlink Books, New York, 1994. 
Jayyusi, S., 'Preface'. The Hostage. Interlink Books, New York, 1994.

Muthana, M., 'Stars did not Drive Away our Melancholy'. At Night. Ubadi Centre for Studies and Publication, Sana'a, 2003.

-, 'When Things Mingle'. At Night. Ubadi Centre for Studies and Publication, Sana'a, 2003.

—, 'The Memories of Prince S'. At Night. Ubadi Centre for Studies and Publication, Sana'a, 2003.

Fawaz Jazim is an assistant professor of English in the Department of English, Faculty of Arts and Humanities, Sana'a University, Sana'a, Yemen. He is mainly interested in exploring how literature is a statement of community. 



\title{
A Spanish Incarnation of Cain: Miguel de Unamuno's Abel Sánchez
}

\author{
Santiago Pérez Isasi
}

\begin{abstract}
This chapter aims at exploring the variations of the myth of Cain in Miguel de Unamuno's darkest novel, Abel Sánchez, which, in the words of the author himself, is an exploration on the topic of envy, which he considers to be Spain's 'national sin.' Taking into account both the Bible and Byron's adaptation, Unamuno explores the complex relation between the two brothers (Abel, successful and admired by everybody; and Joaquín - obvious deformation of the original 'Cain'-, his best friend and most envious foe) from the point of view of the 'evil brother,' who is not only aware of his own sin, but fights against it throughout the whole novel. Unamuno's novel illuminates aspects of the myth that are shadowed in the passage from the Bible, such as the ambiguous attitude of Abel towards Cain; Cain (Joaquín)'s own feelings of guilt, even prior to the crime; or the unfair distribution of success and failure.
\end{abstract}

Key Words: Myth, Spanish novel, Miguel de Unamuno, intertextuality, biblical myth, evil twin, murder, redemption.

$* * * * *$

\section{About the Novel}

Miguel de Unamuno, one of the members of the so-called Spanish 'Generación del 98' (Generation of 1898) wrote his novel Abel Sánchez in 1917 (with a second edition in 1928), approximately in the middle of his career as a novelist: ${ }^{1}$ he had published his first novels by the turn of the century (Paz en la guerra in 1895; Amor y pedagogía in 1902); one of his master narrative works, Niebla, was published just three years earlier, in 1914 (although it was written some years earlier), and he was still to create other major novelistic efforts in the years to follow: La Tía Tula (1921) and San Manuel Bueno, mártir (1930). It could be said, then, that when composing Abel Sánchez Miguel de Unamuno is already in possession of a (extremely) personal novelistic style, crystallized in what he called 'nivolas:' novels which escape $19^{\text {th }}$-century realism by suppressing almost completely any reference to specific spaces and times; by creating deliberately flat characters defined by a chosen set of qualities and who maintain them throughout the whole novel; and by giving more importance to the development of an idea, than to the aesthetic form or narrative structure through which that idea is developed.

Abel Sánchez can be included in this category of 'nivolas,' with some limitations: it does not make any reference to a specific and explicit historical or 
geographical context, and it dwells in depth on the idea of 'envy' and 'evil', incarnated in the role of Joaquín; but it also deepens further than Unamuno's previous novels (lighter and more superficial in their portrait of the human soul) into the psychology of the main characters, and it also presents a more complex narrative and textual structure, with the presence of more than one authoritative voice: that of the narrator and that of Joaquín himself, who talks to us through a 'discovered manuscript' (a narrative trick Unamuno most certainly learned from Cervantes), some of which is integrated into the novel, giving a complementary, sometimes contradictory vision of the actions and thoughts of the characters. ${ }^{2}$

\section{Evil in Intertextuality}

Although in his prologue Unamuno states that 'yo no he sacado mis ficciones novelescas -o nivolescas- de libros, sino de la vida social que siento y sufro -y gozo- en torno mío, y de mi propia vida; ${ }^{3}$ in this case his debt to previous texts is more obvious than ever: firstly, with the biblical myth of Cain and Abel (Genesis $4: 1-16)^{4}$ and secondly, with Lord Byron's play Cain, both of which are explicitly cited in the novel. ${ }^{5}$

In both cases, the question of 'good vs. evil' is presented, although not clearly answered: in the well-known, and rather elliptical, biblical narration, both God's rejection of Cain's offerings and Abel's murder are left unexplained: 'Lord had regard for Abel and his offering, but for Cain and his offering he had no regard' (Gn 4:4-5); 'Cain spoke to Abel his brother. And when they were in the field, Cain rose up against his brother Abel and killed him.' (Gn. 4:8-9). ${ }^{6}$ Cain is a guilty and self-confessed murderer, but the reasons for his actions are unclear: did he kill his brother because of envy, or rage? What did Cain and Abel talk about before the crime?

Lord Byron, in his romantic play, transforms Cain into a self-conscious diabolic rebel, tormented by the idea of death and suffering, tempted and guided by Lucifer, who questions the goodness of a god who creates mortality and condemns the sons for the sins of their fathers. Both Cain's rebellion and Abel's murder are therefore justified by Byron, and he thus fills the gaps in the biblical narration very personally and controversially. God's rejection of Cain's offering is still unexplained (in fact, God has no voice at all in the play), but Cain's rebellion has now a cause, or better yet, two causes: he rebels against God, for creating death and therefore, mortality; and secondly, he rebels against his parents, for committing the sin that condemned all their heirs, and for choosing the Tree of Knowledge over the Tree of Life. In fact, one of the main questions of the play is that of God's own goodness ('Goodness would not make / Evil; and what else hath he made?'), ${ }^{7}$ while Cain's crime comes as a consequence of a heated dispute with his brother (thus being a consequence of a moment of rage, rather than a premeditated act of envy or revenge). Abel, on the other hand, is a rather passive character in all versions: his goodness derives from passivity and ignorance, while 
Cain's evilness seems to relate to his thirst for knowledge and his rebellion against the destiny that is unjustly imposed on him.

Unamuno's novel cannot be said, properly, to be a demystification of the biblical story, but rather a modernization of its motifs and themes, closely following the same direction of Byron: Joaquín (a modern Cain) struggles to understand why society (the contemporary version of God) prefers Abel's effortless qualities as a painter, rather than his skills as a scientist (in clear relation to the idea of thirst for knowledge as the source of Cain's sin in Byron). In fact, both literary precedents are quoted and commented in Unamuno's novel: the Biblical narration in chapter XI, and Byron's adaptation, in the following one. In the first case, both characters discuss the passage because Abel is going to paint a portrait on the subject, and Joaquín, whose identification with the biblical Cain is obvious, tries to put the guilt of the crime on Abel and the 'abelites:'

-¡Ah!, pero tú crees que los afortunados, los agraciados, los favoritos, no tienen culpa de ello? La tienen de no ocultar, y ocultar como una vergüenza, que lo es, todo favor gratuito, todo privilegio no ganado por propios méritos, de no ocultar esa gracia en vez de hacer ostentación de ella. $(A S, 121)^{8}$

The reading of Byron's Cain, on the other hand, is done by Joaquín alone, although it is suggested by Abel, who uses it as a source for his painting. Joaquín, through Byron, identifies himself even more deeply with Cain, his suffering and his sin, his devilish hate:

Hasta que leí y releí el Caín byroniano, yo, que tantos hombres había visto agonizar y morir, no pensé en la muerte, no la descubrí. Y entonces pensé si al morir me moriría con mi odio, si se moriría conmigo o si me sobreviviría [...] Todo lo que mi ciencia no me enseñó me enseñaba el terrible poema de aquel gran odiador que fue lord Byron. $(A S, 124)^{9}$

The relation between Unamuno's Abel Sánchez and its predecessors, then, is more than a mere influence or a subtle intertextuality: it is rooted in the center of the novel, and it radically conditions the configuration of its main characters and plot. It would be impossible to understand Abel Sánchez and its questioning of the meaning of good and evil, without knowing the biblical text and Byron's reinterpretation.

\section{Joaquín / Cain: The Self-Conscious Villain}

But we still have not answered what could be considered the key question regarding the topic of this meeting: is Cain evil? Can he be considered guilty, 
sinful, morally corrupt? Or can we blame God, or Satan, or Abel himself, for his sins? Is he just a perverse individual, or the representation of a philosophical or anthropological kind of 'original sin' common to all humankind? All the texts that deal with Abel and Cain's myth are highly ambiguous in this aspect: in the Bible, we could argue that Cain is irrationally envious, violent, arrogant; in Byron's play, on the other hand, his acts are explained, if not justified (and he is the first one to feel guilt and remorse after the deed is done). And what about Unamuno's Joaquín? Can we blame him for killing Abel, as in the previous versions? Or is Abel to be blamed? Or some superhuman force of some kind (Satan, destiny, society)? In fact, Unamuno's version is the most ambiguous of all: the only character that is convinced of Joaquín's evilness is Joaquín himself.

This ambiguity about the roots and causes of Joaquín's envy is skillfully maintained through the whole novel. In the first chapter, Joaquín informs us that Abel was always, even as a child, more popular than him: 'Ya desde entonces era él simpático, no sabía por qué, y antipático yo, sin que se me alcanzara mejor la causa de ello, y me dejaban solo' $(A S, 86) .{ }^{10}$ In that same chapter, Joaquín, mirroring Anselmo's mistake in Cervantes's El curioso impertinente, introduces Abel to his girlfriend, Helena (the name, again, has evident literary resonance), and she effortlessly and inevitably falls in love with him; but apparently Abel cannot be blamed for this either:

-Te juro que, si en mí solo consistiese, Helena sería tu novia, y mañana tu mujer. Si pudiese cedértela... [...] Te la cedería gratis y gozaría en veros felices, pero...

-Sí, que ella no me quiere y te quiere a ti, ¿no es eso?

- iEso es!

-Que me rechaza a mí, que la buscaba, y te busca a ti, que la rechazabas.

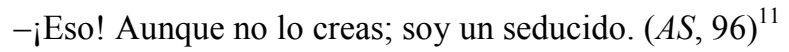

This love triangle could be considered the origin of Joaquín's hate towards Abel; however, he considers that this hate doesn't come from his own mind or soul, but from somewhere or somebody else (¿God, Satan, his ancestors...?): ‘¿Qué hice yo para que Dios me hiciese así, rencoroso, envidioso, malo? ¿Qué mala sangre me legó mi padre?' $(A S, 136) .{ }^{12}$ Thus, Joaquín/Cain's evilness is presented as an external force that drives him and is superior and previous to him. In fact, for the rest of the novel, Joaquín tries, alternatively, to defeat Abel in any imaginable field, or to sublimate his hate, with the help of his wife, Antonia, through science, religion, and, finally, through their descendants -a son for Abel and Helena; a daughter for Joaquín and Antonia-: 
Le dio Antonia a Joaquín una hija. 'Una hija -se dijo-. ¡Y él un hijo!' Mas pronto se repuso de esta nueva treta de su demonio. Y empezó a querer a su hija con toda la fuerza de su pasión y por ella a la madre. 'Será mi vengadora', se dijo primero, sin saber de qué habría de vengarle, y luego: 'Será mi purificadora'. ( $A S$, $127)^{13}$

But all attempts are in vain: Joaquín's envy and hate towards Abel always come back to chase and torture him. It could be said, then, that Abel Sánchez is the story of an addiction (an addiction to hate and envy) and the unsuccessful efforts to overcome it. It is only thanks to the mixture of their bloods (Abel's and Joaquín's) and through the love of his grandson, that Joaquín hopes to be able to triumph over hate: 'Veía en ello mi salvación. Solo uniendo tu suerte a la suerte del hijo único de quien me ha envenenado la fuente de la vida, sólo mezclando así nuestras sangres esperaba poder salvarme.' $(A S, 177) .^{14}$

And it is in this new phase of hope and forgiveness that the novel gets to the culminating point in the mythological narrative of Abel and Cain: Abel's murder. Unamuno is, once again, deliberately ambiguous when describing the crime. As in Byron's poem, it is caused by a confrontation and by anger; but Joaquín's responsibility in Abel's death is much more diffuse than in the other versions: he tries to kill his friend, but quickly repents and retreats (although Abel dies, of a heart attack caused by Joaquín's violence):

Levantóse entonces Joaquín, lívido, se fue a Abel, y le puso las dos manos, como dos garras, en el cuello, diciendo:

-¡Bandido!

Mas al punto las soltó. Abel dio un grito, llevándose las manos al pecho, suspiró un ‘¡Me muero!' y dio el último respiro. Joaquín se dijo: ' $¡ E l$ ataque de angina; ya no hay remedio; se acabó!' $(A S$, $201-2)^{15}$

Are we now, after briefly reviewing the plot and characters in Abel Sánchez, qualified to judge Abel's behavior as guilty or evil? We would surely reduce the interest of the novel if we did so without some clarification. Firstly, as we have seen, Joaquín, just like Cain, is rejected both by his peers and by Helena, for no apparent reason ('nací condenado'. $A S, 44){ }^{16}$ this creates in him a feeling of guilt, envy, and anger that pursues him through his whole life; the fact that he tries, through different escapes, to sublimate or overcome his anger with no success shows that this hate is more powerful than him and is imposed on him by some external, unknown agent. Even in the act of killing, Joaquín is shown as a divided being: the one that attacks Abel, and the one that instantly regrets it and pulls back. In brief, Unamuno is apparently telling us that, if Joaquín (Cain) is evil, it is 
because of an unjust fate that makes him so; if he is consumed by envy, it is because there is nothing he can do to avoid it; if he is murderous, it is because there is only so much that a man can do against the force of a consuming passion.

\section{Epilogue: Envy, a National Sin?}

As we have seen so far, Joaquín's sin can be considered as a psychological, perhaps anthropological kind of evil. His motives can be considered individual or universal, depending on the point of view of the analysis; however, Unamuno also hints at another interpretation of Joaquín's actions and of his reasons for writing the novel: that Joaquín is consumed by the Spanish national sin: envy.

This interpretation is only very subtly introduced in the text of the novel: in its last chapter, when Joaquín has already committed his crime, he turns towards his family, and reflects on his life in these words:

¿Por qué he sido tan envidioso, tan malo? ¿Qué hice para ser así? ¿Qué leche mamé? ¿Era un bebedizo de odio? ¿Ha sido un bebedizo de sangre? ¿Por qué nací en tierra de odios? En tierra en que el precepto parece ser: 'Odia a tu prójimo como a ti mismo'. Porque he vivido odiándome; porque aquí todos vivimos odiándonos. $(A S, 205)^{17}$

However, in 1928 (when he was suffering exile from his country), when writing a prologue for the second edition of the novel, he recovered and amplified this idea, transforming it, somewhat artificially, into the main thesis of the novel:

Salvador de Madariaga, comparando ingleses, franceses y españoles, dice que, en el reparto de los vicios capitales de que todos padecemos, al inglés le tocó más hipocresía que a los otros dos, al francés más avaricia y al español más envidia. Y esta terrible envidia $[\ldots]$ ha sido el fermento de la vida social española. $(A S, 11)^{18}$

It is a suggestive and powerful temptation, to classify nations by their basic sins, or sins by their national predominance; it is a reading, however, that would much impoverish Unamuno's novel, which deals with mythological and anthropological evil, rather than with a national manifestation of it. 


\section{Notes}

1 On Unamuno's narrative, see R.L. Nicholas, Unamuno, narrador, Madrid, Castalia, 1987, and I. Elizalde, Miguel de Unamuno y su novelística, Caja de Ahorros Provincial de Guipúzcoa, San Sebastián, 1983.

${ }^{2}$ Due to limited space in this essay, I will not have time to analyse in detail Unamuno's narrative techniques in Abel Sánchez, with which I already dealt in my previous work: S. Pérez Isasi: 'Construcción narrativa y tiempo en Abel Sánchez de Unamuno', Homenaje a Roberto Pérez (Monográfico Letras de Deusto), Vol. 35, No. 108, July-September, pp. 23-34.

${ }^{3}$ M. de Unamuno: Abel Sánchez, C.A. Longhurst (ed), Cátedra, Madrid, 1995, pp. 79-80. The following quotes from the novel will be identified as $A S$, followed by the page number. Quotes from the Spanish text will be offered in the English translation by John Macklin (Oxbow, Oxford, 2009), which, unfortunately, does not include the Prologue to the second edition. I offer, then, my own translation of this passage: 'I have not taken my novelistic -or nivolistic- fictions from books, but from the social life that I live and suffer -and enjoy- around me, and from my own life'.

${ }^{4}$ There are other Judaic and Islamic versions of the myth of Cain and Abel, but the one that Unamuno used as a source is obvious and explicitly the canonical biblical version.

${ }^{5}$ T.R. Franz has found yet other significant intertexts: Emilia Pardo Bazán's $L a$ Madre Naturaleza, Emily Bronte's Wuthering Heights, Milton's Paradise Lost (although it could be argued that in this case Byron's poem acts as a mediator), and Wilde's The Picture of Dorian Gray. All these intertexts may be traceable in Unamuno's novel, but they are not, as I think it is obvious, its thematic or even formal main precedents. Cf. T.R. Franz, Parallel but Unequal: The Contemporizing of Paradise Lost in Unamuno's 'Abel Sánchez,' Valencia: Albatros/Hispanófila, 1990; 'Abel Sánchez and Wilde's The Picture of Dorian Gray: The Case of a Selective Intertext,' Letras Peninsulares 16.3, 2003-2004, pp. 727-741; and 'Transforming Wuthering Heights and La Madre Naturaleza into Abel Sánchez: Creating the Postmodern out of Its Past,' Decimonónica, Vol. 3, No. 2 (Summer 2006), pp. 27-44.

${ }^{6}$ English Standard Version Bible, Last accessed 19/07/10, http://www.esv.org/.

${ }^{7}$ Lord Byron: Cain, Gutenberg Consortia Center, Last accessed 10 August 2010, http://worldlibrary.net/eBooks/WorldeBookLibrary.com/cainbyron.htm.

8 'But do you really think that the fortunate ones, the chosen ones, the preferred ones, are not to blame? They deserve blame because they do not hide, and hide like something shameful, every gratuitous favour, every privilege not gained by their own merit. They are guilty because they don't that favour, but rather make a show of it'. M. de Unaumno, Abel Sánchez, J. Macklin (trans. and introduction), Oxbow Books, Oxford, 2009, p. 87. 
9 'Until I read and re-read Byron's Cain I, who had seen so many persons suffer and die, did not think of death. I had not discovered it. And then I wondered if, when I died, my hatred would die with me, whether it would die with me or whether it would survive. I wondered if hatred survived those who hate, whether it is something enduring which is transmitted from one person to another; whether it is the soul, the very essence of the soul. And I began to believe in Hell, and in death as a being, the Devil, Hatred made flesh, as the God of the soul. Everything that my science could not teach me, the terrible poem of that great hater, Lord Byron, taught me'. J. Macklin, op. cit., p. 91.

10 'From them on, he was the popular one, why, I don't know, and I the unpopular one, without my having any idea why this should be so, and they left me alone. From childhood my friends isolated me'. Ibid., p. 29.

11 'I swear that if it were up to me, Helena would now be your fiancée and tomorrow your wife. If I could give her to you [...] I would give her to you for nothing, and I would be pleased to see you happy, but...'

'But, she doesn't love me and she does love you, isn't that it?'

'That's it!'

'She rejects me who pursued her, and she pursues you who rejected her'

'Although you won't believe it, I'm the one who was seduced', J. Macklin, op. cit., p. 45.

12 'What did I do for God to make me like this, rancorous, envious, and evil? What bad blood did my father bequeath to me?' J. Macklin, op. cit., p. 111.

13 Antonia presented Joaquín with a daughter. 'A daughter', he said to himself. 'But he has a son!' But he soon got over this new ruse wrought by his devil. And he began to love his daughter with all the strength of his emotions and, through this love, he came to love the mother also. 'She will be my avenger', he said to himself at first, not knowing that what she had to avenge him for, and then he said: 'She will be the one who purifies me'. J. Macklin, op. cit., p. 95.

14 'I saw my salvation in this marriage. Only by joining your destiny to the destiny of the only son of the man who had poisoned the source of my life, only by mixing our two bloodlines, could I hope for salvation'. J. Macklin, op. cit., p. 177.

${ }^{15}$ Joaquín then got up, in a rage, and went over to Abel and put his two hands around his neck like two claws and said: 'You thief!' But he immediately loosened his grip. Abel let out a scream, clutched his chest with his hands, and said with a sigh, 'I'm dying', and he gave up his last breath. Joaquín said to himself, 'It's angina. There's no way out. It's over!'. J. Macklin, op. cit., p. 215.

16 'I was born damned'. J. Macklin, op. cit., p. 45.

17 'What have I become, so envious, so evil? What have I done to be like this? What mother's milk did I drink? Was it a potion composed of hate? Was it a potion I inherited? Why was I born into a land of hatred, into a land where the rule seems 
to be 'Hate your brother as yourself'? Because I have lived hating myself. Because here we all live hating one another'. J. Macklin, op. cit., p. 219.

${ }^{18}$ Again, John Macklin's translation of the novel does not include this passage, as it is contained in the introduction to the second edition. I offer my own translation: 'Salvador de Madariaga, compairing the English, the French and the Spaniards, says that, in the distribution of capital sins that we all suffer from, the Englishmen received more hypocrisy than the other two; the Frenchmen, more gread, and the Spaniards, more envy. And this terrible envy [...] has been the ferment of Spanish social life'.

\section{Bibliography}

Abellán, J.L., 'Introducción'. Miguel de Unamuno Abel Sánchez. Castalia, Madrid, 1985.

Ayala, F., 'La novelística de Unamuno'. La novela: Galdós y Unamuno. SeixBarral, Barcelona, 1974.

Byron, G.G., Cain. Gutenberg Consortia Center. Last accessed 10/08/10, http://worldlibrary.net/eBooks/WorldeBookLibrary.com/cainbyron.htm.

Clavería, C., 'Sobre el tema de Caín en la obra de Unamuno'. Miguel de Unamuno: El escritor y la crítica, Sánchez-Barbudo, A. (ed), Taurus, Madrid, 1990.

Elizalde, I., Miguel de Unamuno y su novelística. Caja de Ahorros Provincial de Guipúzcoa, San Sebastián, 1983.

English Standard Version Bible, Last accessed 19/07/10. http://www.esv.org/.

Franz, T.R., Parallel but Unequal: The Contemporizing of Paradise Lost in Unamuno's Abel Sánchez'. Albatros/Hispanófila, Valencia, 1990.

- 'Abel Sánchez and Wilde's The Picture of Dorian Gray: The Case of a Selective Intertext’. Letras Peninsulares. Vol. 16, No. 3, 2003-2004, pp. 727-741.

—-, 'Transforming Wuthering Heights and La Madre Naturaleza into Abel Sánchez: Creating the Postmodern out of Its Past'. Decimonónica. Vol. 3, No. 2, Summer 2006, pp. 27-44.

Nicholas, R.L., Unamuno, narrador. Castalia, Madrid, 1987. 
Pérez Isasi, S., 'Construcción narrativa y tiempo en Abel Sánchez de Unamuno'. Homenaje a Roberto Pérez (Monográfico Letras de Deusto), Vol. 35, No. 108, July-September, pp. 23-34.

Unamuno, M. de, Abel Sánchez. Longhurst, C.A. (ed), Cátedra, Madrid, 1995.

—_, Abel Sánchez. Aris \& Philips Hispanic Classics, Oxbow Books, Oxford, 2009.

Santiago Pérez Isasi is currently a post-doctoral researcher at the Centro de Estudos Comparatistas, in the Universidade de Lisboa, with a grant from the Basque Government. His main research interests are Spanish narrative (from Golden Age to $20^{\text {th }}$ century) and $19^{\text {th }}$ and $20^{\text {th }}$ century Literary History. 


\section{PART IV}

Gendered Villainy 



\title{
The Changing Face of the Femme Fatale: Is She Really Villainous?
}

\author{
Burcu Genc
}

\begin{abstract}
Villains and villainy have succeeded in drawing the attention of the reader or audience as much as heroes and their heroic deeds throughout the history of literature and film. They are among the most crucial characters thanks to their functions of not only making heroes' existence possible but also bringing excitement to the whole story. Although our reactions towards villain characters have most of the time been hostile by wanting their punishment or even their death, we can often find such villains who make us believe that the whole story would be less exciting without them. The femme fatale is among that kind of villains because she charms us with her beauty and locks us up inside the story exactly in the same way as she entraps the man victim of her love. This famous villainous woman who is an expert in capturing the attention of everyone wherever she goes will arouse interest one more time in this chapter divided into two main parts. In the first part, the concern will be to retrace the steps of the femme fatale in the Bible looking at women figures such as Lilith and Salome together with their incarnations in Dante Gabriel Rossetti's Body's Beauty and Oscar Wilde's Salome in order to portray the image of the femme fatale in detail. In the second part, my aim will be to compare and contrast James Mallahan Cain's Double Indemnity with Henrik Ibsen's Hedda Gabler together with their movie versions to question if the femme fatale is cruel for the love of maliciousness or not with the help of the portrait that we attained in the first part. I will draw the conclusion that it is the patriarchal structure of the $19^{\text {th }}$ century society that frames her to be villainous.
\end{abstract}

Key Words: Femme fatale, metaphors and patterns, $19^{\text {th }}$ century gender theories.

$* * * * *$

\section{Salome and Lilith as Metaphors of an Ideology}

'Nature is not to be regarded as purposeful..." Likewise, woman was conceived to be without a purpose. '...therefore, she can become everything...,'2 which entails the danger of the unknown. The danger attributed to woman is also evident in the arbitrary scientific theories of the late $19^{\text {th }}$ century on gender which were formed by examining 'the manner in which the female insect devoured the male' to argue that this 'proved that manhood were mere mincemeat to woman..." When woman's capacity to 'become everything, ${ }^{4}$ and her sexuality as a threat to 'the masculine vital essence" ${ }^{5}$ were combined with the lack of 'feminine element ${ }^{\text {" }}$ in religious symbolism and its preconceptions, biblical women figures like Salome and Lilith were incarnated in many literary works in the $19^{\text {th }}$ century. 
Biblical story of the daughter of Herodias lays the foundations for Oscar Wilde's Salome. Salome is only dangerous due to her female seductiveness because Herod promises her "whatsoever [she] shalt ask of [him]. I will give it to thee, unto the half of my kingdom. ${ }^{7}$ The important fact here is that Herod, who owns all the wealth and power as a king, becomes willing to lose half of what he has just to see Salome dancing. Power of female sexuality in this scene becomes even stronger in Oscar Wilde's Salome because Herod, the king, almost comes to the point of begging Salome to dance: 'Salome, Salome, dance for me. I pray thee dance for me... ${ }^{8}$ Herod succumbed to the charms of Salome, which could lead him to his downfall by losing his financial means. In the $19^{\text {th }}$ century when men were associated with reasoning, it intimated them that women were capable of depriving men from all their means by captivating their reasoning with their charm. Likewise, upon her mother's advice, Salome claimed Herod's reasoning by wishing John the Baptist to be beheaded.

Wilde does not adhere to the biblical story completely and he adds a new dimension to it. What we observe in his Salome is the nature of women in the eyes of men in his era. Herod's comment on the moon which is always associated with women- '...she is like a mad woman, a mad woman who is seeking everywhere for lovers...9 - is in parallel with the ideas of Otto Weininger, a 19th century philosopher who is famous for his Sex and Character.

The condition of sexual excitement is the supreme moment of a woman's life. The woman is devoted wholly to sexual matters, that is to say, to the spheres of begetting and of reproduction. ${ }^{10}$

As emphasised in the example of the female insect before, female sexuality was seen to be devouring and depriving male from his vitality. Herod's reason, John the Baptist, does not let Salome kiss him by being careful about her fatal sexuality and evil nature. He can be regarded as Herod's reason due to his role of an advisor to the king. Although his reason, John the Baptist, resists her till the moment he dies, Herod's virility cannot. Thus, Salome, as a femme fatale after money and men's success, becomes a metaphor for Phyllis in Double Indemnity and Ibsen's Hedda.

Female demon of Jewish folklore, Lilith, is, most of the time, associated with 'the screech owl' 11 in the Old Testament. Again a female creature just like the female insect is described with her reproductive side: 'there shall the great owl make her nest, and lay, and hatch, and gather under her shadow... ${ }^{, 12}$ There is no doubt that Dante Gabriel Rossetti, in Body's Beauty, makes use of this biblical story while creating 'the New Woman, free of male control, scourge of the patriarchal Victorian family'. ${ }^{13}$ The life of men who try to be united with Lilith is conceived in danger as in the case of Salome when we consider that: 
Freud, Weininger, and virtually everyone else growing up during the later nineteenth century had been bombarded with speculations concerning the link between semen and blood and most unquestioningly accepted these as scientific truths. ${ }^{14}$

Similarly, Rossetti's Lilith 'draws men to watch the bright web she can weave, /Till heart and body and life are in its hold'. ${ }^{15}$ However, unlike Salome, she is not after power and money. Instead, while she fills herself up spiritually by devouring man till she leaves 'his straight neck bent', ${ }^{16}$ she avoids giving the same affection and love in return. As a result, 'the more the lover will attempt to break down the barriers between them, and the more he attempts to become united with her, the more imprisoned he will be ${ }^{17}$ As loss of semen is equated with loss of blood, the lover will be deprived of his vital energy. In this way, Dante Gabriel Rossetti's Body's Beauty which focuses on the dangers of both female sexuality and beauty in terms of her fatal love creates another type of metaphor with Lilith for Hedda and Phyllis in the minds of the $19^{\text {th }}$ century men.

\section{Hedda and Phyllis as Patterns}

It is necessary to look at both Hedda and Phyllis closely to understand why they are believed to be villainous. For this reason, I will first try to show how they relate to Salome and Lilith. While Hedda is Salome when she gets ahead of Lovborg's success by burning his notes, encourages him to kill himself, it is possible to call Phyllis Salome for her ambition to kill her husband and get his money. Hedda is not only Salome but also Lilith because she never responds back to Lovborg's love and passion. However, differently from Lilith, she does not kill him herself because of her 'fear of scandal'. ${ }^{18}$ Instead, she brings him to the point of committing suicide. What Lovborg says to Hedda in their first meeting after her marriage-

Do you remember, Hedda, all those wild things I confessed to you? Things no one suspected at this time- my days and nights of passion and frenzy, of drinking and madness- How did you make me talk like that, Hedda? By what power $?^{19}$

-shows clearly how this unrequited love has brought him down. More importantly, the biggest fear of the late $19^{\text {th }}$ century's men had, women's power over men, underlies Lovborg's words. Here comes into the scene the danger of the unknown because Lovborg cannot make any sense of how Hedda has managed to have such a power over him. For this reason, Hedda is a perfect femme fatale within the framework of the late $19^{\text {th }}$ century theories on gender.

Rather than acting as the femme fatale directly towards her husband, Phyllis victimizes Walter. Walter's inner monologue in response to the offer of tea- 'the 
white sailor suit did it. I sat down ${ }^{20}$ - clearly shows Phyllis is up to victimizing Walter rather than her husband by using her sexuality over him. Walter ends up ruining his career at the end; it is 'straight down the line" ${ }^{21}$ for him. However, Phyllis cannot become Lilith. It is true that she draws Walter to herself but it is not alone her beauty and her love alone that bring destruction upon him. From the very beginning, Walter is aware that 'she wasn't saying what she meant. ${ }^{22}$ Nevertheless, he cannot help by yielding to 'that thing...in [him], pushing [him] still closer to the edge. ${ }^{23}$ Secondly, Walter is willing to help Phyllis kill her husband. He tells it even before Phyllis says it openly. 'What would you do this for ${ }^{24}$ asks Phyllis. He replies saying that he would do it for '[her], for one thing' and 'money. ${ }^{25}$ Walter's motives are not only out of love. For this reason, Walter is not only a victim but also a perfect crime partner.

To define both Hedda and Phyllis as femmes fatales and leave the subject there would be too superficial. Both Hedda and Phyllis are 'fatefully entrapped in a claustrophobic world and unable to master their destinies. ${ }^{26}$ Although their motives are different, both of them try to control the inevitable destiny ahead of them. The main reason of entrapment is the state of being reduced to patterns of Salome and Lilith. As Bram Djisktra puts forward, "metaphors do the dirty work of ideology. They telescope complex ideas into simple imagery and encourage us to see others not as persons but as patterns' ${ }^{27}$ For this reason, both Hedda and Phyllis are only patterns while Salome and Lilith are their metaphors. Neither Hedda nor Phyllis has their own essence but they are merely villainous patterns trying to control others not out of their maliciousness but just to claim their own freedom. However, when Thea says that she 'began to have power over [Lovborg]', ${ }^{28}$ the reaction Hedda gives which is mixed with shock and disappointment shows that both Hedda and Phyllis have chosen the wrong path for this aim. ${ }^{29}$ Contrary to the fears about free and powerful women, this shows that the loyal woman who is dependent on her man can have power over him as in the case of Thea.

Moreover, arguing that Hedda burns Lovborg's notes out of maliciousness or sheer jealousy can only be one of the ways of interpreting the action. Alternatively, she burns them because Lovborg gives up everything due to the guilt he feels towards another person when he loses his notes. The issue is not that this person is Thea but that it is Lovborg's feeling of responsibility towards someone else which defines his actions on a matter, which will affect his life. In other words, he does not act like a subject but an object responsible towards somebody else when it comes to his self-realization. The man who symbolizes self-realization disappoints Hedda by considering Thea first rather than himself. As Lovborg says, he couldn't even bring himself to tell Thea. ${ }^{30}$ Arthur Ganz comments on the issue by giving both Hedda and Nora, Ibsen's two heroines, as an example:

Both heroines dream of achieving self-realization by seeing an admired man perform an act of extraordinary courage. In each 
play the failure of the man to do what the heroine desires precipitates her decision to take her destiny into her own hands and separate herself drastically from the life she has previously known. ${ }^{31}$

Hedda burns the notes and encourages him to kill himself by giving the gun when she sees that there is no hope for him. Similarly, at the end she kills herself when she feels that there is no hope to be free because Judge Brack figures out that Hedda is the one who gave the gun to Lovborg.

Likewise, Phyllis does not act like a femme fatale for the love of maliciousness. As the whole story is told by Walter, we do not have any information about Phyllis' real motives. Moreover, to consider the relationship between Phyllis and Walter as a conditioned one will give us a different perspective. The conversation between Phyllis and Walter when he is about to leave the house implies that they are just acting a scene that they are supposed to:

Walter Neff: You'll be here too?

Phyllis: I guess so, I usually am.

Walter Neff: Same chair, same perfume, same anklet?

Phyllis: I wonder if I know what you mean.

Walter Neff: I wonder if you wonder. ${ }^{32}$

What Walter says at the end of this conversation with an ironic smile on his face supports and confirms the idea of a conditioned relationship and its being mere act. They both know what they are up to and what will come next. Thus, neither Phyllis nor Walter is actually themselves but patterns of what they are believed to be. Moreover, when Walter kisses Phyllis while talking about how they will kill her husband, it is as if he is kissing her passionately with the excitement that he gets from the idea of killing the husband..$^{33}$ As a result, while Phyllis is not but acting a fantasized villainous woman unlike in late $19^{\text {th }}$ century's theories on gender, Walter's case turns out to be 'a failed desire. ${ }^{34}$

\section{Conclusion}

In the $19^{\text {th }}$ century, '... mapping of the female body... coincide[s] with a broader ideological drive by capitalism to mark out gender differences and establish marriage and the home as the central institutions of society'. It is again in the $19^{\text {th }}$ century when it was put forward that '... woman demands that man should clear her confusion of thought, give meaning to her henid ideas ${ }^{35}$ by turning them into an object that needed to be instructed in order to be good. For this reason, it is no surprise that the stories of villainous women figures, Salome and Lilith, went beyond their Biblical ones in their incarnations. They became the prototypes of villainous woman, the femme fatale, with their sexual power over men. Theories 
on women were generalized in such a way that scientists almost turned women into empty vessels. Ibsen's Hedda and Cain's Phyllis are one of the best examples of such generalizations. Their motives have, most of the time, been examined by just looking at the pattern rather than the real person. It is not yet fully understood that Hedda and Phyllis, in the life that entrapped them, could not find a way to independence other than trying to exercise their power over men because this is the only thing that they are capable of and they have been taught. These women turn into villainous patterns so long as they align themselves with the patriarchal roles in the society of the $19^{\text {th }}$ century and read within the framework of the theories on gender in this period.

\section{Notes}

M.D. Fritz Wittels, 'Goethe and Freud', Freud and His Time, Liveright, New York, 1931, p. 35.

2 O. Weininger, 'Woman and Her Significance', Sex and Character, Kessinger Publishing, New York, 2007, p. 294.

${ }^{3}$ B. Djisktra, 'Vital Essence and Blighting Mildew', Evil Sisters: The Threat of Female Sexuality and the Cult of Manhood, Alfred A. Knopf, New York, 1996, p. 51 .

${ }^{4}$ Weininger, op. cit., p. 294.

${ }^{5}$ Ibid., p. 51.

6 A.B. Ulanov, 'Religion and the Psyche: The Symbol and Theology', The Feminine in Jungian Psychology and in Christian Theology, Northwestern UP, Evanston, 1971, p. 109.

7 'New Testament: Mark', Holy Bible: Old and New Testaments, Tophi Books, London, 1994, p. 20.

${ }^{8}$ O. Wilde, Salome, J. J. Little \& Ives Company, New York, 1935, p. 92. ${ }^{9}$ Ibid., p. 64.

${ }^{10}$ O. Weininger, 'Male and Female Sexuality', Sex and Character, Kessinger Publishing, New York, 2007, p. 88.

11 'Old Testament: Isaiah', Holy Bible: Old and New Testaments, Tophi Books, London, 1994, p. 303.

12 Ibid., p. 303.

${ }^{13}$ V.M. Allen, 'One Strangling Golden Hair: Dante Gabriel Rossetti’s Lady Lilith', The Art Bulletin, Vol. 66, June 1984, p. 287.

14 B. Djisktra, 'For the Blood is the Life', Evil Sisters: The Threat of Female Sexuality and the Cult of Manhood, Alfred A. Knopf, New York, 1996, p. 87.

${ }^{15}$ D.G. Rossetti, 'Body's Beauty', Collected Prose and Poetry, J. McGann (ed), Yale UP, New Haven, 2003, p. 161.

${ }^{16}$ Ibid., p. 162. 
${ }^{17}$ S.J. Spector, 'Love, Unity, and Desire in the Poetry of Dante Gabriel Rossetti', ELH, Vol. 38, September 1971, p. 439.

${ }^{18}$ H. Ibsen, Hedda Gabler, New York UP, New York, 1955, p. 137.

${ }^{19}$ Ibid., p. 135.

${ }^{20}$ J.M. Cain, Double Indemnity, Orion, London, 2005, p. 11.

${ }^{21}$ Ibid., p. 21.

${ }^{22}$ Ibid., p. 16.

${ }^{23}$ Ibid., p. 16.

${ }^{24}$ Ibid., p. 19.

${ }^{25}$ Ibid., p. 19.

26 E. Bronfen, 'Femme Fatale: Negotiations of tragic Desire', New Literary History, Vol. 35,Winter 2004, pp. 105.

${ }^{27}$ B. Djisktra, 'Domesticating the Vampire: Hollywood and Seminal Economy', Sisters: The Threat of Female Sexuality and the Cult of Manhood, Alfred A. Knopf, New York, 1996, p. 311.

${ }^{28}$ Ibsen, op. cit., p. 94.

${ }^{29}$ Hedda Gabler, Film, British Broadcasting Corporation, UK, 1963.

${ }^{30}$ Ibsen, op. cit., p. 174.

${ }^{31}$ A. Ganz, 'Miracle and Vine Leaves: An Ibsen Play Rewrought', PMLA,Vol. 94, January, 1979.

${ }^{32}$ Double Indemnity, Film, Paramount Pictures, USA, 1944.

${ }^{33}$ Ibid.

34 H.S. Manon, 'Some Like It Cold: Fetishism in Billy Wilder's Double Indemnity', Cinema Journal, Vol. 44, Summer 2005, p. 18.

${ }^{35}$ Weininger, op. cit., p. 293.

\section{Bibliography}

Allen, V.M., ' One Strangling Golden Hair': Dante Gabriel Rossetti's Lady Lilith'. The Art Bulletin. Vol. 66, June 1984, pp. 285-294.

Bronfen, E., 'Femme Fatale: Negotiations of Tragic Desire'. New Literary History. Vol. 35, Winter 2004, pp. 103-116.

Cain, J.M., Double Indemnity. Orion, London, 2005.

Djisktra, B., Evil Sisters: The Threat of Female Sexuality and the Cult of Manhood. Alfred A. Knopf, New York, 1996.

Fritz Wittel, M.D., Freud and His Time. Liveright, New York, 1931. 
Ganz, A., 'Miracle and Vine Leaves: An Ibsen Play Rewrought'. PMLA. Vol. 94, January 1979, pp. 9-21.

Holy Bible: Old and New Testaments. Tophi Books, London, 1994.

Ibsen, H., Hedda Gabler. New York UP, New York, 1955.

Manon, H.S., 'Some Like It Cold: Fetishism in Billy Wilder's Double Indemnity'. Cinema Journal. Vol. 44, Summer 2005, pp. 18-43.

Rossetti, D.G., 'Body's Beauty'. Collected Prose and Poetry. McGann, J. (ed), Yale UP, New Haven, 2003.

Spector, S.J., 'Love, Unity, and Desire in the Poetry of Dante Gabriel Rossetti'. ELH. Vol. 38, September 1971, pp. 432-458.

Ulanov B.A., The Feminine in Jungian Psychology and in Christian Theology. Northwestern UP, Evanston, 1971.

Weininger, O., Sex and Character. Kessinger Publishing, New York, 2007.

Wilde, O., Salome. J. J. Little \& Ives Company, New York, 1935.

Wilder, B., Double Indemnity. 1944.

Burcu Genc is currently a senior student at Bogazici University, Turkey, and aims at an academic career. 


\title{
The Portrayal of the Male Villain in the Broadcast Televisual Text Hollyoaks
}

\author{
Selina E. M. Doran
}

\begin{abstract}
This research project focuses on a drug-rape storyline in the British soap opera Hollyoaks $^{1}$ and discovered themes of gendered roles, revenge, and power inherent in it. The contemporary male villains are serial rapists who regularly drug girls' drinks to 'speed up the process of getting them into bed'. Later on in this storyline two 'female victim-hero protagonists' thereafter murdered. In order to discover audiences' perspectives on the male villains and the victims' deaths, a screening of this storyline was shown to three sets of audiences: young adult males, young adult females, and an older mixed gender group. Focus group discussions followed the screening of the clips. The research findings show that, although the groups, with the exception of the group of young females, find the rapist characters to be villainous, they also believe that the young females who sought revenge were being 'punished' for their actions. This displays an interesting reversal of the notion that 'good defeats evil'.
\end{abstract}

Key Words: Male villains, soap opera, drug-rape, revenge, tragedy, punishment, focus groups.

$$
* * * * *
$$

\section{Introduction}

The British televisual broadcast text Hollyoaks belongs to the soap opera genre. With the exception of cancellations, soap operas possess an infinite lifespan in television meaning that the open-ended narrative of drama never reaches a final climax. $^{3}$ At present, although there is an ever-growing body of research surrounding American soap operas, there is little written about their British counterparts. Moreover, there seems to be no academic literature focusing solely on Hollyoaks, which was part of the rationale for writing this chapter. Its findings are derived from three focus group discussions: each one followed a screening of constructed clips from the Hollyoaks storyline and the researcher facilitated a discussion. The focus groups used for this research were differentiated by the primary variables of age and gender to give the following groups:
A. five females aged eighteen to thirty;
B. five males aged eighteen to thirty;
C. three males and two females aged thirty-one to fifty-five; 
although this gives a rather small sample, limiting the number of participants in each group allowed them to improve the complexity of their opinions.

This chapter adopts the position that its viewers have an active role in reading the Hollyoaks screening, thus following Smythe's argument that: 'audience members act on the program content [emphasis added]'. ${ }^{4}$ Furthermore it is recognised by Morley that: 'He [the hypothetical viewer] is a subject crossed by a number of discourses'. Thus, whilst reading the text, the reader is influenced both by the actual text as well as social factors, such as gender, values, religion and so forth. Consequently, that is why the focus groups were differentiated by the important social factors of age and gender, as they were more likely to influence how the Hollyoaks storyline was 'read' by participants; these research results will be discussed later on in this chapter.

\section{The Drug-Rape Storyline}

The storyline in Hollyoaks forming the basis of this chapter is what Projansky calls a 'rape narrative', which is any representation of rape, whether it is overt, implied, attempted or coercive. ${ }^{6}$ The Hollyoaks rape narrative focuses on two serial rapists: Andrew 'Andy' Holt and Samuel 'Sam' Owen, who regularly 'spike' the drinks of women with the date-rape drug Gamma-Hydroxybutyric acid (otherwise known as GHB) to, as said by Andy, 'speed up the process of getting them into bed'. 'Drug-facilitated sexual assault,' as it is legally known, is said to be a 'double crime' for its victims as the drug leaves them in an 'extreme and prolonged state of helplessness' during the attack and also 'mind-raped' following it as they are unable to remember the rape clearly, if at all. ${ }^{7}$

Although a number of women were drug-raped in the Hollyoaks storyline, this chapter focuses solely on Melanie 'Mel' Burton, who was raped by Andy, and her twin sister Sophie, who, although was not actually penetrated by the other rapist Sam, was drugged to be raped, indecently assaulted by Andy, and believed that she had also been raped by Andy; thus, making her a victim of the rapists' actions too. The two girls then sought revenge on Andy and Sam, meaning that, drawing upon rape-revenge film terminology employed by Clover, it seems appropriate to refer to Mel and Sophie as 'female victim-hero protagonists'. ${ }^{8}$ Later on in the storyline, Mel was able to exact her revenge on Andy in an abandoned fairground warehouse: Andy attempted to rape Sam's sister Nicole but Mel intervened, hitting Andy with a pole and, thereafter, drugging him, tying him to a chair, and threatening him with further violence; in the end, however, Mel decided that sending Andy to jail would be the best form of justice, and she called the police; before they could arrive, however, Andy tried to escape and, in doing so, inadvertently impaled himself on a spike, dying instantly in front of Mel.

The other victim-hero protagonist Sophie adopted a more pragmatic approach to get revenge on the remaining rapist Sam and tricked him into confessing to the police; consequently, he was sentenced to twenty-five years in jail. A few months 
after this, Sam escaped from prison and went into a local pub with the intention of murdering Sophie by setting her on fire; Mel tried to protect her sister from Sam but was killed instantly when Sam dropped his lighter and the pub blew up; Sophie, however, managed to escape from both the pub and Sam but died shortly after from smoke inhalation. It is discovered later on that Sam has also died in the fire; meaning that the Hollyoaks rape narrative has reached its dénouement.

This storyline in Hollyoaks is similar to the rape-revenge films that became popular in the 1970s and 1980s wherein rape was portrayed as a problem that the victim themselves had to solve. ${ }^{9}$ However, due to its tragic dénouement, it could be said that the narrative could be defined more as a 'revenge tragedy'. Speaking of plays in Ancient Greece, Aristotle once said that 'vengeance can provide the mythos of great tragedy because its overturn is negative'. ${ }^{10}$ Moreover, every successful tragic play has consisted of sensationalised drama, more commonly known as 'melodrama'. It could certainly be said that Hollyoaks, being a soap opera which uses the textual device Fiske calls 'excess for hyperbole' to exaggerate and dramatise content, is melodramatic. ${ }^{12}$ The rape narrative in Hollyoaks, with its emphasis on melodrama and revenge, as well as its dénouement for the characters involved, meets the requirements of a revenge tragedy.

\section{Research Findings}

The focus group research findings demonstrated that participants believed Mel and Sophie were being 'punished' for their actions. The strongest examples of this were the young female participants (Group A) who had a theory why the twins were killed off in Hollyoaks:

Louise: Viewers didn't like them. I don't know if it's because they'd been around for so long or because they were so annoying [original emphasis], especially that Mel one.

Ellis: I think it's because they didn't seem like rape victims, people couldn't sympathise with them.

Louise: Possibly. Yeah.

Ellis: They weren't victims, they were stronger than that and they weren't sort of cowering. She [Mel] was saying 'You're disgusting' [to Andy]; the fact that she was even able to do that considering the nature of the rape. It was violent; it was brutal. It wasn't even like he had been a friend and she had the right to confront him.

Leoni: That's true. 
Ellis: Maybe people didn't like the fact that the twins didn't just take it.

This notion of what constitutes a 'rape victim' is prescriptive in nature and relies on stereotypical conceptions surrounding rape and its victims; Mel and Sophie are said to be 'stronger' than what these participants consider to be a 'rape victim' as they 'didn't just take it'. These results could be caused by the essentialist ideology of 'benevolent sexism' which, rooted in biological arguments, details that women are pure and need to be protected meaning that any women that transgresses traditional gender-role expectations are likely to be perceived negatively. ${ }^{13}$

The participants' lack of sympathy for Mel and Sophie and condemnation for their quest for revenge seems to confirm Thompson's idea that: 'The very force of the blood-lust aroused by the pursuit of the villain depends on the antithetical identification with and sympathy for the victim'. ${ }^{14}$ Likewise, the participants' lack of 'blood-lust' for the twins' revenge is also possibly related to their perceptions of Andy and Sam. For example, Ellis yelled 'Oh he's so fit [good-looking]' when she first saw Andy in the screening, rather than feeling he is a figure to be feared or hated. Additionally, the following exchange illustrates that participants did not find Sam to be a villainous character:

Leoni: In the police station, he [Sam] wouldn't have just turned round and said 'You're a bitch' [be]cause she turned him in. I think he'd understand... he is a good guy who went off the rails.

Ellis: Yeah. With him [Sam] he wasn't raping them, he was just kind of giving them the drug and they were up for it...the drug was just kind of loosening them up.

Consequently, Leoni sees Sam as a 'good guy' and Ellis uses euphemisms like 'just kind of giving them the drug and they were up for it' and 'loosening them up' to simplify Sam's actions and, therefore, positions them more as seduction than rape. This could be related to the fact that the participants in this group were regular viewers of the show that watched Sam before he started to drug rape women and perhaps, because of this, could not acknowledge the villainous side of him.

Differing from the previous group, the second focus group (B) consisting of young male participants, seemed to approve of the twins seeking revenge:

Sean: 'Mel's definitely the more empowered character, although the other one was quite strong as well.' 
Grant: Aye, [yes] I would say she [Sophie] is more cunning. Mel was quicker off the mark to start dishing out the abuse, but when it comes to rape you can't really blame her. He [Andy] got off lightly because we like to see him get battered with the pole.

These feelings are possibly related to the young males' feelings on the rapists. For instance, when they were asked their thoughts on the rapists the responses were:

Grant: She [Mel] should have walked up behind him [Andy] and pushed him further up the pole to make sure he was dead.

And

Colin: Disgusting.

Grant: It's probably the worst kind of guy out there.

Sam: I don't think any criminal settings could do justice to what they do, even prison.

Adam: It's where they should bring back the death penalty.

This group's admiration for Mel and Sophie, coupled with their strong feelings against the rapists, mirrors Lehman's theory that watching rape-revenge texts such

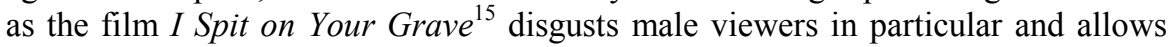
them to further identify with the woman (or in this case women) seeking her revenge. ${ }^{16}$

When asked whether they thought Mel and Sophie 'deserved' to die the responses were:

Sean: I suppose you could say it's full circle, but she didn't commit the first wrong.

And

Adam: She [Mel] got her justice. She got to see her rapist die and then it came back.

Grant: What happened to him [Andy] was very, very deserving [sic]; we actually thought she was too lenient with him. But it always comes down to this nasty wee saying 'two wrongs don't make a right'. Scriptwriters wanted to show, right, this is what'll 
happen if you pursue a wrong or correct a wrong. They're being really, really, really harsh.

These responses confirm that participants believe that Mel and Sophie were being 'punished' for their actions. However, in contrast to the group of young females, participants maintain that this is not the twins' fault, which is emphasised through terms like 'nasty wee saying' and the repetition of the word 'really' when describing how 'harsh' the scriptwriters were being in constructing this ending for Mel and Sophie.

In direct contrast from the first two groups, the final focus group (C) of older male and female participants had a mixed reaction to the twins:

Paul: They were quite smart in what they done [sic]; they both had a plan set up. One said how much she loved him to get him to confess and the other kicked butt [fought back] basically.

Henry: The trick Sophie did is more like a woman would do than a direct attack. It's just how they operate.

Philip: They both had their reasons for what they did and had different personalities, so went about it in different ways. Okay, one was more extreme than the other-

Henry: They'd snapped. Although one was scheming and conniving, she was still acting irrationally to what normal people do.

Consequently, Paul praises the twins for being 'quite smart', and Philip acknowledges that they 'had their reasons' for getting revenge; Henry, on the contrary, uses the words 'scheming' and 'conniving' to describe Sophie's actions, thus portraying her as devious; he also says 'they'd snapped' and were 'acting irrationally', implying that the twins were mentally unstable.

Later on in the focus group, when questioned about their thoughts on the rapists and whether Mel and Sophie were right to seek revenge, the responses were once again mixed:

Paul: I would say that's what the guys deserved for what they did to the two girls.

Elspeth: Yes. Any woman that [rape] happened to...good on them [for getting revenge]...the guys were taking advantage and not giving a damn [caring] about the women. 
Henry: Are any of their revenges justified though? The law is there to do all that.

And

Henry: Their deaths could be retribution or karma. Maybe the message it's portraying [is] that if you do something, it's going to come back to you as well.

Alana: I suppose the more violent of the two died a violent death.

Paul: Yes, one [Sophie] was more like an angel and more loving rather [sic] than the other one [Mel] that burned to death [who] showed more of a violent side.

From this it can be seen that two of the participants think 'good on them' for getting revenge, whereas, in contrast to this, the participant Henry is once again critical of their actions saying that 'the law is there to do all that'. This viewpoint mirrors the notion that 'punishment is a prerogative reserved for those with the requisite authority'. ${ }^{17}$ As a result of this, Henry claims that the twins' deaths might be 'karma' or 'retribution'. Additionally, a link is made by other participants between Mel's aggressive actions and her violent death, which further intensifies the idea that the twins were being punished for their actions, especially Mel.

\section{Discussion}

It can be concluded that the focus groups, with the exception of the group of young females, find Sam and Andy to be villainous characters. Furthermore, the group of young males displayed the strongest negative reaction to the rapists and, because of this, are more admiring of the twins and supportive of their revenge. However, despite different perspectives on the female victim-hero protagonists Mel and Sophie, and whether their revenge was justified, all focus groups come to the conclusion that the deaths of the twins does seem to suggest that they were being 'punished' for seeking revenge. Notably, however, it could be said that the twins did aid in securing legal justice; although Mel acted violently towards Andy and threatened him, in the end she made the decision to send him to jail, and Sophie, similarly, tricked Sam into confessing his rapes to the police; yet, their actions were seen as revenge and, as per the requirements of the revenge tragedy, this resulted in their deaths. It is as Zaibert says: 'Putting a rapist behind bars...is punishment when carried out by State Officials, but mere revenge when it is carried out identically by a group of ordinary citizens'. ${ }^{18}$

This is possibly due to the dichotomy that exists in much literature, and indeed public thinking, between retributive punishment and revenge. The former is said to be set by someone not connected in any way to the victim or the perpetrator thus, 
in theory at least, involves no emotional tone and is henceforth limited in its punishment. Conversely, revenge can be limitless in the harm inflicted to the perpetrator and tends to be done for personal, emotional reasons. ${ }^{19}$ Although this dichotomy is far too reductionist, as it is narrowly-defined and fails to consider extraneous factors, its notions of 'retributive punishment' and 'revenge' finds that the actions of Mel and Sophie in Hollyoaks fit the 'revenge' description better. Moreover, the responses from the focus groups indicate that they too draw upon this punishment-revenge dichotomy, and, following the conventions of a revenge tragedy, that is why Mel and Sophie were murdered for their actions.

\section{Notes}

${ }^{1}$ Hollyoaks, television programme, Lime Pictures, United Kingdom, 1995-present.

${ }^{2}$ Term used in C.J. Clover, Men, Women and Chainsaws: Gender in the Modern Horror Film, British Film Institute, London, 1992, p. 227.

3 J. D'Acci, 'Television, Representation \& Gender' R.C. Hill \& A. Hill (eds), The Television Studies Reader, Routledge, London, p. 254.

${ }^{4}$ D.W. Smythe, 'Reality as Presented by Television', Public Opinion Quarterly, Vol. 18, 1954, pp. 143-156.

${ }^{5}$ D. Morley, Family Television: Cultural Power and Domestic Leisure, Comedia, London, 1986, p. 143.

${ }^{6}$ S. Projansky, Watching Rape: Film and Television in Post-feminist Culture. New York University Press, New York, 2001, p. 18.

7 G. Abarbanel, 'The Victim', Drug-Facilitated Sexual Assault: A Forensic Handbook, M.A. LeBeau \& A. Mozayani (eds), Academic Press, London, San Diego, p. 2.

${ }^{8}$ Clover, op. cit., p. 227.

${ }^{9}$ Ibid., p. 138.

${ }^{10}$ A. Burnett, 'Medea and the Tragedy of Revenge', Classical Philosophy, Vol. 68 (1), 1973, p. 1-24.

11 A.R. Thompson, 'Melodrama and Tragedy', Modern Language Association, Vol. 43(3), 1928, pp. 810-835.

${ }^{12}$ J. Fiske, Television Culture, Routledge, London, 1987, p. 91.

${ }^{13}$ D. Abrams \& G.T. Viki, 'Perceptions of Stranger and Acquaintance Rape: The Role of Benevolent and Hostile Sexism in Victim Blame and Rape Proclivity', Journal of Personality and Social Psychology, Vol. 84 (1), 2003, pp. 111-125.

${ }^{14}$ Thompson, op. cit., p. 822.

${ }^{15}$ I Spit on Your Grave (Day of the Woman), motion picture, Cinemagic, United States, 1978.

16 P. Lehman, 'Don't Blame This on a Girl: Female Rape-Revenge Films', Screening the Male: Exploring Masculinities in Hollywood Cinema, S. Cohan \& I. R. Hark (eds), Routledge, London, New York, 1993, p. 104. 
17 J. Feinberg, Doing and Deserving: Essays in the Theory of Responsibility, Princeton University Press, Princeton, NJ, 1970, p. 71.

${ }^{18}$ L. Zaibert, 'Punishment and Revenge', Law and Philosophy, Vol. 25(1), 2006, pp. 81-118.

${ }^{19}$ R. Nozick, Philosophical Explanations, Clarendon Press, Oxford, 1981, pp. 366367.

\section{Bibliography}

Abarbanel, G., 'The Victim'. Drug-Facilitated Sexual Assault: A Forensic Handbook. LeBeau, M.A. \& Mozayani, A. (eds), Academic Press, London \& San Diego.

Abrams, D. \& Viki, G.T., 'Perceptions of Stranger and Acquaintance Rape: The Role of Benevolent and Hostile Sexism in Victim Blame and Rape Proclivity'. Journal of Personality and Social Psychology. Vol. 84 (1), 2003, pp. 111-125.

Burnett, A. 'Medea and the Tragedy of Revenge'. Classical Philosophy. Vol. 68 (1), 1973, pp. 1-24.

Clover, C.J., Men, Women and Chainsaws: Gender in the Modern Horror Film. London, British Film Institute, 1992.

D'Acci, J., 'Television, Representation \& Gender'. The Television Studies Reader. Hill, R.C. \& Hill, A. (eds), Routledge, London, 2004.

Feinberg, J., Doing and Deserving: Essays in the Theory of Responsibility. Princeton University Press, Princeton, NJ, 1970.

Fiske, J., Television Culture. Routledge, London, 1987.

Lehman, P., 'Don't Blame This on a Girl': Female Rape-Revenge Films'. Screening the Male: Exploring Masculinities in Hollywood Cinema. Cohan, S. \& Hark, I.R. (eds), Routledge, London \& New York, 1993.

Morley, D., Family Television: Cultural Power and Domestic Leisure. Comedia, London, 1986.

Nozick, R., Philosophical Explanations. Clarendon Press, Oxford, 1981. 
Projansky, S., Watching Rape: Film and Television in Post-Feminist Culture. New York University Press, New York, 2001.

Smythe, D.W., 'Reality as Presented by Television'. Public Opinion Quarterly. Vol. 18, 1954, pp. 143-156.

Thompson, A.R., 'Melodrama and Tragedy'. Modern Language Association. Vol. 43(3), 1928, pp. 810-835.

Zaibert, L., 'Punishment and Revenge'. Law and Philosophy. Vol. 25(1), 2006, pp. 81-118.

Selina E. M. Doran is a Doctoral Candidate at the University of Strathclyde in Glasgow. Current doctoral research focuses on how school shooters in the United States use news and electronic media to promote and reshape their identities. Her areas of research interest are gender, television, media, new media, and crime. 


\title{
Monstrous Action-Men and Jealous Princesses: Defining the Villain in Gendered Narratives
}

\author{
Dikmen Yakall-Çamoğlu
}

\begin{abstract}
The aim of this study is to explore how Turkish children relate their own narrative identities to the characters of popular stories and how they place and perceive the villain within this context. The study begins by exploring the representations of 'the villain' in some popular media for children (Disney and Marvel magazines, where we find the intertextual stories to which children are exposed in the form of fairy tales, books, television shows, plays, computer games and feature animations and films). It raises the question whether the popular stories for girls and boys construct two separate narratives of villain. These narratives are compared and contrasted with the stories composed by children through a narrative analysis of the content of semi-structured interviews conducted with 26 children (aged 4-8, from middle-class, Muslim families living in Istanbul). These children were asked to create a story with themselves as the main character. Here, the main assumption is that popular culture addresses men and women differently; by and large, their narratives are constructed with different themes. The representations of villains in popular culture present us with two distinct sets of stereotypical character traits. These suggest that the existence of these distinct stereotypical representations of villainy seems to construct separate infrastructures of emotion and communication for girls and boys as they grow up. On the basis of the interview data, it may be argued that the conflicts created by these distinct types of villain construct the points of view of the two genders in totally distinct ways, which reinforce the patriarchal system: as the boys are trained to fight with monstrous villains to save the world, the girls are made ready to fight with each other over trivial aspects of daily life!
\end{abstract}

Key Words: Gender identity, narrative identity, Turkish children, children's magazines.

$* * * * *$

\section{Introduction}

This chapter presents part of a much more extensive study which examines the relationship between narrative identity, popular culture and heterosexual relationships in Turkey. The representations of villains in popular culture content (both for adults and children) present us with two distinct sets of stereotypical character traits. One set belongs to women's cultural forms, which attribute certain themes and traits to the villain; the other set is for men's cultural forms, which in turn present their distinct traits for the villain. We may argue that the existence of 
these distinct stereotypical representations of villainy seems to construct infrastructures of emotion and communication for girls and boys as they grow up. The aim of this study is to explore how Turkish children relate their own narratives to the characters of popular stories and how they place and perceive the villain within this context.

The study begins by exploring the representations of 'the villain' in some popular media for children. As a start, I have identified stories for girls such as Cinderella, Snow White, Beauty and the Beast, Sleeping Beauty and Disney's version of The Little Mermaid; and, for boys, stories of Marvel characters (such as Hulk, Spider-man, Action-man, X-Men, Iron-Man). These tales, in the comic format in particular, are considered central to the most popular girls' and boys' magazines. However, they are also significant intertextual stories to which children are exposed in the form of fairy tales, books, television shows, plays, computer games and feature animations and films. Thus, with every different form, the children's familiarity with the characters and the stories increases.

After a thematic analysis of more than 40 issues of Prenses and Marvel Süper Macera magazines (published between 2006-2010), these narratives are compared and contrasted with the stories composed by children through a narrative analysis of semi-structured interviews conducted with 26 children (aged 4-8; from middleclass, Muslim families living in Istanbul). However, because of space constraints, only the data of the elder group (13 children aged 7-8) will be used in this chapter. The children were asked questions about the forms of popular culture that they consumed and were then each asked to create a story in which they were the main character.

The theoretical background of this study is the narrative construction of culture and narrative identity. Here, narratives are considered as a way of mediating in the construction of meaning.

In today's culture, it is through thinking of ourselves autobiographically and by way of telling our life stories to others that we can 'integrate the past, present and future and thereby constitute stable, coherent identities on both a personal and communal level'. ' Only with this story can we convey ourselves to others and act as if there was a consistent, stable self. ${ }^{2}$ Narratives give life a feeling of order and events have no meaning in themselves unless we confer it on them with our stories. $^{3}$

It is the common stories and story forms which help us to find a meaning for different happenings. These stories change as we move from one stage to another, hand in hand with social and cultural transformations. Thus, this study assumes that because, starting in childhood, we locate ourselves or are located within a repertoire of prototypical emplotted stories, ${ }^{4}$ these narratives become the basis of our narrative identities. The way in which we represent our stories becomes our reality. This study, then, assumes that the forms of popular culture, in particular when they present the same themes intertextually, introduce children to the limited 
options of their emplotted stories and the tales in question, their structure and characters become the prototypes for children to build their own narratives on.

Villainy, for this study, is 'evil' put into the format of a story. A real person cannot be a villain unless $\mathrm{s} /$ he becomes a character in a narrative. Villainy is a narrative identity, which, unlike our own narrative identities, is not created or narrated by the villain herself, but by the protagonist, or in relation or opposition to her. In other words, creating a villain is about positioning a character - with the emphasis on evil - within the structure of a narrative. From this aspect, the villain is much more than a character that opposes the hero or a criminal; $\mathrm{s} / \mathrm{he}$ is the very maker, the plotter of the story.

By patriarchy, I refer to the kind of system of social organisation 'based on hierarchy and the struggle to accumulate power mainly by means of coercion. ${ }^{5}$ As Sarah Martin points out, this is the system which has always dominated the world and that the villain lies at its core, as the embodiment of the excessive abuse of power. In passing it should be noted that, as the voices of the feminists become dominant in social narratives, the ways of patriarchy become even more subtle and canny.

\section{The Popular Culture Content}

The recurrent categories that can be derived from the stories in the girls' magazine are: goodness, self-sacrifice, body, beauty, dressing/clothing, love, marriage, anniversary, jewels (riches), friendship, dancing, parties, romantic acts, jealousy and magic/fairies.

Antagonism mostly appears either because of natural forces (such as rain, storm or about animals) or because of other females (step sisters, step mothers, other envious women). Another recurrent force of antagonism is the boredom of the heroine and the plot of the story is built on her search for some amusement. There is hardly a male enemy in the narratives. Except for Ursula, who is the villain of The Little Mermaid, antagonism towards the protagonist is personal, mostly because of jealousy, as in Snow White and Cinderella. In Sleeping Beauty, Maleficient is the embodiment of wickedness and the ultimate nemesis - but she feels all her brutal rage because she was not invited to the christening party of Aurora, the little Princess. She curses the little child and tries to destroy her for years to come only because she herself was forgotten.

Ursula's villainy, in contrast, comes from wanting to rule Atlantica by getting rid of Ariel's father. However, her plans to seize power form around Ariel's forbidden love for the human Prince Eric. Once more things get personal.

In the original story Snow White's evil step-mother orders her death because she cannot bear the fact that the girl is more beautiful. Snow White is saved from death when the huntsman lets Snow White go, telling her to flee and hide from the Queen. He then brings the queen the heart of a young deer, which is prepared by the cook and eaten by the queen. However, in the magazines, the evil queen does 
not appear at all and life for Snow White and the handsome prince seems to be full of long walks and picnics in the forest.

In the boys' magazines, in contrast, the recurring categories in the stories are fighting, personal strength, special power/weakness, scientific innovations, technology, weapons, danger, saving the world, keeping secrets, villainy and transformation. Unlike the apparent triviality of everyday life in the girls' stories, life appears to be altogether more portentous in the boys' magazines. In these stories what is at stake is the principle of order in society and responsibility of the hero to negotiate power for this order.

In these, superheroes and super villains resemble each other in their powers, abilities and origins. In some cases, the only difference between the two is that the hero uses his extraordinary powers to help others, while the villain uses his powers for selfish, destructive purposes. Antagonism is not personal as it is in the counterparts for girls; most often the villains have ambitious, greedy goals to reach and the superheroes stand in the way of the villains. And sometimes the villain is simply so evil that he seeks to prevent the hero from doing 'good' to others.

Although the 'badness' of a character is understood by his eagerness to harm others, time and time again the heroes have to harm innocent people on the way towards 'the final good cause'. Sometimes the predicament is even more complicated, and, unlike girls, boys are led to think about it. For example, in one of the stories of X-Men in Marvel Super Macera, Magneto, the mutant says,

This planet is older than 5 billion years. However, in the last two hundred years, human beings harmed it so much that it can survive no more than ten years. They invented wars and torture. All the relatives I once had were either killed in gas rooms or burnt in periodically performed genocides. Humankind was created as flawed from the very beginning and we have to recreate them as soon as we can. As a more intelligent ethnic group, maybe this is our moral responsibility. ${ }^{6}$

Although there are studies, which argue that children need the binary oppositions of 'good/evil' and 'right/wrong' in order to make sense of the world, ${ }^{7}$ the post-structuralist view finds its way into these narratives, insisting that the layers of meaning are woven into and around each other and that nothing is unequivocal or absolute. As we can see here, villainy becomes only a matter of positioning. Just as God appears to be the ultimate hero in the Flood Story, even though and because he harms human beings for the final good cause, here the villain sees himself lined up for the same kind of 'godly' job. Most of the time, rather than the relativity of goodness and badness, what we should focus on is the narrativity and the position-bound nature of villainy and heroism. Although human beings are intrinsically obsessed with 'goodness', because goodness is socially 
constructed, and because the same kind of patriarchal violence is at the core of both heroism and villainy, it is generally impossible to differentiate a hero from a villain unless the narrative suggests so. Patriarchal society may justify evil (e.g. harming others) as 'good' and 'morally responsible' within a narrative. In such a society, this makes males ready to join in actions for 'good' ends, when and if a social narrative justifies it.

There are obviously more villains than heroes in boys' magazines because every hero has his own villains who are gifted with special, monstrous powers. They are in sophisticated shapes and costumes and may originate from other worlds. For example apart from his most infamous and dangerous enemies, such as Green Goblin, Dr. Octopus and Venom, Spider Man has more than 15 villains. As with the hero, most of the powers of these villains result from scientific accidents or the misuse of technology. Most villains are male and have animal-themed costumes and powers.

\section{The Interviews}

The stories of the children conform to the narratives in the popular culture. The forces of antagonism in the girls' stories were more diversified than those in the boys' stories but they were always on the personal level. In Lara's (7) story, antagonism stemmed out of sickness. In her story, Lara was a princess who fights the sickness of her queen mother by giving her some pills. She was also looking after her sisters. Ayşe (8) was a cat with a golden heart that helps those in need. Thus she was fighting with the misfortunes (e.g. poverty) of the others. Demet (8) becomes Bella in her story: 'the Beast tries to get hold of and kidnap Bella by force. I try to resist him but because he is a strong beast, I am imprisoned in the Castle. Then we spend some 'good' times together.' The hostile force at the beginning of the story turns out to be the love of her life. Su (7) tells the story of a princess who loses the key to her violin case; Derin (8), in her narrative, focuses on jealousy between the females and 'winning' the love of the popular male. At a dance party, with the help of a magic bracelet, she gets to dance with the man she loves. Ece (7) also wanted to tell her own story as a princess. She touched on nearly all the categories in a single narrative: 'There would be a fairy and her twin. There would also be a witch who is bad. I am very beautiful and rich as a princess and I have many friends and a thousand cousins... and a handsome prince' Although there is a 'bad' witch, it is not clear how she harms others; in Ezgi's (7.5) story the antagonist force was boredom and she had to try to find a cure for it.

In their self-narratives, the boys are saving their country or the world. When I asked them to narrate a story with themselves in it, the boys created stories in which the central themes were war and fighting. However, when asked why the world or their country was in danger, they could not answer properly. For example, Kerim (8) said, 'I don't know' with a gesture as if my question was completely irrelevant to the story. Later on, he said that the villains came from outer space and 
that they are really bad. He wanted to transform himself into Four Arms (a hero from Ben 10) and defeat them, saving the world. Deniz (8) told a story about a big rocket which was turned towards Turkey and said that he would send it back with a shield so that it would shoot the aliens instead. In this story, he was very brave, with the ability to jump very high. He used a laser, string and a rocket launcher to fight the enemy. 'Power' in the boys' narratives was not in 'little things' or negotiated, as it was in the girls' stories. It was more oppressive.

Doğu (8) wanted to be Spider-man. He would fight and kill the enemy (X-men) by throwing his net. Emir (7) told the story of Megas, who kills the villains, monstrous aliens, with the cooperation of the other good people. Atlas (7) wanted to be Ben 10 and would press the watch and fight the villains (once again, villains are an empty category; he could not tell who they were). Tolga (7) wanted to be Spider-man; he told how he jumped into a house and fought the villains who destroyed houses and cars.

\section{Concluding Remarks}

If we go back to the beginning, and consider the concept of narrative identity and the villain as the maker of our stories, we may argue that the existence of such diverse forces of antagonism in the genres for the two sexes constructs an infrastructure of emotion and communication for both boys and girls. Nearly every boy's story in this study has at least one clear-cut male villain with whom they have to fight. However, the antagonisms in the girls' stories give them the feelings of resentment, jealousy and the possibility of doing good. The boys' stories, in contrast, give them responsibilities on a cosmic scale.

The existence of these villains creates two different worlds. In one of them there is always a threat of destruction; in the other one, things are personal and the society and its life style is barely under threat. In the boys' world there is a risk of the discontinuity of order, whereas the girls' world is continuous and even monotonous, without a hint of change. All these themes in the intertextual forms fashion the heroes of the future in a certain way with distinct characteristics depending on the targeted gender. However, in the end the patriarchal order is reinforced. If we consider the stories of girls, it may be argued that our patriarchal society constructs women as mutual enemies. But men are brought up to be ready to engage in war with any socially constructed villain so long as his enmity is justified in a narrative.

\section{Notes}

${ }^{1}$ L.P. Hinchman \& S.K. Hinchman, Memory, Identity, Community: The Idea of Narrative in the Human Sciences, State University of New York, New York, 2001, p. 2. 
2 P. Ricoeur, 'Life in Quest of Narrative', On Paul Ricoeur: Narrative and Interpretation, D. Wood (ed), Routledge, New York, 1991; P. Ricoeur, 'Narrative Identity', On Paul Ricoeur: Narrative and Interpretation, op. cit.

3 See L. Mink, 'Narrative Form as a Cognitive Instrument', Historical Understanding, F. Brian, O.E. Golub \& R.T. Vann (eds), Cornell University Press, Ithaca, 1987; also see, H. White, 'The Value of Narrativity in the Representation of Reality', On Narrative, W.J. Mitchell (ed), The University of Chicago Press, Chicago, 1981.

${ }^{4}$ Hinchman \& Hinchman, op. cit., p. xxiii; M.R. Somers, 'The Narrative Constitution of Identity', Theory and Society: Renewal and Critique in Social Theory, Vol. 23, No. 5, 1994, p. 614.

5 S. Martin, 'The Romantic, Silent Villain: The Minimalist Construction of Patriarchal Villainy in John Le Carré's Karla Trilogy', Paper presented in the 1st Global Villains and Villainy Conference, by Inter-Disciplinary.Net, Mansfield College, Oxford, 2009.

${ }^{6}$ Marvel Süper Macera, 2007, pp. 11-14.

7 B. Davies, 'Constructing and Deconstructing Masculinities through Critical Literacy’, Gender and Education, Vol. 9, 1997, pp. 9-30.

\section{Bibliography}

Baudrillard, J., Simulacra and Simulation. The University of Michigan Press, Ann Arbor, 2006.

Carr, D., 'Narrative and the Real Worlds: An Argument for Continuity'. Memory, Identity, Community: The Idea of Narrative in the Human Sciences, Hinchman, L.P. \& Hinchman, S.K. (eds), State University of New York, New York, 2001.

Davies, B., 'Constructing and Deconstructing Masculinities through Critical Literacy’. Gender and Education. Vol. 9, 1997, pp. 9-30.

Davies, B., 'The Discursive Production of Male/Female Dualism in School Settings'. Oxford Review of Education. Vol. 15, No. 3, 1989, pp. 229-241.

Ezzy, D., 'Theorizing Narrative Identity: Symbolic Interactionism and Hermeneutics'. Sociological Quarterly. Vol. 39, No. 2, 1998, pp. 239-253.

Freeman, M., 'From Substance to Story: Narrative Identity and the Reconstruction of the Self'. Narrative and Identity. Brockmeier, J. \& Carbaugh, D. (eds), Johns Benjamin Publishing Company, Amsterdam/Philadelphia, 2001. 
Gergen, M., 'Life Stories: Pieces of a Dream'. Social Construction: A Reader. Gergen, M. \& Gergen, K. (eds), Sage, London, 2003.

Hinchman, L.P. \& Hinchman, S.K. (eds), Memory, Identity, Community: The Idea of Narrative in the Human Sciences. State University of New York, New York, 2001.

Inness, S.A. 'It's a Girl Thing: Tough Female Action Figures in the Toy Store'. Action Chicks: New Images of Tough Women in Popular Culture. Inness, S.A. (ed.) Palgrave Macmillan, New York, 2004.

Kline, S. Out of the Garden: Toys, TV and Children's Culture in the Age of Marketing. Verso, London, 1993.

Marsh, J., 'But I Want to Fly, Too' Girls Add Superhero Play in the Infant Classroom'. Gender and Education. Vol. 12, No. 2, 2000, pp. 209-220.

Martin, S., 'The Romantic, Silent Villain: The Minimalist Construction of Patriarchal Villainy in John Le Carré's Karla Trilogy'. Paper presented in the 1st Global Villains and Villainy Conference, Inter-Disciplinary.Net, Mansfield College, Oxford, 2009.

Mink, L.O., 'Narrative Form as a Cognitive Instrument'. Historical Understanding. Fay, B., Golub, E.O. \& Vann, R.T. (eds), Cornell University Press, Ithaca, 1987.

Ricoeur, P., 'Life in Quest of Narrative'. On Paul Ricoeur: Narrative and Interpretation. Wood, D. (ed), Routledge, New York,1991.

—, 'Narrative Identity'. On Paul Ricoeur: Narrative and Interpretation. Wood, D. (ed), Routledge, New York,1991.

Somers, M.R., 'The Narrative Constitution of Identity'. Theory and Society: Renewal and Critique in Social Theory. Vol. 23, No. 5, 1994, pp. 605-649.

White, H. 'The Value of Narrativity in the Representation of Reality'. On Narrative. Mitchell, W.J. (ed), The University of Chicago Press, Chicago, 1981.

Wohlwend, K.E., 'Damsels in Discourse: Girls Consuming and Producing Identity Texts through Disney Princess Play'. Reading Research Quarterly. Vol. 44, No. 1, 2009 , pp. 57-83. 
Dikmen Yakalı-Çamoğlu received her $\mathrm{PhD}$ in cultural studies from the University of Birmingham, UK. She is currently an assistant professor at Doğuş University, Istanbul. She teaches courses on communication theories, cultural theory and popular culture. Her current research and writing interest is construction of narrative identities in and through popular culture. 



\section{PART V}

\section{Villains of Our Youth}





\title{
The Triumvirate of Evil: The Major Villains in Don Rosa's Donald Duck Comics
}

\author{
Katja Kontturi
}

\begin{abstract}
As a successor of Carl Barks, the creator of the numerous characters in the Duck universe, Don Rosa follows Barks' example in many ways when writing and drawing comics, including his depiction of the Triumvirate of Evil, the three biggest villains in the Duckburg. In this chapter, I will present Don Rosa's view of Duckburg's major villains: The Beagle Boys, Magica DeSpell and Flintheart Glomgold. How do these three differ from one another? What is their main goal in life? How have they become villains in the Duck universe, or more specifically, what made them enemies of Scrooge McDuck? The Beagle Boys are a bunch of old time robbers, who want easy money. As Rosa says, they are 'lovable goofs': they would never want to hurt Scrooge, they just want to rob his fortune. Perhaps they even like him in secret. Magica the Spell is an Italian witch, or sorceress, as she always remembers to point out. She lives on the mountainside of the volcano Vesuvius in Sicily and, as her name suggests, she is quite a fantastic character. Her main goal in life is to steal Scrooge's first dime. She needs it for an ancient spell: by melting the dime in a specific way she would gain the Touch of Midas. As for the final one, Flintheart Glomgold, he is the major villain. He lives in the Valley of Limpopo in South Africa and he has gotten all his fortune by stealing, cheating and by various other dishonest means. He doesn't want anything from Scrooge - he only wishes that Scrooge suffers and dies in the most painful way possible. The Triumvirate of Evil consists of three different types of villains. They all have different goals, but yet they all share the same enemy: Scrooge McDuck.
\end{abstract}

Key Words: Comic, Disney, Donald Duck, Don Rosa, sorceress, villain, witch.

$* * * * *$

\section{Introduction}

Don Rosa (1951- ), an American comic artist and writer, is one of the biggest names in the field of Disney and especially Donald Duck comics at the moment. Rosa is well known across the Europe above all of his collection of Life and Times of Scrooge McDuck of which he received a Will Eisner award ${ }^{1}$ on 1995.

In this chapter, I will concentrate on the three major villains Rosa uses regularly in his comics: the Beagle Boys, Magica DeSpell and Flintheart Glomgold. All these characters have been created by Carl Barks (1901-2000), a world known comic artist whose most famous character creation is Scrooge McDuck himself. Don Rosa regards Barks as his role model and follows his work in various ways: he refers to the stories Barks wrote, writes sequels to them and, 
above all, continues the history of the ducks as well as makes a point to depict the characters and their personalities the same way Barks did.

Duckburg's Triumvirate of Evil, as Rosa calls them, consists of the Beagle Boys, a group of old-time burglars, Magica DeSpell, an Italian witch, and Flintheart Glomgold, a millionaire from South Africa. All these consider Scrooge McDuck their major enemy, but as I'm pointing out in this chapter, they relate to Scrooge and his fortune in very different ways. Eventually, I will also discuss whether or not there really is an evil villain in the Duck comics.

\section{The Beagle Boys}

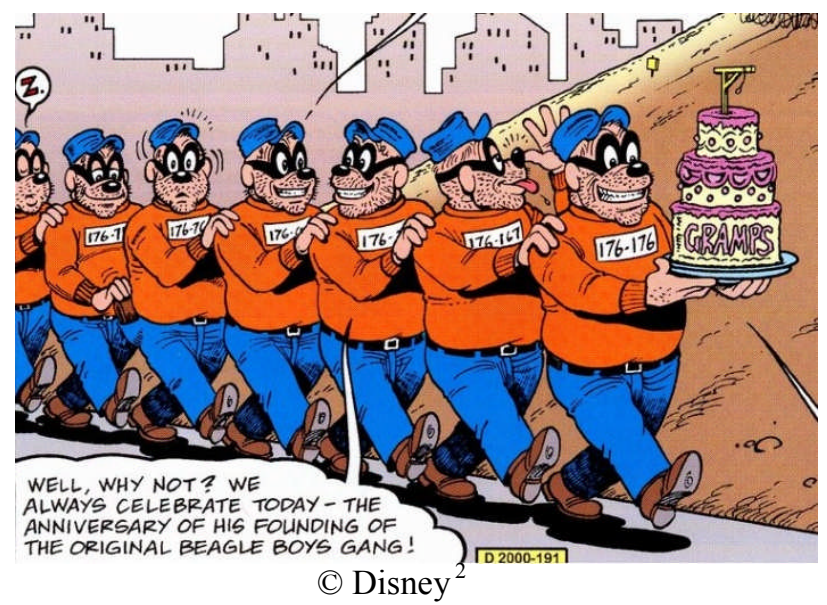

The Beagle Boys are a bunch of old time robbers and burglars. Their main goal in life is to be rich in the easiest way possible, which of course means that they wish to steal Scrooge McDuck's fortune. Scrooge first met the Beagle Boys in his youth as he was sailing the Mississippi River. Their father, Blackheart Beagle ${ }^{3}$ is the grandfather of today's Beagle Boys, of which some are brothers and some cousins. ${ }^{4}$

All of the Beagle Boys look alike and the only difference between their appearances is the prison numbers they have on their uniforms. These numbers are combinations of the different variations of 1, 6 and 7. All in all, you can say that the Beagle Boys are one person divided into seven different characters ${ }^{5}$ as one can't really tell the difference between their personalities. There's only one exception: one Beagle Boy has grown fond of prunes. ${ }^{6}$

The Beagle Boys are not the sharpest pencils in the box. A good example on proving that statement is Rosa's comic The Beagle Boys vs. the Money Bin (2001). In that story, the Beagle Boys manage to break into Scrooge's money bin when 
he's not home. But, simple as they are, the whole group is being caught by the bin itself: one of them gets stuck between the bookshelves in the library; the other one can't fit himself back to the air duct because he has eaten too many prunes and so forth. ${ }^{7}$ Hence their stupidity the money is saved.

As the Beagle Boys aren't too intelligent, they tend to rely on the means someone else has invented. There are several times when have stolen an object or a device from the inventor Gyro Gearloose, and used that machine as a way to steal the money. An example is a contraption that is meant to 'help psychiatrists to examine the dreams of their patients! The wearer of such a brain-scanner can mentally enter into the dreams of the subject!' The quite genius idea for the Beagle Boys to enter Scrooge's dream is that whatever Scrooge thinks at that moment, is the dream itself. So when the burglars ask the combination of the lock of the vault, Scrooge automatically thinks of it - and speaks it aloud in his dream. ${ }^{8}$

Even though the Beagle Boys have the wits to use these methods, they lack the intelligence to realise that at the same time the ducks can use these stolen devices against them. The Beagle Boys tend to be over-confident with the use of the new technology even though they do not know its full potential. Concerning this example I provided, the Beagle Boys failed of course in the end, as Donald came to Scrooge's help and found a way to beat the Beagles.

As Rosa points out in his short article about the Triumvirate of evil, the Beagle Boys have a special kind of relationship with Scrooge McDuck. Rosa says that the Beagle Boys might even like Scrooge - in secret, of course. ${ }^{9}$ If we look at each story that includes the Beagle Boys as the main villains, ${ }^{10}$ we notice that there isn't a single case when the Beagle Boys would have threatened Scrooge and the other ducks with guns or serious violence. In Cash Flow (1987) they use guns, but those are special weapons designed to both neutralize the friction of the surface and negate the moving mass's inertia. ${ }^{11}$ In this case, using these 'guns' didn't cause a mortal danger to any of the characters.

So the Beagle Boys definitely do not want to harm Scrooge. One could almost say that they share a certain love-hate relationship. One must also remember that it was the attack of the Beagle Boys, which pumped new energy to Scrooge when he felt really old and tired and thought he had done everything he possibly could in Rosa's story The Richest Duck in the World (1994). Defending his fortune once again since his youth against these villains alongside with his nephew and grandnephews showed Scrooge that there is still strength in him. ${ }^{12}$ Hence the Beagle Boys have a very important role in Scrooge's life as opponents who give him every reason to be alert even in his old days. 


\section{Magica DeSpell}

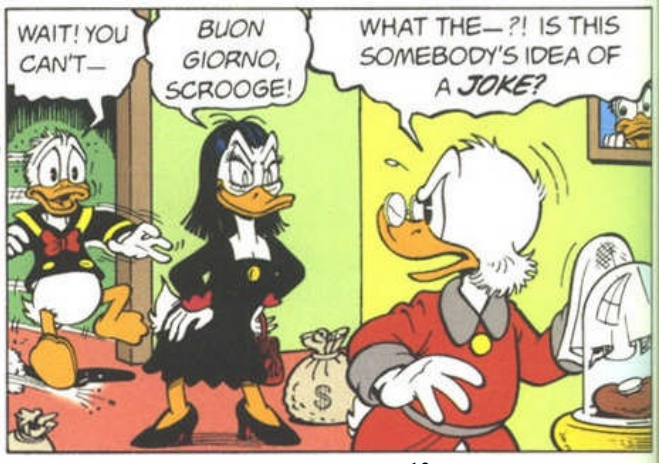

(C) Disney ${ }^{13}$

Magica DeSpell is an Italian witch or a sorceress as she remembers to point out. ${ }^{14}$ She lives on the mountainside of the volcano Vesuvius in Sicily. Magica isn't magical character by natural, but she uses magic as a tool to get what she wants, which is the first dime Scrooge has ever earned. She needs especially the first coin of the richest man in the world for a spell, created by the famous witch Circe, ${ }^{15}$ to cast the dime into a medallion. With that medallion, she would get the Touch of Midas and would be able to turn anything into gold. ${ }^{16}$

For a duck woman, Magica has unusual black hair, she wears makeup and her black dress has a quite revealing cleavage. She could easily be mistaken as a femme fatale, but in Don Rosa's comics Magica never uses her looks to get what she wants. She can change her appearance with the use of magic, ${ }^{17}$ but she never tries to lure her way into Scrooge's bin by simply looking gorgeous. She considers herself to be above that sort of behaviour.

Magica's ordinary magical tool is a wand. She has had several magical wands each of which has a different kind of effect. For example in a comic, A Matter of Some Gravity (1996), Magica uses a wand, which can alter the gravity. By saying the special magic words 'Gravitatus horizontus', the wand casts a spell on Scrooge and Donald and thus changes their gravity to horizontal. Everything else remains as it was; only Scrooge and Donald are literally walking on walls. ${ }^{18}$

What is special about this wand is that you don't need to be a witch or a sorcerer to use it. One must only have the wand in the hand and know the magic words to cast a spell, which can be seen when Scrooge steals the wand and uses it to change their gravity back to normal. ${ }^{19}$ This also proves that Magica's abilities are not natural but they lie strongly on the tools she uses.

If we look at the means Magica uses more closely, we notice the same thing as with the Beagle Boys. All those means, by which Magica tries to rob the first dime, are not in any way a real threat to Scrooge's health. Her spells are used to create 
Scrooge some sort of a disability, which would open an opportunity for Magica to take the dime unstopped, as she seems to avoid open confrontations with Scrooge. She is also intelligent enough to reason with - there are cases when Scrooge has come forward to make a deal with her to benefit them both.

In A Little Something Special the whole Triumvirate has combined their strength and the Beagle Boys have managed to empty Scrooge's money bin. Magica has the first dime in her hands, but Scrooge tells her the agonizing truth: he is now poor. All the money from the bin is gone, so the spell will no longer work either. It is not shown in the comic, but they clearly make a deal: apparently she gives the dime back (Scrooge is seen later on to have it in his hands) and he gives her an advice. Later in the story, Magica mentions about the idea that Scrooge gave her, and takes the Beagle Boys with her to the bin of Flintheart Glomgold - to steal his fortune! $!^{20}$

So it looks like Scrooge and Magica share some sort of respect towards each other. Both of them are determined and smart, and there are times Scrooge would not be able to handle her wits by himself. Magica has her own moral code: it is alright to steal one coin, but she would not hurt anyone by trying it. And if the situation seems hopeless, she backs off and tries again later.

\section{Flintheart Glomgold}

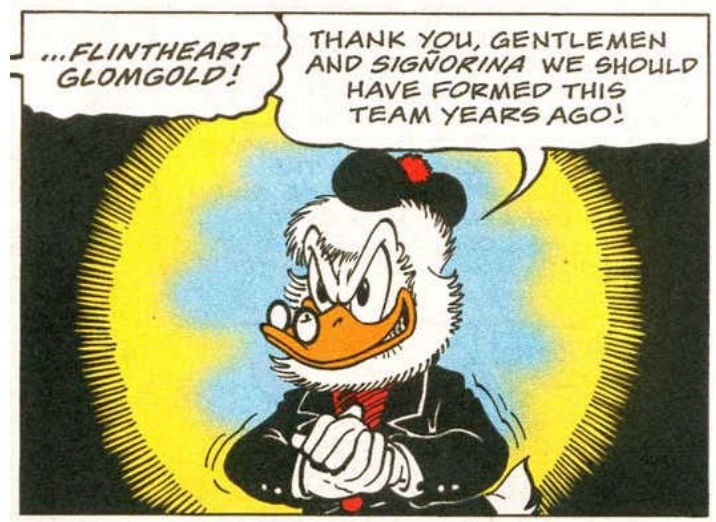

(C) Disney ${ }^{21}$

Flintheart Glomgold is a Dutch-born Afrikaner millionaire living in the valley of Limpopo, South Africa. As his name suggests, he is not the most honest person around. 'Glom' is American slang for 'to steal', so his name could also be 'Goldstealer'. Flintheart has gathered quite a fortune like Scrooge, but the biggest difference between them is that Flintheart has not done so by any honest work. He has stolen, cheated, plotted and used any means necessary to make money. He does not care whether the means necessary are illegal or not. 
Scrooge first met Flintheart in his youth in South Africa in a story The Terror of the Transvaal (1993). Flintheart is first shown to the readers as a young fellow trying to steal the diamonds other people have dug. His name is not revealed until the end of the comic, but his character and personality will become clear quickly for everyone as the story unfolds. At first, after his unsuccessful stealing attempt and being tied up on a water buffalo Flintheart is freed by Scrooge, whose generosity he repays by stealing all of his possessions and brags about it in the saloon in a town nearby. He even claims it was Scrooge who did all the stuff he did himself. ${ }^{22}$

After Flintheart's treachery, Scrooge tracks him down and gives him the 'syrup and feathers' -treatment and puts him to jail. This first meeting gives a start to lifelong hostilities between these two characters. ${ }^{23}$

Flintheart isn't afraid to use life-threatening methods or put ducks in mortal danger to get what he wants. He has used different weapons, kidnapped the nephews and even dropped a huge rock on the road ducks were driving in attempt to crush their vehicle. ${ }^{24}$ The grudge against Scrooge that rose after he humiliated Flintheart in their youth, is so big that Flintheart isn't ever going to forgive him. As the Beagle Boys and Magica DeSpell just want something Scrooge possesses, Flintheart wants to see Scrooge dead. He wants him to die in the most painful way ever, suffering and making him the richest man in the world. ${ }^{25}$

Magica Scrooge could make deals with. But attempting the same thing with Flintheart, the result is treachery, as happened in Return to Plain Awful, when Scrooge was left as a prisoner in the valley and the ducks needed Flintheart's helicopter to fly them away to get the awfultonians what they wanted and set Scrooge free. Flintheart promised to help with his 'word of honor' but deceived them later for his own advantage. ${ }^{26}$

Flintheart Glomgold can be described as the real arch enemy, an 'evil twin' of Scrooge McDuck: they're both wealthy old men who have quite similar appearances. They share a long term 'relationship', which is based on mistrust and disrespect. Flintheart has gathered his fortune by dishonest means and Scrooge always remembers to emphasise that he's made his money fair and square. ${ }^{27}$ That is why Scrooge despises Flintheart and Flintheart bares the grudge against Scrooge and the situation isn't ever going to change. 


\section{Conclusions}

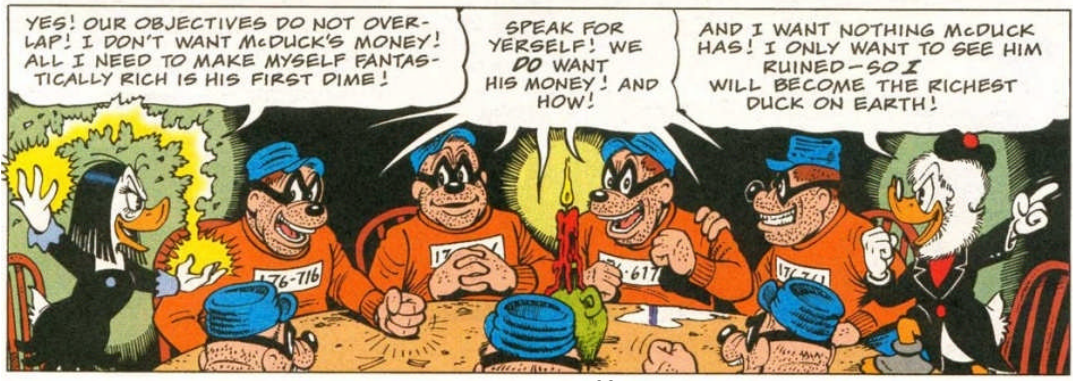

(C) Disney ${ }^{28}$

In this chapter, I have presented the Don Rosa's Triumvirate of Evil. It consists of the three most used villains in Rosa's Disney comics: a robber gang called The Beagle Boys, a Sicilian sorceress Magica DeSpell and an Afrikaner millionaire Flintheart Glomgold; each of which are enemies of Scrooge McDuck, but for different reasons. In the introduction, I noted that I would discuss whether there is a real evil character in Don Rosa's Disney comics. As Disney usually tends to dress up old fairy tales into much nicer and kinder stories, it was interesting to see whether Rosa would follow that example. Is there an evil character hiding in the Triumvirate of Evil?

The Beagle Boys just want money, but they want it fast. So who else would be a better target than the world's richest duck? As simple as they are, the Beagle Boys have their own moral code, so they would not even think of harming Scrooge or the other ducks.

Magica DeSpell shares the same moral code as the Beagle Boys when it comes to harming living beings. She considers Scrooge a worthy opponent: no harm should happen to him or his possessions. If Scrooge would get hurt or lost his fortune, he would not be the richest duck anymore and the spell of Circe would not work.

Flintheart Glomgold is a whole other type of character. He does not care for Scrooge's money; he just wishes Scrooge would die. He bares such a grudge against him that time cannot heal it. Flintheart is the only of these three villains who is capable of putting other people in mortal danger just to get what he wants. He has no moral code; he makes his own codes and lives by them.

As I have now pointed out, Rosa does show that there really is a real evil villain and it is not doubt Flintheart Glomgold. In the first duck comic Rosa ever did, The Son of the Sun (1987), Flintheart hijacks the airplane ducks are travelling in, threatens them with the gun and leaves them flying unpiloted. ${ }^{29}$ This tells the 
reader that we're dealing with an opportunist, who has been one by nature for his life. Scrooge didn't turn Flintheart evil, he was one already.

Although all of these villains are different and want different things, there is cohesion: the members of the Triumvirate of Evil complete each other. Together they form a tight package of villains for a writer to choose from. With this variety, the reader surely will not get bored easily. There are times when we wish to see the simpler Beagle Boys getting stuck in the ventilation ducts of the money bin, and times when we love to see a clever sorceress trying to outsmart Scrooge with one of her magic wands. And there are times when we want to see once again, how Scrooge, the good guy wins over the bad guy Flintheart, and gets the final word.

\section{Notes}

${ }^{1}$ The award is practically 'a comic book academy award'; it is given for creative achievement in American comic books. It is named after a famous comic artist Will Eisner.

2 D. Rosa, The Beagle Boys vs. the Money Bin, published in Uncle Scrooge 325, Gemstone Publishing, Timonium, Maryland, 2004, extract from the first frame, p. 3.

${ }^{3}$ Blackheart Beagle is the real 'brains' of the group. He is the only one of the Beagle Boys capable of really confronting Scrooge in a challenging way. Check out for example A Little Something Special, 1997.

${ }^{4}$ D. Rosa, The Master of the Mississippi, 1992.

${ }^{5}$ There is some sort of disagreement on how many Beagle Boys there actually are. Rosa uses regularly seven of them, but for instance in the TV cartoon Ducktales; there were four Beagle Boys with distinctive features like their height and different personalities. But as I'm studying solely Rosa's comics, I claim that there is seven of Beagle Boys.

${ }^{6}$ As it seen among others in D. Rosa, Cash Flow, 1987, p. 6.

${ }^{7}$ D. Rosa, The Beagle Boys vs the Money Bin, 2001, pp. 11, 14.

${ }^{8}$ D. Rosa, The Dream of a Lifetime, 2002, p. 2.

${ }^{9}$ D. Rosa, 'Pahikset', http://www.perunamaa.net/donrosa/artikkelit pahikset.htm.

${ }^{10}$ These stories are: Cash Flow (1987), His Majesty, McDuck (1989), On Stolen Time (1991), The Master of Mississippi (1992), The Richest Duck in the World (1994), The Duck Who Never Was (1994), The Incredible Shrinking Tightwad (1995), A Little Something Special (1997), An Eye for Detail (1997), The Coin (1999), The Beagle Boys vs the Money Bin (2001), The Dream of a Lifetime (2002) and Trash or Treasure (2003).

${ }^{11}$ D. Rosa, Cash Flow, 1987, p. 7.

${ }^{12}$ D. Rosa, The Richest Duck in the World, 1994, p. 17.

${ }^{13}$ D. Rosa, A Matter of Some Gravity, published in Walt Disney's Comics and Stories 610, Gladstone Publishing, Arizona, 1997, frame 6 on p. 53. 
${ }^{14}$ D. Rosa, A Little Something Special 1997, p.7.

${ }^{15}$ A mythical witch from The Odyssey.

${ }^{16}$ D. Rosa, 'Why does Magica DeSpell want Scrooge's Dime?', http://www. perunamaa.net/donrosa/articles magica.shtml.

${ }^{17}$ For example in story Of Ducks, Dimes and Destinies, (1995).

${ }^{18}$ D. Rosa, A Matter of Some Gravity, 1996, pp. 2-3.

${ }^{19}$ D. Rosa, A Matter of Some Gravity, 1996, p. 15.

${ }^{20}$ D. Rosa, A Little Something Special, 1997, pp 19 \& 26-27.

${ }^{21}$ D. Rosa, A Little Something Special, published in Adventurous Uncle Scrooge McDuck 2, Gladstone Publishing, Arizona, 1998, frame 7 on the p. 10.

${ }^{22}$ D. Rosa, The Terror of the Transvaal, 1993, pp. 2, 4 \& 12.

${ }^{23}$ D. Rosa, The Terror of the Transvaal, 1993, pp. 10-11.

${ }^{24}$ All of this happened in a story The Last Lord of Eldorado, 1998, pp. 16 \& 26. In the same comic Flintheart also tried to kill Donald by cutting an old rope bridge down and leaving him hanging there helpless.

${ }^{25}$ D. Rosa, 'Pahikset', http://www.perunamaa.net/donrosa/artikkelit pahikset.htm.

${ }^{26}$ D. Rosa, Return to Plain Awful, 1989, pp. 18 \& 22.

${ }^{27}$ For example in Return to Plain Awful, 1989, p. 2.

${ }^{28}$ D. Rosa, A Little Something Special, published in Adventurous Uncle Scrooge McDuck 2, Gladstone Publishing, Arizona, 1998, frame 8 on the p. 10.

${ }^{29}$ D. Rosa, The Son of the Sun, 1987, pp. 8 \& 17.

\section{Bibliography}

Rosa, D., The Son of the Sun. Published in Uncle Scrooge. Gladstone Publishing, Arizona, 1987.

Rosa, D., Cash Flow. Published in Walt Disney's Uncle Scrooge and Donald Duck. Gladstone Comic Album 28, Gladstone Publishing, Arizona, 1989.

Rosa, D., Return to Plain Awful, Published in Donald Duck Adventures 12. Gladstone Publishing, Arizona, 1989.

Rosa, D., A Matter of Some Gravity. Published in Walt Disney's Comics and Stories 610. Gladstone Publishing, Arizona, 1997.

Rosa, D., A Little Something Special. Published in Adventurous Uncle Scrooge McDuck 2. Gladstone publishing, Arizona, 1998.

Rosa, D., On Stolen Time. Published in Walt Disney's Comics and Stories 610. Gladstone publishing, Arizona, 1997. 
Rosa, D., The Beagle Boys vs. the Money Bin. Published in Uncle Scrooge 325. Gemstone Publishing, Timonium, Maryland, 2004.

Rosa, D., The Terror of the Transvaal. Published in Adventurous Uncle Scrooge McDuck 2. Gladstone Publishing, Arizona, 1998.

Rosa, D., The Richest Duck in the World. Walt Disney's The Life and Times of Scrooge McDuck. Gemstone Publishing, Timonium, Maryland, 2005.

Rosa, D. The Dream of a Lifetime: Life and Times of Scrooge McDuck Companion. Gemstone publishing, Timonium, Maryland, 2006.

Rosa D., Of Ducks, Dimes and Destinies: Life and Times of Scrooge McDuck Companion. Gemstone Publishing, Timonium, Maryland, 2006.

Rosa, D., 'Why does Magica DeSpell want Scrooge's Dime?' Rintanen, J. (ed), Ankka Mestari, Don Rosa fanisivusto, (The Duck Master, fan site of Don Rosa), Viewed on 13/12/2010, http://www.perunamaa.net/donrosa/articles_magica.shtml.

Katja Kontturi is a Scholar and postgraduate in the Department of Art and Culture, University of Jyväskylä, Finland. Currently she is doing her doctoral thesis on the use and functions of fantasy and mimesis in Don Rosa's Donald Duck comics. 


\title{
I Want More! The Insatiable Villain in Children's Literature and Young Adults' Fiction
}

\author{
Karin Kokorski
}

\begin{abstract}
In children's literature and young adults' fiction, the villains, males more often than females, recurrently find their places within the stereotypical black and white pattern; they symbolize pure evil. For that reason, their love for cruelty and destruction is extraordinarily developed: most of the time, they are cruel for cruelness sake. Their behaviour helps them to achieve their ultimate goals, which is to get as much power as they possibly can. Even if they are the mightiest people in their world, they always struggle to keep their position, and they always try to increase their amount of power - they are insatiable. A prime example is the White Witch from C. S. Lewis' Narnia series, who has a whole world under her thumb. Another villain is Lord Voldemort from J. K. Rowling's Harry Potter series. He creates an atmosphere of fear, terror and destruction, and thus strengthens his powerful status. Another outstanding example is Philip Pullman, who also portrays malicious forces: in His Dark Materials, the Church is craving more and more power and consequently committing unforgivable crimes. Countless other villains haunt children's literature and young adults' fiction. By being excessively cruel and brutal, they set counter examples to socially accepted behaviour. Furthermore, their actions determine the hero's development. The more atrocious the villain is, the braver the hero has to be. The heroes stretch themselves to overcome their archenemies. Without the villains, the protagonists would not grow to their full capacities and develop their extraordinary strengths. Without the villains, the books would not be as captivating as they are. A good hero needs a 'good' villain.
\end{abstract}

Key Words: Megalomaniac desire, temptation, destruction, control, power.

$$
* * * * *
$$

\section{Introduction}

Throughout the history of literature for children and young adults, villains have haunted the tales and filled the heroes' lives with misery and despair. To get a rough definition of these villains, I will begin with drawing a picture of them. If we connect the dots, our starting point will state that the villains in this genre recurrently find their places within the stereotypical black and white pattern. From this station we make our way to position number two: according to this fairy tale like pattern the villains symbolise evil in its purest forms- their job description includes an affinity for destruction, cruelty, unscrupulousness, and often they possess seductive powers; it excludes every good character trait like moral integrity, inner justice, pity, empathy, and love. There are no shades of grey, there 
are no moments of doubt, they show no ambiguous behaviour; they are evil for evil's sake. As the villains are excessively vicious and brutal, they represent counter examples to socially accepted behaviour. From point number two we move on to point number three: the villains are very powerful and it is their ultimate goal to get as much power as they possibly can. Even if they are the strongest people in their world, they repeatedly struggle to keep their position, and they constantly try to increase their amount of power - they are insatiable. Drawing the connection to point number four, villains use violence in a variety of forms to achieve their aims; for them the end always justifies the means. In their need to dominate others, they demonstrate a social Darwinian drive: only the mightiest people are allowed to form the top of the social ('natural') scale. To complete the picture we make our way to point number five: the villains and their fights against the heroes demonstrate the central dichotomy between good and evil; evil achieves a sense of absoluteness which is only possible in fantastic literature. This genre allows us to explore several 'what if'-scenarios and, according to Pamela Gates and her coauthors, thus supports the 'human need to understand good versus evil'. ${ }^{1}$ All in all, the picture we just painted shows villains who are extremely strong and ruthless adversaries who need powerful heroes to defeat them and consequently save the world(s) and reinforce our sense of justice.

To confirm my previous propositions I chose three famous examples of villains in literature for children and young adults. First of all, I will present the White Witch, also known as Jadis, from C. S. Lewis's Narnia series. The only female villain of my talk has travelled into Narnia and cursed it with a never-ending winter. Another prime example for villainy in its purest form is Lord Voldemort from J. K. Rowling's Harry Potter series. He enjoys demonstrating his power by torturing weaker people. He creates an atmosphere of fear, terror and destruction, and thus strengthens his powerful status. Philip Pullman provides the reader with the last outstanding example: in His Dark Materials, the malicious forces of the Church are craving more and more power and consequently committing unforgivable crimes.

\section{Villains in Narnia, Harry Potter, and His Dark Materials}

In The Magician's Nephew, ${ }^{2}$ the reader meets Jadis, 'a woman [...] with a look of such fierceness and pride that it took your breath away. Yet she was beautiful too. ${ }^{3}$ She will be the White Witch in The Lion, the Witch and the Wardrobe. In both books, one of her striking characteristics is her behaviour as a temptress. In The Magician's Nephew, C. S. Lewis presents the reader with an equivalent to the Biblical scene in the Garden of Eden. In this scenario, Jadis is the serpent who wants to seduce Digory to take advantage of the forbidden fruit and use it for private purposes, not, as it is supposed to, for the greater good. She acts very cunningly using different angles to persuade him to give up the mission he tries to accomplish. Firstly, she appeals to the need she herself knows best - the insatiable need for power: 'Eat 
it, Boy, eat it; and you and I will both live forever and be king and queen of this whole world'. ${ }^{4}$ When this does not work she addresses his wish to help and heal his mother: when she will eat the apple "she will be quite well again. All will be well again. Your home will be happy again. You will be like other boys. ${ }^{5}$ Fortunately, her plan fails as she does not count on Digory's loyalty which helps him to see through her evil pattern at last. When Digory encounters Jadis in the Garden, she has already eaten one of the apples: ' $[\ldots]$ the Witch looked stronger and prouder than ever, $[\ldots]$ but her face was deadly white, white as salt. ${ }^{6}$ This whiteness also appears in The Lion, the Witch and the Wardrobe and connects her with Andersen's Snow Queen, who is 'tall and of slender figure, and of a dazzling whiteness'. ' In The Lion, the Witch and the Wardrobe, the parallel between the Snow Queen and the White Witch is obvious: 'Her face was white - not merely pale, but white like snow or paper or icing-sugar, [...]. It was a beautiful face in other respects, but proud and cold and stern. ${ }^{8}$ C. S. Lewis portrays the character Jadis / the White Witch as a beautifoul woman; her outer beauty does not reflect her inner (rotten) core. In The Lion, the Witch and the Wardrobe Narnia is under the White Witch's thumb and four human children are chosen to end her reign and be Kings and Queens of Narnia. As the Witch knows the prophecy about the children, she seeks to kill them and thus to keep control over her land of never ending winter. In this book, the White Witch also tries to seduce a boy for her purposes, and this time her attempt is successful. Her sweet tongued strategy as well as the false promises she makes work their magic with Edmund, one of the four children. The analogy to the famous temptress Circe is not the only dangerous character trait that the White Witch, or Jadis, possesses. The narrator in The Magician's Nephew also identifies Jadis as 'the Queen of Queens and the Terror of Charn', ${ }^{9}$ which is the world in which she has lived before coming to Narnia and which she has completely destroyed due to her megalomaniac drive to be the most powerful person in the world. When the children Lucy, Edmund, Susan, and Peter arrive in Narnia, this world is equally dead, as the Witch and her artificial fruitless winter have terrorised the inhabitants and forced them into hiding. According to Susan Hancock the White Witch is a 'destructive taker of life'. ${ }^{10}$

Although Lord Voldemort from J. K. Rowling's Harry Potter series is not as sweet tongued as the White Witch, these two villains have corresponding methods and ideas. Both are individual agents of evil who regard themselves as being chosen to dominate others by force. As heir to Slytherin, one of the greatest wizards of all times and co-founder of Hogwarts, Voldemort regards it as his mission to complete his forefather's goals more radically: he tries not only to purify the magical society on a microcosmic level, e.g. at Hogwarts, but also on a macrocosmic level. He seeks to "cut away the canker that infects us until only those of the true blood remain ...';1 in order to refine the magical race, Lord Voldemort plans to commit genocide. Jadis articulates the following justification for her evil deeds and is in synch with Voldemort's sanctification 
of a higher goal: '[...] that what would be wrong for you or for any of the common people is not wrong in a great Queen such as I. The weight of the world is on our shoulders. We must be freed from all rules. Ours is a high and lonely destiny. ${ }^{12}$ Included in their train of thought is the assumption that they regard it as their duty to shape the world(s) according to their ideas. Complementing this aspect of duty, and also seen in the previous quote, is their general acknowledgement of the phrase 'Might Makes Right'. In Harry Potter and the Deathly Hallows, a new statue in the Ministry of Magic confirms this maxim as it voices that 'MAGIC IS MIGHT'; ${ }^{13}$ it shows a wizard and a witch who sit on 'mounds of carved humans: hundreds and hundreds of naked bodies, men, women and children, all with rather stupid, ugly faces, twisted and pressed together to support the weight of the handsomely robed wizards' ${ }^{14}$ This statue reveals the strongest ideological statement concerning the relationship between mighty wizards and 'powerless, helpless, dumb' Muggles. ${ }^{15}$ Until Voldemort's acquisition of power, wizards have kept themselves in the background of Muggle affairs. In her book Re-reading Harry Potter, Suman Gupta states: '[i]f Muggles are left free and in control of their world it is because wizards have kind-heartedly and charitably chosen that it should be so'; ${ }^{16}$ there is no denying the fact that wizards are superior to Muggles - they have the benefit of being able to use magic. So far, however, wizards have not taken advantage of this natural supremacy. With Voldemort a new influence prevails the wizarding society: he and his followers put Muggles in their 'proper place', and 'Muggle slaughter is becoming little more than a recreational sport under the new regime'. ${ }^{17}$

Not only his wish to purify the wizarding society, and his willingness to (literally) walk over dead bodies to achieve his aim (no matter if opponent or loyal servant), but also the fact that he has divided his soul into seven parts, reveal that Lord Voldemort has moved 'beyond 'the usual evil'. ${ }^{18}$ Other signs of evil are also visible in his outward appearance: due to his facial features he is often compared to a snake; furthermore, he speaks Parseltongue - the language of snakes in Rowling's series. During the first two books, his dehumanisation is additionally emphasized by his vampire-like demeanour: in Harry Potter and the Philosopher's Stone, he needs his surrogate body to drink unicorn blood in order to strengthen himself. ${ }^{19}$ In Harry Potter and the Chamber of Secrets, he empowers himself with Ginny Weasley's spirit and life force: while his strength grows, she becomes increasingly weaker. ${ }^{20}$ In Harry Potter and the Goblet of Fire, he needs Harry's blood to acquire a solid body. ${ }^{21}$ According to J. K. Rowling, Voldemort is 'someone who is incredibly power hungry., 22

In contrast to the two individual villains mentioned above, the Church and its God figure, the Authority, in Philip Pullman's His Dark Materials exemplify organised evil. Here, the Church is construed like a three-layered wedding cake with each layer being a layer cake in itself: starting from below, the first and biggest layer consists of the belief in religion and God itself. The next layer 
contains priests, nuns, bishops, and other agents of the Church. After this stratum, the last one is called the Magisterium. It is an umbrella organisation and includes different powerful agencies of the Church. On top of the cake, there is a figurine called the Authority, who is encircled by marzipan roses - his army of angles; he calls himself ' $[\mathrm{t}]$ he Authority, God, the Creator, the Lord, [...] the Almighty'. ${ }^{23}$ This 'God', however, is not a god at all, but the first angel to be created from Dust. In the world of the first book Northern Lights, there is no papacy anymore, and 'the Church's power over every aspect of life had been absolute'. ${ }^{24}$ There are no laws which constrain the power of this Church. It holds the absolute monopoly on knowledge, values, and power. In the second book of the trilogy, a clan of witches decides to support the heroine Lyra and to fight against the Church:

For all [the Church's] history [...] it's tried to suppress and control every natural impulse. And when it can't control them, it cuts them out. [...] That is what the church does, and every church is the same: control, destroy, obliterate every good feeling. ${ }^{25}$

Throughout the trilogy, Lyra and her companions have to oppose the Church in order to keep it from destroying Dust, which settles on humans in and after puberty. 'The Magisterium decided that Dust was the physical evidence for original sin', ${ }^{26}$ and hence the Church attempts to 'save' people from Dust by forcefully separating children from their daemons. ${ }^{27}$ The process of cutting a daemon away from a child is called intercision, and as a result the child is transfigured into an empty shell, a 'zombi'. ${ }^{28}$ It is Lyra's task to save Dust and hence to save the world(s), because, in truth, Dust is a fundamental part of (human) nature and the destruction of it would mean that 'everything good will fade away and die'. ${ }^{29}$ The 'cruelties and horrors all committed in the name of the Authority, all designed to destroy the joys and the truthfulness of life, ${ }^{30}$ reveal the Authority's and the Church's fanaticism, and its immense thirst for power and its consequences. In contrast to the rebellious forces, the Church and the Authority strive to keep the minds of the people ignorant in order to freely dominate as many worlds as possible without being challenged. They try to create their own utopia in which nothing but unquestioned obedience prevails.

\section{Conclusion}

In all three cases mentioned above, the reader only knows the villains as shadowlike creatures. He gets to know about the protagonists' inner thoughts, feelings and ambitions - the villains, however, always stay two-dimensional. Whereas the heroes cannot be reduced to the traditional black and white pattern, the opponents are constantly pushed into it. To achieve their goals, the villains establish an atmosphere of threat, terror, and destruction. The White Witch, for example, turns creatures who oppose her into stone; Voldemort and the Church 
murder those who try to challenge their authority, or who are just in their way. Furthermore, the villains constantly abuse their power to support the fearsome tone of their reign. All villains in these books try to satisfy their megalomaniac and insatiable desire for total power and control. The White Witch, Lord Voldemort, and the Authority and its Church cannot live in a world which does not acknowledge their 'natural' superiority. Consequently, they try to create a new world order with them as rulers over everyone and everything.

All these similarities serve only one goal: to gain access and to keep the ultimate status of power; once the villains have tasted the flavour of power, they are addicted to it. If their strategies did not work, the protagonists would not live such a dangerous and (for the reader) exciting life. The heroes of the books grow with the obstacles; the mightier the opponent, the more the heroes have to stretch themselves in order to be successful. The more the heroes stretch themselves, the more powerful they get. The more powerful the heroes get, the closer they come to reach their real potential and develop their extraordinary strengths. The heroes of the books can only destroy their adversaries if they have reached their full capacities of power. So all in all, powerful villains need powerful heroes and vice versa. If the villain is not strong, there is no need for a strong hero. Only a 'good' villain establishes the need for a good hero. And without strong villains and powerful heroes, literature would not be as captivating and entertaining as it is.

\section{Notes}

${ }^{1}$ P.S. Gates, P.B. Steffel and F.J. Molson, Fantasy Literature for Children and Young Adults, Scarecrowpress, Lanham, MD, 2003, p. 6.

${ }^{2}$ The Lion, the Witch and the Wardrobe by C. S. Lewis was the first book out of seven books to be published in the 1950s. Here, reader and protagonists encounter the White Witch in Narnia. The Magician's Nephew, which was published five years after The Lion, the Witch and the Wardrobe, however, is plot wise the first book of the Narnia series.

${ }^{3}$ C.S. Lewis, The Magician's Nephew, HaperCollins, London, 2002, p. 48.

${ }^{4}$ Ibid., p. 150.

${ }^{5}$ Ibid.

${ }^{6}$ Ibid., p. 149.

${ }^{7}$ H.Chr. Andersen, 'The Snow Queen', Andersen's Fairy Tales By Hans Christian Andersen, Project Gutenberg, 10 October 2008.

${ }^{8}$ C.S. Lewis, The Lion, the Witch and the Wardrobe, HaperCollins, London, 1998, p. 38 .

${ }^{9}$ Lewis, The Magician's Nephew, op. cit., p. 82.

${ }^{10}$ S. Hancock, 'Fantasy, Psychology and Feminism: Jungian Readings of Classic British Fantasy Fiction', Modern Children's Literature: An Introduction. Palgrave Macmillan, New York, 2005, p. 54. 
11 J.K. Rowling, Harry Potter and the Deathly Hallows, Bloomsbury, London, 2007, p. 17.

${ }^{12}$ Lewis, The Magician's Nephew, op. cit., p. 61.

${ }^{13}$ Rowling, Harry Potter and the Deathly Hallows, op. cit., p. 198.

${ }^{14}$ Ibid., p. 199.

${ }^{15}$ Muggles are non-magical humans.

${ }^{16}$ S. Gupta, Re-Reading Harry Potter, Palgrave Macmillan, New York, 2003, p. 108.

${ }^{17}$ Rowling, Harry Potter and the Deathly Hallows, op. cit., p. 356.

${ }^{18}$ Ibid., p. 89.

19 J.K. Rowling, Harry Potter and the Philosopher's Stone, Bloomsbury, London, 2000 , p. 316.

${ }^{20}$ J.K. Rowling, Harry Potter and the Chamber of Secrets, Bloomsbury, London, 2000 , p. 340.

${ }^{21}$ J.K. Rowling, Harry Potter and the Goblet of Fire, Bloomsbury, London, 2000, p. 557.

E. Ostry, 'Accepting Mudbloods: The Ambivalent Social Vision of J.K. Rowling's Fairy Tales', Reading Harry Potter: Critical Essays. Praeger, Westport, CT, 2003, p. 96.

${ }^{23}$ Ibid., p. 33.

${ }^{24}$ P. Pullman, Northern Lights, Scholastic, London, 1998, p. 31.

${ }^{25}$ P. Pullman, The Subtle Knife, Scholastic, London, 1998, p. 52.

${ }^{26}$ Pullman, Northern Lights, op. cit., p. 371.

${ }^{27}$ A daemon is an animal that substantiates part of his/her bearer's inner nature and makes it visible to the environment. Daemons are able to talk and until puberty they are able to change form (e.g. from bird to panther).

${ }^{28}$ Pullman, Northern Lights, op. cit., p. 375.

${ }^{29}$ P. Pullman, The Amber Spyglass, Scholastic, London, 2001, p. 511.

${ }^{30}$ Pullman, The Subtle Knife, op. cit., p. 283.

\section{Bibliography}

Andersen, H. Chr., 'The Snow Queen'. Andersen's Fairy Tales By Hans Christian Andersen. Project Gutenberg: 10 October 2008, Viewed on 10 August 2010, http://www.gutenberg.org/files/1597/1597-h/1597-h.htm.

Gates, P.S., Steffel, P.B. and Molson, F.J., Fantasy Literature for Children and Young Adults. Scarecrowpress, Lanham, MD, 2003.

Gupta, S., Re-Reading Harry Potter. Palgrave Macmillan, New York, 2003. 
Hancock, S., 'Fantasy, Psychology and Feminism: Jungian Readings of Classic British Fantasy Fiction'. Modern Children's Literature: An Introduction. Palgrave Macmillan, New York, 2005.

Lewis, C.S., The Magician's Nephew. HaperCollins, London, 2002.

—, The Lion, the Witch and the Wardrobe. HaperCollins, London, 1998.

Ostry, E., 'Accepting Mudbloods: The Ambivalent Social Vision of J.K. Rowling's Fairy Tales'. Reading Harry Potter: Critical Essays. Praeger, Westport, CT, 2003.

Pullman, P., The Amber Spyglass. Scholastic, London, 2001.

—, Northern Lights. Scholastic, London, 1998.

—, The Subtle Knife. Scholastic, London, 1998.

Rowling, J.K., Harry Potter and the Chamber of Secrets. Bloomsbury, London, 2000 .

—, Harry Potter and the Deathly Hallows. Bloomsbury, London, 2007.

—, Harry Potter and the Goblet of Fire. Bloomsbury, London, 2000.

—, Harry Potter and the Philosopher's Stone. Bloomsbury, London, 2000.

Karin Kokorski is $\mathrm{PhD}$ candidate at the University of Osnabrück, Germany. She is currently working on her $\mathrm{PhD}$ dissertation about 'Violence and Justice in Children's Literature and Young Adults' Fiction'. 


\section{PART VI}

\section{Villainy On Stage and On-Screen}





\title{
'Gainst Nature Still: Reading Macbeth's Murder of Duncan
}

\section{Timo Uotinen}

\begin{abstract}
Macbeth is one of the most complex villains in literature as he seems to be aware of the gravity and consequences of his actions but, at the same time, blind to his chosen path of self-destruction. On one hand, he acknowledges a kind of fate or poetic justice, in which 'bloody instructions return to plague th'inventor'; yet, on the other hand, this does not impede his course - rather it makes him more 'bloody, bold, and resolute'. Despite Macbeth's will to succeed the metaphysical mechanism of fate proves to be stronger as the philosopher G.W.F. Hegel points out: Macbeth 'stepped out of nature itself, clung to alien Beings, and so in their service had to trample and slay everything holy in human nature, had at last to be forsaken by his gods (since these were objects and he their slave) and be dashed to pieces on his faith itself.' For Hegel, this mechanism stems from Macbeth's hostility to life, which also puts him at odds with nature. Already the murder of Duncan is characterized as unnatural and being against nature in II.iv. The perceived unnaturalness of Macbeth's villainy mediates the horror and suffering that is causes. Moreover, his villainy is unnatural because his hostility to life is also hostility towards himself - therefore it is a path of self-destruction. In my chapter, based on a reading of Hegel, I aim to problematise and critique the current understanding of nature (and culture) with this reading of Macbeth and draw attention to the mediatedness of the concept of nature. The chapter's focus will be on elucidating the ethical and social dimension of Macbeth's hostility to life and the implications it has on the concept of villainy.
\end{abstract}

Key Words: Shakespeare, Macbeth, Hegel, unnatural, nature, culture, ethics, villainy.

$* * * * *$

The murder of Duncan in Shakepeare's Macbeth is characterized as unnatural and being against nature (II.iv). It is linked to two stark images: a falcon being killed by a mousing owl; and Duncan's horses breaking out of their stalls and going wild to 'make war with mankind' and then eating each other. In these images of nature turning chaotic there are two ways in which the natural order breaks down: first, the reversal of the 'food chain' with the owl and the falcon, and the horses turning carnivorous; and second, the horses' 'second nature', their training is revoked and then return to a wild state. These two breakdowns reflect Duncan's murder. First, the virtuous king is assassinated by his subjects, the father by his children. Second, Duncan is murdered by those that conventionally are to keep him safe from harm. Macbeth is aware of these two levels in the opening soliloquy of 
I.vii, where he should be against murdering Duncan, first, as 'his kinsman and his subject' and second, 'as his host, who should against his murderer shut the door'.

This analogy of unnaturalness (the animal imagery reflecting Duncan's murder) suggests two levels that are being transgressed: a natural hierarchy and the human imposition of order. Both of these levels are in an ethical sense natural. Four hundred years later, we tend to have two senses of nature: the nature that transcends humans and the 'second nature' - the social sphere - that is created by humans. This 'second nature' is essentially what we tend to call culture. However, in the play, there is doubleness to nature as an ethical entity, which encompasses both of our modern senses of nature. The subversion of order, natural and human, is unnatural for the characters, which do not differentiate nature as we do.

A $21^{\text {st }}$ century audience would be loath to characterize the murder of Duncan as being unnatural because we would view it as a moral, a political, and even a psychological issue, whereas the Jacobean audience did not yet make such rigid distinctions between natural history, politics, theology, and ethics. For them, the assassination of an ordained king was against the natural transcendent order. Because for us the natural world is the realm of the natural sciences, both senses of unnatural would fall under 'second nature' or culture. This culturalist version empties the ethically double nature of Shakespeare - leaving at best a blank or chaotic nature - and collapses everything ethical into culture. Calling the murder of Duncan unnatural in this light seems naïve. This separation of culture and nature, for me, coincides with the separation of fact and value. However, this separation does not hold when viewed through human experience, or if we consider humans as being inherently, 'naturally', social. The radical separation of humanity (or, anything cultural) from nature - or, inner nature from outer nature - is highly problematic, as is indeed separating the ethical dimension from the sphere of human action. In this chapter I will argue that this separation is a crucial part of understanding the villainy of Macbeth. I will also try to make a connection to one of the big issues or questions of modernity, namely, the domination of nature because, for me, it is implicated by the separation. The question is then: how can Macbeth's villainous act, the murder of Duncan, be deemed unnatural and still be a strong ethical judgment for us?

G. Wilson Knight considers Duncan's murder unnatural because of what he calls 'the division of sympathy'. This division of sympathy is the poetic experience for Macbeth as well as the audience, in which the desire and need to assassinate Duncan clashes with the repercussions of breaking 'the natural evolved laws of humanity', what is attested to by the chaotic natural imagery mentioned earlier. ${ }^{2}$ So, the division of sympathy comes from seeing the two sides to Duncan's murder: Macbeth's desire to do it and the necessity of the horror that follows. The unnaturalness therefore comes from the paradoxical or disorderly state of Macbeth's consciousness. I find this position problematic because it posits the unnatural as an issue of order or cohesion and not one of murder. (This suggests 
that a murderer that does not second guess himself is natural whereas a killer with a conscience is unnatural.) $)^{3}$

Wilson Knight does interestingly connect the murder of Duncan to the transgression of 'the natural evolved laws of humanity' while he does not expand on this notion, the phrase does bear a significant resemblance to the phrase 'the laws of nature'. This resemblance underlines what it means for something to be deemed unnatural or against nature. The qualifiers 'natural' and 'evolved' place these laws of humanity in the proximity of the natural sciences. Ethical and social laws are analogous to the laws of physics or biology. This does not make sense to any mutually exclusive binary of nature and culture as it tries to pronounce ethical matters in the terms of nature.

These 'natural evolved laws of humanity' that Macbeth violates tell us about the depth and onto-epistemological status of such infractions and the relation of humanity or human nature to nature in general but little is shown about the content. There have been many attempts to formalize such a law or laws, most notably Immanuel Kant's Categorical Imperative. However, one of the most compelling accounts for the 'law' that Macbeth breaks is actually a critique of moral law. The German philosopher G. W. F. Hegel in his early theological writings ('The Spirit of Christianity and its Fate') bases this critique on a radical reading of the praxis of Jesus against what he sees as a dogmatic Judaic tradition that is perpetuated in established Christianity. Hegel counters the ethical rationalization - his main object of criticism - with a holistic metaphysics of life and love that is the basis for his vision of practical or ethical life. Life and love are what humans have in common with each other and also condition their relationship with the natural world. In simplified terms, life refers to the multiplicity of being and love is the direct, reflexive, and non-coercive relationship between lives or beings. ${ }^{4}$

At the center of Hegel's ethical vision is what Jay Bernstein - to whose reading of Hegel I am indebted - calls 'the causality of fate'. The causality of fate is social, ethical, and mythical punishment or, as Bernstein puts it, 'an ethical logic of action and reaction: to act against another person is to destroy my own life, to call upon myself revenging fates; I cannot (ethically) harm another without (ethically) harming myself. ${ }^{\prime 6}$ This is what I think Wilson Knight meant by his 'natural evolved laws of humanity'. Macbeth is all too aware of this in Act I Scene 7:

We still have judgment here that we but teach

Bloody instructions, which being taught, return

To plague th'inventor. This even-handed justice

Commends th'ingredience of our poisoned chalice

To our own lips. (11. 8-12)

He still has judgment here; the 'here' is important as it shows that he is not worried about being judged in some afterlife but still in this life. The murder of 
Duncan will return to him. He is one of Duncan's horses, his most loved captain 'the minion of his race' - and 'contending against obedience' he makes 'war with mankind'. Macbeth's fate is intertwined with his hostile acts, his grotesque decapitated end intertwined with his blood-stained path.

Macbeth's transgressions, the hostility against life, turn him into an enemy of life. His universe seems to have passed judgment on him: Lennox reports of the storm that carried lamenting and prophesized a woeful time, even 'the earth was feverous and did shake.' Ross and the Old Man tell of the day growing darker alongside the unnatural animal activity. Furthermore, Macbeth is haunted by the ghost of Banquo and images of his unborn lineage. Macbeth also seems to have condemned himself, as he could not say 'Amen' when going to kill Duncan and is unable to remove the blood. His hostility to life makes him hostile to himself. He put the poisoned chalice to his lips.

It is Macbeth's self-destructive hostility that makes the murder of Duncan unnatural. Ross comments of Duncan's assassination: 'Gainst nature still. Thriftless ambition that will ravin up thine own life's means.' The murderer consumes the means of his life. The hostility towards life is against nature in that it seeks to negate life. Murder ends life. Death in itself occurs, but pre-meditated murder is an act of extermination. It is this willing activity that turns a natural death into an unnatural murder. Adding to the unnaturalness is the fact that Duncan's murder was not done out self-preservation - Duncan was not a threat to Macbeth's life. Thus the soldier (Macbeth in the beginning of the play) is crucially different from the murderer (Macbeth in the end). This also marks the qualitative difference between Macbeth and Macduff: Macduff killed Macbeth out of selfpreservation; Duncan's death has more to do with 'thriftless ambition'.

But why does Macbeth go on with the murder even though he is aware of the causality of fate - that he will be drinking the same poison? Macbeth's blindness to his fate comes from the fact that he sees himself as an exception. For Hegel, Macbeth 'stepped out of nature itself, clung to alien Beings, and so in their service had to trample and slay everything holy in human nature, had at last to be forsaken by his gods (since these were objects and he their slave) and be dashed to pieces on his faith itself. ${ }^{, 7}$ In 'stepping out of nature' he separates himself from nature that enables him to attack 'everything holy in human nature'. Macbeth is able to make himself an exception - as he thinks - to the causality of fate because of the witches' prophecy - the clinging to alien Beings. The witches' prophecy (which Macbeth perversely misreads as another kind of fate) enables him to 'make war on humanity', to attack 'everything holy in human nature'. This excluding mediation also makes Macbeth blind to his fate, his eventual getting 'dashed to pieces'. The witches' prophesy mediates his becoming an enemy of life.

Macbeth, in stepping out of nature, loses life and love, severs his connection to nature and humanity. The direct, reflexive, non-coercive relation - that is Hegel's love - is lost and replaced with the moral medium of faith - Macbeth's faith in 
prophecy and in the 'gods' that gave it to him. This replacement of the direct relation between living beings with an extra mediating loop to an external authority is at the crux of Hegel's criticism of morality. This extra loop or medium of faith or ethics rationalized in terms of an external authority (be it the witches, God, or the Categorical Imperative) blinds Macbeth not only to self-harm but to the suffering of others and at the same time allows him to flout, not some abstract norms, but life and love.

This is part and parcel of the domination of nature - of first and second nature, of outer and inner nature. Like Nimrod and Noah for Hegel (Nimrod mastering nature with technology, and Noah with the invention of the Jewish God), ${ }^{8}$ Macbeth controls his inner nature (which is 'too full with the milk of human kindness') with the aid of the witches and Lady Macbeth (who is also a vessel for the 'murd'ring ministers') so that he can try to control outer nature with his 'bloody, bold and resolute' actions. Lady Macbeth's soliloquy in Act I Scene 5 shows the role of a certain mediation, the role of external authorities, to domination of nature - in this case murder of Duncan.

Come, you spirits

That tend on mortal thoughts, unsex me here And fill me from the crown to the toe topfull Of direst cruelty; make thick my blood, Stop up th'access and passage to remorse That no compunctious visitings of nature Shake my fell purpose nor keep peace between Th'effect and it. Come to my woman's breasts And take my milk for gall, you murd'ring ministers, Wherever in your sightless substances You wait on nature's mischief. Come, thick night, And pall thee in the dunnest smoke of hell, That my keen knife see not the wound it makes, Nor heaven peep through the blanket of the dark, To cry, 'Hold, hold.' (11. 38-52)

This speech desires a spiritual overcoming of nature, like abstract morality itself - only this is wicked. This spiritual attack on nature encapsulates Macbeth's assault on nature as if he was sheer culture. In controlling nature ethics can be detached from its substance and relegated to culture - the ethical doubleness is lost. From this position it is hard perceive what is natural from its cultural engulfment. This is why Macbeth cannot differentiate between fates - the causality of fate or the witches prophecy as fate. Therefore it is more than prudent to suspect all talk of nature as being an alibi for certain cultures: culture disguises itself as nature to justify suffering. However, Hegel does raise an important criticism: although we 
cannot immediately access nature or natural relations, does not mean that there is no ethical import from nature - it needs to be critically examined. Lady Macbeth's speech testifies to the pull of nature as ethically normative.

To conclude, the separation between nature and culture itself is a part of the perpetuated hostility towards life and nature. Just as Macbeth steps out of nature, separation of the human from nature, through some abstract morality, is a hostile act and a necessary premise for the domination of nature - the root of Macbeth's villainy. This is why the murder of Duncan is truly against nature.

\section{Notes}

${ }^{1}$ G. Wilson Knight, 'Brutus and Macbeth', The Wheel of Fire, Routledge Classics, London, 2001, pp. 156-157.

${ }^{2}$ Knight, op. cit., p. 157.

${ }^{3}$ It does, however suggest an interesting and perhaps fruitful avenue of thought when considering how the modern consciousness is being systematically made to undermine itself.

${ }^{4}$ Both life and love are hard to define due their equivocality. Hegel is also aware of the inadequacy of the metaphysics of life and love, which is why he goes on to develop his ethical vision in terms of spirit and recognition in the Phenomenology of Spirit.

5 J.M. Bernstein, 'Love and Law: Hegel's Critique of Morality', Social Research, Vol. 70, No. 2, Summer 2003, p. 394.

${ }^{6}$ Ibid., p. 394.

${ }^{7}$ G.W.F. Hegel, The Spirit of Christianity and its Fate', Early Theological Writings, University of Pennsylvania Press, Philadelphia, 1971, p. 205.

${ }^{8}$ Bernstein, pp. 397-398.

\section{Bibliography}

Bernstein, J.M., 'Love and Law: Hegel's Critique of Morality'. Social Research. Vol. 70, No. 2, Summer 2003, pp. 393-432.

Hegel, G.W.F., The Spirit of Christianity and its Fate'. Early Theological Writings. University of Pennsylvania Press, Philadelphia, 1971.

Shakespeare, W., Macbeth. Cambridge UP, Cambridge, 1997.

Wilson Knight, G., 'Brutus and Macbeth'. The Wheel of Fire. Routledge Classics, London, 2001. 
Timo Uotinen has an MA in English Philology from the University of Tampere and an MA in Modern European Philosophy from the CRMEP at Middlesex University. He is currently working on a philosophical reading of Shakespearean tragedy for his $\mathrm{PhD}$ project. 



\title{
Precious Villain ...Honourable Murderer: The Betrayer as Scapegoat in Shakespeare
}

\author{
Shala Alert
}

\begin{abstract}
In several of his plays, Shakespeare creates Edenic worlds and then provides a devil/villain who exists to throw Eden into chaos and sin. ${ }^{1}$ Iago is one such villain. Sandra Clark describes Shakepeare's Iago as 'the malignant villain' whose 'chief motive is the hatred of goodness and the desire to destroy happiness'. ${ }^{2}$ The way Iago goes about his evil work, however, is what is significant. He spreads temptation all around, ensuring that those who are vulnerable will succumb to his evil and betray those closest to them. In this way, Iago echoes the biblical figure of Satan, father of lies, tempter, ur-antagonist. Iago is in fact identified as a devil, and indirectly compared to a serpent, specifically Satan in serpentine form who despoils the proto-marriage Eden of Adam and Eve with similar machinations. Othello is also called a devil, and it is he who defiles his own marriage bed with murder and suicide. However, this is where the comparison falls short. Othello is generally categorised as a tragic hero, not a malignant villain, who succumbs to villainy because of an internal flaw. This description seems, however, to ignore the role of the devil who leads the hero into sin, and why. Claudio and Brutus, for example, are each similarly talked into villainy by a devil figure - that is, the betrayal of the innocent. As Judas is led by Satan to betray Jesus for the sake of a world needing redemption, Shakespeare must also find unwitting scapegoats to don the name of villain and betray those whose deaths will bring about the renewal of Shakespeare's worlds '[t]urn'd wild in nature' ${ }^{3}$ by the influence of the devil. Othello, Brutus and others are betrayers, Judases, who are led into sin. Sin, as their sacrifice, allows the redemption of Eden to take place.
\end{abstract}

Key Words: Shakespeare, biblical, narrative framework, scapegoat, Jesus, Judas, devil, tragedy, comedy.

$* * * * *$

In King Richard II, Shakespeare conceptualises England as a second Eden. England, declares John of Gaunt, is a 'blessed plot' set apart from other 'less happier lands' by both the sea and the favour of God. ${ }^{4}$ Clayton McKenzie suggests that England, however, is 'merely a latent paradise unless those who live in the present can ... preserve its paradisial characteristics from inward strife and outward invasion'(27). ${ }^{5}$ This second Eden is not equivalent to the biblical Eden, but there are similarities: one, the first Eden was also a blessed land and two, original Eden also needed to be preserved. Adam was its protector; when he fell the plan became one of redemption rather than preservation. In Richard II, Richard is England's 
Adam, and Gaunt blames him for the fact that England, according to McKenzie, has become 'a landscape of death and despair and stagnation'. ${ }^{6}$ In act three, the royal gardener and his assistant try to prune the garden and destroy the weeds, but it proves useless because their 'sea-walled garden, the whole land, / [i]s full of weeds'. ${ }^{7}$ The second Eden has been invaded by evil and must be redeemed; this, in McKenzie's estimation, is the motive behind the uprising that leads to Richard's death and a new king. This motif of a fallen Eden in need of redemption is one that appears in many of Shakespeare's plays and evil is variously represented by mistrust, deceit, rebellion, and the depiction of unnatural images and events. In Macbeth, for example, the appearance of witches and ghost, 'darkness [that] does the face of earth entomb, / when living light should kiss it', and the horses eating each other all point to a world turned inside out. ${ }^{8}$ Furthermore, Shakespeare's deployment of the fallen Eden motif in Macbeth shows that his pastoral vision is not limited to England. As Caroline Spurgeon declares, 'sin is a disease [and] Scotland [too] is sick'?

Shakespeare's use of the Eden motif is not limited to the garden, but is part of a much wider biblical framework that he employs to shape each plot. This story starts in Genesis with unsullied man tempted by the serpent, which has invaded the garden. Then, in Leviticus the priest is commanded to 'take from the congregation... two male goats for a sin offering'. ${ }^{10}$ The first goat must be killed, its blood used to cleanse what is contaminated by $\sin$, but the second goat is made to take the sin unto itself; it is banished from the community, thereby removing the evil and redeeming the land, and by extension the people. When the story continues in John, Jesus becomes the fulfilment of the plan of redemption; he is both the sin offering and the scapegoat. However, in Shakespeare's worlds, a Judas figure arises which seems to embody the scapegoat. The implication is that there can be no redemption without him. Just as the serpent preys upon Jesus, he must also tempt Judas because, while Jesus will resist and remain blameless, Judas must succumb to the devil and betray Jesus, since Jesus must die to redeem the congregation. Further, while the Jesus figure's sole mission is to be sacrificed (resurrection not required), it is Shakespeare's Judas who bears the taint of evil that Jesus usually is not allowed to carry. In this way, both Jesus and Judas are needed to expose the serpent and fix the decay he spreads. Finally, the restoration is complete when the evil carried by both the devil and a tainted Judas is expunged. Part of Judas' sacrifice therefore is to pay for his crime, specifically with banishment. He can remain in the community only if he receives absolution.

The world of Othello is perhaps the one that most faithfully displays this framework in the juxtaposition of its characters. There is a clear devil, Judas, and Jesus. Desdemona is Jesus. She arguably remains blameless throughout. Though her actions are sometimes questionable, the fact that they are consistent with her overall function absolves her of guilt. For example, when she secretly marries Othello, her actions mirror Jesus' where, in accordance with God the Creator's 
plan for the redemption of His world, what looked like disregard of parents was really part of the child Jesus' role as sin offering. Similarly, it can be argued that Desdemona's role in Shakespeare the Creator's plan of redemption for his world cannot be fulfilled unless she marries Othello (that is, Othello cannot betray her and she cannot die for the world), and Brabantio's disapproval of the marriage suggests that deceit is justified. Furthermore, Desdemona's death exposes the devil. That devil is Iago, and his true motive for wanting to destroy Othello is hatred: hatred of the truth, hatred of that which is honourable (Othello), and that which is pure (Desdemona). According to Norman Sanders, critics have said that '[Iago's] theatrical ancestor is the old Vice of the morality plays, who as the agent of Satan ... uttered accurate assessments of the human virtues it was his mission to pervert and destroy'. ${ }^{11}$ Furthermore, as Éfros and Thomas suggest, Iago's boast that he has survived a stabbing is actually a confession that he is the devil. ${ }^{12}$ Accordingly, it is Iago's function to find a Judas to possess, and Othello is, J. I. M. Stewart explains, the man whose soul Iago 'corrodes or subverts ... from within'. ${ }^{13}$ By the end of the play, Othello knows it too. 'Will you,' he begs Cassio, 'demand that demi-devil / [w] hy he hath thus ensnared my soul and body?' ${ }^{14}$ His realisation that he has been led into evil comes too late; he has already betrayed 'the sweetest innocent / [t]hat e'er did lift up eye' and damned himself. ${ }^{15}$ This is Othello's role as Judas.

The Eden that comprises Venice, Rhodes and Cyprus in Othello is threatened by invasion from within and without. The Turks are about to attack, but Othello defeats them and saves Eden from the visible enemy. Meanwhile, the danger lurking within Eden's borders goes unnoticed. Iago, like the devil described in 1 Peter 5:8, 'prowls around like a roaring lion, looking for someone to devour' and must be stopped. ${ }^{16}$ The job once again goes to Othello, defender of Eden. Unfortunately, he cannot use his soldier's ability to defeat this evil. Thus, Shakespeare invokes the ancient biblical ritual of redemption with Othello, Iago and Desdemona at its centre. Only when Othello has betrayed and sent Desdemona to her death is Iago's true nature revealed and his evil contained. All that is left is for the scapegoat to repent of his crime and face banishment. Othello's grief is palpable, and he blames himself for blindly trusting Iago. He does not excuse himself, but instead apologises for the wrong he has done. He is not allowed absolution, but he receives understanding. While Iago is labelled devil and villain, Othello is termed 'rash and most unfortunate" ${ }^{17}$ and his declaration that he is an 'honourable murderer... for naught did [he] in hate, but all in honour' ${ }^{18}$ is endorsed by Cassio's allowance that 'he was great of heart'. ${ }^{19}$ Lastly, his suicide mirrors Judas' and affirms the play's biblical structure.

The plots of Julius Caesar and King Richard III are both arranged according to the same biblical framework. Again we find Edens out of alignment. In Rome, one leader has just been killed in battle by his father-in-law who then takes his place. The backdrop of the play, seen in Plutarch, is corruption, and with the crowning of 
Caesar the cycle of manipulation, assassination, usurpation and manipulation will only continue. In Richard III the same kind of corruption is exposed when Richmond laments that England has been scarred by division within the ruling family, where '[t]he brother blindly shed the brother's blood, / [t]he father rashly slaughter'd his own son, / [t] he son, compell'd, been butcher to the sire'. ${ }^{20}$ It is important that he says compelled, as it assumes the existence of an evil influence behind the evil actions of men and kings whose doings, according to Gaunt, should be Christian and chivalrous. This evil influence, the serpent, has once again caused the moral deterioration of Eden, and in both England and Rome the solution is the same: the betrayal and death of the sin offering and a new beginning.

In Julius Caesar, Caesar himself is a somewhat pale approximation of the Jesus figure. While Caesar is not innocent or blameless, it is his role to be betrayed and killed for Rome's sake. Calpurnia's dream that blood would flow from Caesar's image and 'many lusty Romans [would] ... bathe their hands in it' ${ }^{21}$ and Decius' interpretation that Caesar's blood would revive and heal Rome both serve to establish his role as sin offering. Decius' words echo the sentiments of Brutus, but while Brutus' motive for killing Caesar is the salvation of Rome Cassius seems driven by his contempt for Caesar. Further, when Brutus does not readily share his thoughts, Cassius manipulates him, goading him to agree that Caesar must die. Cassius, therefore, is the devil, but like Caesar he is a poor facsimile. As devil, Cassius claims not to fear heaven. '[W]hen the cross blue lightning seemed to open / [t]he breast of heaven,' he declares, 'I did present myself / [e]ven in the aim and flash of it'. ${ }^{22}$ However, Cassius is not heartless, and his lament that Brutus does not love him rings true in the tone of their quarrel in act four. He simply has a function to perform; just as Caesar must die, Cassius must tempt Judas.

Brutus is Judas. His necessary betrayal of both his dearest friend and his own honour demonstrates Brutus' sacrificial role as scapegoat. Brutus will suffer, but Judas must bear his burden. Although Caesar's hands are just as bloody as his murderers', Shakespeare has Brutus clarify that Caesar is not being punished for wrongdoing, but for Brutus' fear that he will commit future wrongs. Brutus' impression of Caesar as an unhatched egg that must be destroyed before it hatches suggests that the crime that Brutus will commit involves the betrayal of a blameless Jesus. Furthermore, John Lawlor's conclusion that in Shakespeare 'the secondary agents of evil suffer as their major punishment ... the nightmare vision of the innocent whom they have given to death ${ }^{23}$ lends a particular interpretation to the appearance of Caesar's ghost. It establishes first that Brutus is not the primary agent or source of evil. Secondly, Brutus' statement that the ghost only appears to reveal the hour of his death can also be read in this way: that, like the devil appears to tempt him, the ghost comes to tell Judas how to die, and when. This reinforces Shakespeare the Creator's use of the biblical redemption narrative to order the world within the play. Judas must follow his prescribed fate as scapegoat and his eventual death, the last in the chain, will spark Rome's rebirth. 
In the England portrayed in Richard III, Richard of Gloucester fills two roles in Shakespeare's redemption narrative. He is both Judas and the devil. One could argue that he is the devil and Buckingham Judas, since Richard spends half the play tempting Buckingham to evil. However, because one of Judas' principal roles is to betray and bring death to the innocent, and Buckingham refuses to do so, he disqualifies himself. It is Richard who betrays the "poor princes... tender babes... unblown flowers'. ${ }^{24}$ Therefore, since the princes are the sin offering, Richard is the scapegoat. Judas, however, is responsible only for the death of Jesus. He is led into evil, but is not evil. The evil one is the serpent. Because he indiscriminately spreads death and hatred everywhere he goes, Richard is also the devil. But he does not only hurt others; he also hurts himself. The villain's work in Richard III, Lawlor explains, is only complete when the evil within him has grown to such proportions that he alienates himself. ${ }^{25}$ This is what happens to Richard. As one man, both the devil and Judas his puppet are isolated, banished from the community. Richard remarks that no one loves him and no one will mourn his death, and why should they, he wonders, if 'I myself / [f]ind in myself no pity to myself ${ }^{26}$. Isolation, however, is not punishment enough, and Judas must again face the irrevocable banishment: death. The pathos implicit in Richard's anguished acceptance of his alienation, in light of A.P. Rossiter's view of Richard as God's 'avenging angel', emphasises Richard's sacrifice as scapegoat - that is, bearing the burden of evil, for the sake of the world - much more than his role as devil. ${ }^{27}$

Outside of the realm of the tragic, Shakespeare's redemption narrative unfolds somewhat differently. In Much Ado About Nothing, we see what is perhaps the most literal Eden of all. Messina is not a fictional place; it is real, like England or Venice. However, though men retain their titles in Messina, their respective ranks in the outside world do not decide their experiences in Messina. In Messina, a fatherless girl of no special social position may receive a marriage proposal from a prince. The use of a masquerade scene further removes rank and promotes equality. Lastly, the fact that Don Pedro and his entourage have come to Messina straight from battle makes the town a haven. When soldiers arrive there, '[w]ar thoughts / [leave] their places vacant, [and] in their rooms / [c]ome thronging soft and delicate desires'. ${ }^{28}$ Furthermore, the main characters of the redemption narrative are easily identified. John the Bastard admits that he is 'a plain-dealing villain'. ${ }^{29}$ Because of previous wrongdoing, everyone knows him to be a devil, but at the start of the play he has Don Pedro convinced that he is reformed, even as he is planning Eden's destruction. Hero is Jesus, and her name reflects her role. She is the necessary sacrifice; her death allows for the revelation of John's villainy and the redemption of Eden. As the sin offering, Hero is innocent in every sense of the word. Unlike Desdemona who protests her innocence to the end, Hero does not deny Claudio's accusations. Lewis Carroll wonders '[w]hy in the world did not Hero... prove an 'alibi' in answer to the charge.$^{30}$ I want to suggest that Hero's silence is meant to mimic the portrayal of Jesus in the book of Isaiah as 'a lamb 
that is led to slaughter, [a]nd like a sheep that is silent before its shearers, [s]o He did not open His mouth'. ${ }^{31}$ Claudio, in the same scene, is vocal and loud, and it is this contrast that establishes his antagonistic role as Judas to Hero's Jesus.

As Judas, Claudio is perhaps too easily tempted by John. Even without proof John is able to convince Claudio that Don Pedro has deceived him. The prince, however, is so loyal that he knowingly joins Claudio in exile when Claudio inflicts upon himself Judas' banishment. So why does Claudio believe the word of an established villain over that of his friend? Perhaps, like Hero accepts her role as Jesus, Claudio is meant to willingly accept the fate of Judas and his burden of sin. Like Brutus, Othello and Richard, Claudio betrays Jesus and sends him to his death. Claudio also has to endure exclusion from the congregation, but unlike the others he is eventually permitted to atone for his sin; he is the only Judas allowed back into the company once the threat of the serpent is discovered and neutralised. The fact that Much Ado is a comedy likely has something to do with what Shakespeare does with Judas at the end. It is also important that Hero is the only Jesus resurrected. Claudio's act of atonement allows for her resurrection, which in turn allows for his absolution, and Judas does not have to die for Eden to be redeemed.

Mine is not a theological argument, but rather an attempt to identify and examine a common pattern in Shakespeare, specifically a pattern that has biblical roots. The use of the Eden motif can be said to be an appeal to the pastoral, even in tragedy. David Young contends that the pastoral offered writers like Shakespeare an ideal to believe in, an alternative to urban life. ${ }^{32}$ Irving Ribner likewise describes Shakespeare's tragedy as an exploration of man's relationship to evil, and an attempt to find a way to redemption, much like religion. ${ }^{33}$ Both ideas help to illuminate Shakespeare's use of the redemption narrative in both tragic and comic realms. Even as he explores men's human failings and flaws, and makes of them Judases, betrayers, murderers, he offers them salvation, the salvation that comes with participating in the redemption of the world, even if they never live to enjoy the replenished Eden.

\section{Notes}

${ }^{1}$ W. Shakespeare, Othello, N. Sanders (ed), Cambridge University Press, UK, 1984, V.ii.233, 291.

2 L. O'Dell, Shakespearean Scholarship: A Guide for Actors and Students, Greenwood Press, Westport, CT, 2002, p. 98.

${ }^{3}$ W. Shakespeare, Macbeth, K. Muir (ed), Routledge, London, 1991, II.iv.16.

${ }^{4}$ W. Shakespeare, Richard II, P. Ure (ed), Methuen \& Co. Ltd., London, 1966, II.i.50, 49 . 
5 C.G. McKenzie, Emblems of Mortality: Iconographic Experiments in Shakespeare's Theatre, University Press of America, Maryland, Oxford, 2000, p. 27.

${ }^{6}$ Ibid., p. 27.

${ }^{7}$ Shakespeare, Richard II, op. cit., III.iv.43-44.

${ }^{8}$ Shakespeare, Macbeth, op. cit., II.iv.9-10.

${ }^{9}$ C. Spurgeon, Shakespeare's Imagery and What It Tells Us, Cambridge University Press, Cambridge, UK, 1935, p. 332.

${ }^{10}$ The NIV Study Bible, K. Barker (ed), Zondervan Publishing House, Michigan, 1995, Lev. 16:5b.

11 N. Sanders, 'Introduction', W. Shakespeare, Othello, N. Sanders (ed), Cambridge University Press, UK, 1984, p. 25.

12 A. Ėfros \& J. Thomas, The Craft of Rehearsal: Further Reflections on Interpretation and Practice, Peter Lang Publishing, Inc., New York, 2007, p. 140.

${ }^{13}$ Quoted in N. Sanders, 'Introduction', p. 27.

${ }^{14}$ Shakespeare, Othello, V.ii.298-299.

15 Ibid., V.ii.198-199.

${ }^{16}$ The NIV Study Bible, 1 Peter 5:8.

${ }^{17}$ Shakespeare, Othello, V.ii.280.

${ }^{18}$ Ibid., V.ii.291-292.

${ }^{19}$ Ibid.,V.ii.357.

${ }^{20}$ W. Shakespeare, King Richard III, M. Birch (ed), Longman, UK, USA, 1994, V.v.24-26.

${ }^{21}$ W. Shakespeare, Julius Caesar, M. Spevack (ed), Cambridge University Press, UK, New York, Melbourne, 1988, II.ii.78-79.

${ }^{22}$ Ibid., 50-52.

${ }^{23}$ J. Lawlor, The Tragic Sense in Shakespeare, Chatto \& Windus, London, 1960, p. 125.

${ }^{24}$ Shakespeare, King Richard III, op. cit., IV.iv.9-10.

${ }^{25}$ J. Lawlor, The Tragic Sense in Shakespeare, p. 126.

${ }^{26}$ Shakespeare, King Richard III, op. cit., V.iii.205-206.

27 A.P. Rossiter, Angel With Horns and Other Shakespeare Lectures, G. Storey (ed), Longmans, Green and Co., London, 1961, p. 20.

${ }^{28}$ W. Shakespeare, Much Ado About Nothing, F. H. Mares (ed), Cambridge University Press, Cambridge, UK, New York, Melbourne, 1988, I.i.227-229.

${ }^{29}$ Ibid., I.iii.23-23.

${ }^{30}$ Quoted in J. Lawlor, The Tragic Sense in Shakespeare, p. 102.

${ }^{31}$ The NIV Study Bible, Isa. 53:7b.

32 D. Young, 'Pastoral Poetry and Drama', Shakespeare: Much Ado About Nothing and As You Like It: A Casebook, J. R. Brown (ed), Macmillan Education, England, 1979. 
${ }^{33}$ I. Ribner, Patterns in Shakespearian Tragedy, Methuen and Co. Ltd., London, 1960.

\section{Bibliography}

Clark, S., Hutchinson Shakespeare Dictionary: An A-Z Guide to Shakespeare's Plays, Characters, and Contemporaries. Hutchinson, London, 1986.

Efros, A. \& Thomas, J., The Craft of Rehearsal: Further Reflections on Interpretation and Practice. Peter Lang Publishing, Inc., New York, 2007.

Lawlor, J, The Tragic Sense in Shakespeare. Chatto \& Windus, London, 1960.

McKenzie, C.G., Emblems of Mortality: Iconographic Experiments in Shakespeare's Theatre. University Press of America, Maryland, Oxford, 2000.

NIV Study Bible (The). Barker, K. (ed), Zondervan Publishing House, Michigan, 1995.

O'Dell, L., Shakespearean Scholarship: A Guide for Actors and Students. Greenwood Press, Westport, CT, 2002.

Ribner, I., Patterns in Shakespearian Tragedy. Methuen and Co. Ltd., London, 1960 .

Rossiter, A.P., Angel With Horns and Other Shakespeare Lectures. Storey, G. (ed), Longmans, Green and Co., London, 1961.

Sanders, N., 'Introduction'. Othello. Sanders, N. (ed), Cambridge University Press, UK, 1984.

Shakespeare, Wm. Julius Caesar. Spevack, M. (ed), Cambridge University Press, UK, New York, Melbourne, 1988.

—, King Richard II. Ure, P. (ed), Methuen \& Co. Ltd., London, 1966.

— - King Richard III. Birch, M. (ed), Longman, UK, USA, 1994.

—, Macbeth. Muir, K. (ed), Routledge, London, New York, 1988. 
—, Much Ado About Nothing. Mares, F.H. (ed), Cambridge University Press, Cambridge, UK, New York, Melbourne, 1988.

—, Othello. Sanders, N. (ed), Cambridge University Press, UK, 1984.

Spencer, J.J.B. (ed), Shakespeare's Plutarch. trans. North, T., Penguin Books, England, USA, Australia, 1964.

Spurgeon, C., Shakespeare's Imagery and What It Tells Us. Cambridge University Press, Cambridge, UK, 1935.

Young, D., 'Pastoral Poetry and Drama'. Shakespeare: Much Ado About Nothing and As You Like It: A Casebook. Brown, J.R. (ed), Macmillan Education, England, 1979.

Shala Alert is an MPhil student at the University of the West Indies. Her research is in the area of Caribbean masculinities, specifically the work of Guyanese author Edgar Mittelholzer, and how the major theories of psychoanalysis, especially as regards the formation of identity, can be applied to Mittelholzer's work. In addition, she loves Shakespeare and would like to become more involved in Shakespeare studies later on. 



\title{
The Sow that Repeatedly Devours her Piglets: The Villain on the Nigerian Stage
}

\author{
Tiziana Morosetti
}

\begin{abstract}
In his essay 'And after the Wasted Breed?', the Nigerian playwright Femi Osofisan comments on his choice to respond to Wole Soyinka's drama The Strong Breed (1964) with his own play No More The Wasted Breed (1982), arguing that Soyinka 'could not but read history as a catalogue of human 'wastage' [...]. Africa, like the Ireland of James Joyce, is the sow that repeatedly devours her own piglets'. The theme of the scapegoat, central to both authors, is also central in describing what the 'villain' might be on the Nigerian stage. This chapter will aim at focusing on how both Soyinka and Osofisan subvert the stereotype of the 'scoundrel', identified now as a rebellious element, now as a common criminal, in order to sympathise with all those - thieves, robbers, and saboteurs - that both regard as a product of their own corrupt society. In Soyinka's The Trials of Brother Jero (1964) and Jero's Metamorphosis (1973), and Osofisan's Once upon Four Robbers (1978), Nigeria is actually portrayed as a 'sow that repeatedly devours her own piglets', but in all this folly both authors reasonably make a clear distinction between 'true' and 'false' villains.
\end{abstract}

Key Words: Wole Soyinka, Femi Osofisan, Nigerian theatre, political criticism, evil, good.

$* * * * *$

\section{Different Stages of Evilness}

In his essay 'And after the Wasted Breed?' (2001), the Nigerian playwright Femi Osofisan comments on his choice to respond to The Strong Breed (1964), a highly successful drama by the Nobel Prize winner Wole Soyinka, with his own play No More the Wasted Breed (1982), arguing that Soyinka 'could not but read history as a catalogue of human 'wastage' [...]. Africa, like the Ireland of James Joyce, is the sow that repeatedly devours her own piglets."

Scholars on African drama may already be familiar with the active and amicable dispute between Soyinka (1934- ) and Osofisan (1946- ), one that is representative of the more general distance between 'literary' drama and 'political' theatre in the Nigerian context. ${ }^{2}$ It will be sufficient to say here that notwithstanding the relatively few years between them, and even though they share a political conception of literature, Soyinka and Osofisan are mainly divided by their attitude towards tradition and mythology, as well as by the role they ascribe to intellectuals and writers on the political scene. Both playwrights are concerned with Nigerian politics, and with the challenges that the country has met since its 
independence in 1960; however, whilst Soyinka is deeply interested in the aesthetical and philosophical implications of mythology and tradition, with specific reference to the Yoruba world, Osofisan, a Yoruba himself, is more actively committed to urging his audience towards the need for political changes, and his plays 'may be said to dramatise the following questions: how are revolutionaries made; of what stuff are they made; in what consists the rightness and authority of their cause? ${ }^{3}$

The 'scapegoat' motive is the basis of The Strong Breed and No More the Wasted Breed, and a most notable example of the gap between the two. The theme is a major one in both literature and anthropology; however,

no assiduous reading of The Golden Bough is necessary [...]. Animal scapegoats were still a regular feature of Yoruba towns in the years of Soyinka's childhood, and even human ones were commonly found well into the present century. ${ }^{4}$

While in Soyinka's drama the protagonist, Eman, dies after sacrificing himself to save the life of the designated victim, Ifada, an helpless and unwilling boy, in Osofisan's version a fisherman, Saluga, ultimately challenges both the gods and the authorities in the attempt to save the life of his friend Biokun. But the 'scapegoat' motive also allows for a wider exploration of what the word 'villain' might imply in the Nigerian (literary) context. Are the villagers in Soyinka's drama evil? Is this a case of a collective villainy at the expense of the hero? Could the protagonists in Osofisan's drama, on the other hand, be identified as villains because of their challenging the local authorities, and for refusing to serve what is perceived as the collective interest? Or should they be seen as prophets, or heroes, as they stand against the community in the attempt to open its eyes on the cruelty and uselessness of certain traditions?

The answer to such questions is not an easy one. Eman is certainly portrayed as a hero, but the exceptionality of his character is specifically linked to his wanting to spare Ifada an end that the boy is not able to choose, nor to understand; Eman clearly states that becoming a scapegoat is something that the victim should at least be able to undertake out of his own will, but not for one moment does he doubt the necessity for such a ritual to be carried out. Soyinka is more interested in portraying the characters' psychology than in presenting political propaganda, and in the process the audience is presented with values, such as courage and respect for the forefathers, that are not entirely negative, and even justify the community's attachment to the cleansing ritual. In No More the Wasted Breed the playwright's hand pushes more heavily in the direction of identifying Saluga with a hero. However, the fisherman's bold approach to the gods and his offensive, outrageous language are portrayed by Osofisan as brave exactly as they challenge not only the status quo, but also the audience's sensibility, which might not entirely share 
Saluga's ideas (as we shall see further on, Osofisan is in fact an indomitable agent provocateur in consistently presenting his audience with controversial characters).

The fact is that Nigerian society is so much the result of overlapping traditions, cultures and instances, and so vexed is it with such hoary problems as widespread and transversal corruption, the increasing gap between urban and rural contexts, or the turmoil linked to the oil business, that it is almost impossible to talk of villains and villainy without considering a number of exceptions and ambiguities. As a general rule, Nigerian drama almost invariably implies a juxtaposition between a powerful and privileged minority (the authorities, both central and local) and a suffering and oppressed majority (the people), and Soyinka and Osofisan make no exception, given that their authorities, be they human or supernatural, and justified or not, are portrayed as oppressive, threatening, obscure and violent. But this does not imply that the juxtaposition is necessarily one of evil and good, because the precarious life of most Nigerians implies that many of them, at various levels, cannot but seize the least occasion to improve their conditions, even if this implies doing it at the expense of others, and because the majority, for the complications inherent in a state in which hundreds of ethnic groups co-exist on the same troubled soil, are rarely unified against the minority. Nigeria may thus be considered, as John Pepper Clark-Bekederemo literally did in his masterpiece The Raft (1964), as a boat adrift on rough waters, one in which it might be easier to distinguish between different 'stages' of evilness, rather than between evil and good.

\section{The Jero Plays: 'Big' and 'Small' Villains}

The two Jero plays were written over a span of time of about ten years (being published in 1964 and 1973 respectively), and the atmosphere is consequentially quite different, The Trials of Brother Jero being a variation on the trickster character in all its implications, while Jero's Metamorphosis shares with most works published after the Biafra war (1967-1970) a more evident and strong political meaning, set as it is, moreover, to the background of the so-called Bar Beach Show. ${ }^{5}$

In the first of the two plays, mainly set on Lagos Bar Beach, the action revolves around three main characters, Jero, a false prophet; Chume, an ordinary (and quite unsuccessful) man, who is one of Jero's most affectionate clients; and Amope, Chume's wife, who is trying to catch up with Jero for an unsettled debt. The character of Jero is modelled after the traditional 'trickster' figure, a 'popular hero ${ }^{6}$ of West African narratives. The trickster, who is sometimes also a mediator between men and gods, does not necessarily live outside the law (even if law does not represent an obstacle to his plans), and is provided with a cunning and sharp mind that is always ready to turn situations to his own favour. In the case of Jero, the villainy is added by his being a false prophet, therefore cheating his own fellow countrymen, and by his profiting from the disgrace of others. 
Jero's Metamorphosis, on the other hand, features an extended cast, which includes Jero, Chume, various prophets and some government officials. The story is set on the background of the already mentioned Bar Beach Show, which, as Osofisan remembers, "soon turned into a regular carnival' ${ }^{7}$ during the Gowon government. The prophecy business, which was already a common sight on Bar Beach, profited, as did other trades, from the crowds that the executions attracted. In Jero's Metamorphosis, the action is centred on Jero's attempt - after he obtains an official document stating the government's intention to get rid of all the charlatans operating on the Bar Beach, in order to establish more lucrative trades around the Show - to gather all prophets under one organization and build up a monopoly of the prophecy business that can impose its presence on the Bar Beach. Needless to say, the plan is eventually achieved by Jero, who in the process is able to convert to his mission not only Chume, but also Sister Rebecca, a former secretary of the Chief Executive Officer, who is completely bamboozled by Jero, and represents the only real victim of the whole play.

If in The Trials of Brother Jero Soyinka presents the audience with a portrait of the petty businesses that grow daily out of economic pressures and a general lack of proper jobs (as he does, with an altogether different perspective, in works such as The Road, in which improvised businesses are at the core of the characters' lives), Jero's Metamorphosis provides us with a more complete survey of the social and economic struggles of Nigeria, as well as with a biting portrait of the widespread corruption amongst officials of all ranks. If Jero is, in a way, the only villain in The Trials, and his action is somewhat justified both under the traditional frame of trickster stories, and the relatively little damage that his false prophecies cause around him, in Jero's Metamorphosis the Bar Beach Show changes everything, adding gloom to the whole story, turning Jero the trickster into a cynical entrepreneurial mind, and exposing the horror not only of public executions, but also of their commodification.

We could therefore say that the Jero plays provide us with villains of all 'sizes', 'small' villains like Jero and his fellow prophets, who earn their living out of other people's ingenuousness, and 'big' villains like the government officials, whose interests are much wider than Jero's and the methods far more seriously damaging. In Jero's Metamorphosis this contraposition is made particularly clear by the fact that, for the whole action of the play, Jero tries to move a step further towards the importance and power of the Big Villain portrayed in a framed painting hanging from his wall, and when the action is over, leaving Jero a rich and powerful man, his metamorphosis is complete. 'After all' he says in his last line, seating at his desk after replacing the framed picture with a larger one of himself, it is the fashion these days to be a desk General. ${ }^{8}$ 


\section{Once upon Four Robbers: 'Real' and 'False' Villains}

Once upon Four Robbers, written in 1978, was rehearsed and performed almost in secrecy, so strong was the hostility of the establishment at the time towards Osofisan, ${ }^{9}$ who, in his collection of essays Insidious Treasons (2001), comments on his play as follows:

I was concerned to demonstrate how the robbers, with all their repellent acts, were themselves victims of our unjust socioeconomic set-up; and how the rest of us were already implicated in some form or other of public looting, undetected because more covert. $^{10}$

The action of the play revolves around four robbers (Hasan, Angola, Alhaja and Major), whom a Muslim preacher, moved by the account of their poor and troubled life, presents with the gift of being able to put a spell on the victims they wish to rob, so that these do not offer any resistance. The gift, however, is subject to three conditions: only wealthy people must be robbed; the robberies will be exclusively conducted in public places; and no one must be killed in the process. In the second part of the play, Major betrays his accomplices, and, after being robbed by the same policemen who are arresting him, is put in jail and sentenced to death. Alhajah tries to save him, but she is also arrested by the police and sentenced to death. The two characters are at this point brought forward amongst an enraged crowd, and only the appearance of the preacher on stage can save them from being lynched. In the final scene, the preacher asks the audience to decide what they want to be done with the robbers: if the audience chooses for the liberation of the robbers, these will perform robbery at the expense of the dancing choir; otherwise, the lights will go down on their execution.

Here, compared to Soyinka's Jero plays, we are confronted with an even greater variety of villains. The robbers are the 'obvious' villains, both on stage and in real life, even though they are declared to be 'of the race victims are made of,'11 whilst the spectators of the Bar Beach Show, on the other hand, are at the beginning of the play called 'vultures' and 'hounds, ${ }^{12}$ whose only wish is that to feed on the spectacle of someone else's death. Also, the policemen are as corrupted as the robbers, and the government is seen as the 'biggest' villain of all, lying behind all the turmoil, hate, and mutual contempt that lies amongst fellow Nigerians.

To make the audience aware of such perspective, the play employs the traditional frame of story-telling, through which Osofisan attempts to challenge the division between stage and audience that characterizes both European drama and Nigerian 'literary' drama, in order to challenge the audience to step up with their own views. Osofisan's final thesis, as in other dramatic productions, is that people are products of their own society, and therefore, if society suffers from an unfair 
distribution of sources amongst its members and even threatens their own lives, its members are allowed to react in ways that cannot always be justified (the preacher's rules are clearly against any blind defence of robbery), but which are certainly the result of their own social and political environment.

Osofisan distinguishes then very clearly between 'real' and 'false' villains, subverting the order of things and trying to expose the evil behind the officially moralizing action of the government, as he tries to underline the conditions of utter misery, both material and moral, that lie at the bottom of such phenomena as armed robbery. In his view,

the violence with which the state confronts violent robbers cannot but beget greater violence on the part of robbers and others whom objective conditions compel to defy the terrorism of the state. ${ }^{13}$

\section{Conclusions}

Osofisan's drama, then, in my view, challenges Soyinka's, as it tries to subvert the vision of a country in which all are, at various level, villains, by replacing it with a more politically-oriented distinction between evil and good. However, Osofisan's vision might not end up being, in the end, much more optimistic than Soyinka's, because the subversion of the concept of 'villain' inherent in Once upon Four Robbers also implies a complete distortion of the word 'victim', which risks leading to an upside-down society in which nothing is what it seems, and all is folly without any reasonable logic. On the other hand, it is not entirely accurate to say that Soyinka has promoted a vision of Nigerian society as a place where no one can be trusted, and the situation is really homo homini lupus, because the idea of portraying 'small' and 'big' villains all intent on climbing the ladder for success does in its turn expose that success as vulgar, unreliable, and something to object.

Both playwrights therefore challenge the image of Nigeria as 'a sow that devours her own piglets', as for both it is still possible to address one's blame against the 'real' or 'bigger' villains', pitying the other for being forced to be what they are.

\section{Notes}

${ }^{1}$ F. Osofisan, 'And After the Wasted Breed?', The Nostalgic Drum: Essays on Literature, Drama and Culture, Africa World Press, Trenton-Asmara, 2001, p. 253.

${ }^{2}$ The exponents of the 'literary' drama or 'first' generation of Nigerian dramatists are, besides Soyinka, John Pepper Clark-Bekederemo, Ola Rotimi, and Zulu Sofola; those of the 'political' theatre or 'second' generation are, besides Osofisan, Kole Omotoso, Bode Sowande, Olu Obafemi, and Tess Onwueme. See O. 
Obafemi, Contemporary Nigerian Theatre: Cultural Heritage and Social Vision, Bayreuth African Studies, Bayreuth, 1996.

${ }^{3}$ B. Jeyifo, The Truthful Lie: Essays in a Sociology of African Drama, New Beacon Books, London, 1985, p. 52.

${ }^{4}$ G. Moore, Wole Soyinka, Evans Brothers Limited, London, 1978, p. 47.

${ }^{5}$ The expression refers to a measure of the Gowon government (1966-1975) that attempted to overcome the increasing widespread of armed robbery by sentencing to death those found guilty, and executing them in public on, amongst other locations, Bar Beach, which is one of the two largest beaches of Lagos. A number of plays revolve around the 'Bar Beach Show', beside those here under account: Osofisan's Aringindin and the Nightwatchmen (1991), Z. Sofola's The Operators (1973), and E. Irobi's Hangmen also Die (1989). See C. Dunton, Make Man Talk True: Nigerian Drama in English since 1970, Hans Zell Press, London, 1992.

${ }^{6}$ R. Priebe, 'Soyinka's Brother Jero: Prophet, Politician and Trickster', Critical Perspectives on Wole Soyinka, J. Gibbs (ed), Heinemann, London-Ibadan-Nairobi, 1980, p. 80.

${ }^{7}$ F. Osofisan, 'The Revolution as Muse: Drama as Surreptitious Insurrection in a Postcolonial, Military State', Insidious Treasons: Drama in a Postcolonial State. Essays, Opon Ifa Readers, Lagos, 2001 [1981], p. 63.

${ }^{8}$ W. Soyinka, Jero's Metamorphosis, Collected Plays, Vol. 2, Oxford University Press, 1974, p. 213.

${ }^{9}$ See F. Osofisan, 'The Revolution as Muse' op. cit., pp. 79-81.

${ }^{10}$ Ibid., pp. 62-63.

${ }^{11}$ F. Osofisan, Once upon Four Robbers, Heinemann Educational Books Nigeria, Ibadan, p. 53.

${ }^{12}$ Ibid., p. 6.

${ }^{13}$ C. Amuta, The Theory of African Literature, Zed Books, London, 1989, p. 168.

\section{Bibliography}

Amuta, C., The Theory of African Literature. Zed Books, London, 1989.

Dunton, C., Make Man Talk True: Nigerian Drama in English since 1970. Hans Zell Press, London, 1992.

Jeyifo, B., The Truthful Lie: Essays in a Sociology of African Drama. New Beacon Books, London, 1985.

Moore, G., Wole Soyinka. Evans Brothers Limited, London, 1978. 
Obafemi, O., Contemporary Nigerian Theatre: Cultural Heritage and Social Vision. Bayreuth African Studies, Bayreuth, 1996.

Osofisan, F., No More the Wasted Breed, in Morountodun and Other Plays. Longman Nigeria, Ikeja, 1982.

—, Once upon Four Robbers. Heinemann Educational Books Nigeria, Ibadan, 1991.

—, 'And After the Wasted Breed?'. The Nostalgic Drum: Essays on Literature, Drama and Culture. Africa World Press, Trenton-Asmara, 2001.

-, 'The Revolution as Muse: Drama as Surreptitious Insurrection in a Postcolonial, Military State'. Insidious Treasons: Drama in a Postcolonial State. Essays. Opon Ifa Readers, Lagos, 2001 [1981], pp. 50-83.

Priebe, R. 'Soyinka's Brother Jero: Prophet, Politician and Trickster'. Critical Perspectives on Wole Soyinka. Gibbs, J. (ed), Heinemann, London-Ibadan-Nairobi, 1980.

Soyinka, W., The Strong Breed, Collective Plays. Oxford University Press, 1973 [1964], pp. 113-146.

—, The Trials of Brother Jero, Collected Plays. Oxford University Press, 1974 [1964].

—, Jero's Metamorphosis, Collected Plays, Vol. 2. Oxford University Press, 1974 [1973].

Tiziana Morosetti is at present a research fellow at the University of Bologna. 


\title{
You don't Make Up for Your Sins in Church: Dilemmas of Moral Development in Scorsese's Mean Streets
}

\author{
David Sousa
}

\begin{abstract}
Martin Scorsese's Mean Streets is here interpreted as a film about growing up, Kohlberg's scheme of moral development offering the best key to read the film's approach to human nature. It would be naïf to present its main characters, the mafia apprentices and small crooks Charlie and Johnny Boy, merely as victims of their social environment. Drawing from his Catholic background, Scorsese's builds his characters has agonizing and twisted portraits of the moral development of consciousness in a town (the mafia domains of Little Italy) where street rules become the law of the land, making violence and corruption acceptable. In childish Johnny Boy, consciousness retreats to boyhood, it refuses to grow. In Charlie though, consciousness is very much alive: it splits room in his mind with his commitment to the mafia, until it starts ripping him apart. The sort of obedience it claims cannot be shared.
\end{abstract}

Key Words: Moral development, morality, consciousness, Catholicism, Scorsese.

$* * * * *$

Martin Scorsese's, Mean Street starts with a prologue: a voice over we can later identify as the priest's tells main character Charlie - 'you don't make up for your sins in church; you do it in the streets, you do it at home', the voice adds. 'Home' and 'streets' stand for the two realms in Hannah Arendt's scheme in The Human Condition: private and public. ${ }^{1}$ In Arendt's terms, home is the realm of comfort and safety, away from the exposure of the public space. But the admonition at the prologue puts both together, for the pressure of others can be left behind, but not the pressure within, that is, the inner voice of consciousness. Again in Arendt's footsteps, ${ }^{2}$ consciousness is the active memory of deeds done; its demand for reparation cannot be shut out. Guilt is thus the key concept contained in the voice over's advice - it is the precondition of moral development. The idea that one could get rid of it through prayer in church, it denounces, is naïf and misses the all point of Christian moral teachings. Christianity broke away from mystical, contemplative traditions to become a religion of action. Recognizing the human as less than saint, it bounds the person to continuous improvement through (inter)action in the social world. Guilt is the reminder of one's less-than-saint condition; aspiration to improvement, guided by the moral commandments, finds expression not only in refraining from sin, but also in 'making up' through compassive action. 
Scorsese chooses to focus on the streets ${ }^{3}$ and calls them 'mean'. What is mean about the streets is not so much that these are dominated by twisted street rules those of Little Italy in the early Seventies, dominated by the mafia culture. Along the film, as Charlie strives to make up for his sins and pull his friend Johnny out of trouble, the streets keep offering occasion for further sinking. Mean Streets is by no means a mafia film but, of course, the fact that violence and corruption are part of the common standards only adds up.

There's a clear autobiographical dimension to this film, otherwise Martin Scorsese would not have to dismiss the accusation of putting too much of himself in the film in a 2003 documentary about that period in America cinema. ${ }^{4}$ In the interview that goes together with the 2004 DVD edition of the film, though, he does state that Johnny Boy (Robert De Niro) and Charlie (Harvey Keitel) were depicted from his trouble-making uncle, who fascinated him, and his hard-working father, his main male reference. Both statements bear truth: in a Decade Under the Influence, what Scorsese is saying is that the film cannot be reduced to an autobiographical exercise - it retains the autonomy that grants it the status of the great piece of art that it is. But no art can be produced without the artist's self-investment in its production and, in this case, Scorsese clearly drew his creative energy from the intense moral conflict he must have lived, growing up in a neighborhood where crime dictated the rules, while in church and at home, the old moral teachings of Catholicism were still the reference. Ultimately, the characters can be seen as two conflicting poles of his own consciousness as he grew up to be a man.

Moral progress and its conflicts are best analyzed through the moral theory of Lawrence Kohlberg. It evolved from his master's Piaget own ideas about the moral evolution of children, which can be summed as a two-stage theory. This was well introduced by W.C. Crain:

Piaget studied many aspects of moral judgment, but most of his findings fit into a two-stage theory. Children younger than 10 or 11 years think about moral dilemmas one way; older children consider them differently. As we have seen, younger children regard rules as fixed and absolute. They believe that rules are handed down by adults or by God and that one cannot change them. The older child's view is more relativistic. He or she understands that it is permissible to change rules if everyone agrees. Rules are not sacred and absolute but are devices which humans use to get along cooperatively. ${ }^{5}$

Kohlberg ${ }^{6}$ proposes a more complex approach, which offers increased insight into the subject. He splits the second stage of Piaget's theory by noticing that relativistic approaches to norms can differ between individualistic and societal. As children can understand norms to be believed by some but disregarded by others, 
while still lacking the understanding of norms as part of a social project, they remain at a pre-conventional realm (that comprises two stages). The entrance into the conventional level with a stage 3 unfolds a world of moral achievements that Piaget had ignored. At that stage, actions are not just followed to please others or avoid punishment as in 1, or to obtain some sort of selfish strategic gain in cooperation with others, as in 2 . Rather, stage 3 is called conventional because norms and principles start being recognized in their permanent nature, as institutions of human society. Kohlberg devised further progress and eventually conceived a post-conventional level that aims at universal principles.

Aside some minor criticism, Kohlberg's theory, much grounded in Kantian principles, is widely accepted and sets the standards in pedagogical science. It was also the focus of a collaborative dialog between Jürgen Habermas and Karl-Otto Apel regarding the possibility of a seventh and final stage - that of an abstract understanding of the idea of humanity. ${ }^{7}$ Even if considered very superficially as done here, Kohlberg's theory is helpful in setting the frame for the interpretation of the characters of Mean Street. The way Charlie and Johnny Boy are introduced is most revealing. Introduced needs to be emphasized as, indeed, before any action specific to the plot, a scene is dedicated to each of the characters. From the introduction on, the spectator is bound to follow them.

Charlie is introduced first. He awakes from sleep, sits up in bed and his face is reflected in a mirror, thoughts echoing in his mind. Raising, mirror, and echo: the sequence is unequivocal about its symbolic meaning. We shall follow and suffer the dwelling of this awakened, self-debating consciousness, as it wanders in the mean streets seeking redemption. In contrast to the steady, solemn environment of Charlie's introduction, Johnny Boy is presented in a dynamic outdoor scene. He is not parted from the street, not allowed Charlie's reflective distance. He is in the streets, acting accordingly to his nickname: the scene shows Johnny placing a firecracker in a newspaper box, and running away, smiling. The spectator who smiles with him has not captured the essence of the film - rather, has not been captured by it. For Johnny's childish behavior is just as serious as Charlie's gloomy expression. Nothing good is to be anticipated for him and is fate seems set from the start, tension building from his idiotic disregard of his debt to Michael. Charlie warns him: 'You give your word about something, you got to keep it'. But he consistently breaks conventional rules - even if those are set by mafia rather than legal code. The Mafiosi context is here irrelevant: the debt stands for the basic conventional norm of respect for word agreements. In that word must be kept lays the primal foundation of Law - pacta sunt servanda - it is the fundamental ingredient of social cohesion that Johnny Boy, driven by his regressive denial of society's boundaries, carelessly disrespects. As he insists in acting as if in a playground, committed only to his close friends, pushing them away when they become too annoying, Johnny is depicted as an isolated soul. Johnny's loud conviviality with friends cannot disguise, but rather highlights, his radical 
loneliness. Trapped in the pre-conventional stage, he has no access to the social world - Arendt's public sphere - he is alienated from any experience of community, deprived from a truly human existence. In the scene at the cemetery, as Charlie urges him to get a job and have a wage, uselessly insisting on giving him advices, Johnny lays back over a grave. Charlie's words are meaningless to him, he is out of reach. It is as if he was already dead.

Johnny loneliness is not limited to his detachment from the social world, it is twofold: he is also lonely in the Arendtian sense ${ }^{8}$ that he lacks an inner voice to talk to; the inner dialogs of consciousness are unknown to him. It would thus be wrong to read Johnny's open confrontation with Michael, in the cathartic scene at the bar, as a proof of his bad intentions. Rather, it is a self-affirmative response to the frustration of being pushed around all the time for this incomprehensible importance everyone else gives to that debt thing. Johnny is simply unconscious about the moral implications of his deeds and, therefore, he is without guilt. That is why we cannot blame him.

Charlie's character lies in the fringe of a different border. He is bent by an inner tension, divided between his loyalties to his Mafiosi ties, and an inner call for something higher. Following his uncle's instructions to collect dubious debts and extort, to be violent or even kill, stands as conventional. These are part of the rules where he comes from. But Charlie's heart is unsettled and Scorsese in unambiguous in the religious nature of his call: from the priest's prologue to his prayers and the cross he carries over his chest. As much as Catholicism can be seen as a set of core values that keep communities together, this conventional role is not to overshadow the far more ambitious aim of Christian morality. The essence of Catholic faith can only be the realization of a post-conventional moral stage, something that is demonstrated, with no requirement for further argument, by the Scripture's episode of Christ turning the other cheek.

In a dialogue between him and Theresa by a peer, Charlie insists in the importance of helping other people - that is, compassion. 'Nobody wants to help anymore', he regrets. The conclusion only enhances the solitary nature of his spiritual dwelling. It is compassion, not friendship, which keeps him close to Johnny; he becomes protective of him as he perceives him as innocent, weak. Alas, Martin Scorsese's second film, and one of his best, is not to be reduced to a lesson of catechesis. Scorsese, who initially considered priesthood, knows better than that. Charlie's last lines, after the final dramatic events, have him repeat 'I'm trying, I'm trying'. When entering the post-conventional stage, where judgment properly becomes ethical, there's not much left than keeping on trying. But Charlie's frustration shows he's no quite there yet.

One senses in Charlie a sort of desperate impatience to find what his soul seeks for. As he inflicts himself pain through burning, it shows how ardently he wishes to set is soul free - and how is aspiration is undermined by obsession. His protection of Johnny falls under this obsession, which it is not entirely sound (according to 
Catholic wisdom, sin chases the sinner all along the way). The confrontational scene at the bar is not cathartic only for Johnny; it is the turning point of the story and arguably its most important scene. After Michael was publicly dishonored and vengeance was sure to strike later, through the innocent lips of Johnny Boy a sentence is dropped to Charlie: 'now you've got what you wanted'. This is said in a rather low tone, and the sequence is cut just as the last ' $\mathrm{d}$ ' is pronounced. It looks almost a technical fault, but indeed the sentence is intended to be subliminal, as if telling a secret.

\section{Notes}

${ }^{1}$ H. Arendt, The Human Condition, The University of Chicago Press, Chicago, 1958.

${ }^{2}$ H. Arendt, Responsibility and Judgement, Schocken, New York, 2003, pp. 89-94.

${ }^{3}$ He does seem to retain Arendt's idea of home as refuge: Charlie longs for a family life with Theresa once he 'deals' with the streets and manages to overcome them.

${ }^{4}$ A Decade Under the Influence, Constant Communication, Writen in Stone, USA, 2003.

${ }^{5}$ W.C. Crain, Theories of Development, Prentice-Hall, Hemel Hempstead, 1985, pp. 118-136.

${ }^{6}$ Kohlberg philosophical works are collected in L. Kohlberg, Essays on Moral Development, Vol. I: The Philosophy of Moral Development, Harper \& Row, San Francisco, 1981.

${ }^{7}$ For the developments of this debate, which falls off the purpose of the chapter, see: K.O. Apel, The Response of Discourse Ethics, Peteers, Leuven, 2001; J. Habermas, Moral Consciousness and Communicative Action, MIT Press, Cambridge 1990.

${ }^{8}$ H. Arendt, Responsibility and Judgement, 2003, pp. 96-100.

\section{Bibliography}

Apel, K.O., The Response of Discourse Ethics. Peteers, Leuven, 2001.

Arendt, H., The Human Condition. The University of Chicago Press, Chicago, 1958.

—, Responsibility and Judgement. Schocken, New York, 2003.

Crain, W.C., Theories of Development. Prentice-Hall, Hemel/Hempstead, 1985. 
Demme, T. \& LaGravanese, R, (dirs), A Decade Under the Influence. Constant Communication, Writen in Stone, USA, 2003.

Habermas, J., Moral Consciousness and Communicative Action. MIT Press, Cambridge 1990.

Kohlberg, L., Essays on Moral Development, Vol. I: The Philosophy of Moral Development. Harper \& Row, San Francisco, 1981.

David Sousa is a researcher at the Centre of Philosophy of the University of Lisbon. 


\section{PART VII}

\section{Futuristic Villains and Cosmic Killers}





\title{
The Mad Scientist as a Villain: H.G. Wells' The Island of Dr. Moreau
}

\author{
Oya Bayıltmış
}

\begin{abstract}
The concept of 'villain' has changed throughout history as a result of the accepted norms and this change has been directly reflected in the literature. In the Victorian age, the reflection of this can be observed in the works of science fiction. This age experienced great developments in science and Darwin's ideas on the evolution of man can be accepted as the peak of this development. The impact of these can be observed in H.G. Wells' The Island of Dr. Moreau. Wells presents the mad scientist, Moreau, as the villain who himself is the slave of science. Moreau creates his 'kingdom' of 'Beast People' on the island and acts like a 'god.' However, he ends up being just the representation of the abuse of scientific knowledge. This influences not only Moreau himself, but also the other people that have no way to leave the island. The most shocking and villainous impact of Moreau's actions, however, is on the animals of the island. He leads to the creation of different types of creatures through vivisection as application of evolution theories. Thus, Wells presents the villainous mad scientist as ruling not only human beings but also the animals with the pretentious aim of scientific experimentation. Moreover, Moreau also leads the other people around him to the verge of madness; e.g. Prendick who would never get rid of the psychological impacts of the time that he has to spend with Moreau. In line with these observations, the aim of my chapter is to analyse the presentation of the villain as a product of science in Wells' The Island of Dr. Moreau, and the inevitable fate of madness as a result of such kind of villainy.
\end{abstract}

Key Words: H. G. Wells, Darwin, evolution theories, manipulation of science, vivisection of animals.

$* * * * *$

The Victorian age was an era of significant social, technological, economic and scientific advancements, which are also reflected in the literature of the period, especially in fictional writings, which were socially realistic. Science fiction, which, as a matter of fact, began to develop in the Victorian age, also mirrors the times. A good, if not the best example for this is Wells' The Island of Dr. Moreau ${ }^{1}$ (1896). Wells deals with the Darwinian theory of evolution and its impacts on the people of the age. ${ }^{2}$ He presents the idea that science, in this case evolutionary theories, can be manipulated by villainous mad scientists and may have negative impacts not only on the scientists themselves but also on the other people around and the wild life. In line with these observations, the aim of my chapter is to analyse the representation of the scientist as a villain who abuses Darwinian 
theory, and to show that Wells creates a kind of dystopia to criticize the attitude of the villainous scientist that leads to both human and wild life destruction. ${ }^{3}$

Actually, as Parrinder notes, The Island of Dr. Moreau's 'outbursts of pain and despair elicited an overwhelmingly hostile press reaction at the time of first publication'. The book was not appreciated when it was published, because at that time the tide of public opinion was fully in favour of scientific research. ${ }^{5}$ The most important development was Darwin's theory of evolution had attracted much attention and all kinds of scientific developments were enthusiastically supported. ${ }^{6}$ So, the book has been regarded to be, as Foot states, 'Swiftian' with its harsh criticism of scientific experiments and it was the 'ferocity' of the book that drew so much criticism. ${ }^{7}$ However, as Renzi indicates, with the two film adaptations, the first by Don Taylor in 1977 entitled The Island of Dr. Moreau and the second by Erle C. Kenton in 1993 entitled Island of Lost Souls, the book gained the deserved attention. ${ }^{8}$ Actually, the ideas on the book ranged from good to bad. As Murray notes, while W. T. Stead, for example, called The Island of Dr. Moreau a book 'which ought never to have been written', ${ }^{9}$ Wells indicated that it is 'the best work I have done' as Bergonzi notes. ${ }^{10}$ Wells himself favoured the book over his other books which support and glorify scientific research.

Before analysing the novel in detail, some background information on the social and historical context of the novel in relation to scientific developments is needed. In fact, as Coren notes, '[t]he London of 1884 was a cornucopian city. It was a period of apparently limitless urban expansion' and Wells himself was just in the middle of this expansion. ${ }^{11} \mathrm{He}$ was aware of the conflict raised by the evolutionary theories. As Suvin comments, he believed that Darwin's theory of evolution had two sides, bright and dark. ${ }^{12}$ Thus, he created a kind of ambiguity in his attitude towards scientific developments. This is highly related to the fact that Wells was the student of Huxley who did not share Darwin's ideas on evolution as reflected in Evolution and Ethics. As Parrinder states, in this specific work, Huxley 'argues that it is only the prospect of subjugating nature through technology which stands between modern humanity and [...] the ancient Stoics and Hindu philosophers'. ${ }^{13}$ Huxley does not support technology and scientific developments when they come to take control over nature. This would just put a distance between the modern man of science and nature. This oppositional attitude of Huxley had an impact on Wells as reflected through his narrator Prendick who is sometimes associated with Huxley. ${ }^{14}$ Actually, this association is historically true since Huxley had delivered Evolution and Ethics just three years before the publication of The Island of Dr. Moreau. Huxley presented controversial dilemmas about the ethics of evolutionary theories. Most important of all, as Bergonzi notes, '[f]or Huxley, Nature, as manifested in evolutionary processes, was cruel and arbitrary, and ethical progress could only be made in opposition to it ${ }^{15}$ which can be easily observed in the attitude of villainous Moreau towards the vivisected animals. ${ }^{16}$ This justifies Prendick's opposing attitude especially when he had the chance to 
observe Moreau's vivisection experiments closely. Prendick's horror of Moreau's vivisection of the animals is directly associated with Wells' questioning mind about contemporary science. Turning back to the impact of Darwin's evolutionary theories, it created not only a biological and social uncertainty but also a theological uncertainty, which shattered the humanistic ideals that placed the man in the centre of the universe. The scientific developments were the ones to come to the fore and the new master turned out to be the man of science. However, there was one problem: the decreasing importance given to human life led to the enslavement of humans to science. Darwin's evolutionary theories added to this overall atmosphere. Moreover, as Parrinder notes, '[ $t]$ he theory of natural selection derives from the Malthusian view of life as a remorselessly competitive struggle for existence' and puts forward the idea that '[e]volutionary 'progress', whether or not it moves towards perfection, depends on the premature dying-out of the majority. ${ }^{17}$

While evolutionary theory seems to be positive in terms of human development, it can turn negative if the idea of survival of the fittest is added to this idea of painful evolution. The extent of suffering becomes clearer with the extent of the destruction of the unfitting ones. Due to the reflections of the suffering during the process of evolution, as Coren argues, it would not be wrong to call The Island of Dr. Moreau as a horror story. ${ }^{18}$ However, the most horrifying aspect of the book is that Moreau becomes the villain who is a slave of science. Moreau explains his ideas about evolutionary theories and vivisection as follows:

[...] I went on with this research just the way it led me. That is the only way I ever heard of research going. I asked a question, devised some method of getting an answer, and got - a fresh question. Was this possible, or that possible? You cannot imagine what this means to an investigator, what an intellectual passion grows upon him. You cannot imagine the strange colourless delight of these intellectual desires. The thing before you is no longer an animal, a fellow-creature, but a problem. Sympathetic pain - all I know of it I remember as a thing I used to suffer from years ago. [...] To this day I have never troubled about the ethics of the matter. The study of Nature makes a man at last as remorseless as Nature. ${ }^{19}$

Yet, all this so-called scientific passion of Moreau is considered to be just 'an abomination' by Prendick. ${ }^{20}$ Moreover, if it is remembered that the book deals with theological uncertainty as a result of the evolutionary theories, Moreau comes to the fore as a satirical representation of God. He gives them life as human beings through a torturing system but also, as Murray notes, when he discovers that they cannot leave their bestial qualities he just wants them to die. ${ }^{21}$ Moreau becomes the 
total source of pain on the island and, as Bergonzi states, appears to be "not only a nightmarish caricature of the Almighty: he can also be seen as a hypostatized image of the pretensions of science'. ${ }^{22}$ Moreau becomes just a parody of God and gives his creations the laws ${ }^{23}$ which are also the parodies of the laws in the Bible. ${ }^{24}$ Consequently, as Suvin notes, Moreau appears as 'not only a latter-day Dr. Frankenstein but also a demonically inverted God of Genesis'. ${ }^{25}$ Although he is a devoted man of science, his experiments lead to the suffering of the animals on the island. He experiments on the animals regardless of what the vivisected animals experience afterwards.

Moreover, Moreau does not at all regard the human beings on the island as important or valuable. Montgomery is like a mute man and never questions Moreau and his attitude towards the animals. He just wants to continue his life on the island as he has no place in the society if he is made to return. Prendick is another captive of Moreau who cannot prevent Moreau's villainous experiments and ends in a state of psychological disturbance. In this respect, as Smith notes, although Wells 'had a sense of the purity of science [...] received from Huxley,' The Island of Dr. Moreau presents 'vicious attacks from the centre of the scientific community on bad science, unethical science, science which is not only pure, but ultimately evil'. ${ }^{26}$ Moreau presents himself as equal to God and indicates that

[...] It may be I fancy I have seen more of the ways of this world's Maker than you - for I have sought his laws, in my way, all my life, while you, I understand, have been collecting butterflies. ${ }^{27}$

Prendick defines Moreau's such kind of attitude as a 'kind of deification of himself' while Moreau himself defines this as desire for '[a] humanising process ${ }^{28}$ It is apparent that Wells presents a demonic scientist who is to control life on island which can be taken as 'a biological research station owned by [...] Dr. Moreau,' as Smith notes, ${ }^{29}$ or 'a zoological laboratory', ${ }^{30}$ as Borrello notes. Moreau represents himself as a devoted man of science and claims to have done whatever he did for the sake of science. Moreover, as Draper states, Moreau has convinced himself that his 'goal is a heroic one, to create a more rational race, less subject to their physical sensations'. ${ }^{31}$ However, as Renzi argues, his villainous experiments on the animals and their suffering due to vivisection reveal Moreau just a mere egocentric and ambitious man. ${ }^{32}$ What he wants is just to create an evolution regardless of the actual results. He acts single-mindedly as a slave to his own evil theories. This can be easily understood from his sadist aim to create a more rational race out of animals. However, as Bergonzi notes, Moreau's experiments, first and foremost, disappoint him as '[n]one of his investigators returns without wounds and bruises to the mind as well as the body' which leads him to be associated with 'a wounded man who has had a sight of sadism and 
death' ${ }^{33}$ Likewise, Wells appears as a novelist who is disappointed by the disasters created by the manipulation of science. Moreau's irresponsible experimentations on animals bring him to the verge of villainy, which constitutes, as Smith indicates, Wells' 'most sardonic attack and assault on science without thought [...] [through] a scientist without ethics'. ${ }^{34}$

It is also important that Wells depicts the binary opposition between culture/science and nature. The dichotomy between Moreau and the puma is very important as a reflection of this opposition. Although he regards himself as a devoted man of science, as Hammond notes,

Moreau with his indifference to pain, his inhumanity, his obsession with his research to the exclusion of all other considerations, symbolises the emptiness of knowledge without compassion. He is the steely man of science: stoical, unemotional, obdurate. The puma represents the opposite values: wildness, feeling, energy, animality. ${ }^{35}$

He even does not take the puma as a living entity but just a 'new stuff' for his vivisection. ${ }^{36}$ Yet, Prendick feels pity for the puma. At first, as Borrello notes, Prendick is influenced by the devotion of Moreau to science. ${ }^{37}$ Prendick sees what Moreau has stated: 'the possibilities of vivisection do not stop at a mere physical metamorphosis' ${ }^{38}$ However, he realizes the physical and psychological pain he gives to the vivisected animals later. As McConnell states, Moreau ignores the ethical part in his experiments by reducing 'the idea of suffering - and [...] of human sympathy - to a cosmic irrelevance', ${ }^{39}$ he is torn between his failing experiments ${ }^{40}$ and his desire ${ }^{41}$ to create a better race. This idea proves, as Suvin indicates, '[s]cience is the true, demonic master of all the sorcerer's apprentices in Wells, who have - like Frankenstein or certain folktale characters - revealed and brought about destructive powers and monsters'. ${ }^{42}$ Moreau creates in-betweenness, a state between humanity and bestiality which brought death to him. He only gave birth to a destructive power within the vivisected animals, which do not know how to control this unnatural power. Furthermore, as Hillegas argues, 'Moreau is a far more sinister creature than the medieval Faust or Mary Shelley's Frankenstein. He has Huxley's intelligence, knowledge, and command of the powerful scientific method' while 'he does not have Huxley's controlling humanity' and so 'Moreau's activities foreshadow anti-utopian nightmare states whose rulers, free of all ethical considerations, employ biological, chemical, and psychological conditioning and manipulation in order to maintain total control over their citizens' ${ }^{43}$ It is he who is the slave of science and who becomes the creator of a dystopia based on evil science. His main aim is to gain control over human and animal life rather than pure science. He abuses his scientific knowledge and creates a world of his own, 
while ignoring all ethical concerns and creating a number of different kinds of species through vivisection.

Moreover, as Bergonzi notes, 'science is radically changing the human environment ${ }^{44}$ not only for the animals but also for the other humans on island: Prendick and Montgomery. Montgomery had spent eleven years facing the results of Moreau's villainous experiments and came to feel a kind of sympathy for the vivisected animals. Prendick realizes that Montgomery 'had been with them so long that he had come to regard them as almost normal human beings - his London days seemed a glorious impossible past to him ${ }^{45}$ When Prendick advices him to return to London, he feels sorry in that '[w]hat is the good of getting away? I'm an outcast. Where am $I$ to join on?'. ${ }^{46}$ Montgomery has almost begun to feel like one of the Beast people. ${ }^{47}$ Prendick also experiences a kind of psychological shock when he returns in that, as Kemp states, '[n]ot surprisingly, once back in London, he prefers to skulk behind locked doors rather than brave the streets'. ${ }^{48} \mathrm{He}$ experiences a psychological downfall as he loses his hopes in humanity the reason of which can be associated with both the inhuman Moreau and the vivisected animals that are forced to behave like man. Moreau teaches them to speak and walk, but at the end they cannot help turning back to their bestial origins. Experiencing all these, Prendick feels 'no desire to return to mankind'. ${ }^{49}$ After returning to England, as Hammond notes, 'he cannot bring himself to admit that there is any fundamental difference between the seeming men and women about him and the Beast Folk ${ }^{50}$ and he would handle the problem just thanks to the help of a mental specialist. ${ }^{51}$ Wells's aim is to show that scientific research may become, as Renzi argues, 'destructive and parasitic when it violates natural laws and lacks practical applications'. ${ }^{52}$ Moreau has extensive information of science, but he just abuses them and creates a science of his own adorned with his own ambition without any ethical concern. Thus, as Renzi notes, '[s]cience must know its limitations. It becomes irresponsible when researchers, like Moreau, put knowledge ahead of practical applications ${ }^{53}$ Representing such kind of a dystopia, Wells criticizes the evil side of science that can be manipulated by the villainous scientists. As Hammond comments, man is adorned with a 'vast potential for good or evil' and it is just a matter of choice. ${ }^{54}$

To conclude, it can be suggested that Wells presents the mad scientist as a villain in his The Island of Dr. Moreau to prove the idea that man should know his limits even if he is a scientist. Only then can all kinds of torture for all living beings be prevented. Otherwise, any kind of scientific developments might not add much to human development, and the scientific experiments might result in mere acts of atrocious villainy. 


\section{Notes}

1 As Murray notes, the term 'science fiction' was coined in 1926 by Hugo Gernsback and it was Jules Verne who was the founder of modern science fiction with his Journey to the Center of the Earth (1864) and From the Earth to the Moon (1865). B. Murray, H. G. Wells, Continuum, New York, 1990, p. 86.

${ }^{2}$ As Suvin notes, Wells's 'first and most significant SF cycle (roughly to 1904) is based on the vision of a horrible novum as the evolutionary sociobiological prospect for mankind'. The Island of Dr. Moreau belongs to this cycle and is interpreted by some critics as a representation of social Darwinism as well. D. Suvin, 'Wells as the Turning Point of the SF Tradition' Critical Essays on H. G. Wells, J. Huntington (ed), G. K. Hall \& Co., Boston, 1991, p. 23.

${ }^{3}$ Actually, as Hammond notes, "[t]hat Wells had a more serious, didactic intent is shown by the fact he originally proposed as its subtitle $A$ Satire or A Satirical Grotesque'. J.R. Hammond, An H. G. Wells Companion: A Guide to the Novels, Romances and Short Stories, Macmillan, London, 1979, p. 85.

${ }^{4}$ P. Parrinder, Shadows of the Future: H.G. Wells, Science Fiction and Prophecy, Syracuse UP, New York, 1995, p. 63.

${ }^{5}$ As Bergonzi notes, the novel was regarded to be 'a very pessimistic book'. B. Bergonzi, H.G. Wells: A Collection of Critical Essays, Prentice-Hall, Inc., New Jersey, 1976, pp. 32-33.

${ }^{6}$ As McConnell indicates, Darwin turned romantic impacts of evolution into postromantic certainties by erasing the line between man and animal. Thus, he questioned the position of an in life. F. McConnell, The Science Fiction of H.G. Wells, Oxford UP, New York, 1981, p. 94.

${ }^{7}$ M. Foot, H.G.: The History of Mr. Wells, Counterpoint, Washington, 1995, p. 36.

8 C.T. Renzi, H.G. Wells: Six Scientific Romances Adapted For Film, The Scarecrow Press, New Jersey, 1992, p. 60.

${ }^{9}$ Murray, p. 94.

${ }^{10}$ B. Bergonzi, 'The Early H.G. Wells', The Critical Response to H. G. Wells, W.J. Scheick (ed), Greenwood Press, London, 1995, p. 26.

${ }^{11}$ M. Coren, The Invisible Man: The Life and Liberties of H.G. Wells, Atheneum, New York, 1993, p. 37.

${ }^{12}$ Suvin, op. cit., p. 25.

${ }^{13}$ Parrinder, op. cit., p. 52.

${ }^{14}$ Prendick affirms this association by saying Moreau that ' $I$ had spent some years at the Royal College of Science, and had done some research in biology under Huxley'. H.G. Wells, The Island of Dr. Moreau, Bantam Dell, New York, 2005, p. 26.

${ }^{15}$ Bergonzi, 'The Early H. G. Wells', The Critical Response to H. G. Wells, p. 28. 
16 As Smith notes, Moreau just ends up with fusing 'animals into parodies of human beings' rather than humanising them. D.C. Smith, H.G. Wells Desperately Mortal: A Biography, Yale UP, New Haven, 1986, p. 61.

${ }^{17}$ Parrinder, op. cit., p. 51.

${ }^{18}$ Coren, op. cit., p. 54.

${ }^{19}$ Wells, op. cit., p. 78.

${ }^{20}$ Ibid., p. 78.

${ }^{21}$ Murray, op. cit., p. 92.

${ }^{22}$ Bergonzi, 'The Early H.G. Wells', p. 27.

${ }^{23}$ As Smith notes, this is just a 'parodic version of Kipling's 'Law of the Jungle'. Smith, op. cit., p. 61.

${ }^{24}$ These laws are:

'Not to go on all-Fours; that is the Law. Are we not Men?'

'Not to suck up Drink; that is the Law. Are we not Men?'

'Not to eat Flesh or Fish; that is the Law. Are we not Men?'

'Not to claw Bark of Trees; that is the Law. Are we not Men?'

'Not to chase other Men; that is the Law. Are we not Men?'

The Island of Dr. Moreau, p. 61.

${ }^{25}$ Suvin, op. cit., p. 27.

${ }^{26}$ Smith, op. cit., p. 57.

${ }^{27}$ Wells, op. cit., p. 77.

${ }^{28}$ Moreau teaches the Beast People that:

'His is the House of Pain.'

His is the Hand that makes.'

'His is the Hand that wounds.

'His is the Hand that heals.'

[...]

'His is the lightening-fresh' [...]

'His is the deep salt sea'

Wells, op. cit., p. 61.

${ }^{29}$ Smith, op. cit., p. 60.

30 A Borrello, H.G. Wells: Author in Agony, Southern Illinois UP, Carbondale, 1972, p. 56.

${ }^{31}$ M. Draper, Modern Novelists: H. G. Wells, Macmillan, London, 1987, p. 45.

${ }^{32}$ Renzi, op. cit., p. 64.

${ }^{33}$ Bergonzi, H.G. Wells, op. cit., p. 35.

${ }^{34}$ Smith, op. cit., p. 60.

35 J.R. Hammond, H.G. Wells and Rebecca West, Harvester Wheatsheaf, Hertfordshire, 1991, p. 77

${ }^{36}$ Moreover, in this respect, as Parrinder asserts, if Dr. Moreau is accepted as a parodic representation of God, his vivisection experiments can be taken as a 
parody of white man's burden in that as a white European his desire is to civilise the beasts. Parrinder, p. 57.

37 A Borrello, H.G. Wells: Author in Agony, Southern Illinois UP, Carbondale, 1972, p. 57.

${ }^{38}$ Wells, op. cit., pp. 75-76.

${ }^{39}$ McConnell, op. cit., p. 91.

40 Moreau shows his disappointment by saying that '[s]o for twenty years altogether - counting nine years in England - I have been going on, and there is still something in everything I do that defeats me, makes me dissatisfied, challenges me to further effort'. Wells, op. cit., p. 80-81.

${ }^{41}$ As McConnell notes, Moreau wanted to take control over the evolution, which is just a reflection of sadism and makes the island almost a concentration camp. McConnell, op. cit., p. 92.

${ }^{42}$ Suvin, op. cit., p. 24.

${ }^{43}$ M.R. Hillegas, The Future as Nightmare: H. G. Wells and the Anti-utopians, Southern Illinois UP., Carbondale, 1967, p. 37.

${ }^{44}$ Bergonzi, H.G. Wells, p. 32.

${ }^{45}$ Wells, op. cit., p. 86.

${ }^{46}$ Ibid., p. 111.

${ }^{47}$ Ibid., pp. 81-82.

${ }^{48}$ P. Kemp, H.G. Wells and the Culminating Ape: Biological Imperatives and Imaginative Obsessions, Macmillan, London, 1996, p. 22.

${ }^{49}$ Wells, op. cit., pp. 81-82.

${ }^{50}$ Hammond, An H.G. Wells Companion, p. 86.

${ }^{51}$ The Island of Dr. Moreau, p. 138.

${ }^{52}$ Renzi, op. cit., p. 62.

${ }^{53}$ Ibid., p. 24.

${ }^{54}$ Hammond, An H.G. Wells Companion, op. cit., p. 87.

\section{Bibliography}

Bergonzi, B., H.G. Wells: A Collection of Critical Essays. Prentice-Hall, Inc., New Jersey, 1976.

—, 'The Early H.G. Wells'. The Critical Response to H.G. Wells. Scheick, W.J. (ed), Greenwood Press, London, 1995.

Borrello, A., H.G. Wells: Author in Agony. Southern Illinois UP, Carbondale, 1972. 
Coren, M., The Invisible Man: The Life and Liberties of H.G. Wells. Atheneum, New York, 1993.

Draper, M., Modern Novelists: H. G. Wells. Macmillan, London, 1987.

Foot, M., H G.: The History of Mr. Wells. Counterpoint, Washington, 1995.

Hammond, J.R., H.G. Wells and Rebecca West. Harvester Wheatsheaf, Hertfordshire, 1991.

—, An H.G. Wells Companion: A Guide to the Novels, Romances and Short Stories. Macmillan, London, 1979.

Hillegas, M.R., The Future as Nightmare: H.G. Wells and the Anti-Utopians. Southern Illinois UP., Carbondale, 1967.

Kemp, P., H.G. Wells and the Culminating Ape: Biological Imperatives and Imaginative Obsessions. Macmillan, London, 1996.

McConnell, F., The Science Fiction of H.G. Wells. Oxford UP, New York, 1981.

Murray, B., H.G. Wells. Continuum, New York, 1990.

Parrinder, P., Shadows of the Future: H.G. Wells, Science Fiction and Prophecy. Syracuse UP, New York, 1995.

Renzi, T.C., H.G. Wells: Six Scientific Romances Adapted For Film. The Scarecrow Press, Inc., New Jersey, 1992.

Smith, D.C., H.G. Wells Desperately Mortal: A Biography. Yale UP, New Haven, 1986.

Suvin, D., 'Wells as the Turning Point of the SF Tradition'. Critical Essays on H. G. Wells. Huntington, J. (ed), G. K. Hall \& Co., Boston, 1991.

Wells, H.G., The Island of Dr. Moreau. Bantam Dell, New York, 2005.

Oya Bayıltmış is a research assistant and a Ph.D. student in the Department of English Language and Literature at Hacettepe University, Ankara, Turkey. She received her BA in 2008 from the same department. Her main interests are the British novel, colonial and postcolonial studies, literary and cultural theories. 


\title{
I Am the Man in the Dark Room: The Puppetmaster from Cosmic Adversary to Cosmic Villain
}

\author{
Luke Seaber
}

\begin{abstract}
This chapter focuses on the 'puppetmaster' villain: that is, one who is in fact organizing both sides of a struggle for their own ends. I shall suggest that one of the most productive sources for this figure is Sunday in Chesterton's The Man Who Was Thursday (1908). I wish to examine two figures inspired by Sunday, O'Brien in Nineteen Eighty-Four (1949) and the Architect in the Wachowski brothers' film, The Matrix Reloaded (2003), and one situation (in which the villain of the piece remains hidden), that of Terry Pratchett and Neil Gaiman's Good Omens (1990). It will be argued that the puppetmaster figure in these works comes out of a highly productive misreading of Chesterton. Whereas Sunday is an adversary in The Man Who Was Thursday, he is eventually revealed not to be a villain. I shall explore how successive misreadings transformed a figure that Chesterton ultimately intended to be understood as representing Nature and, behind the mask of Nature, God into representations of evil. O'Brien and the Architect, although differing greatly in aims and characterizations, both share Sunday's puppetmaster role, yet use their plotting to entrap the hero into a course of action meant to lead to the hero's downfall. Chesterton's Christian puppetmaster is Gnosticized into an evil demiurge. In Good Omens, however, we find a more generalized misreading in which the absolutes of Evil and Good are collapsed, as it were, into an overarching non-humanity contrasted with humanity and its mixture of good and evil. The concept of the negative and positive poles of the cosmos being in fact equivalent to each other is explicitly stated to be something recognized by Chesterton. It will be explored how this misreading is in itself a greater distortion of Chesterton's work than that practised by Orwell or the Wachowskis yet nonetheless has an ideological message nearer to Chesterton's.
\end{abstract}

Key Words: Chesterton, Orwell, Matrix, Pratchett, Gaiman, good, evil, free will.

$* * * * *$

The idea of the 'hidden' criminal is fundamental to discussions of twentiethcentury representations of villainy in genre fiction. In any whodunit, for example, it is of course the discovery of the hidden murderer that makes the genre. If we move away from the whodunit and towards the thriller, and the spy thriller especially, then we may conclude that within any context of opposing power blocs (and herein, perhaps, the true difference between the thriller and the whodunit may be sought) it is much more likely that the target of the search for the villain is a traitor rather than any other sort of criminal. If the traitor is high enough in the 
organization nominally served, then (almost by necessity) they must finish by manoeuvring their supposed allies in the interests of their true masters. Following on from this, if they are also high enough in the organisation that they really serve, then we may describe them as manoeuvring both sides for their own ends. We have, therefore, the basic form of what I wish to call here the 'puppetmaster' villain: a hidden figure controlling both sides in a conflict. However, I do not wish to examine here this basic figure, which, after all, is only what one would suppose to be a reasonably accurate portrayal of the situation of a real-life highly-placed double agent. I rather wish to examine a series of figures moving beyond the merely mimetical and into a realm of cosmic importance: a geneology of adversarial figures (and not solely villains) beginning with G.K. Chesterton's Sunday, figures that not only control both sides of a conflict but also create them.

Sunday is the key figure - although emphatically not the protagonist ${ }^{1}$ - in Chesterton's 1907 novel, The Man Who Was Thursday. In the novel, Gabriel Syme, seemingly merely a poet and intellectual supporter of order, talks his way into being taken to a meeting of a group of anarchist terrorists by Lucian Gregory, an anarchist poet. Once there he convinces the meeting to elect him as Thursday to the ruling seven-member Central Anarchist Council, or Council of Days, the members of which take the names of the days of the week. It is then revealed that Syme is a police detective vowed to the defeat of the anarchists. He has been sworn in as a member of the anti-anarchist detectives by their head, an unseen figure in a dark room. It soon becomes clear that all the members of the Council are policemen; the exception is the near-superhumanly large and vital President, Sunday. Returning from chaotic and surreal events in France, the detectives confront Sunday. Before he escapes, he stops to tell his pursuers, "I am the man in the dark room, who made you all policemen'. ${ }^{2}$ A chase ensues ending with the detectives being welcomed to a party at Sunday's mansion, where they are dressed in clothes representing the Genesis account of the day after which they are named. The final scene of reveals the events to have been Syme's dream or vision; but before this there is an explanation of why Sunday has created the conflict. The Council of Days is challenged by Gregory, who accuses them of being, in cosmic terms, the Law. He accuses them, and ruling power in general, of being safe: power and authority are wrong in his view because no challenge can touch them; they run no risks and should be overturned because they never have been overturned. Syme replies that he now understands: Sunday's playing both roles means that 'each thing that obeys law may have the glory and isolation of the anrachist'.

The overall 'meaning' of Chesterton's novel I do not wish to discuss here. ${ }^{4}$ Of importance here is the figure of Sunday, simultaneous organizer of the anarchists and the policemen set on destroying them. Chesterton's own description of Sunday as representing 'Nature as distinguished from God' is generally critically accepted. ${ }^{5}$ Of more interest to us here is the structural role of Sunday and his orchestrating the situation providing the whole framework for the novel. 
Chesterton stated that the starting point for the novel was the idea of reversing the standard detective-story theme of the seemingly harmless being villains, having the seemingly harmful revealed as heroes. ${ }^{6}$ We might thus be tempted to dismiss Sunday's dual nature as merely the ultimate example of this reversal. So reductive a reading is possible only if we are unaware of Chesterrton's fullest statement about the nature of Sunday, from the late-1920s interview where he says he represents Nature rather than God. That Sunday is not meant to represent God was often repeated by Chesterton, most notably in the last column he wrote for the Illustrated London News, from 13 June 1936, the day before he died. He claims that taking Sunday as 'a serious description of the Deity' is 'lunacy'. ${ }^{7}$ There is perhaps some disingenuousness here, for we have his word in the aforementioned 1920s interview that, whilst Sunday is not God, nor is he totally removed from a 'description of the Deity': Sunday's last words in the novel are a quotation from Mark 10:38, 'Can ye drink of the cup that I drink of?', and Chesterton says this 'seems to mean that Sunday is God. That is the only serious note in the book, the face of Sunday changes, you tear off the mask of Nature and you find God'.

If we can validly consider Sunday, even if not representing God, as being a qualitatively different type of character from the rest of the Council of Days, what can we conclude about his role within the novel's structure? Perhaps the most fruitful way to look at it is in terms of protagonists. The main body of the narrative starts with one protagonist - Syme - and six antagonists - the Council of Days. Of these, the first revealed as a detective is Tuesday, who then disappears from the narrative until the final chase with all the detectives together. The next revealed is Friday, who becomes Syme's ally: the deuteragonist. Then Saturday, who becomes, as it were, the tritagonist. Then Wednesday reveals himself. With the by now expected revelation that Monday is also a detective and the reappearance of Tuesday, Syme rather loses his centrality in the narrative, which focuses more on group action and less on individual. It will be seen that towards the end of the novel the structure has become the exact opposite of that prevailing when the Council of Days was introduced: we have six protagonists and one antagonist. When Sunday's mansion is reached and the cosmic nature of the plot revealed, relationships change again. We still have six protagonists and one antagonist, but the antagonist is now Gregory, 'the real anarchist'. Structurally, what has Sunday become? Sunday - leader of both anarchists and police, and thus always on the side of both protagonists and antagonists - finally moves explicitly beyond the binary logic of good and evil (not, it should be stressed, the same thing as being beyond good and evil themselves). In truth he has always been so, but it is only now structurally revealed. He steps out, so to speak, of the internal narrative structure, and into the space beyond it: he stands revealed as non-human; as a third force that is neither protagonist good nor antagonist evil. Choosing good or evil for Chesterton is a question of free will; Sunday, and God behind Sunday, is beyond 
this choice: the puppetmaster is able to control both sides because he is beyond them.

This structural complexity, I believe, allowed Chesterton to dramatize questions of free will without having to become over-explicit; the puppetmaster, paradoxically, is necessary here as a source of free will, and indeed perhaps author would be a better metaphor than puppetmaster. ${ }^{9}$ The puppetmaster provides the theatre of action in which moral choices are made.

In the second text under consideration, Nineteen Eighty-Four, the situation changes. Orwell's novel, unlike Chesterton's, is well known enough not to need describing. The puppetmaster figure here is O'Brien, Inner Party member and organizer of the revolutionary movement known as the Brotherhood, which, all the evidence suggests, exists only to entrap those who would overthrow the Party. Sunday's influence on O'Brien, like the influence of The Man Who Was Thursday on Nineteen Eighty-Four is generally accepted critically. ${ }^{10}$ Two points are of interest here. The first (for reasons we shall see when considering the geneology running from The Man Who Was Thursday to The Matrix Reloaded) has to do with imagery connected with O'Brien. Winston describes a dream he once had:

$[\mathrm{H}] \mathrm{e}$ had dreamed that he was walking through a pitch-dark room. And someone sitting to one side of him had said as he passed: 'We shall meet in the place where there is no darkness'. [...T] he identification existed. It was O'Brien who had spoken to him in the dark. ${ }^{11}$

The 'place where there is no darkness' reveals itself to be the cells and torture chambers of the Ministry of Love, where the lights are never turned off and covering one's eyes is forbidden. ${ }^{12}$ The resemblence to Sunday is clear.

The second point of interest is the different use of the puppetmaster made by Orwell. Sunday collapses the hero/villain dichotomy, and is not both, but neither, a third term. This is not true of O'Brien. O'Brien is a villain; he uses his puppetmaster role for the interests of one of the sides in the conflict, the Party's. Although O'Brien is geneologically related to Sunday, the structural use made of the character steps back from the innovation proposed by Chesterton, and returns to a more standard opposition of protagonist and antagonist.

A similar situation may be seen in the second film in the Wachowski brothers' Matrix trilogy, The Matrix Reloaded (2003). The central conceit of the Matrix trilogy is that at some point in the future the world has been taken over by machines using living human bodies as energy sources; the minds of the bodies inhabit a vast computer simulation of reality - the Matrix. A small number of humans have managed to escape the Matrix. Keanu Reeves plays Neo, 'the One', a Messiah-like figure. Theological interpretations of the films abound, ${ }^{13}$ and the fact there is a Sunday figure, the Architect, with a major role in the second film also 
suggests the validity of interpreting the films in a religious light. I remain here, however, interested in the structural role of the Sunday figure. Neo meets the Architect, a sentient computer program, when trying to reach the heart of the Matrix. He learns that the Architect, who designed the Matrix, long ago discovered that a 'perfect' Matrix did not function, and that the only way for it to function was to leave the possibility of a choice, even if only at a subconscious level, to the humans plugged into it. This system leads to the periodic emergence of an anamoly, the One, needed to reset the Matrix. The Neo of the film is in fact the sixth. He is offered the choice of resetting the program and saving humankind or not doing so and allowing it to be destroyed.

The role of the Architect as (indirect) creator of Neo and of the anti-machine revolt as well as of the system Neo is trying to destroy puts him squarely in the Sunday tradition. An example of the film set in which he appears cannot but suggest O'Brien and thus a clear, specific, line of inheritance from Chesterton rather than a merely generic one. The Architect resides in a white-ceiling and floored space walled with monitors: he lives in a world of bright light as opposed to the muted grey-green hues of the rest of the Matrix. Like O'Brien, he is found in a 'place where there is no darkness'. Like O'Brien his structural role still remains within the standard protagonist/antagonist scheme. However, unlike O'Brien but like Sunday, the Architect has a role within the narrative that can fairly be described as cosmic: he is more than just the creator of the localized conflict in which he is puppetmaster. Whereas Sunday is a cosmic character but not a villain and O'Brien is not a cosmic character but is a villain, the Architect is a cosmic villain. Both Sunday and the Architect step outside of the narrative of the work containing them in terms of the degree to which they are a puppetmaster, but the Architect remains tethered in the narrative by his being fundamentally allied with only one side of the conflict taking place within the situation he creates.

The differences in light-based symbolism regarding these three characters correspond to the differences in their narrative roles. Sunday is connected with the dark. It is symbolically in the dark that free will must be exercised; that secrets and choices are possible. O'Brien moves from being associated with the dark to being associated with the light. In a panoptic society like that of Oceania, darkness means not being observed and therefore freedom, and light observation and no freedom. This symbolic movement of O'Brien's, however, also marks his lack of a cosmic role: he changes, even if only symbolically, in a way impossible for the Architect or Sunday. The Architect, meanwhile, is only ever in the light. The Matrix too is a panoptic society, and the Architect must always watch. This means that he is also symbolically unable to move beyond his role as an antagonist.

With Good Omens we come to the final stage so far reached in the genealogy of Chesterton's Sunday. This 1990 novel pre-dates The Matrix Reloaded, but has been to last as its use of the puppetmaster figure represents a far richer reinterpretation than the Architect. Good Omens, written by Terry Pratchett and 
Niel Gaiman, is a parody of the 1976 film The Omen. It details the birth and childhood of the son of Satan, who by mistake is left to grow up with neither angelic nor demonic interference, and thus becomes, as Crowley says, "not Evil Incarnate or Good Incarnate, [but] just ... a human incarnate'. ${ }^{14}$ Two of the chief protagonists - the novel has many - are Crowley and Aziraphale, a demon and angel respectively, both stationed on Earth, where they have to come to be friends and prefer terrestrial life to Heaven or Hell. The book's dedication is to Chesterton, 'A man who knew what was going on', ${ }^{15}$ and Crowley at one point muses that 'Chesterton [was t] he only poet in the twentieth century to come even close to the Truth'. ${ }^{16}$ This 'Truth' is that both sides in the conflict - Heaven and Hell - are so similar as to be indistinguishable. The degree to which this is a misreading of Chesterton's novel is clear: Chesterton is talking about a situation created to allow free will to serve cosmic power without merely being power worship. This only has sense if we allow for the possibility of real good and evil. In this Good Omens misreads Chesterton more than the other two works examined. However, the overall structure of the novel remains closer to Chesterton's work. Although there is no individual Sunday figure in the book, the collected and generally unseen ultimate ruling forces of Heaven and Hell work as a collective Sunday, using the world as battleground where the conflict between good and evil is controlled by the same forces. This collapses the protagonist/antagonist dichotomy and presents a new binary: humanity, comprised of mixed good and evil, and non-humanity, which, whether 'Evil' or 'Good', is a puppetmaster. This shifting of the moral importance onto choosing between good and evil rather than being good is far nearer ideologically to the situation in Chesterton's novel.

We have therefore seen how this genealogy of the puppetmaster starts with a figure not a villain but rather a cosmic manipulator in a context beyond human good and evil. We have seen in Nineteen Eighty-Four and The Matrix Reloaded two interpretations reducing this figure to a villain. Finally, we see a case in which a far greater misreading of the original influence leads to a cosmic puppetmaster collective once again operating in a context beyond human good and evil, with the emphasis shifted to how the worst thing with a cosmic antagonist is quite simply that it is cosmic and therefore removed from humanity, and thus more villainous than any possible human villainy or villains.

\section{Notes}

${ }^{1}$ At least in any standard analysis. As will be seen below, the case can be made that normal analyses of character roles within the structure of the novel are not necessarily sufficient for understanding how it functions.

${ }^{2}$ Ibid., p. 608.

${ }^{3}$ Ibid., p. 634. 
4 See M. Gardner, 'Introduction', The Man Who Was Thursday, M. Gardner (ed), Ignatius, San Francisco, 1999, pp. 9-21 for a sound overview of the novel's themes.

${ }^{5}$ This comment of Chesterton come from an interview almost twenty years after the publication of the novel. M .Ward, Gilbert Keith Chesterton, Rowman and Littlefield, Lanham, 2006 [1944], p. 169.

${ }^{6}$ See, inter alia, Chesterton's introduction to the 1926 dramatization of the novel in the appendix to Gardner's edition cited above, pp. 271-275.

${ }^{7}$ This column is to be found in the appendix to Gardner's edition of The Man Who Was Thursday, pp. 280-281.

${ }^{8}$ Ward, loc. cit.

9 Compare Chesterton's play The Surprise, on the issue of free will: G.K. Chesterton, The Surprise in The Collected Works of G.K. Chesterton, Vol. XI, Ignatius, San Francisco, 1989, pp. 297-343.

${ }^{10}$ For an overview of Chesterton's influence on Nineteen Eighty-Four, see L. Seaber, G.K. Chesterton and George Orwell: A Study in Denied Influence, Edwin Mellen, Lampeter, forthcoming, pp. 97-118 and, with less analysis but various details not mentioned in Seaber, W. Steinhoff, George Orwell and the Origins of 1984, University of Michigan Press, Ann Arbor, 1976, pp. 16-19. For the best specific analysis of the Sunday-O'Brien relationship, see L.C. Burkhardt, 'G.K. Chesterton and Nineteen Eighty-Four', George Orwell, Greenwood, Westport, 1987, pp. 5-10.

${ }^{11}$ G. Orwell, Nineteen Eighty-Four, London, Penguin, 1989 [1949], p. 27.

${ }^{12}$ Ibid., p. 246.

${ }^{13}$ See F. Flannery-Dailey and R. Wagner, 'Wake Up!: Gnosticism and Buddhism in The Matrix', Journal of Religion and Film, 5:2, October 2001; D. Bowman, 'The Gnostic Illusion: Problematic Realized Eschatology in The Matrix Reloaded', Journal of Religion and Popular Culture, 2003; J.R. Fielding, 'Reassessing The Matrix/Reloaded', Journal of Religion and Film, 7:2, October 2003; M.D. Stucky, 'He Is the One: The Matrix Trilogy's Postmodern Movie Messiah', Journal of Religion and Film, October 2005; J. Wittung and D. Bramer, 'From Superman to Brahman: The Religious Shift of The Matrix Mythology', Journal of Religion and Film, 10:2, October 2006.

${ }^{14}$ T. Pratchett and N. Gaiman, Good Omens, Corgi, London, 1991 [1990], p. 353.

${ }^{15}$ Ibid., unnumbered dedication page.

${ }^{16}$ Ibid., p. 270.

\section{Bibliography}

Bowman D., 'The Gnostic Illusion: Problematic Realized Eschatology in The Matrix Reloaded'. Journal of Religion and Popular Culture. 2003. 
Burkhardt, L.C., 'G.K. Chesterton and Nineteen Eighty-Four'. George Orwell, Greenwood, Westport, 1987.

Chesterton, G.K., The Surprise in The Collected Works of G.K. Chesterton, Vol. XI, Ignatius, San Francisco, 1989, pp. 297-343.

Fielding, J.R., 'Reassessing The Matrix/Reloaded'. Journal of Religion and Film, Vol.7, No. 2, October 2003.

Flannery-Dailey, F. and Wagner, R., 'Wake Up!: Gnosticism and Buddhism in The Matrix'. Journal of Religion and Film. Vol. 5, No. 2, October 2001.

Gardner, M., 'Introduction to GK Chesterton'. The Man Who Was Thursday. Ignatius, San Francisco, 1999, pp. 9-21.

Pratchett, T. and Gaiman, N., Good Omens. Corgi, London, 1991.

Seaber, L., G.K. Chesterton and George Orwell: A Study in Denied Influence. Lampeter, Edwin Mellen, forthcoming.

Steinhoff, W., George Orwell and the Origins of 1984. University of Michigan Press, Ann Arbor, 1976.

Stucky, M.D., 'He Is the One: The Matrix Trilogy's Postmodern Movie Messiah'. Journal of Religion and Film. Vol. 9, No. 2, October 2005.

Wittung, J. and Bramer, D., 'From Superman to Brahman: The Religious Shift of The Matrix Mythology'. Journal of Religion and Film. Vol. 10, No. 2, October 2006.

Ward, M., Gilbert Keith Chesterton. Rowman and Littlefield, Lanham, 2006.

Luke Seaber teaches at CIEE Italia, Ferrara, Italy, and the University of Pisa. 


\title{
The Evolutionary Villain: Alfred Bester as an Oppressed Victim and a Righteous Villain
}

\author{
Mikko Poutanen
}

\begin{abstract}
This chapter is centred on the character Alfred Bester presented in 'The Psi Corps Trilogy' by J. Gregory Keyes, based on the TV-series Babylon 5 by J.M. Straczynski. The setting is a future world where a considerable telepathic minority is revealed to a non-telepathic majority. Bester is born into a history of conflict for dominance taking place not only between telepaths and non-telepaths, but also between the telepaths themselves. Bester seeks to resolve this stalemate by any means necessary. The setting makes it possible to analyse the very real modern dilemma of one man's freedom fighter being another man's terrorist in a science fiction context. Bester sees his actions as ones of necessity as he seeks out to protect telepaths, and in so doing he holds sympathy as a defender of a minority. When Bester extends his agenda to claim telepaths as 'homo superior', an evolutionary step forward and above non-telepaths, he takes on more definable villainous characteristics. While the perception of 'homo superior' makes drawing parallels to the most readily recognized 'evil' of the 20th century, the National Socialists, effortless, it also conflicts with Bester's claim to oppressed victimhood. Bester sees telepaths simultaneously as superior and yet constantly under attack, making the polarizing rhetoric of the War on Terror also available for a related discussion. Bester, an evolutionary villain, refuses simple or absolute categorizations, and provokes us to question the line between villain and victim. In my analysis Bester gives the villain a face that can be monstrous but also undeniably human at the same time, refusing being dismissed as anomalous, but presenting himself as integrated entity borne out of an evolutionary struggle.
\end{abstract}

Key Words: Telepathy, Bester, evolution, conflict, minorities, evil, villain, victim, Keyes, Übermensch.

$$
* * * * *
$$

\section{Introduction}

The purpose of this chapter is to investigate the treatment of telepathy in science fiction literature and how that connects to villains or villainous acts. The primary materials include J. Gregory Keyes's 'Psi Corps Trilogy' ${ }^{1}$ and the character of Alfred Bester in particular. Due to telepathy's readily recognizable features, an author can utilize it as a method of representation that does not connect directly into the world of the real, but is available for extrapolating meaning and social hierarchy. We are able to recognize telepathy as a concept and, within the 
confines of a book, treat it as if it were real. Wishful thinking at best or parascience at its worst, its persistence in fiction reveals continued fascination in the subject. $^{2}$

Within the books telepathy is mostly used to illustrate how potentially violent the clashes between 'the human' and 'the other' can be. The question then becomes which side, telepathic or non-telepathic, can hold the claim to the word 'normal' and by that extension label the abnormal. As we shall see, in some cases the label is self-inflicted as a perceivably natural extension of victimhood. In addition, telepathy deals with evolution, a scientific fact that can be perceived as monstrous or villainous in a certain context. If evolution is improvement, then a certain degree of advancing the cause of humanity is expected. However, the threat of evolutionary clashes between telepaths and normal humans is a major point to focus the analysis of villainy, as it can derive substance from factual history.

\section{The World of Bester}

Keyes presents the emergence of telepathy and how the dominant societal powers react to it. As telepathy is discovered, the general population reacts violently with paranoid bursts of violence and the first part of the first novel is named 'Holocaust'. ${ }^{3}$ Following the carnage a governmental body is founded to protect citizens from telepaths. Telepaths are given the option of taking the 'sleepers', a drug designed to deaden telepathic capabilities and a part of the personality or to submit to authority. Telepaths essentially either handle their own, or the non-telepaths will do it for them. Not all telepaths are willing to join an organization they see as dubiously authoritarian, ${ }^{4}$ arguing the arrangement only perpetuates the dominant (and oppressive) social order.

Rogue telepaths refusing organizational telepathy are effectively criminals, often equated to terrorists. The segregated areas where telepaths are forced/allowed to live double as compounds and sanctuaries. They also wear clothing that marks them separate from the general populace. Some take pride in their otherness, whereas to others complain they are still singled out. Disillusioned, for many telepaths coexistence appears as a life-long sentence to fear and persecution. The protagonist Bester is presented as highly ambitious and fully loyal to the cause of telepaths. Bester wryly comments that normals tend to prefer that telepaths are kept separate but equal, making a clear reference to segregation of the African American minority in the United States. When his bid for power fails in a civil war of the telepathic community, Bester is considered a monstrous war-criminal.

\section{Othering: Übermensch vs. Untermensch}

In my analysis, telepathy is easily employed to convey 'the other', a concept familiar to us from post-colonial studies and the discourse of power. The construction of the 'Other' is fundamental to the construction of the 'Self' ${ }^{5}$ Ursula LeGuin's analysis of American science fiction points out that the 'other' can 
typically take multiple forms, adapting to what is most pressing at the time. ${ }^{6}$ The conceptual foreignness of the 'other' is often implicitly connected with evil. René Sudre quotes Michel Focault: 'If the influence of mind upon matter does not cease at the surface of the skin, there is no safety left in the world for anyone. ${ }^{7}$

Rather than seen as inhuman, telepathy in science fiction is often seen as 'the super in superman', notes Curtis Smith, ${ }^{8}$ or as an encounter between the 'normalhuman self and the superhuman other'. ${ }^{9}$ But when it comes to actual progress of the human state, the telepath tends to fall short, despite the perception that telepaths would have heightened emphatic abilities as well. In Nietzsche's Thus Spoke Zarathustra ${ }^{10}$ the Übermensch is not necessarily attributed superhuman or extraordinary powers, but instead presented as beyond human, above the pettiest of emotions and desires, yearning to redeem the deplorable human condition. ${ }^{11}$ This, we shall see, is not the case with telepaths. Instead, the telepath could perhaps be called homo superior to signify its more-than-human nature, because perceived supremacy seems integral to a telepathic identity.

If the homo superior can lay claim to evolution as its driving force, it would also legitimise their potential claim to rule over the homo sapiens, or 'normals', as a natural state of affairs. If one accepts the ascension of the other, then it also entails a de facto degeneration of the Self. The sudden emergence of homo superior therefore is a clear threat to normals, a threat which should be annihilated before it can grow. This aspect connects to a very contemporary fear of an attack on the inside by an enemy that is thought to be essentially on the outside, ${ }^{12}$ and the concept of pre-emptive strikes to secure safety, seen e.g. in the war on terror.

However, the victory of the homo superior is not certain, especially if they are in the minority. The homo sapiens can, and will, contest homo superior's claim to supremacy which will inevitably lead to conflict. In his novels Keyes also suggests that telepaths being artificial, products of genetic or technological manipulation, which robs them of their claim to natural ascendancy in an evolutionary struggle, but makes their impetus to try to do to validate their existence no less pressing. This setting provides ample grounds for a telepath victim, but also telepath villain.

\section{Evolutionary Conflict}

Bester's first priority is to consolidate their forces: once unified the telepaths could finally focus on their true adversary, the normals. Bester's villainy is, perhaps unnecessarily, heightened by him doing several deathbed scans in an effort to explore the telepathic inner space at the threshold of death. As a result he ends up seeing himself as an empty shell of a person. ${ }^{13}$ Very shortly thereafter Bester flexes his muscles to interrogate a murderer of telepaths: 'There was not much left of Chandler[...]. Re-education [sic] would be able to do something with him possibly even return him to full sentience, make him a working human being. But however that turned out, he would never again be Thurston Chandler. ${ }^{14}$ Bester 
even laments that as using telepathic powers to overwhelm normals is so easy that he is losing motivation to restrain himself.

The evolutionary narrative seems to have a pessimistic view of human nature. ${ }^{15}$ Telepaths and normals seem to be locked in a never-ending conflict for dominance. If the telepaths saw their future blocked by normals, then normals just as surely saw their future threatened by telepaths. Bester's attitude is telling: 'You normals are obsolete. The future belongs to the telepaths'. ${ }^{16}$ In increasingly sinister undertones he reasons that normals fear them as 'they fear no alien race, because we are them, only better' ${ }^{17}$ Bester's trial is the final chapter of the third novel, set against the background of a world hungry for justice and revenge. Bester comments that his guilt is pre-determined because someone must atone for the blood and assume the blame so the old system can be discredited and the seemingly new one legitimised. He queries if it would make the prosecution feel better if he said his name was Hitler, or Stalin, or Satan.

Bester further argues that the formation of the Corps and the perceived ghetto of Teeptown were acts of oppression, setting the telepaths up for a possible final solution. Telepaths were marked and catalogued 'more certainly and permanently than anyone who ever wore an armband with a star - because that, at least, you could take off'. ${ }^{18}$ Bester's defence hits a potentially sore point in accusing the human race of failing to evolve beyond committing, or repeating, a Holocaust. However, his claim to victimhood is undermined by his villainy: Despite invoking the Holocaust, Bester's methods drew quite close to past fascist examples when it came to authority and indoctrination. The Psi Corps under Bester built re-education camps in the spirit of the Khmer Rouge, and targeted telepaths and their normal accomplices with merciless vigour. 'What you now call the telepath resistance was at the time universally recognizes as an illegal, subversive organization of terrorists', ${ }^{19}$ Bester states, adding that according to the jurisdiction given to him, non-telepaths collaborators were dealt with accordingly. To Bester all means are justified to prevent oppression, even becoming the oppressors themselves. Herein lies the gist of Bester's villainy; it is wrong for telepaths to be oppressed, but it is natural for telepaths to be on top.

\section{Complexity of Evil}

Much like a patriot called a war criminal, Bester does not perceive himself as intrinsically evil while he understands others might be inclined to disagree. It is necessary for Bester to draw on authority and legitimacy that was granted to him freely to protect both the telepaths and the non-telepath populace. Bester can live with his actions by maintaining the illusion that there was no alternative.$^{20}$ Much like in the war on terror, Bester employed methods closer to the 'dark side'. The struggle between good and evil promoted by the Bush administration has similarities with the telepath conflict, presented as a historical battle of ideologies. 
This tends to legitimise so called temporary measures of expanded authoritarian power for the greater good. ${ }^{21}$

While Bester is no Übermensch, Nietzsche's slave and master moralities do seem to fit the normal-telepath -dichotomy; if we see the normals by strength of their majority as the master, then what is harmful to the master, i.e. the ascendancy of telepaths, translates into plain harmful. ${ }^{22}$ Similarly the telepath slave finds itself imprisoned and resents the state of affairs. Conversely if we see the telepath as the stronger party, then the weaker, slaved normals wish to hold them back by labelling them as evil. ${ }^{23}$ The stated other, the enemy, does not have to be active as such but its evil nature manifests simply by existing.

Bester's villainy is supported by his claim to an evolutionary struggle, in which he and his kind have been made the victims. He plays the usual stratagem of being one of the few who can see through the looking glass, or the big picture, take your pick of legitimating euphemism. Bester has not found only mirror labelling between normals and telepaths of deviancy, but also jigsaw-labelling which, according to Morton, enables the more powerful party to claim victimhood. ${ }^{24}$ This seems like a method to shield Bester from his villainy, seeking to supplant the ideology of a natural process, evolution, for fact of being.

In a way Bester is closer to John Keke's analysis of Robespierre, a revolutionary, than a nazi. Bester sees that if he doesn't act, no one else will, and the one-sided suffering of telepaths lays foundation for further atrocities. This is the self-defense instinct of his ideology. ${ }^{25}$ While one could argue that a certain degree of Bester's villainy came from a world of subjugated telepathy, he also relished his personal power, as evidenced by the case of Thruston Chandler. Eagleton notes that perceiving others as potential threats has served humanity well in terms of evolution, ${ }^{26}$ which is only evil from the perspective of the loser. Indeed, it is Bester's final goal than we're left unclear about; we recognize means without understanding the end. Bester never explained how the world with the telepaths on top was supposed to operate, or if he had a practical vision at all. In this evil is supremely pointless, capable of tactics but not strategy.

Bester villainy is not beyond our comprehension because Keyes gives abundant historical context to it. Using the Holocaust would usually trigger sympathies to the telepath side, but Bester erodes that sympathy, taking the discourse away from victimhood and closer to how the surrounding Arab states may view the military prowess of modern Israel. His claim on evolution is further weakened by the possibility that telepaths are not at all products of evolution but artificial creations of gene manipulation.

As such Bester's claim that his guilt has been pre-determined is true; the historical narrative demands a villain so the books can be closed on evil, at least for the time being. The trial itself seeks to end a seemingly infinite human capacity for evil by giving it a finite boundary by trialling Bester. It is also necessary for reconciliation; as long as othering is rampant, perceived transgressions become 
proof-positive of the equation that the other is evil. ${ }^{27}$ Bester's villainy also allows us to sidestep the responsibility of his peers who joined this ideology of evolutionary conflict. Bester has to be held accountable and the fact that he is a telepath serves well in demonising him; evil has to be readily recognized and is expected to be exceptional, not commonplace, i.e. not us. ${ }^{28}$

\section{Conclusion}

The telepathic villain seems to invoke potential for a plethora of themes to be explored, including putting villainy itself in question. In essence, the novels are not about $p s i$ as much as it about human and natural community. ${ }^{29}$ It is even mused, out loud, if telepaths might suffer the usual history of minority groups. ${ }^{30}$ While othering excludes and marginalizes, and ultimately dehumanises, it is never a oneway interaction. Those 'othered' quickly develop their own classification for those that would oppress them, legitimising their struggle for freedom. The same choice of freedom - control -dichotomy is presented in other works of American science fiction, such as in the movie X-Men: The Last Stand (2006). ${ }^{31}$ An authority to impose control is necessarily seen as a repressive entity in American, highly individualistic science fiction. This view has, however, somewhat changed in political discourse after $9 / 11$ and ushered in a more pronounced approach to evil.

Bester is no Übermensch but perhaps a peculiar Untermensch with considerable power, very much susceptible to human failings. In essence Bester's vision of an evolutionary clash would consign a large number of people as obsolete, which is not possible without villainous actions. To have power in a society entails the power of defining normality, and to non-telepaths telepathy is something that threatens their uniqueness. Bester argues that this is a natural process, and that normals are staving off the inevitable. The Darwinist becomes a villain when the perceived natural order has to be expedited; the telepaths cannot afford to wait for evolution to grant them supremacy since by sheer numbers the normals refuse to cede it. 'If you were in my shoes', Bester seems to suggest, we would act like he did. He didn't seek to become a villain, but by establishing his Self in a context of societal conflict, all power seems to corrupt. Certainly using telepaths as a literary method does not mean, at least in Bester's case, that they would usher in a new era of peace, unity and understanding. John Christopher's The New Wine features a human race suddenly made fully proficient in telepathy, but a hundred years later life is almost over, 'for when people can see and know each other as they really are, they prefer to die'. ${ }^{32}$

\section{Notes}

${ }^{1}$ The Psi Corps Trilogy is a term used by several sources, classifying the three books under a single heading. It includes the following three books in chronological order: (I) J.G. Keyes, Dark Genesis: Birth of the Psi Corps, 
Ballantine, New York, 1998; (II) J.G. Keyes, Deadly Relations: Bester Ascendant, Ballantine, New York, 1999; (III) J.G. Keyes, Final Reckoning: The Fate Of Bester, Ballantine. New York, 1999; The books are set in the world of J.M. Straczynski's Babylon 5 http://www.imdb.com/title/tt0105946/.

${ }^{2}$ It's worth noting that many of these experiments are still being conducted, and some even claim positive results. R. Luckhurst, The Invention of Telepathy: 18701901. Oxford University Press, Oxford, 2000, p. 277.

${ }^{3}$ Keyes I, p. 17.

${ }^{4}$ Relating to hierarchy and power-structures, U. LeGuin connects the tendency of science fiction to establish authoritarianism. LeGuin, "American SF and The Other', p. 89. The mass-controlling hierarchy dichotomy is also a very Nietzschean interpretation. Ansell-Pearson, op. cit., pp. 4 \& 6 .

${ }^{5}$ B. Ashcroft, G. Griffiths and H. Tiffin, Key Concepts in Post-Colonial Studies. Routledge, London, New York, 1998/1999, p. 172.

${ }^{6}$ U. LeGuin, 'American SF and The Other', The Language Of The Night - Essays of Fantasy and Science Fiction, Berkley Books, New York 1982. p. 87.

7 R. Sudre, Treatise on Parapsychology, C.E. Green (trans), George Allen \& Unwin Ltd., London, 1960. pp. 32-33.

${ }^{8}$ C.C. Smith. 'Olaf Stapledon's Dispassionate Objectivity', Voice For the Future: Essays on Major Science Fiction Writers. Vol. 1, D. Thomas (ed), Bowling Green University Popular Press, Bowling Green, 1976, pp. 46-47 \& 54.

${ }^{9}$ C.D. Malmgren,. 'Against Genre/Theory: The State of Science Fiction Criticism', Poetics Today, Vol. 12, No. 1, Spring 1991, p. 128.

10 F. Nietzsche, Thus Spoke Zarathustra, R.J. Hollingdale (trans), Penguin, Harmondsworth, 1961.

${ }_{11}$ K. Ansell-Pearson, An Introduction to Nietzsche as a Political Thinker, Cambridge University Press, Cambridge, 1994, pp. 7 \& 120. A curious link here to the title of Theodore Sturgeon's More Than Human can be made.

${ }^{12}$ B.W Aldiss, Trillion Year Spree, Victor Gollancz, London, 1986, p. 255. See also J. Hienger, 'The Uncanny and Science Fiction', Science Fiction Studies, Vol. 6, July 1979. DePauw University. Accessed at: http://www.depauw.edu/sfs/back issues/18/hienger18art.htm.

${ }^{13}$ Keyes II, op. cit., p. 189.

${ }^{14}$ Ibid., p. 161.

${ }^{15}$ Smith, op. cit., p. 47.

16 'Ship of Tears', Babylon 5.

${ }^{17}$ Keyes III, p. 38.

${ }^{18}$ Ibid., p. 244.

${ }^{19}$ Ibid., p. 242.

${ }^{20}$ M.J. Straczynski, 'The Profession of Science Fiction: Approaching Babylon', Foundation: The Review of Science Fiction, Vol. 64, Summer 1995, p. 15. 
${ }^{21}$ T. Eagletonm On Evil, Yale University Press, New Haven and London. 2010, p. 157.

${ }^{22}$ F. Nietzsche. Beyond Good and Evil, Oxford University Press, Oxford. 1998, p. 154.

${ }^{23}$ J. Kekes, The Roots of Evil, Cornell University Press, Ithaca / London. 2007. pp. 129-130.

24 A. Morton, On Evil, Routledge, Taylor \& Francis Group, New York and London, 2005, p. 101.

${ }^{25}$ Kekes, op .cit., p. 16.

${ }^{26}$ Eagleton, op. cit., p. 39.

${ }^{27}$ Kekes, op. cit., p. 96.

${ }^{28}$ Ibid,. p. 13 and Morton, op .cit., p. 31.

29 P.M. Lowentrout, 'PsiFi: The Domestication of $P s i$ in Science Fiction', Extrapolation, Vol. 30, No. 4., Kent University Press, 1989, p. 395.

${ }^{30}$ A. Bester, The Demolished Man, Millennium, London, 1999. p. 207.

${ }^{31}$ In the third instalment of the comic-based superhero movie, the mutants with peculiar talents (including telepathy) are given the option of taking an injection that would act as an inhibitor to their talents if not submit. Some prefer to return to a predominantly normal society while others see it as an attack against what and who they are.

32 R. Williams. 'Science Fiction', Science Fiction Studies, Vol. 15, Part 3 November 1988. DePauw University. Accessed at http://www.depauw.edu/sfs/ documents/williams.htm.

\section{Bibliography}

Aldiss, B.W., Trillion Year Spree. Victor Gollancz, London, 1986.

Ansell-Pearson, K., An Introduction to Nietzsche as a Political Thinker. Cambridge University Press, Cambridge, 1994.

Babylon 5, Television Series, 1994-1998, created by J. M. Straczynski, Acquired 17.2.2006. http://www.imdb.com/title/tt0105946/,

Bester, A., The Demolished Man. Millennium, London 1999.

Bill, A. et. Al., Key Concepts in Post-Colonial Studies. Routledge, London, New York, 1998/1999.

Eagleton, T., On Evil. Yale University Press, New Haven and London, 2010. 
Hienger, J., 'The Uncanny and Science Fiction', Science Fiction Studies. Vol. 6, Part 2, July 1979, DePauw University, Acquired 20.04.2007 at: <http://www. depauw.edu/sfs/backissues/18/hienger18art.htm.

Kekes, J., The Roots of Evil. Cornell University Press, Ithaca and London. 2007.

Keyes, G.J., Dark Genesis: Birth of the Psi Corps. Ballantine Publishing, Del Rey, 1998.

—, Deadly Relations: Bester Ascendant. Ballantine Publishing, Del Rey, 1999.

—, Final Reckoning: The Fate Of Bester. Ballantine Publishing, Del Rey, 1999.

—, Internet Speculative Fiction DataBase. http://www.isfdb.org/cgi-bin/ea.cgi? J.\%20Gregory\%20Keyes, Acquired 08.03.2007.

LeGuin, U., 'American SF and The Other'. The Language Of The Night-Essays of Fantasy and Science Fiction. Berkley Books, New York, 1982, pp. 87-90.

Lowentrout, P.M., 'PsiFi: The Domestication of $P s i$ in Science Fiction'. Extrapolation. Vol. 30, No. 4., Kent University Press, 1989, pp. 388-400.

Luckhurst, R., The Invention of Telepathy: 1870-1901. Oxford University Press, Oxford, 2002.

Malmgren, C.D., 'Against Genre/Theory: The State of Science Fiction Criticism'. Poetics Today. Vol. 12, No. 1, Spring 1991, pp. 125-144.

Mendelshon, F., 'Introduction: Reading Science Fiction'. The Cambridge Companion to Science Fiction. Cambridge University Press, Cambridge, 2003.

Morton, A., On Evil. Routledge, Taylor \& Francis Group, New York and London. 2005.

Nietzsche, F., Thus Spoke Zarathustra. Penguin, Harmondsworth, 1961.

Smith, C.C., 'Olf Stapledon's Dispassionate Objectivity'. Voice For the Future: Essays on Major Science Fiction Writers. Vol. 1, Bowling Green University Popular Press, Bowling Green, 1976. 
Straczynski, M.J., 'The Profession of Science Fiction, 48: Approaching Babylon'. Foundation: The Review of Science Fiction. Vol. 64, Summer 1995, pp. 5-19.

Sudre, R., Treatise on Parapsychology. George Allen \& Unwin Ltd., London, 1960.

Williams, R., 'Science Fiction'. Science Fiction Studies. Vol. 15, Part 3, November 1988. DePauw University. Accessed at http://www.depauw.edu/sfs/documents/ williams.htm, Acquired 21.04.2007.

Mikko Poutanen is a drone working for a corporate hive. In his spare time he longs to improve his mental faculties by keeping touch to the world of academia at every possible turn. He is an alumni of Tampere University, and writes both fiction and academic material. 


\title{
The Cyborg Villain: Mechanical Hybridity and Existential Fear
}

\author{
Jori De Coster
}

\begin{abstract}
'This technology will blow your mind': a mobile life support system that protects the burned body, bionic armour, infrared eyes that take snapshots, a cybernetic exoskeleton, a mechanical arm that feels, prosthetic legs constructed to run as fast as a cheetah, implants to hear again or communicate by moving a cursor on a computer screen with your eye movements...It is difficult to tell whether the above are just cyborg requisites from Star Wars or Blade Runner or actually scientific reality anno 2010. The post-human as Manfred Clynes or modern filmmakers imagined it is not just Sci-Fi anymore: slowly but surely all kinds of technologies are penetrating our lives and the discussion on when precisely we started to become some kind of cyborg and how far this 'evolution' will lead us is ongoing at the speed of light and mesmerizing. Human hybridity (a mixed composition of the human state of being with the spiritual, animal, technological...) has always been a cause for unease. Humans who stand at the border by incorporating technology question their but also our humanity. In this chapter we state that cyborg villains (such as Darth Vader, the Borg, Cylons and many others) just like any other form of human hybridity embody anxiety and are pure existential fear about the loss of humanity given shape. Through analyses of different cyborg villains as represented in mainstream cinema we state that this new form of human hybridity is constantly negotiated in public space in terms of e.g. religion, morality, emotions, gender and tells us something about how we think about humanity and especially what it means to be human in western (post)modern society.
\end{abstract}

Key Words: Boundary-crossing, cyborg, dichotomy, existential fear, humanity, hybridity, technology.

$* * * * *$

\section{1. 'You will be assimilated. Resistance is futile'1}

On January 3, 1983, one day after I was born, Time magazine presented its annually elected 'Man of the Year'. Only, this year the distinction was given to the computer who according to Time was (fifty years after its creation) 'moving in'. Nowadays a (Western) world and body's realm without technological invasion and dependence seems unthinkable. The post-human as Manfred Clynes or modern filmmakers imagined it is not just Sci-Fi anymore: as we speak counsels on the level of companies but also nations and higher institutions (e.g. European Union) are forced to take decisions about the makings of our 'cyborg future'. Reports of implants, clones, cybernetic exoskeletons, avatars, nanotechnology, professors who upgrade themselves through device implementation, and A-life are daily news and 
the discussion on precisely when we started to become some kind of cyborg and how far this 'evolution' will lead us is ongoing at the speed of light and mesmerizing.

Human hybridity (a mixture of the human state of being with the spiritual, animal and/or technological) is all about breaching boundaries. Hybridity exists in all times and places and has always been a cause for unease. ${ }^{2}$ It is especially modern Western ${ }^{3}$ society that displays a lot of 'cyborg' hybridity both in real life and fiction. Thus, cyborg villains tend to be the modern (Western) hybrid monsters, representing contemporary fears and conflicts, and replacing previous mythological evil creatures that were often killed by heroes with new forms of distress and catharsis.

The word cyborg was coined in 1960 by the neurologist Dr. Clynes and his colleague Nathan Kline who suggested the possibility of space travel by altering the human body through drugs (and thus turning the body into a cyborg). Soon the term started to lead a life of its own in science. ${ }^{4}$ When popular culture recuperated the term Clynes expressed his discontent with the way the concept cyborg was completely dehumanized, 'with Schwarzenegger playing this thing, (...) a travesty of the real scientific concept (...). A monsterification of something that is a human enlargement of function'. These 'travesties' or manipulations of the cyborg in media (literature, movies, games, comics, art), however, offer us impressions of cyborgian culture and an understanding of our/selves.

Visual representations of cyborgs are... not only utopian or dystopian prophecies, but rather reflections of a contemporary state of being. The image of the cyborg body functions as a site of condensation and displacement. It contains on its surface and in its fundamental structure the multiple fears and desires of a culture in the process of transform-ation. ${ }^{5}$

Here we start by saying that human hybrids who stand at the border by incorporating technology raise contemporary questions on their but also our humanity. The many aspects of technology's relation with the human body and consequently the self are constantly negotiated in (popular) culture's public space in terms of e.g. religion, morality, emotions, free will, etc. Thus, cyborg villains epitomize boundaries of humanness and reflect a specific existential fear that relates to the apocalyptic and dehumanizing aspects of technology. However, feminist writers such as Donna Haraway state that our cyborg ontology is already fact and should not be feared but celebrated. Adding a political meaning to the cyborg, she arguments for 'pleasure in the confusion of boundaries and for responsibility in their construction'. ${ }^{6}$ According to Haraway the cyborg contests typical western dichotomies and must be seen as an opportunity to free ourselves from oppressive binary structures to create a post-gender utopia. 
Through narrative analysis of different movies this chapter puts a number of mainstream cyborg villains under the looking glass and reveals multiple reflections on our Western contemporary state of being.

\section{2. 'He is more machine now than man; twisted and evil'}

Being a hybrid, ambiguity seems to be a first natural characteristic of the cyborg. As Donna Haraway puts it in her Cyborg Manifesto 'a cyborg is a cybernetic organism, a hybrid of machine and organism', but also 'a creature of social reality as well as a creature of fiction'. The cyborg villain's ambiguity consists of the fact that he is not always just 'evil' but also possesses 'good' qualities.

The very ambiguity with which many of the cyborg heroes and villains are portrayed, good guys become bad guys and vice versa, is indicative of our unease with these creations. ${ }^{9}$

Villains and heroes often embody both positive and negative possibilities of the organism-machine blend. ${ }^{10}$ The post-human, ${ }^{11}$ which is the fully technologized successor species to organic homo sapiens, displays technology as liberation from nature, disease, death. ${ }^{12}$ Technology is not just something evil; it saves and lengthens our lives, it makes us communicate, remember, relax, it contracts time and space, it fulfils our wildest dreams. In short, it turns us into super/humans.

We attribute 'evilness' to technology when we tend to loose control over it ${ }^{13}$ or when technology starts to control us and/or when it erodes our humanity. The Terminator for instance is ranked number 22 on The American Film Institutes' list of villains but in Terminator II the Schwarzenegger cyborg is not programmed to destroy Sara Conner (and thus humanity) anymore, but to save John Connor (and thus humanity). As a cyborg villain Darth Vader stands in between man and machine, between hero and villain and between the good side and the dark side of the Force. George Lucas portrayed Darth Vader as the child Anakin Skywalker in episode I of Star Wars and as a good father just before he died (some would say after his redemption) in episode VI. It is Darth Vader who as a Christlike-figure fulfils the prophecy of restoring the balance between good and evil in the Force. In Blade Runner the concept of goodness/morality is ascribed to the replica Roy Batty as he saves the protagonist's life. ${ }^{14}$ Even the Cylon copy Six from Battlestar Galactica sacrifices her own life to save her human lover Baltar. However, the Borg Queen in Star Trek First Contact is an example of a cyborg villain that shows no goodness, only sexuality which in this context is not considered to be a good thing.

Frequently the viewer also finds himself sympathizing with the cyborg villain, e.g. in his search to destroy its own creator to whom 'evilness' can be ascribed as much so. We certainly feel relief when Roy Batty has a lethal meeting with his 
maker Eldon Tyrell. Darth Vader kills his tyrannical boss and creator Palpatine and the Terminator destroys Miles Bennett Dyson, a programmer for Cyberdyne. We tend to forget that the real Frankenstein is not the creature but the creator and that playing God $^{15}$ and thus playing with humanity always invokes punishment.

Risking the end of human existence can be understood in two ways. First, movies staging cyborg antagonists tend to give warnings about possible apocalyptic futures as they are mostly set in futuristic human depriving environments or directly deal with the ultimate downfall of humanity. The Terminator is partially set in 2029 when man and machine are fighting in a postnuclear wasteland for their survival. When the supercomputer Skynet sends the Terminator back in time to destroy Sara Connor this is to prevent the birth of future rebel leader John Conner who is the only one capable of saving humanity. Blade Runner is set in the same 'film noir' kind of dystopian Los Angeles of 2019 where there is a confusing difference between humans and the replicants whose removal is arranged. Darth Vader's Death Star is constructed to enforce complete domination through its ability to destroy other planets. In Battlestar Galactica the Cylons hunt down what seems to be the last surviving human colony through deep space. In Star Trek First Contact the Enterprise succeeds in abolishing the Borg Cube's total assimilation of planet earth. The Borg is a networking collective of drones who assimilate other species in their search for perfection. Assimilation means becoming a zombie-like functional part of the system through injection of nanoprobes. As all communication is shared, they function as a single consciousness or 'hive mind' that is regulated by a central control system, namely the Borg Queen. Here, the end of human existence stands for the end of individuality.

Second, cyborg villains portray various possible dehumanizing aspects of technology. Cyborg villains show signs of dehumanization first of all through a decrease of the biophysical body and consequently the 'self' or the 'soul'. Moreover, the body-spirit duality is often connected to morality and religion. In Star Wars Darth Vader's path to the dark side and back goes together with technological transformations in which he loses his humanness, his soul, and becomes a machine. The loss of his soul and rebirth as a machine happens gradually and coincides with the loss of several body parts. In some of the central scenes Skywalker (both father and son) cut off a hand or lose one themselves and get prosthetic replacements. After losing half his body in lava flow the mechanical exoskeleton $^{17}$ in Star Wars III represents Anakin's final transformation and incorporation to the Dark Side. However, Darth Vader has not become completely inhuman as we can see in episode VI when he saves his son (or is it the son's love that saves the father) by destroying the creator of his mechanical body. After this act Luke Skywalker takes of the helmet of his father and we hear Anakin's last breath, now without the mechanical sound of the breathing mask. Darth Vader's 
(Dark) last appearance is nothing else than the full-bodied ghost or soul of Anakin Skywalker as a Jedi (Light), released of all its mechanical body parts and evilness.

Although Schwarzenegger was not the first choice for the Terminator, the bodybuilder fits the body of a futuristic machine meant for killing well. His capacities to destroy everything on its way to complete its mission and to survive all counterattacks however seem to be supernatural, even for a body that muscular. Throughout the action the cyborg, a robot disguised with human tissue to infiltrate, gradually loses all his living tissue, including his eyes and skin, which reveals him as a metal endoskeleton, the T-800, with mechanical red led-eyes. He really is nothing more than a machine, showing no mercy and no emotions. When he is finally crushed under a press by Sara the only thing that remains is his 'prosthetic' arm and CPU.

Starting as a real femme fatale the Borg Queen is gradually revealed as just a human head on a mechanical body, but even later when her face and upper torso are dissolved too she turns out to be a complete machine.

Whereas in Terminator I the human eye is removed to reveal the machine's evil true being, the eye as a mirror of the soul is used in Blade Runner as the ultimate tool in the Voight-Kampff test on empathy to differ between humans and replica's. The movie's protagonist Deckard however is unable to make the difference as replicas too have evolved emotions (fear for mortality, love, anger, compassion...) and even the viewer gets confused when Deckard himself resembles a replica. If being human means having a soul what to think of the dove that symbolizes Roy Batty's spirit going to heaven after he dies. Thus, shifts in morality usually interact with switching borders between man and machine and our greatest fear is when the machine part overcomes the human or questions boundaries of our/self. ${ }^{18}$

The cyborg also questions humanity and its possible dehumanization through biophysical aspects such as production and reproduction and consequently mortality. Machines are not physically born, but mechanically made. They are without memory (and thus history) ${ }^{19}$ and for eternity. It was Skynet who created the Terminator. ${ }^{20}$ Paradoxically, Skynet itself was developed out of the recovered CPU of the Terminator I. As a very powerful, muscular male with black leather outfit the Terminator is also analysed with reference to gay culture. ${ }^{21}$ His only mission is to disrupt a natural cycle of reproduction and birth by chasing Reese and Sara, the parents of John Connor, the saviour of humanity. For the Terminator dying is a difficult thing to do; the hand that is finally left 'lifeless' in Terminator I will make for a complete 'I will be back' reoccurrence in the sequel.

Anakin has two unnatural births; first he is born without a father out of Midichlorians, being the smallest life creating parts of the Force. His second birth as the machine Darth Vader is paralleled with the 'real' birth of his twin children. His love for his child will make him human again and makes him die.

The Borg originated as something humanlike but upgraded themselves and could stay like this for infinity. Often reminding of a hive queen the Borg Queen's 
sexuality is not used for real reproduction as new drones are 'born' through assimilation of implants. Moreover, her sexuality is part of her characterization as a villain that especially threatens the relation between Picard and Data. As proof of their friendship both men realise her death together.

Both Replicas and Cylons are made by big corporations. The fact that they are made also means they lack personal (and genetic) history. Cylons and replicas only have fake-programmed memories. The human-like replica's in Blade Runner however feel love and strive for immortality. They fight against the dying of the light, as they only have four years of existence. The fact that they fear their mortality however is part of the confusing difference between humans and replicas in Blade Runner. When they turn to their maker with an immortality wish they are punished for this by execution called 'retirement'. Roy finds a piece of immortality by saving Deckard's life and thus living further in his memories after death.

\section{Conclusion}

Each epoch shows hybrid monsters that reflect contemporary fears and conflicts. As technology invades our lives the idea of becoming post-humans seems realistic and needs to be dealt with on an imaginary level. The shifting nature of the cyborg villain relates to the dehumanizing aspects of technology but also questions humanness. How much technology is needed to erase the human being and what is a human being? Is it empathy, love or some other emotion? Is it our biophysical condition or mortality that makes us who we are? Are we the only beings that make history through memory? Is it the existence of a soul or a religious belief in God? What separates us from everything else?

Moreover, the cyborg villain especially reflects the state of the homo sapiens and humanity today, in a (post)modern world context. Leaky boundaries, e.g. between humans and Replicas or Cylons, allow confusing reflections on the essence of humanity but why does boundary-crossing needs penalty? Both the human creator and his creation seem to be punished because they question God. The creator plays God and the creation is an ungodly creature. Both threaten human existence (through apocalyptic futures or dehumanization) but most importantly, being boundary creatures, they disturb order.

As an in-between figure the villain reflects contemporary transgressions of western culture's dichotomies and thus undermines order. Therefore the cyborg villain must be destroyed or fit the dichotomy. Although he tends to have human qualities Roy Batty must die, but Deckard who lacks 'human' empathy will live. Darth Vader's death is related to order restoration, after which he transcends with a full human body to Jedi 'heaven'. The Borg Queen, one of the few female cyborg villains, threatens individualism and damages male relations with her sexuality so she must be completely dissolved. The gay-leather wearing Terminator who threatens the natural father-son relation through destruction of the mother figure Sara, must be terminated himself or be reprogrammed to help humanity. The 
dichotomies that are threatened here through the cyborg's hybrid character are typical for (white) male heterosexual patriarchal (Judeo-Christian) tradition. Further, 'representation practices serve not only to portray and report, but to legitimize, to reproduce and to normalize, or to subvert, to contradict and destabilize'. ${ }^{22}$ Thus the cyborg villain embodies a 'border war ${ }^{23}$ both in text and context. However, instead of fear of border-crossings postmodern culture uses the cyborg hybridity as a way to dispose repressing boundaries (e.g. Donna Haraway's argument on male/female, culture/nature dichotomies) for what they are and suggest liberating alternatives. And so the ambiguous cyborg villain embodies possibilities of another perhaps better world.

\section{Notes}

${ }^{1}$ Quote from the Borg Queen in Star Trek First Contact.

2 As a matter of fact mythology is filled with 'boundary' figures such as the Minotaur, Pan, Horus, Ganesha, chimera, the Sphinx or the mermaid. The latter can for instance be found in Brazilian and Western-African culture where she is a goddess called respectively Yemanja and Mami Wata. In Africa the lack of pigment still links a 'ghostlike' person with albinism to the spiritual world. Comparatively angels are supernatural humanlike messengers that can be traced back to different religions. The typical Western hybrid is a cyborg which takes us back to movies such as Fritz Lang's Metropolis (1926), literature such as Marry Shelly's gothic novel Frankenstein (1818) or the cyberpunk genre represented by William Ginson's Neuromancer (1984), but also art e.g. the performances of Stelarc. Western movies indulge in all kinds of hybrid representations; Splice (2010), X-Men Origins: Wolverine (2009), The Fly (1986), Dawn of the Dead (1978), Rabid (1977), Nosferatu (1922) and many more.

${ }^{3}$ Another term would be developed countries' cinema as Asian countries such as Japan and China e.g. display cyborgs (e.g. Tetsuo, Akira) too. This analysis does not include Asian cinema however.

${ }^{4}$ In science the cyborg idea developed especially in medicine but also the military context.

5 J. Gonzalez, 'Envisioning Cyborg Bodies: Notes from Current Research', The Cyborg Handbook, Routledge, London, 2001, p. 267.

6 D. Haraway, Simians, Cyborgs, and Women: The Reinvention of Nature, Free Association Books, London, 1999, p. 150.

${ }^{7}$ Quote from Obi-Wan in Star Wars episode VI: Return of the Jedi.

${ }^{8}$ Ibid., p. 149.

${ }^{9}$ M. Oehlert, 'From Captain America to Wolverine: Cyborgs in Comic Books, Alternative Images of Cybernetic Heroes and Villains', The Cyborg Handbook, Routledge, London, 2001, p. 226. 
10 Comics often use hybridity to explain both their heroes' and villains' superpowers (cfr. Iron Man, Wolverine, Cyber, Doctor Doom). The horror genre manipulates hybridity to frighten their audiences with monstrous figures and action movies often portray villains and heroes who thanks to technology are able to respectively almost destroy or save the world ones again (cfr. Robocop, Crank). Thus, cyborgs can be both heroes and villains, but they always carry some kind of reflection on human hybridity, in this case the relation between humans and technology.

11 The cyborg is closely related to the post-human (post/human, post-human) narrative which is presented by authors such as Francis Fukuyama, Ray Kurtzweil, Max More and Hans Moravec.

${ }^{12}$ Cooper in Graham, 2002, p. 9.

${ }^{13}$ Hence the many 'computer' or 'computer program' villains going wild e.g. Skynet in Terminator, Mr. Smith in The Matrix, the Master Control Program in Tron etc.

${ }^{14}$ Another reason why Roy saves Deckard's life is to become immortal as one of Deckard's memories.

${ }^{15}$ E.g. the Tyrell Company that creates the replicas is directly associated with God when at the beginning of the movie a human/replicant eye fades away and shows the triangular 'all seeing eye' of god or the company.

${ }^{16}$ This mechanical body-spirit dualism can also be found in Asian movies e.g. Ghost in the Shell.

${ }^{17}$ This exoskeleton functions as a life support system that keeps DarthVader alive.

${ }^{18}$ This is related to as the 'ghost in the machine'. The Ghost in the Machine was a book written by A. Koestler in 1967. The title refers to the philosopher Gilbert Ryle who mocks Descartes' mind-body dualism. Koestler discusses the idea that primitive brain structures can sometimes overpower logical functions which creates acts of hate and will lead to the final self destruction of humanity. This philosophy can be found in e.g. the manga Ghost in the Shell in which 'the ghost' stands for the one thing that makes people still retain their humanity, no matter how much technology they incorporated.

${ }^{19}$ This missing of history can hence be associated with missing 'the Garden of Eden', cfr. Haraway in Simians, Cyborgs, and Women. The Reinvention of Nature.

${ }^{20}$ The construction of the cyborgs is explicitly show in Terminator II.

${ }^{21}$ Cfr. Authors writing from Queer or Gender Theory such as D. Greven, 'Cyborg Masochism, Homo-Fascism: Rereading Terminator 2', and J. Goldberg in 'Recalling Totalities: The Mirrored Stages of Arnold Schwarzenegger'.

${ }^{22}$ E.L. Graham, Representations of the Post/Human: Monsters, Aliens and Others in Popular Culture, Manchester University Press, Manchester, 2002. p. 26.

${ }^{24}$ Word taken from Haraway, 1999. 


\section{Bibliography}

Goldberg, J., 'Recalling Totalities: The Mirrored Stages of Arnold Schwarzenegger'. The Cyborg Handbook. Renegade, Barcelona, 2001.

Gonzalez, J., 'Envisioning Cyborg Bodies: Notes from Current Research'. The Cyborg Handbook. Routledge, London, 2001.

Graham, E.L., Representations of the Post/Human: Monsters, Aliens and Others in Popular Culture. Manchester University Press, Manchester, 2002.

Gray, G.C., Cyborg Citizen: Politics in the Posthuman Age. Routledge, New YorkLondon, 2001.

-, 'An Interview with Manfred Clynes', in The Cyborg Handbook. Routledge, London, 2001, pp. 43-53.

Haraway, D., Simians, Cyborgs, and Women: The Reinvention of Nature. Free Association Books, London, 1991.

Hayles, N.K.,'The Life Cycle of Cyborgs: Writing the Posthuman'. The Cyborg Handbook. Routledge, London, 1995.

Oehlert, M., 'From Captain America to Wolverine: Cyborgs in Comic Books, Alternative Images of Cybernetic Heroes and Villains'. The Cyborg Handbook. Routledge, London, 2001.

Shilling, C., The Body in Culture, Technology \& Society. SAGE Publications Ltd., London, 2005.

\section{Filmography}

Blade Runner (1982). directed by Ridley Scott.

Battlestar Galactica: The Plan (2009). directed by Edward James Olmos.

Star Trek First Contact (1996). directed by Jonathan Frakes.

Star Wars Episode I: The Phantom Menace (1999). directed by George Lucas.

Star Wars Episode II: Attack of the Clones (2002). directed by George Lucas. 
Star Wars Episode III: Revenge of the Sith (2005). directed by George Lucas.

Star Wars Episode IV: A New Hope (1977). directed by George Lucas.

Star Wars Episode V: The Empire Strikes Back (1980). directed by George Lucas.

Star Wars Episode VI: The Return of the Jedi (1983). directed by George Lucas.

The Terminator (1984). directed by James Cameron.

Terminator II: Judgement Day (1991). directed by James Cameron.

Jori De Coster completed a Master degree in Literature and in Social and Cultural Anthropology at the Katholieke Universiteit Leuven, Belgium. She worked as a researcher in applied anthropology for VZW Expeditions and was a staff member at the Anthropological Summerschool in Malta. Jori is currently working as an assistant in Anthropology at the faculty of Social Sciences at the Katholieke Universiteit Leuven. Her research focuses on visual anthropology and anthropology of the body in relation to technology and borderlands. 
PART VIII

\section{Villainous States}





\title{
Sexual Villainy in the Holocaust
}

\author{
Beverley Chalmers
}

\begin{abstract}
A particularly venomous aspect of Nazi ideology directed against the Jew focused on the sexual proclivities of 'licentious' Jews and, in contrast, the 'pure' virginal qualities of Aryan women. Biologically, Jews were depicted as polluting and infecting pure 'Aryan' women through forced sexual contact as well as being morally corrupt through their promiscuity. 'Aryans', however, as the superior 'Master Race' were depicted as heroic, pure, self-sacrificing and upholding simple lifestyles, and above all, fellowship. In reality, however, the villains in the Holocaust, particularly with regard to sexual behaviour, were German rather than Jewish. Significant acts of sexual brutality were perpetrated by Germans against men and women, heterosexuals as well as homosexuals, Jews and non-Jews, including humiliating nudity, physical and sexual abuse, cruelty, torture and rape. Such sexually directed villainy was perpetrated out of fear, hatred, power, or even for pleasure. This chapter will explore the ideological image of the sexual villain and the real villain in the Holocaust era.
\end{abstract}

Key Words: Holocaust, Nazis, Germans, ideology, sexuality. sexual brutality, Jews, non-Jews.

$* * * * *$

\section{The Ideological Image of the Sexual Villain}

Hitler had popularised the conceptualisation of the licentious Jew in the 1920s with his writing:

The black-haired Jewish youth lies in wait for hours on end, satanically glaring at and spying on the unsuspicious girl whom he plans to seduce, adulterating her blood and removing her from the bosom of her own people. ${ }^{1}$

This image was further propagated by novels such as Artur Dinter's popular novel (1919) depicting a Jew with numerous non-Jewish lovers - Die Sünde wider das Blut, ${ }^{2}$ and in films including $J u d S \ddot{u} \beta,{ }^{3}$ which depicted Jews as financial manipulators and rapists and Der Ewige Jude that portrayed Jews as vile, dirty and verminous. Der Sturmer, a virulently anti-semitic, and widely distributed newspaper further popularized these images. 


\section{The Real Sexual Villain}

The Holocaust is known for its physical and psychological cruelty towards Jews. While images of emaciation and mass murder are commonly acknowledged, sexual perversions of the Nazis are less well known. These acts of cruelty occurred in towns and villages, ghettos, prisons and concentration camps. Their targets included men, women and children and groups such as homosexuals. While Nazi ideology depicted the Jews as licentious and sexually abusive, it was in fact Nazis that were the perpetrators of the most heinous acts of sexual depravity.

\section{Jews}

The Nuremberg laws rapidly removed Jews from most active segments of German life, eventually separating them into ghettos. Sometime during 1941 the 'Final Solution' was implemented. Jews were sent to labour or concentration camps to be worked to death, or to extermination camps where they were murdered on arrival. In camps men and women were systematically dehumanised through actions designed to remove any remaining vestiges of humanity. These included removing their names, clothes, possessions, bodily hair, husbands or wives, children and other family members, means of cleanliness, and privacy for living, washing, or fulfilling basic bodily functions. Women's internal organs were searched for hidden valuables. They were repeatedly forced to strip naked and were subjected to 'selections' for gassing, based on their level of debility or, in some instances, the whims of SS guards. Sexual activity in the camps was reduced to a minimum by separating men and women. Sexual exchange became possible for some who were able to barter their bodies for a slice of bread, or a lifesaving pair of shoes. On the positive side, however, because of the severe Nazi restrictions against sexual contact with Jews for fear of contamination of the German race (Rassenschande), many if not most Jewish women were spared from rape or from forced prostitution.

\section{Aryans}

Despite the image of the German as heroic, pure, self-sacrificing and upholding simple lifestyles, and above all, fellowship, promoted by the powerful and effective Nazi propaganda ministry, Germans during the Nazi era were sexually prolific. While their regime decried 'degenerate' sexuality it also promoted 'healthy sexuality' and many chose to indulge in this with enthusiasm. Reports indicate that fewer than five percent of German girls were virgins at marriage. ${ }^{4}$

In addition, prostitution became an integrated part of the Nazi endeavour particularly during the war years. 'Pure' German women, like Jews, were exempt from forced prostitution, although they were exhorted and encouraged to voluntarily have intercourse with 'pure' Aryans to bear progeny for the Reich. All other categories of women - usually prisoners - could be enticed, or forced, to become prostitutes. Prostitution was seen as fulfilling a number of purposes 
including satisfying the sexual needs of German soldiers and thereby avoiding their contact with 'impure' forced labourers in occupied countries, as well as serving as a means of 'therapy' for homosexual male prisoners ${ }^{5}$ in an endeavour to convert them to heterosexuality. Lengyel ${ }^{6}$ suggests that prostitutes were provided as an acceptable sexual outlet for SS and other camp guards who were continuously exposed to vast numbers of naked women paraded before them in camps. Access to prostitutes was also used as an incentive for increased productivity amongst both senior camp personnel and privileged prisoners in camps. A network of statecontrolled brothels was established across Europe including civil and military brothels, as well as those for forced labourers and those in concentration camps. The most beautiful women went to the SS brothel, the less beautiful ones to the soldier's brothels. The rest ended up in the prisoner's brothels. ${ }^{7}$

\section{Sexual Brutality in Towns and Villages}

Sexuality extended into brutality in many settings. Numerous reports show that corpses of thousands of Jews were dumped into pits, which they had been made to dig, after which they were lined up beside them and killed with guns. German officers and their local allies pulled gold teeth out of mouths, before or after, murdering their victims. Babies were thrown into the air and used for target practice. Jewish women were raped before being murdered. Sometimes, as in Czestochowa, Poland, police forced thousands of half-naked men and women to assemble in a square where they were beaten. Young girls were taken into the synagogue, forced to undress, sexually assaulted and tortured. ${ }^{8}$ The massacre in the Greek town of Distomo also reflects the sexually directed aspects of Nazi cruelty. ${ }^{9}$ Just outside the village, SS troops were attacked by partisans. They returned to the village and spent the next few hours killing the population viciously. As Nicholas reports,

Pregnant women were eviscerated with bayonets and their intestines wrapped around their necks. People were decapitated and children's heads crushed. Houses were burned with all the occupants inside. Women and little girls were raped and then executed. $^{10}$

Children too, did not escape sexual brutality. In a French village, the SS tied the smallest children, boys and girls, to the chairs in the schoolroom. They told them:

to suck the soldiers' organs like their mothers' breasts. Then when the soldiers have had their way, the children are told to imagine it as milk and swallow happily, and their teachers are to make sure they do not cry as they swallow. ${ }^{11}$ 
The Einsatzgruppen were particularly distinguished by their brutality including shooting pregnant women in the belly before throwing them into burial pits, and conducting body searches of sex organs and anuses looking for valuables. ${ }^{12}$ Others might hurl a fist into the belly of a pregnant woman and throw her alive into the grave. $^{13}$

\section{Sexual Brutality in Ghettos}

Ghettos provided little escape from Nazi sexual brutality. In the Kovno ghetto, Tornbaum, a 'typical German gendarme' forced women to undress, so that he could conduct gynaecological examinations on them (looking for hidden valuables) while at the same time beating them severely. ${ }^{14}$ Internal examinations of women in ghettos are reported by others. ${ }^{15}$ In Hungary, prior to deportation, some women had electric wires inserted into their uterus in front of their family as part of the search for hidden valuables. ${ }^{16}$ Similarly Dr Edith Kramer reports that women in the Lodz ghetto were offered a chance to work in Poland. Before going they were required to bathe: 'This provided a good chance for the SS men to beat the naked girls with whips. ${ }^{, 17}$ Martin Gray ${ }^{18}$ reports that in the Warsaw ghetto, 'he'd seen them dash out the brains of newborn babies against the walls, rip open the bellies of pregnant women, and throw casualties into the flames. ${ }^{, 19}$

\section{Sexual Brutality in Prisons}

Those in prison were even more readily exposed to sexual brutality: Käthe Baronowitz, arrested as a communist, reported that

The cruelties and perversities of the interrogation can hardly be described. [She] had to undress completely. A howling pack goaded on by alcohol surrounded her. They stuck pens in her vagina and paper flags, which they burned so that they could gloat over the tortured woman's screams of pain. They called her a 'Jew whore' as they tormented her. ${ }^{20}$

Jadwiga Dzido at the Nuremberg Doctors trial reported being beaten while naked by the Gestapo in Lublin ${ }^{21}$ and Dr Edith Kramer, imprisoned in Berlin, watched the Gestapo training police dogs to jump at fluttering skirts fastened to wooden rods. ${ }^{22}$

Klaus Barbie is perhaps best known amongst sexually brutal prison commanders. Paris wrote,

Women were always tortured naked, to the deep enjoyment of the torturers. Barbie kept two German shepherd dogs. One was trained to lunge and bite. The other was trained to mount naked women who had first been ordered on their hands and knees. A 
humiliation that cut deeper than the whip, than having one's fingernails pulled. ${ }^{23}$

Father Bonaventura Boudet who was interrogated by the Gestapo in the prison where Barbie was based, reported that fingers and toes were cut off with kitchen knives, women's breasts were severed and their nipples torn off, limbs were burned and severed from the body. ${ }^{24}$ On September 18, 1943 Klaus Barbie was personally cited by Himmler and on November 9, 1943, he was awarded the Iron Cross, First Class, with sword. ${ }^{25}$

\section{Sexual Brutality in Concentration Camps}

While humiliation, nudity and voyeurism were common in the camps, more extreme forms of sexual brutality occurred. The Ukrainian Ivan Demaniuk in Treblinka

stabbed the women's naked thighs and genitals with a sword before they entered the gas chambers and also raped young women and girls. ${ }^{26}$

In Treblinka, the camp commander had a dog trained to attack a man's private parts. The dog was called 'Man' and the Jews 'Dogs': He would attack when given the order 'Look, Man, that dog isn't working'. ${ }^{27}$

SS officer Tauber, in Auschwitz, was known for his sadistic acts towards women. $\mathrm{He}$

brought a thousand women out into the snow, lined them up, entirely naked, in the freezing air, then, moving along the ranks, lifted their breasts with the tip of his whip. Those whose breasts sagged went to the left, those whose breasts remained firm went to the right and were spared a little longer. ${ }^{28}$

\section{Sexual Brutality Perpetrated by Women}

Men were not the only perpetrators of sexual brutality. Some women also achieved notoriety in this respect. In Auschwitz,

Irma Griese had selected a handsome Georgian man to become her lover. When he refused she beat his true love, a slim, Polish woman, brutally in front of him while she was naked. 'She was in a dreadful state. Red welts extended across her face and across her chest. The sadistic SS had spared not even her face...I never saw the handsome Georgian again. The beautiful beast had him shot. The girl? Griese had had her sent to the Auschwitz brothel. ${ }^{29}$ 


\section{Sexual Brutality towards Homosexuals}

The most grievous tortures of a sexually sadistic nature were imposed on homosexual prisoners in concentration camps. Heger describes the torture to death of a homosexual man:

He was stripped naked and his hands tied to a hook in a wall so that he could not touch the ground with his feet. First he was tickled with goose feathers on the soles of his feet, the armpits, between the legs and other parts of his naked body. Then the SS brought two metal bowls, one filled with cold water one with hot. These bowls were placed between his legs alternatively so that his testicles hung in the hot, then cold water. This continued until the victim lost consciousness screaming in agony. A bucket of cold water was thrown over him to bring him around and then the torture stared again, 'this time with bits of skin now hanging visibly down from the victim's scalded scrotum'. Then they shoved a broom handle deep into his anus - his body jerked and tore at the chains. Eventually they cut him down. One of the SS brought a wooden chair down on the victim's head with all his force, killing him. ${ }^{30}$

\section{Sexual Arousal through Brutality}

Survivor memoirs report sexual arousal and satisfaction being gained through acts of brutality. Irma Griese, in Auschwitz, experienced sexual arousal while observing breast surgery.

From that day on she went around in camp, her bejewelled whip poised, picked out the most beautiful young women and slashed their breasts open with the braided wire end of her whip. Subsequently those breasts got infected by the lice and dirt, which invaded every nook and corner of the camp. They had to be cut open if the patient was to be saved. Irma Greze invariably arrives to watch the operation, kicking the victim if her screams interfered with her pleasure and giving herself completely to the orgiastic spasms, which shook her entire body and made saliva run down from the corner of her mouth. ${ }^{31}$

Similarly, Klauss Scheurenberg reports that in Eichmann's headquarters in Wulkow, the commandant gained sexual pleasure from watching beatings of men. As he reports, 'He sent some of us to Sachsenhausen to be gassed; he shot some and he beat some to death with a chain. At some point in the beatings, he always reached a climax and his pants got wet. ${ }^{32}$ 
Sexual gratification was also obtained from cruelty to homosexuals. As Heger reports, the camp commander stood by and watched as homosexuals were beaten:

At each stroke his eyes lit up and after a few strokes his whole face was red with excitement. He buried his hands in his trouser pockets and could clearly be seen to masturbate, quite unperturbed by our presence... I myself witnessed on more than thirty occasions how this camp commander got sexual satisfaction from watching the lashings inflicted on the 'horse' and the perverted lust with which he followed each stroke and the screams of the victim. ${ }^{33}$

\section{How could They Do It? Why did They Do It?}

How could the Nazis perpetrate such sexual brutality? The effective Nazi propaganda campaign that dehumanized Jews to the point of being considered as 'vermin,' 'subhumans,' or 'life unworthy of life' probably made it psychologically possible for Germans who endorsed Nazi ideology to perpetrate such horrific acts. Underlying such images was an overwhelming fear of 'contamination,' or of the threat supposedly imposed by Jews. Although reduced to the lowest level of poverty and humanity, and comprising less than $1 \%$ of German society, Jews were depicted as a global threat. They were seen as promoting an international conspiracy that was the driving force behind the Allied 'enemies' of Germany, and were depicted as responsible for manipulating the world's, and Germany's, finances. Fear and hatred of Jews, combined with the Nazis newfound personal power over others and their desire for a new powerful Germany and Aryan race, combined to mobilize and justify such brutal actions.

The real villains, particularly with regard to sexual behaviours, were clearly Germans rather than Jews.

\section{Notes}

${ }^{1}$ A. Hitler, Mein Kampf, Hurst and Blackett, London 1939, pp. 160-162.

${ }^{2}$ M. Kater, Doctors under Hitler, The University of North Carolina Press, Chapel Hill, 1989, pp. 179-181; M. Burleigh and W. Wipperman, The Racial State: Germany 1933-194, Cambridge University Press, Cambridge, 1991, p. 37.

${ }^{3}$ V. Harlan (dir), Jud Süß, Terra-Filmkunst GmbH, 1934.

${ }^{4}$ D. Herzog, 'Hubris and Hypocrisy, Incitement and Disavowal: Sexuality and German Fascism', Journal of the History of Sexuality, 11/1/2, 2002, pp. 3-21.

${ }^{5}$ H.P. Bleuel, Sex and Society in Nazi Germany, J.B. Lipincott Company, 1971, p. 225, R.J. Lifton, The Nazi Doctors: Medical Killing and the Psychology of Genocide, Basic Books, Inc, New York, 1986, pp. 270-271. 
${ }^{6}$ O. Lengyel, Five Chimneys: A Woman Survivor's True Story of Auschwitz, First Academy Chicago, 1995, p. 195.

7 R. Sommer, Das Kz-Bordell: Sexual Forced Labor in National Socialist Concentration Camps. Paderborn Schoningh Verlag, 2009, p. 492.

${ }^{8}$ L. Dawidowicz, The War against the Jews 1933-1945, Bantam Books, New York, 1975, p. 270.

${ }^{9}$ L.H. Nicholas, Cruel World: The Children of Europe in the Nazi Web, Vintage Books, New York, 2006, p. 430.

${ }^{10}$ Ibid., p. 430.

${ }^{11}$ D.A. Rose, Hiding Place, Simon and Schuster, New York, 2000, pp. 320-322.

${ }^{12}$ R. Rhodes, Masters of Death: The SS Einsatzgruppen and the Invention of the Holocaust, Alfred A. Knopf, New York, 2002, pp. 185-186; E. Klee, W. Dressen and V. Reiss (eds), The Good Old Days: The Holocaust as Seen by Its Perpetrators and Bystanders, Old Saybrook, Konecky and Konecky, Connecticut, 1991, p. 179.

${ }^{13}$ R. Hilberg, The Destruction of the European Jews, Holmes and Meier, New York, 1985, p. 146.

${ }^{14}$ A. Tory, Surviving the Holocaust: The Kovno Ghetto Diary, Harvard University Press, Cambridge, MA, 1990, p. 403.

${ }^{15}$ A. Porter, Kasztner's Train: The True Story of Rezsö Kasztner, Unknown Hero of the Holocaust, Douglas \& McIntyre, Vancouver, 2007, pp. 156-158; S. Littman, War Criminal on Trial: Rauca of Kaunas, Key Porter Books, Toronto, 1993, p. 102; M. Berg, The Diary of Mary Berg, Oneworld, Oxford, 1945, Toronto 2007, p. 37.

${ }^{16}$ Porter, op. cit., p. 170.

${ }^{17}$ R.A. Ritvo and D.M. Plotki, Sisters in Sorrow: Voices of Care in the Holocaust, Texas A \& M University Press, 1998, p. 134.

${ }^{18}$ M. Gray and M. Gallo, For Those I Loved, Little, Brown and Company, Boston, 1971, p. 204.

${ }^{19}$ Ibid.

${ }^{20}$ M.A. Kaplan, Between Dignity and Despair: Jewish Life in Nazi Germany, Oxford University Press, New York, 1998, pp. 19-20.

${ }^{21}$ V. Spitz, Doctors from Hell: The Horrific Accounts of Nazi Experiments on Humans, Sentient Publications, Boulder, 2005, p. 146.

${ }^{22}$ Ritvo and Plotki, op. cit., p. 141.

${ }^{23}$ J. Miller, One by One by One: Facing the Holocaust, Simon and Schuster, New York, 1990, p. 123.

${ }^{24}$ T. Bower, Klaus Barbie: Butcher of Lyon, Corgi Books, London, 1984, p. 75.

25 E. Paris, Unhealed Wounds:France and the Klaus Barbie Affair, Methuen, Toronto, 1985, p. 94.

${ }^{26}$ E. Rozenberg, Testimony, Jerusalem, p. 6.

${ }^{27}$ J.F. Steiner, Treblinka, Simon and Schuster, New York, 1967, p. 166. 
${ }^{28}$ F. Fenelon, Playing for Time, Berkley Books, New York, 1977, p. 173.

${ }^{29}$ O. Lengyel, Five Chimneys: A Woman Survivor's True Story of Auschwitz, pp. 201-203.

${ }^{30}$ H. Heger, The Men with the Pink Triangle, Alyson Books, New York, 1980, p. 84.

${ }^{31}$ G. Perl, I Was a Doctor in Auschwitz, Reprint edition 2007, Ayer Company Publishers, North Stratford, NH, 1948, pp. 61-62.

32 J. Steinhoff, P. Pechel and D. Showalter, Voices from the Third Reich: An Oral History, Da Capo Press, Washington, 1989, p. 332.

${ }^{33}$ Heger, op. cit., pp. 53-55.

\section{Bibliography}

Berg, M., The Diary of Mary Berg. Oneworld, Oxford, 1945, 2007.

Bleuel, H.P., Sex and Society in Nazi Germany. J.B. Lipincott Company, Philadelphia, 1971.

Bower, T., Klaus Barbie: Butcher of Lyons. Corgi Books, London, 1984.

Burleigh, M. and Wipperman, W., The Racial State: Germany, 1933-1945. Cambridge University Press, Cambridge, 1991.

Dawidowicz, L., The War against the Jews, 1933-1945. Bantam Books, New York, 1975.

Fenelon, F., Playing for Time. Berkley Books, New York, 1977.

Gray, M. and Gallo, M., For Those I Loved. Little, Brown and Company, Boston, 1971.

Harlan, V. (dir) Jud Süß. 197 minutes. Germany: Terra-Filmkunst GmbH, 1934.

Heger, H., The Men with the Pink Triangle. Alyson Books, New York, 1980.

Herzog, D., Hubris and Hypocrisy, Incitement and Disavowal: Sexuality and German Fascism. Journal of the History of Sexuality. 2002.

Hilberg, R., The Destruction of the European Jews. Holmes and Meier, New York, 1985. 
Hitler, A., Mein Kampf. Hurst and Blackett, London, 1939.

Kaplan, M.A., Between Dignity and Despair: Jewish Life in Nazi Germany. Oxford University Press, New York, 1998.

Kater, M., Doctors under Hitler. The University of North Carolina Press, Chapel Hill, 1989.

Klee, E., Dressen, W. and Reiss, V. (eds), The Good Old Days: The Holocaust as Seen by Its Perpetrators and Bystanders. Konecky and Konecky, Old Saybrook, Connecticut, 1991.

Lengyel, O., Five Chimneys: A Woman Survivor's True Story of Auschwitz. ZiffDavis Publishing Company, Chicago, 1947.

Lifton, R.J., The Nazi Doctors: Medical Killing and the Psychology of Genocide. Basic Books, Inc, New York,1986.

Littman, S., War Criminal on Trial: Rauca of Kaunas. Key Porter Books, Toronto, 1993.

Miller, J., One by One by One: Facing the Holocaust. Simon and Schuster, New York 1990.

Nicholas, L.H., Cruel World: The Children of Europe in the Nazi Web. Vintage Books, New York, 2006.

Paris, E., Unhealed Wounds: France and the Klaus Barbie Affair. Methuen, Toronto, 1985.

Perl, G., I Was a Doctor in Auschwitz. Reprint edition 2007 ed., Ayer Company Publishers, North Stratford, NH, 1948.

Porter, A., Kasztner's Train: The True Story of Rezsö Kasztner, Unknown Hero of the Holocaust. Douglas \& McIntyre, Vancouver, 2007.

Rhodes, R., Masters of Death: The SS Einsatzgruppen and the Invention of the Holocaust. Alfred A. Knopf, New York, 2002.

Ritvo, R A. and Plotkin, D.M., Sisters in Sorrow: Voices of Care in the Holocaust. Texas A \& M University Press, College Station, 1998. 
Rose, D.A., Hiding Places. Simon and Schuster, New York, 2000.

Rozenberg, E., Testimony, YVA, 0-3/4039. Yad Vashem Jerusalem.

Sommer:, R., Das Kz-Bordell - Concentration Camp Bordello: Sexual Forced Labor in National Socialist Concentration Camps. Schoningh Verlag, Paderborn, 2009.

Spitz, V., Doctors from Hell: The Horrific Accounts of Nazi Experiments on Humans. Sentient Publications, Boulder, 2005.

Steiner, J.F., Treblinka. Simon and Schuster, New York 1967.

Steinhoff, J., Pechel, P. and Showalter, D., Voices from the Third Reich: An Oral History. Da Capo Press, Washington, 1989.

Tory, A., Surviving the Holocaust: The Kovno Ghetto Diary. Cambridge Harvard University Press, Massachusetts, 1990.

Beverley Chalmers (DSc(Med);PhD) is an Adjunct Full Professor in the Department of Obstetrics and Gynaecology at the University of Ottawa, and an Affiliate Investigator in the Ottawa Health Research Unit, Ontario, Canada. This article is based on contributions to the degree of D. Litt et Phil. (History) at the University of South Africa under the supervision of Profs Tilman Dedering (Dept of History) and Anthony Court (Primedia Holocaust \& Genocide Unit, School for Graduate Studies). 



\title{
The State Villainy in Orwell's 1984
}

\author{
Cumhur Yllmaz Madran
}

\begin{abstract}
This chapter intends to elucidate George Orwell's vision of totalitarian villainy in his dystopic novel 1984, which shows socio-political oppression. Orwell's novel reflects the villainy, which is created by the totalitarian regimes, which employ insidious mechanisms and power to exert domination and oppression over population. Accordingly, George Orwell's novel provides a multidimensional theoretical and political perspective on the villainy in contemporary totalitarian societies. This totalitarian society demonstrates its villainy by employing terror, surveillance to exert its power over the public. Every aspect of life from everyday life to sexuality is controlled by the villainy of the state. Through the intricate techniques of political villainy and repression, the state controls public and private spheres of the individuals. In order to reflect the villainy, which is used by the state power and terror, Orwell tries to prove the dichotomy concerning instrumental rationality in that it can be used in a positive and negative way for social progress or oppression. Orwell's novel provides critical perspectives on the villainy of the totalitarian regimes. This chapter aims to shed light on the state villainy in totalitarian regimes in the light of Hannah Arendt's The Origins of Totalitarianism.
\end{abstract}

Key Words: Villainy, totalitarianism, 1984, oppression, Big Brother, intricate mechanisms.

$* * * * *$

The concept of totalitarianism is commonly used to refer to the regimes in which the entire population is in the service and support of the state and its political ideology which controls nearly every aspect of the individual's life and is more repressive than other types of regimes. In order to maintain its existence, the state makes use of every tool from physical power to some psychological techniques in order to keep the public under its control, power and oppression such as secret police, manipulation methods through mass media. The totalitarian regimes employ insidious mechanisms and power to exert domination and oppression over population. The totalitarian society demonstrates its villainy by employing terror and surveillance. Every aspect of life from everyday life to sexuality is controlled by the villainy of the state. All requirements of the individual are subordinated to the state for its existence. Through the intricate techniques of political villainy and repression, the state controls public and private spheres of the individuals.

The concept of totalitarianism was made popular by Hannah Arendt in her 1951 book The Origins of Totalitarianism. This chapter intends to elucidate 
George Orwell's vision of totalitarian villainy in his dystopic novel 1984, which shows socio-political oppression in the light of Hannah Arendt's The Origins of Totalitarianism. Hannah Arendt in her book made a theoretical analysis of the totalitarian governments. Orwell's novel reflects the stages Hannah Arendt stated in her book about the construction of a totalitarian government: one-party state, the cult of the leader, absolute power, the secret police and censorship, the executions, and obliteration of man's identity. Accordingly, George Orwell's novel provides a multidimensional theoretical and political perspective on the villainy in contemporary totalitarian societies. In order to reflect the villainy, which is used by the state power and terror, Orwell tries to prove the dichotomy concerning instrumental rationality in that it can be used in a positive and negative way for social progress or oppression. Orwell's novel provides critical perspectives on the villainy of the totalitarian regimes. As pointed out by Miskelly, George Orwell is 'the best known and most influential modern critic of authoritarianism and totalitarianism. ${ }^{1}$

1984 is a harsh criticism of totalitarianism. All totalitarian regimes are oneparty state and have a god-like leader who legitimizes the regime. In a totalitarian regime, there is a single one who leads the government, and there is a single party. The totalitarian regime in Orwell's 1984 fits this model with its single party and omnipotent leader, Big Brother:

At the apex of the pyramid comes Big Brother. Big Brother is infallible and all-powerful. Every success, every achievement, every victory, every scientific discovery, all knowledge, all wisdom, all happiness, all virtue, are held to issue directly from his leadership and inspiration. Nobody has ever seen Big Brother. $\mathrm{He}$ is a face on the hoardings, a voice on the screen. We may be reasonably sure that he will never die, and there is already considerable uncertainty as to when he was born. Big Brother is the guise in which the party chooses to exhibit itself to the world. His function is to act as a focusing point for love, fear, and reverence, emotions which are more easily felt toward an individual than an organization. ${ }^{2}$

Big Brother has his own particular aura, which heightens him to a category of a pharaoh. The existence of this ultimate authority is made the public felt everywhere. His posters with the enormous face gazing from the wall are so contrived that people feel they are being followed wherever they go or whenever they move. Under the poster are the words: 'BIG BROTHER IS WATCHING YOU! ${ }^{3} \mathrm{He}$ is not only omnipotent but also omnipresent: When Winston Smith, who is a member of the Outer party from Oceania, and who works at the Ministry of Truth, takes a twenty-five-cent piece out of his pocket: 
There, too, in tiny clear lettering, the same slogans were inscribed, and on the other face of the coin the head of Big Brother. Even from the coin the eyes pursued you. On coins, on stamps, on the covers of books, on banners, on posters, and on the wrapping of a cigarette packet-everywhere. Always the eyes watching you and the voice enveloping you. Asleep or awake, working or eating, indoors or out of doors, in bath or in bed-no escape. Nothing was your own except the few cubic centimetres inside your skull. ${ }^{4}$

Big Brother's ultimate authority combined with the state control through Telescreen, Thought Police, Newspeak, watching, spying abolishes privacy in Oceania. There is no way of knowing whether you are being watched at any given moment. They have to live from habit that becomes instinct-in the assumption that every sound they make is overheard, and every moment scrutinized. It is terribly dangerous to let someone's thoughts wander when he/she is in any public place or within range of a telescreen. The smallest thing can give them away. A nervous tic, an unconscious look of anxiety, a habit of muttering to themselves-anything that carries with it the suggestion of abnormality, of having something to hide. In any case, to wear an improper expression on someone's face is itself a punishable offence. It is called face crime. 'Whenever it wishes to, the party can invade the privacy of the inmost mind and heart. ${ }^{5}$

Hannah Arendt remarks that 'it is in the very nature of totalitarian regimes to demand unlimited power. Such power can only be secured if literally all men, without a single exception, are reliably dominated in every aspect of their life. ${ }^{6}$ Big Brother's totalitarian government's aim is not only power, but absolute power as well:

The party seeks power entirely for its own sake. We are not interested in the good of others; we are interested solely in power. Not wealth or luxury or long life or happiness; only power, pure power. ... power is not a means; it is an end. One does not establish a dictatorship in order to safeguard a revolution; one makes the revolution in order to establish the dictatorship. The object of persecution is persecution. The object of torture is torture. The object of power is power. ${ }^{7}$

Orwell examines the effects of this absolute power on individual consciousness in 1984. This absolute power is perpetuated through the elimination of individual rights, through violence, oppression, cruelty, and through some manipulative tools of language and media. 
The absolute power includes all the spheres of life. The ones who are opposed to the ideology of the party are either punished or wiped out. The espionage, the spying, the betrayals, the arrests, the tortures, the executions, the disappearances are the most commonly seen techniques of keeping the public under control. It is the world of the terror. People are vaporised, and they disappear or vanish all of sudden. The names of the people who are vaporised are considered never to have existed. Their records are altered, and after a while they are forgotten, and nobody remembers whether such a man has existed or not. They cease to exist, and they have never existed. It is the period of great purges. People are forced to commit suicide. As pointed out by Hannah Arendt, 'what totalitarian ideologies therefore aim at is not the transformation of the outside world or the revolutionising transmutation of society, but the transformation of human nature itself ${ }^{8}{ }^{8}$ Totalitarianism's main target is to destroy every trace of human dignity. They do not merely destroy their enemies, they change and reshape them. They try to kill their humanitarian feelings and emotions. O'Brien, who is a member of the Inner party who works for Thought Police, clearly expresses to Winston what they would like to do: 'Never again will you be capable of love, or friendship, or joy, of living, or laughter, or curiosity, or courage, or integrity. You will be hollow. We shall squeeze you empty, and then we shall fill you with ourselves.' 9

Arendt makes an analysis of the three steps of destroying man's consciousness and identity by a totalitarian state in order to secure and keep its absolute power eternally. According to Arendt, "the first essential step on the way to total domination is to kill the juridical person in man. ...The aim is to destroy the civil rights of the whole population, who ultimately become just as outlawed in their own country as the stateless and homeless. The destruction of a man's rights, the killing of the juridical person in him, is a prerequisite for dominating him entirely. ${ }^{10}$ In the totalitarian state Oceania, men and women are dehumanised and are reduced to the condition of mere, undifferentiated deformed not only physically but also psychologically in the torturing chambers, which are, in an ironical way, found in the Ministry of Love. Nobody knows what happens inside the Ministry of Love in Oceania, but it is 'possible to guess: tortures, drugs, delicate instruments that registered your nervous reactions, gradual wearing-down by sleeplessness and solitude and persistent questioning. Facts, at any rate, could not be kept hidden. They could be tracked down by inquiry, they could be squeezed out of you by torture. ${ }^{11}$ Ironically, it is possible to see the inscription of freedom is slavery in on all the buildings of the Ministries.

According to Arendt, 'the next decisive step in the preparation of living corpses is the murder of the moral person in man. This is done in the main by making martyrdom for the first time in history, impossible. They have corrupted all human solidarity. ${ }^{12}$ In Orwellian Oceania, there is no place for privacy, love, friendship, and loyalty. Everybody is afraid of the other, and nobody has any confidence in the other people. People lead a life of terror, and they are watched night and day for 
symptoms of unorthodoxy. The public of Oceania is frightened of other people around themselves, their own children and even themselves. People hate each other, and this hatred spreads like an epidemic. They are so alienated and isolated that everyone is suspicious of the other. People do not talk to each other about their jobs and themselves. Winston does not know who the other people are, and he does not even know the names of the people who work together with him, though he daily sees them hurrying to and fro in the corridors.

Man's nature is abolished, and destroyed morally in order to obtain and maintain the absolute power. Spying, overhearing, watching, conspirations, plots and sabotaging are the moral values of the Oceania people. Many innocent people are denounced by the closest friends, neighbours, or even their own parents or children. Children are taught to be always watchful of the adults and to denounce them when they are suspicious of their activities of any unorthodoxy. The decomposition, disorganisation, or deterioration of the moral principles and virtues is the second important step in maintaining ultimate power by the totalitarian state in Oceania. Totalitarian villainy achieves its most terrible triumph when it succeeds in cutting the moral person off from the rest of the society. To the end of the novel, when Winston has been tortured by O'Brien, Winston shouts frantically over and over: 'Do it Julia! Not me! Julia! I don't care what you do her. Tear her face off, strip her to the bones. Not me! Julia! Not me! ${ }^{13}$ When Julia and Winston meet by chance in the park, it strikes Winston at once that she has changed in some ill defined-way. They almost pass one another without a sign. Julia does not talk. She tries to get rid of him. Upon Winston's insistence, she halts: 'He put his arm round her waist. ...His flesh froze with horror at the thought of it. She made no response whatever to the clasp of his arm. ...He knew now what had changed in her. ... 'I betrayed you,' she said badly. 'I betrayed you,' he said. ${ }^{14}$ Both of them think that there is no other way of saving themselves. All they care about is themselves. Moral person is killed and, people are turned into living corpses, man's unique identity and the differentiation of the individual are obliterated. As Arendt pointed out:

In a sterile form such individuality can be preserved through a persistent stoicism, and it is certain that many men under totalitarian rule have taken and are each day still taking refugee in this absolute isolation of a personality without rights or conscience. There is no doubt that this part of the human person, precisely because it depends so essentially on nature and on forces that cannot be controlled by the will, is the hardest to destroy (and when destroyed is most easily repaired). ${ }^{15}$

This leads to the third step on the way to villainous totalitarianism: 'For to destroy individuality is to destroy spontaneity, man's power to begin something 
new out of his own resources, something that cannot be explained on the basis of reactions to environment and events. ${ }^{16}$ Man is utterly turned into an animal-like creature that reacts only to the conditioned reflexes. People are like puppets whose ropes are in someone else's hands. They serve no useful purpose. Man is reduced to such a stage in which he is no longer needed and is necessary. According to Arendt, 'totalitarianism strives not toward despotic rule over men, but toward a system in which men are superfluous. Total power can be achieved and safeguarded only in a world of conditioned reflexes, of marionettes without the slightest trace of spontaneity. Precisely because man's resources are so great, he can be fully dominated only when he becomes a specimen of the-animal species man. Therefore, character is a threat...individuality, anything indeed that distinguishes one man from another, is intolerable. As long as all men have not been made equally superfluous ...the ideal of totalitarian domination has not been achieved. ${ }^{17}$ When O'Brien, who is the guardian, protector and tormentor of the totalitarian regime in Oceania, has started the process of making Winston perfect, he is certain that reality exists in the human mind and nowhere else. Nothing exists except through human consciousness. Outside man, there is nothing. His ultimate aim is neither to extract Winston's confession nor to punish him. His aim is not to destroy Winston but to cure and to make Winston sane and to change him. There are three main stages in Winston's reintegration according to O'Brien: There is learning, there is understanding, and there is acceptance. ${ }^{18}$ Step by step, Winston is reshaped. According to O'Brien, man is only a speck of dust. Man is tiny and helpless. They can easily be moulded: 'We create human nature. Men are infinitely malleable. They are helpless, like the animal' ${ }^{19}$ and, ironically, asks Winston: 'Do you consider yourself a man?' ${ }^{20}$ Then, O'Brien answers his own question: 'You are rotting away, ... you are falling to pieces. What are you? A bag of filth. Now turn round and look into that mirror again. Do you see that thing facing you? That is the last man. If you are human, that is humanity. ${ }^{, 21}$ O'Brien's ultimate aim is to destroy every trace of human dignity in Winston and to transform his nature itself. Thus, Winston Smith is moulded, reshaped, and destroyed by the totalitarian state villainy in Oceania in line with Hannah Arendt's thesis of the totalitarian domination: the murder of the juridical, moral and spontaneous person. $\mathrm{He}$ is 'crushed by the state, tortured to the point that he ceases to have any unique consciousness and becomes a shell of a man before his execution. ${ }^{22}$

In 1984, George Orwell attacks totalitarian regimes which control all aspects of life through the state villainy. According to George Orwell, totalitarian state villainy is a basic evil of man's modern world. He warns people against the possibilities of the establishments of totalitarian governments depending upon his own experiences of Nazis and Soviets. He provides an insight into what we should avoid. He aims at showing what can happen to man in the future if they do not take precautions against totalitarian regimes. 'Totalitarianism, if not fought against, could triumph everywhere. ${ }^{23}$ This phenomenon is going to be world-wide. The 
totalitarian governments are established only for the sake of having and keeping absolute power. There have always been people who have run after absolute power and struggled for it, and there will always be such kind of people in the future. If political, social and economic events of modern world everywhere become in silent conspiracy with totalitarian state villainy, man will be superfluous.

\section{Notes}

${ }^{1}$ M. Miskelly and J. Noce, Political Theories for Students, The Gale Group and Thomson Learning, New York, 2002, p. 382.

${ }^{2}$ G. Orwell, 1984, Signet Classics, New York, 1961, p. 208.

${ }^{3}$ Ibid., p. 2.

${ }^{4}$ Ibid., p. 27.

${ }^{5}$ R.J. Voorhees, The Paradox of George Orwell, Purdue University, Lafayette, 1961, p. 81.

${ }^{6} \mathrm{H}$. Arendt, The Origins of Totalitarianism, A Harvest Book Harcourt, San Diego, Inc., 1976, p. 456.

${ }^{7}$ Ibid., p. 263.

${ }^{8}$ Arendt, op. cit., p. 458.

${ }^{9}$ Orwell, op. cit., p. 256.

${ }^{10}$ Arendt, op. cit., pp. $447 \& 451$.

${ }^{11}$. Orwell, op. cit., p. 167.

${ }^{12}$ Arendt, op. cit., p. 451.

${ }^{13}$ Ibid., p. 286.

${ }^{14}$ Ibid., pp. 291-292.

${ }^{15}$ Arendt, op. cit., p. 453.

${ }^{16}$ Ibid., p. 455.

${ }^{17}$ Ibid., p. 457.

${ }^{18}$ Orwell, op. cit., p. 260.

${ }^{19}$ Ibid., p. 269.

${ }^{20}$ Ibid., p. 270.

${ }^{21}$ Ibid., p. 272.

${ }^{22}$ D. Weksberg, The Methods of Totalitarianism in George Orwell's 1984, Duke, Duke University, 2004, p. 1.

${ }^{23}$ G. Orwell, 'Letter to Francis A. Henson - 16 June 1949', Twentieth Century Literary Criticism, Vol.15, Detroit, Gale Research Company, 1985, p. 301.

\section{Bibliography}

Arendt, H., The Origins of Totalitarianism. A Harvest Book Harcourt, Inc., San Diego, 1976. 
Miskelly, M. and Noce, J., Political Theories for Students. The Gale Group and Thomson Learning, New York, 2002.

Orwell, G., 1984. Signet Classics, New York, 1961.

, 'Letter to Francis A. Henson - 16 June 1949'. Twentieth Century Literary Criticism. Vol.15, Gale Research Company, Detroit, 1985.

Voorhees, R.J., The Paradox of George Orwell. Purdue University, Lafayette, 1961.

Cumhur Yılmaz Madran was born in Bozdoğan, Aydın on October 29, 1967. He received his B.A., and M. A. in English Literature from Atatürk University. He completed his Ph.D at METU in 2004. Since then, he has been working as an Assistant Prof. Dr. in the Department of Western Languages and Literatures at Pamukkale University. 